
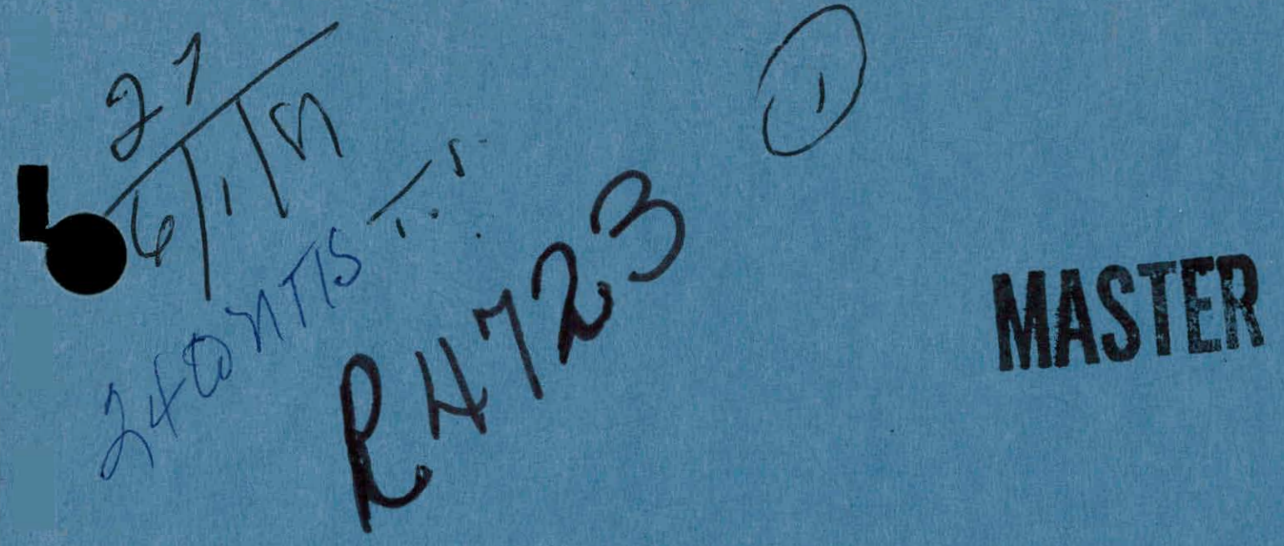

DOE/NV/00597-5

Advanced Energy Systems Division

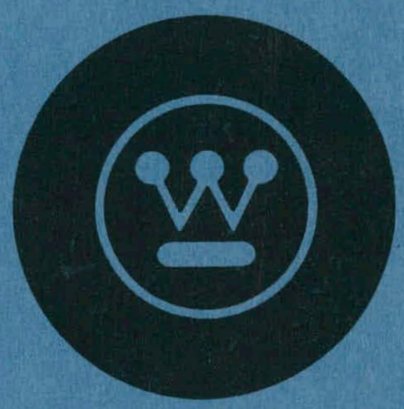

Spent Fuel Dry Storage Technology Development:

THERMAL EVALUATION OF ISOLATED

DRYWELLS CONTAINING SPENT FUEL

(1KW PWR Spent Fuel Assembly)

R. Unterzuber

J.B. Wright

Prepared For

THE UNITED STATES DEPARTMENT OF ENERGY

Contract No. DE-AC08-76NVOO597

SEPTEMBER 1980

Westinghouse Electric Corporation Advanced Energy Systems Division

P.O. Box 10864

Pittsburgh,Pennsylvania 15236 


\section{DISCLAIMER}

This report was prepared as an account of work sponsored by an agency of the United States Government. Neither the United States Government nor any agency Thereof, nor any of their employees, makes any warranty, express or implied, or assumes any legal liability or responsibility for the accuracy, completeness, or usefulness of any information, apparatus, product, or process disclosed, or represents that its use would not infringe privately owned rights. Reference herein to any specific commercial product, process, or service by trade name, trademark, manufacturer, or otherwise does not necessarily constitute or imply its endorsement, recommendation, or favoring by the United States Government or any agency thereof. The views and opinions of authors expressed herein do not necessarily state or reflect those of the United States Government or any agency thereof. 


\section{DISCLAIMER}

Portions of this document may be illegible in electronic image products. Images are produced from the best available original document. 


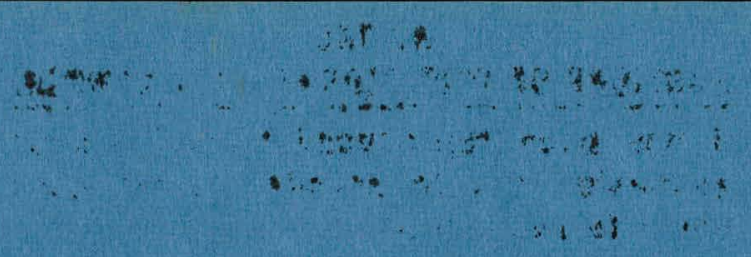

\section{DISCLAIMER}

This report was prepared as an account of work sponsored by the United States Government. Neither the United States nor the United States Department of Energy, nor any of their employees, makes any warranty, express or implied, or assumes any legal liability or responsibility for the accuracy, completeness, or usefulness of any information, apparatus, product, or process disclosed, or represents that its use would not infringe privately owned rights. Reference herein to any specific commercial product, process, or service by trade name, mark, manufacturer, or otherwise, does not necessarily constitute or imply its endorsement, recommendation, or favoring by the United States Government or any agency thereof. The views and opinions of authors expressed herein do not necessarily state or reflect those of the United States Government or any agency thertul.

Printed in the United States of America

Available from:

National Technical Information Service

U. S. Department of Commerce

5285 Port Royal Road

Springfield, Virginia 22161

Price: Printed Copy $\frac{\$ 17.00}{\text { Microfiche } \$ 3.50}$ 


\title{
Spent Fuel Dry Storage Technology Development: THERMAL EVALUATION OF ISOLATED DRYWELLS CONTAINING SPENT FUEL (1KW PWR Spent Fuel Assembly)
}

\author{
R. Unterzuber \\ J.B. Wright \\ Prepared For \\ THE UNITED STATES DEPARTMENT OF ENERGY \\ Under Contract No. DE-AC08-76NVOO597
}

\section{SEPTEMBER 1980}

WESTINGHOUSE ELECTRIC CORPORATION Advanced Energy Systems Division

P.O. Box 10864

Pittsburgh, Pennsylvania 15236

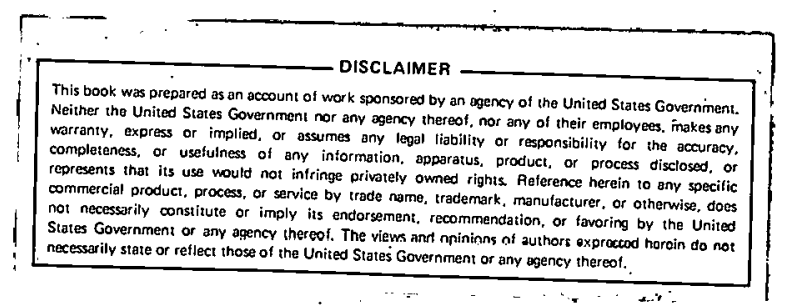




\section{ACKNOWLEDGEMENTS}

The authors wish to thank those who contributed to the development of this document.

C.A. Holder

W.L. Lundberg

P.S. Sherba 


\section{ABSTRACT}

A spent fuel Isolated Drywell Test was conducted at the Engine-Maintenance, Assembly and Disassembly (E-MAD) facility on the Nevada Test Site. Two pressurized water reactor spent fuel assemblies having a decay heat level of approximately $1.1 \mathrm{~kW}$ were encapsulated inside the E-MAD Hot Bay and placed in instrumented near-surface drywell storage. cells spaced 50 feet apart during January 1979 for thermal testing. Each fuel assembly was sealed inside a 14 inch diameter, 168 inch long stainless steel canister and attached to a concrete-filled, 20 inch diameter, 34 inch long, carbon steel shield plug. Each canister assembly was then placed in a carbon steel drywell liner which had been grouted into a hole drilled in the soil adjacent to E-MAD.

Instrumentation provided to measure canister, liner and soil temperatures consisted of thermocouples which were inserted into tubes on the outside of the canister and drywell liner and thermocouples which were attached to plastic pipe and grouted into holes in the soil. Temperatures from the two isolated drywells and the adjacent soil have been recorded throughout the 19 month Isolated Drywell Test. Canister and drywell liner temperatures reached their peak values $\left(254^{\circ} \mathrm{F}\right.$ and $203^{\circ} \mathrm{F}$, respectively) during August 1979. Thereafter, all temperatures decreased and showed a cycling pattern which responded to seasonal atmospheric temperature changes.

A computer model was utilized to predict the thermal response of the drywell. Computer predictions of the drywell temperatures and the temperatures of the surrounding soil are presented and show good agreement.with the test data. 
Section

Page No.

LIST OF TABLES

vi

LIST OF FIGURES

vii

1.0 INTRODUCTION

1.1 PURPOSE OF REPORT

1.2 ORGANIZATION

1.3 BACKGROUND

4.0 TEST HARDWARE DESCRIPTION

4.1 TEST ARRANGEMENT

4.2 DRYWELL LINER

4.2.1 Instrumentation

4.2.2 Liner Installation

4.3 CANISTER ASSEMBLY

4.3.1 Canister Body

4.3.2 Instrumentation

22

4.3.3 Canister Closure Lid

23

4.3.4 Shield Plug

23

4.3.5 Canister Assembly Installation

4.4 PWR SPENT FUEL ASSEMBLY

4.5 STORAGE SITE

4.6 INSTRUMENTATION WELLS

4.7 :DATA ACQUISITION SYSTEM

4.7.1 Thermocouples

39

4.7.2 Data Logger System 


\section{TABLE OF CONTENTS (Cont'd)}

Section

Page No:

4.8 DRYWELL CANISTER EMPLACEMENT EQUIPMENT

4.8.1 Transfer Shield

4.8.2 Drywell Shield Adapter

5.0 TEST OPERATIONS AND RESULTS 46

5.1 TEST OPERATIONS 46

5.1.1 Construction 46

5.1.2 Fuel Assembly Encapsulation. 46

5.1.3 Transfer to the Drywell 48

5.1 .4 Temperature Monitoring 49

5.1.5 Subsequent Repair Activities . 49

5.2 TEST RESULTS 51

5.3 ACCURACY OF TEST DATA 61

5.4 POST-ISOLATED DRYWELL TEST OBSERVATIONS 62

6.0 THERMAL ANALYSIS MUUEL 65

6.1 ANALYSIS PURPOSE AND METHOD 65

6.2 MODEL DESCRIPTION ' 65

6.2.1 Model Size and Boundary Conditions 65

6.2.2 Heat Transfer Mechanisms . 69

6.2.3 Material Properties 73

6.2.4 Fuel Assembly Heat Generation Rate 78

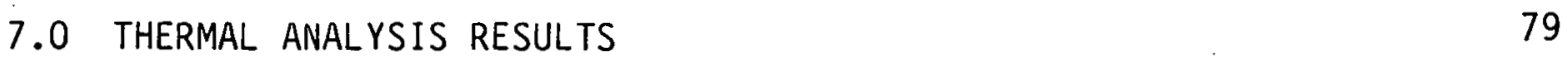

7.1 MODEL EVALUATION CRITERIA

$\begin{array}{ll}7.2 \text { MODEL/DATA COMPARISONS } & 79\end{array}$

7.2.1 Canister and Liner Axial Temperature 79

$$
\text { Profiles }
$$


TABLE OF CONTENTS (Cont'd)

Section

Page No.

7.2.2 Transient Canister, Liner, and Soil
Temperatures

81

8.0 REFERENCES

88

APPENDIX A

DRYWELL TEST HARDWARE AND INSTALLATION

89

APPENDIX B

ISOLATED DRYWELL TEST DATA

109

APPENDIX $C$

TEST DATA ILLUSTRATIONS

150

APPENDIX D

TAP-A INPUT AND OUTPUT

163 


\section{LIST OF TABLES}

Table No.

1

2

3

4

5
Title

Drywe 11 Thermocouple Locations

Nondestructive Examination Data for Fuel Assemblies (Reference 5)

TAP-A Model Node Descriptiun

E-MAD Site Outdoor Air Temperatures Monthly Averages

Drywe11 Material Thermal Properties
68

Page No.

18

31

72

74 


\section{LIST OF FIGURES}

Figure No.

$\underline{\text { Title }}$

Page No.

1
2
3
4
5
6
7

Drywell Configuration

Surface Storage Cask Configuration

Soil Temperature Test Configuration

Fue 1 Temperature Test Configuration

Drywell Schematic

Drywell Section View

14

Drywe 11 Liner and Canister Showing

15

Instrumentation Conf iguration

Canister Configuration

Canister Closure Lid Configuration

21

Shield Plug Configuration

PWR Fuel Assembly Configuration

PWR Spent Fuel Assembly Predicted

Nominal Decay Heat Curve

E-MAD Storage Site Configuration

Drywell Storage Area Configuration

Drywe 11 Number 3 and Number 5 Storage Area

Instrumentation Well Configuration

Typical Drywell Thermocouple Elevations

Transfer Shield/Canister Installation

Configuration

Drywell Shield Adapter Configuration

(Shown Installed in Drywel1)

Drywell 3 Peak Canister, Liner, and Soil Temperature Distributions

Drywell 3 Peak Canister and Liner Axial Temperature Profiles 
Figure No.

25

26

27

28

29

30

31

32

33

34

35

36

37

38
Title

Page No.

55

Drywell 5 Peak Canister and Liner Axial

Temperature Profiles

Drywe 113 Canister Temperature Distributions

57

Drywell 3 Soil Temperature Distributions

58

Drywe 115 Canister Temperature Distributions

59

Drywel1 5 Soil Temperature Distributions 60

Near-Field Isolated Drywell Thermal Model : 66

Far-Field I solated Drywell Thermal Model 67

Laboratory Measured Grout Thermal Conductivity 75

E-MAD Soil Thermal Conductivity Derived From 76

Soil Temperature Test Data (Reference 2)

Near-Field Soil Thermal Conductivity Derived

77

From Drywe 115 Decay Heat Levels and

Temperature Data

Drywell 5 Test Data and Predictions

80

Comparison of Canister and Liner Axial

Temperature Profiles

Drywe 115 Test Data and Predictions

82

Compariṣn at About 85 Inches Below

Ground Leve ]

Drywe 115 Canister Test Data and Predictions

83

Comparison at 116 Inches Below Ground Level

Urywe 115 Test Data and Predictions

84

Comparison at About 145 Inclies Beluw Ground Leve 1

Drywell 5 Canister Test Data and Predictions

Comparison at 176 Inches Below Ground Level

Drywell 5 Test Data and Predictions

86

Comparison at About 205 Inches Below Ground Level 


\subsection{INTRODUCTION}

\subsection{PURPOSE OF REPORT}

The purpose of this report is to provide a test description, test results, and conclusions for the Isolated Drywell Test portion of the spent fuel Drywell Test performed at the E-MAD facility on the Nevada Test Site. This test was conducted as part of the Spent Fuel Handling and Packaging Program (SFHPP) 1978 Demonstration (further discussed in Section 1.3). The Drywell Test primary objective was to confirm, by actual testing, that commercial reactor spent fuel could be passively stored in a near-surface storage cell (drywell) at the Nevada Test Site.

The Isolated Drywe11 Test was begun on January 12, 1979, when a pressurized water reactor (PWR) spent fuel assembly was placed into a drywell storage cell near the E-MAD facility. The test hardware (shown in Figure 1) consisted of an instrumented carbon steel drywell liner, an instrumented stainless steel canister (containing the PWR spent fuel assembly) and a concrete-filled shield plug which supported the canister from the top of the liner. The drywell liner was grouted into a hole in the soil to assure intimate contact. A field of thermocouple wells was installed to measure ground temperature response to the spent fuel decay heat. Throughout the test period, temperature readings from thermocouples on the canister, liner, and in the soil were recorded.

A finite difference computer model (described in Section 6.0) was utilized to predict transient and steady-state canister, drywell, and soil temperatures. Results from the computer predictions and comparisons of the analytical predictions with the test data are presented in Section 7.0. 


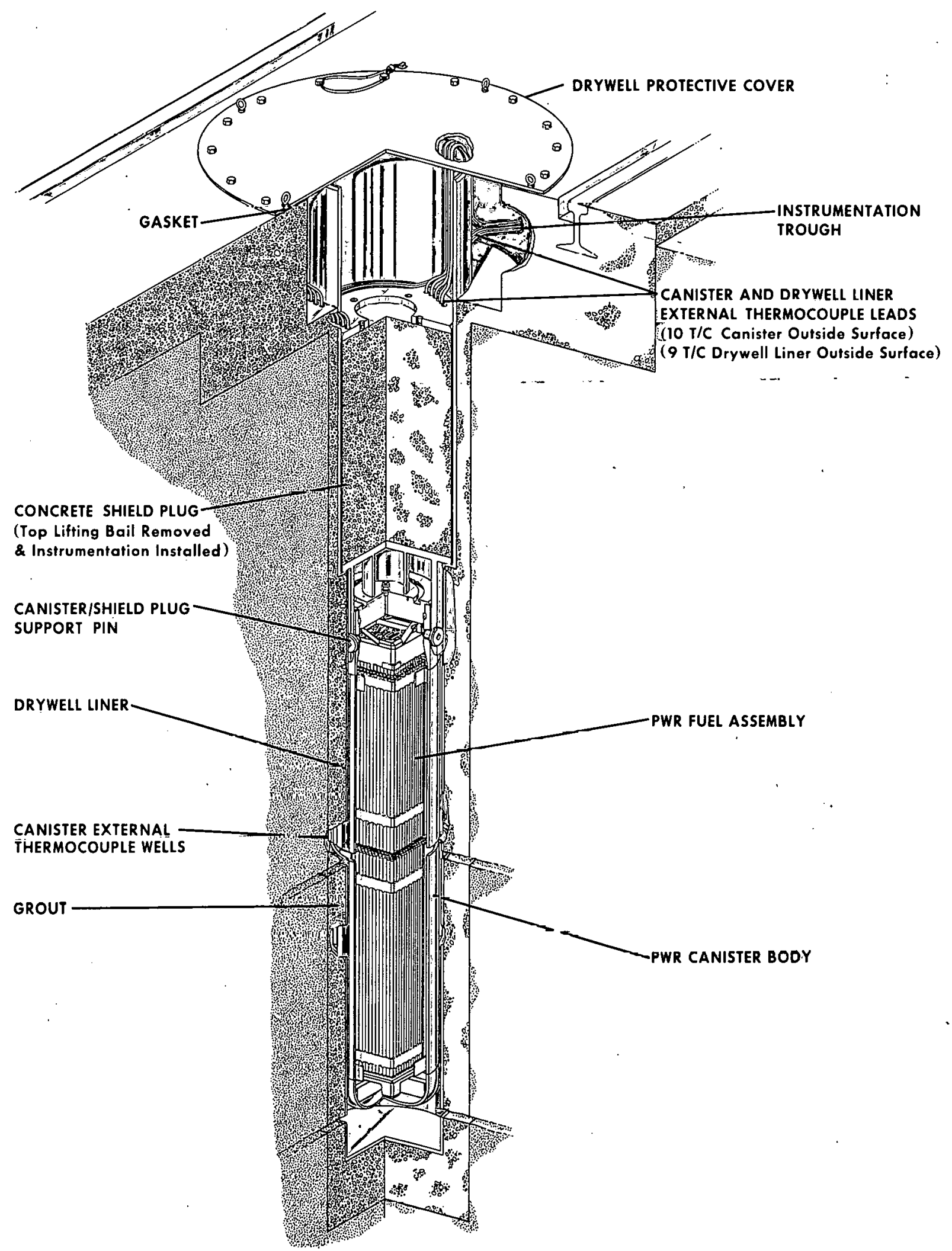

Figure 1. Drywell Configuration

614828-1FC 


\subsection{ORGANIZATION}

This report is organized to present the Isolated Drywell Test and its results in the following order:

- Introduction (including background of Spent Fuel Handling and Packaging Program).

- Conclusions drawn from the test results.

- Test objectives.

- Test hardware description.

- Test operation and results.

- Thermal model description.

- Comparison of test results with model predictions.

- Photographs of test hardware, assembly and installation.

- Test temperature data.

- Illustrations of test data.

- Computer code input and output data.

\subsection{BACKGROUND}

The Isolated Drywell Test described in this report was initiated as part of the Spent Fuel Hand7ing and Packaging Program (SFHPP) 1978 Demonstration Drywell Test in support of spent unreprocessed fuel storage at the Nevada Test Site. The objective of the SFHPP 1978 Demonstration was to develop and test the capability of satisfactorily encapsulating typical spent fuel assemblies from commercial nuclear power plants and to establish the suitability of one or more surface and near-surface concepts for the interim dry storage of the encapsulated fuel assemblies.

The E-MAD (Engine Maintenance, Assembly, and Disassembly) facility, constructed at the Nevada Test Site as part of the Nuclear Rocket Development Station, was chosen as the location for this demonstration because of its extensive existing 
capabilities for handling highly radioactive components and because of the desirable site characteristics for the proposed storage concepts. The E-MAD facility, operated for the Department of Energy by the Advanced Energy Systems Division (AESD) of the. Westinghouse Electric Corporation, is described in more detail in Reference 1.

Near-surface and above-surface storage concepts were chosen for testing during the SFHPP 1978 Demonstration. Each storage cell is designed to accommodate one canister, and the canister is designed to contain either one pressurized water reactor (PWR) fuel assembly or two boiling water reactor (BWR) fuel assemblies. The near-surface storage concept or drywell, shown in Figure 1, consists of a steel liner grouted into a shallow hole drilled in the alluvial soil at the E-MAD facility. A sealed canister containing the fuel assembly in a helium atmosphere is suspended from a shield plug which, in turn, is supported by a step in the liner. The above-ground storage concept, or Surface Storage Cask (SSC), is shown in Figure 2. Here, a steel liner identical to that used in the drywell is encased in a reinforced concrete silo, and the canister/ shield plug package is supported in the liner in the same manner as in the drywell. In both of these storage systems, the decay heat of the fuel assembly is passively transmitted to the storage cell and lhen dissipated to the environment. The drywe 11 and SSC storage cells themselves were constructed in an area immediately adjacent to the E-MAD facility.

An overriding requirement for the SFHPP 1978 Demonstration Prngram was that the spent fuel storage system and associated activities not result in an undue risk to the public, property, environment, or site employees. One means of assuring that this requirement would be met was to maintain the leak tight integrity of the fuel cladding and the canister. Because high temperature can affect the long-term integrity of both of these barriers to fission product release, thermal considerations were an important concern in the design of the storage cells. Preliminary analyses performed by the Hanford Engineering Development Laboratory (HEDL) established $715^{\circ} \mathrm{F}\left(380^{\circ} \mathrm{C}\right)$ as the fuel cladding temperature limit below which fuel cladding integrity would be maintained in a helium 

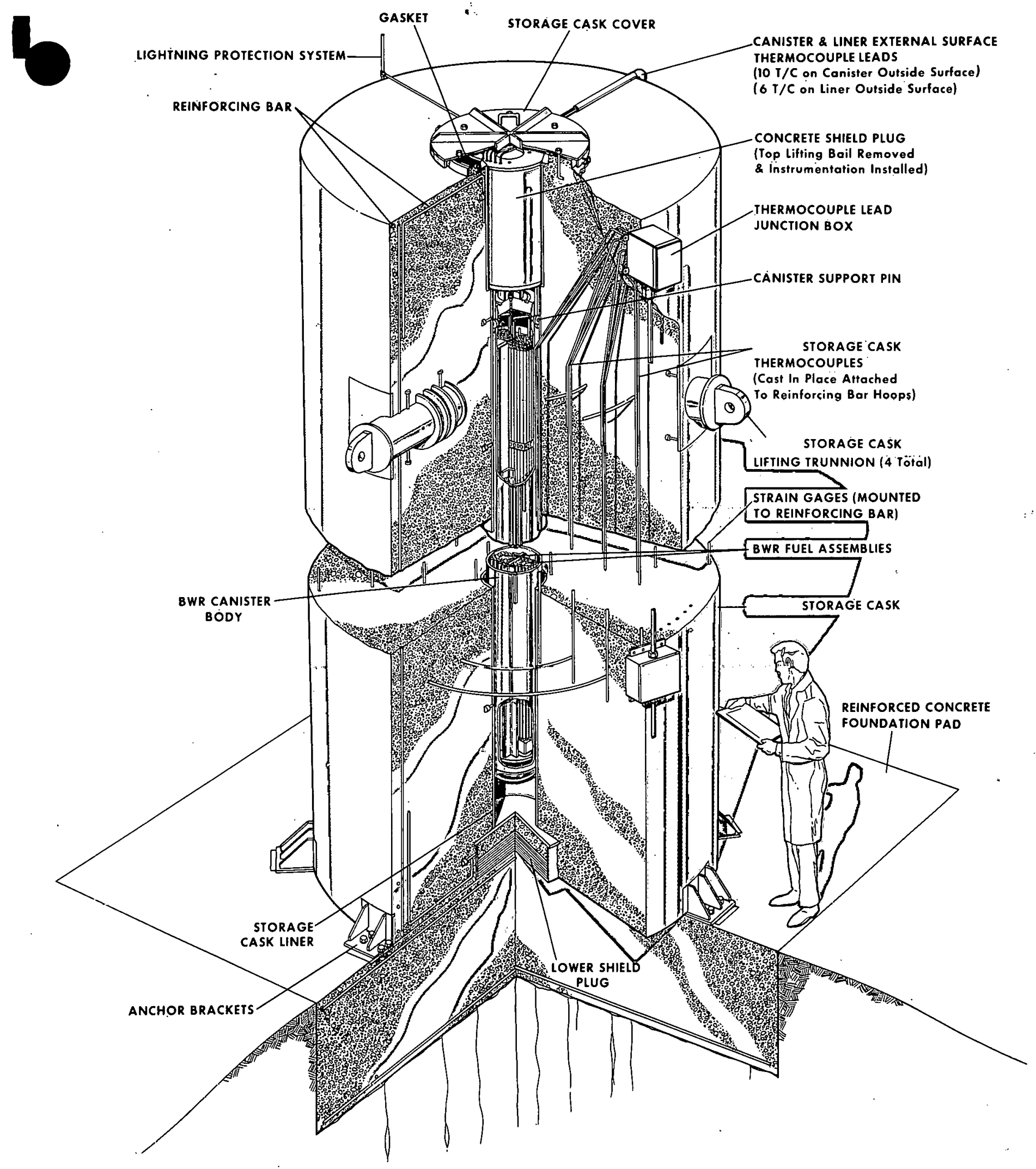

614927.1F日

Figure 2. Surface Storage Cask Configuration 
environment for long storage times (100 years). Scoping thermal analyses of the storage cell concepts indicated that cladding temperatures reached in the SSC would be well below the 1 imit, but that those reached in the drywell could approach the limit for the fuel assembly decay heat levels being considered. Therefore, a series of tests was initiated to experimentally verify. that fuel cladding temperatures would remain below the established limit and to obtain data for use in qualifying the thermal design model.

Two verification tests were defined which would provide temperature measurements, 1) from the canister out into the soil, and 2) inside a canister containing a spent fuel assembly. In the first test, the Soil Temperature Test (shown in Figure 3 ) was designed to utilize an in-ground electrically heated drywell configuration to measure the spatial temperature distributions on the canister surface, the drywell liner surface, and in the surrounding grout and soil. Canister temperatures from the Soil Temperature Test would then be input to a Fuel Temperature Test to determine peak fuel cladding temperatures. The Fuel Temperature Test apparatus (shown in Figure 4) was designed to utilize a. canister containing a spent fuel assembly and internal temperature instrumentation to measure fuel cladding thermal response to an imposed canister axial temperature profile measured during the Soil Temperature Test to approximate the thermal environment that would be present in an actual drywell. The canister is installed in a drywell liner which has electrical band heaters along the liner axial length. The Fuel Temperature Test apparatus is located in one of the large hot cells (West Process Cell) inside the E-MAD facility. It was decided to use a test within the E-MAD facility hot cells to determine canister interior temperatures rather than provide internal canister instrumentation wells in the actual storage canisters. It was judged that the addition of multiple thin-wall internal canister instrumentation tubes would greatly decrease the reliability of the canister to provide a leak tight radioactive containment boundary. The Soil Temperature Test coupled with the Fuel Temperature Test would provide canister and spent fuel clad temperature data for storage of the original SFHPP 1978 Demonstration spent fuel assemblies at E-MAD. 


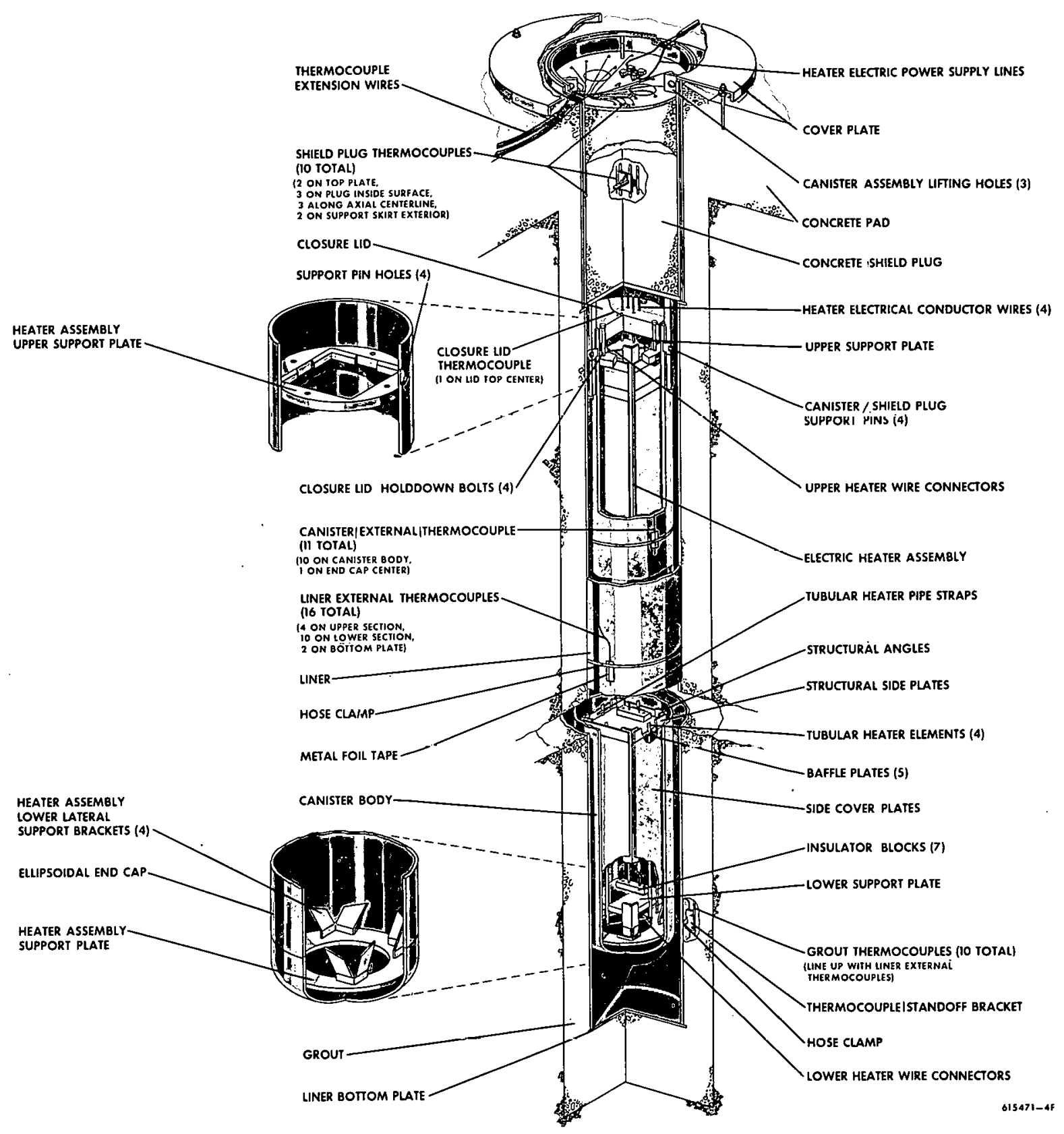

Figure 3. Soil Temperature Test Configuration 


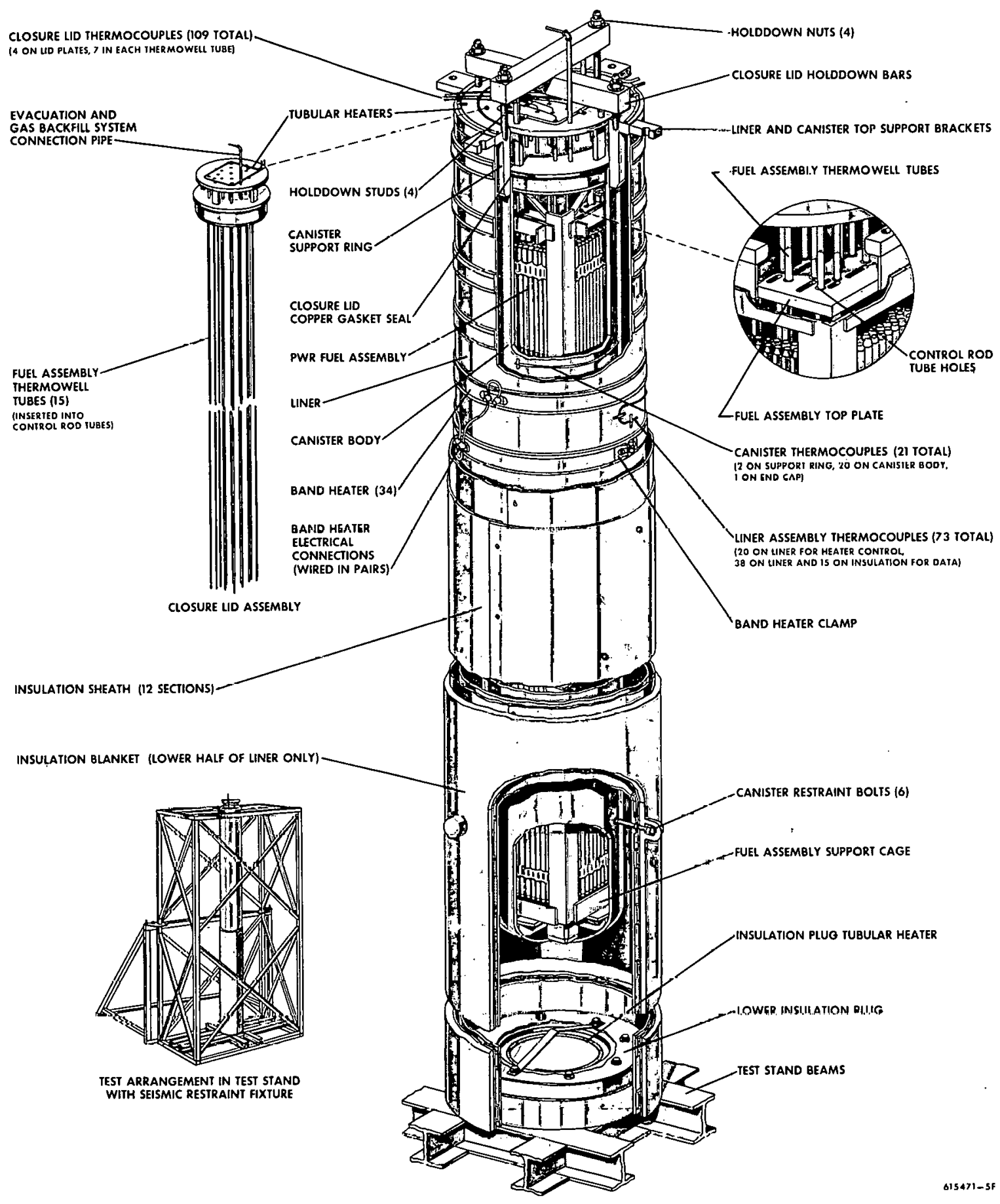

Figure 4. Fuel Temperature Test Configuration 
The storage cell experiments consisted of encapsulating spent fuel assemblies and placing them in storage with thermocouple instrumentation on the exterior of the fuel storage canister and throughout the storage cell. The fuel assemblies selected were characteristic of high burnup (25,000 MWD/MTU) fuel assemblies approximately three years out of the reactor with a thermal power level of approximately $1.25 \mathrm{~kW}$. The initial plan for the SFHPP 1978 Demonstration storage cell experiments was to place three canisters containing one PWR fuel assembly in drywells, to place one PWR canister in a Surface Storage Cask, and to place a canister containing two BWR fuel assemblies in the remaining drywell and Surface Storage Cask. In addition, it was planned to place the first PWR fuel assembly into the Fuel Temperature Test stand to determine fuel cladding temperatures using the measured canister temperatures from the Soil Temperature Test. Due to delays in procurement of BWR fuel assemblies, the plan was revised to place the first PWR fuel assembly into a Surface Storage Cask, to place the second and third PWR fuel assemblies into drywells, and to place the fourth PWR fuel assembly into the Fuel Temperature Test. Fuel encapsulations were performed at E-MAD during December 1978 and January 1979. An encapsulated PWR fuel assembly was placed in a Surface Storage Cask on December 12, 1978, and two other encapsulated PWR fuel assemblies were placed in drywells on January 12 and 24, 1979. The fourth PWR fuel assembly was placed in the Fuel Temperature Test on July 16, 1979.

Results from the Soil Temperature Test (Reference 2) provided sufficient data prior to the spent fuel storage cell testing schedular objective (late 1978) to confirm that fuel cladding temperatures for the spent fuel assemblies selected for testing would remain below established limits. Results from the Fuel Temperature Test (Reference 3) provided additional confirmation that fuel cladding temperatures are well below the limits. The Surface Storage Cask test is described and results are presented in Reference 4 . The results from the Isolated Drywell Test are presented and the Drywell Test hardware is described in this document. 


\subsection{CONCLUSIONS}

The following conclusions can be drawn from the results of the Isolated Drywell Test:

1. The peak measured canister temperature for an encapsulated PWR spent fuel assembly with an initial decay heat level of about 1.1 $\mathrm{KW}$ stored in a drywell configuration in soil typical of the Nevada Test Site was $254^{\circ} \mathrm{F}$. The peak measured liner temperature adjacent to the canister was $203^{\circ} \mathrm{F}$.

2. A 50 foot spacing between adjacent drywells in Nevada Test Site alluvial soil is judged to thermally isolate spent fuel assemblies with decay heat levels of about $1.0 \mathrm{~kW}$.

3. Peak drywell canister and liner temperatures occurred about 7 months after canister emplacement. The time to reach the peak temperatures was influenced by the seasonal ambient air temperatures, by the decrease in decay heat level, and by the amount of moisture in the soil.

4. Day-night variations in ambient air temperature have no effect on peak canister temperatures.

5. Combining the Isolated Drywell Test canister temperature data with results from the Fuel Temperature Test (Reference 3 ) shows that peak fuel cladding temperatures were about $360^{\circ} \mathrm{F}$, which is well below the established $715^{\circ} \mathrm{F}$ temperature limit. 


\subsection{TEST OBJECTIVES}

The objectives of the spent fuel Drywe 11. Test (as defined for the SFHPP 1978 Demonstration) were 1) to verify that spent fuel assemblies can be safely stored in Nevada Test Site soil, 2) to determine storage cell thermal properties and interface and boundary conditions to calibrate and verify thermal models, and 3) to determine thermal interactions of adjacent drywells.

The test objectives would be met by a combination of actual test results and calibrated computer model predictions. Encapsulated spent fuel assemblies would be installed into drywells and the thermal response of the canisters, drywell liners, and surrounding soil recorded. In addition, a computer model of the drywell would be prepared for comparison with the test results. The drywell model would be used to evaluate drywell performance beyond the limits of the test.

The maximum canister temperature level attained would be compared with the results of the Fuel Temperature Test measured temperatures and/or existing fuel. assembly/canister thermal models to evaluate drywell performance. Acceptable drywell storage capabilities would be verified if fuel cladding temperatures meet the $715^{\circ} \mathrm{F}$ criteria (see Section 1.3).

Transient test results would be compared to computer code predictions using the thermal power versus time predicted for the actual spent fuel assembly as input. Computer model thermal property and heat transfer correlation revisions would be made as necessary to update the model for good model/test agreement. Good agreement between computer model predictions and test data would qualify the computer model for use in evaluation of storage of various decay heat level fuel assemblies and for evaluation of drywell spacing variations. 
Due to delays in completion of the Fuel Temperature Test and delays in procurement of BWR spent fuel assemblies, the Drywell Test was limited to two drywells rather than the four originally planned. Two drywells were chosen for use such that the data provided would be for two thermally isolated drywells. The computer model to be utilized would be limited to a single thermally isolated drywell for comparison with results of the two isolated drywells. This first portion of the Drywell tests was, therefore, termed the Isolated Drywell Test.

As part of the Commercial Waste and Spent Fuel Package Program, several additional objectives were identified for the Drywell Test. To complete the originally planned testing, a Drywell Thermal Interaction Test was identified which would utilize three of the SFHPP 1978 Demonstration PWR spent fuel assemblies placed in adjacent drywells spaced 25 feet apart. The objective of this test was to provide additional data which could be used to evaluate arrays of drywells and which would be compared to computer code predictions for an array of drywells. In addition, it was decided to install a higher decay heat level (approximately $2 \mathrm{~kW}$ ) spent fuel assembly in the fourth drywell to evaluate isolated drywell response to higher power levels. This additional portion of the Drywell Test was termed the Nominal $2 \mathrm{~kW}$ Isolated Drywell Test.

This report provides the test data and computer model predictions from the Isolated Drywell Test. Test data and computer predictions from the planned Drywe 11 Thermal Interaction Test and Nominal $2 \mathrm{~kW}$ Isolated Drywell Test will be the subject of subsequent reports. 


\subsection{TEST HARDWARE DESCRIPTION}

\subsection{TEST ARRANGEMENT}

The Drywe 11 Test hardware arrangement is shown in Figures 1, 5 and 6 . The test hardware consists of 1) a drywe 11 liner grouted into a 26 inch diameter hole drilled approximately 23 feet deep, 2) a canister assembly consisting of a canister body, a closure lid and a concrete filled shield plug which supports the canister from the top section of the liner, 3) a PWR spent fuel assembly, 4) an array of soil instrumentation wells to measure ground temperature response and 5) a data acquisition system to record thermocouple data. Photographs of the Drywell Test hardware and its installation are shown in Appendix $A$.

\subsection{DRYWELL LINER}

The drywell liner is illustrated in Figure 7. The lower section of the liner consists of a 17 foot long section of 18 inch diameter by 0.375 inch wall pipe. The upper section of the liner is manufactured from a 51.5 inch long, 22 inch diameter, 0.75 inch wall pipe. The upper and lower sections of the liner are positioned concentrically to one another and welded to opposite sides of a 22 inch outside diameter, 17.25 inch inside diameter, 0.5 inch thick ring. This ring forms the ledge on which the 20 inch diameter shield plug (which is connected to the canister assembly) is supported. A 20 inch diameter, 0.5 inch thick plate is welded to the bottom of the lower portion of the liner to seal the lower end. Four 1.0 inch diameter holes spaced $90^{\circ}$ apart are located 1.5 inches below the top of the liner for handling and installation. The liner material is carbon steel. The assembly liner is shown in Figure $A-1$ in Appendix A.

\subsubsection{INSTRUMENTATION}

Nine tubes, 0.156 inch outside diameter and 0.086 inch inside diameter are attached to the outside of the liner and serve as thermocouple wells. The nine tubes extend from about 17 inches below the top of the 1 iner to about 2 inches 


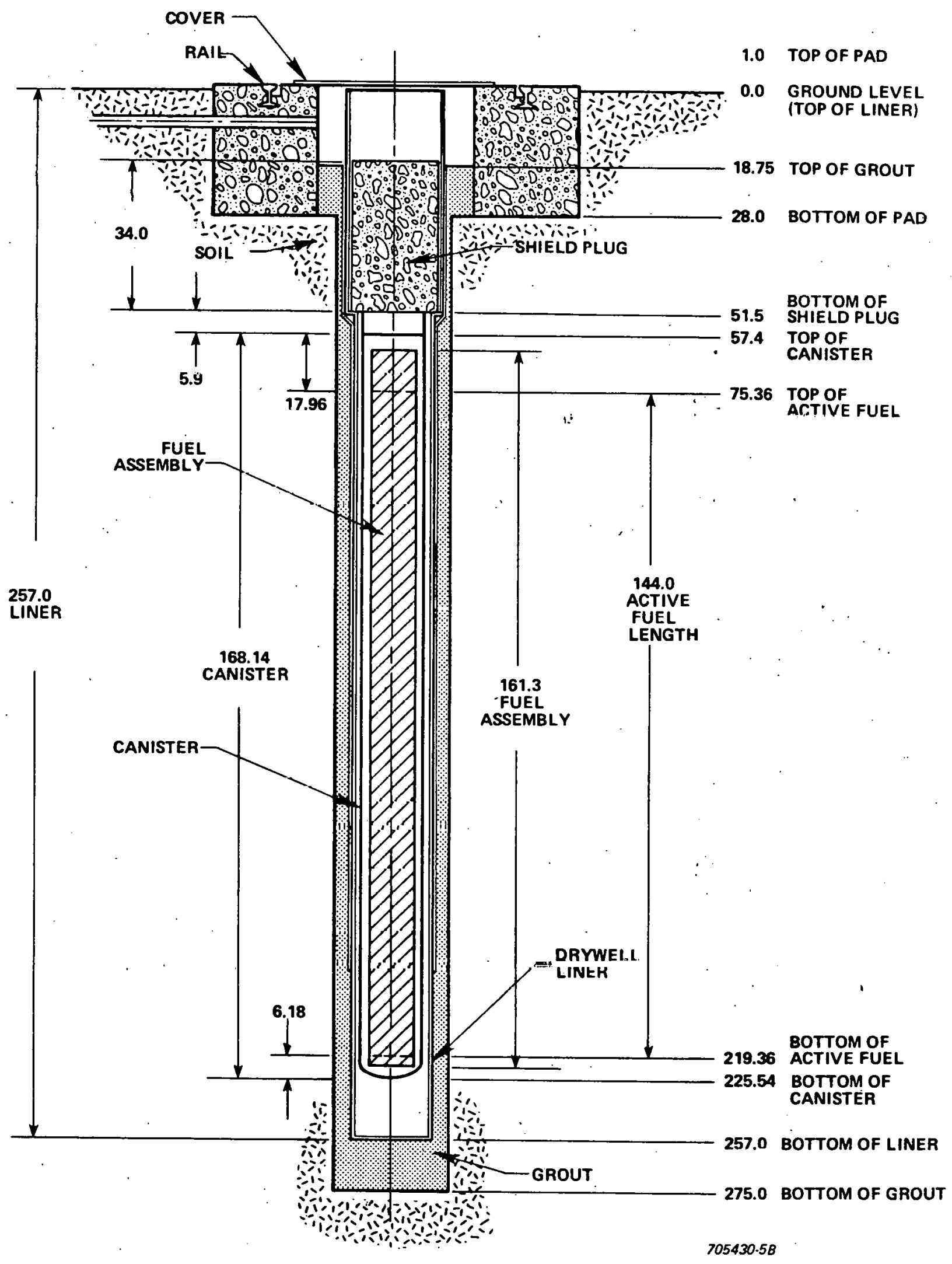

Figure 5. Drywe17 Schematic 


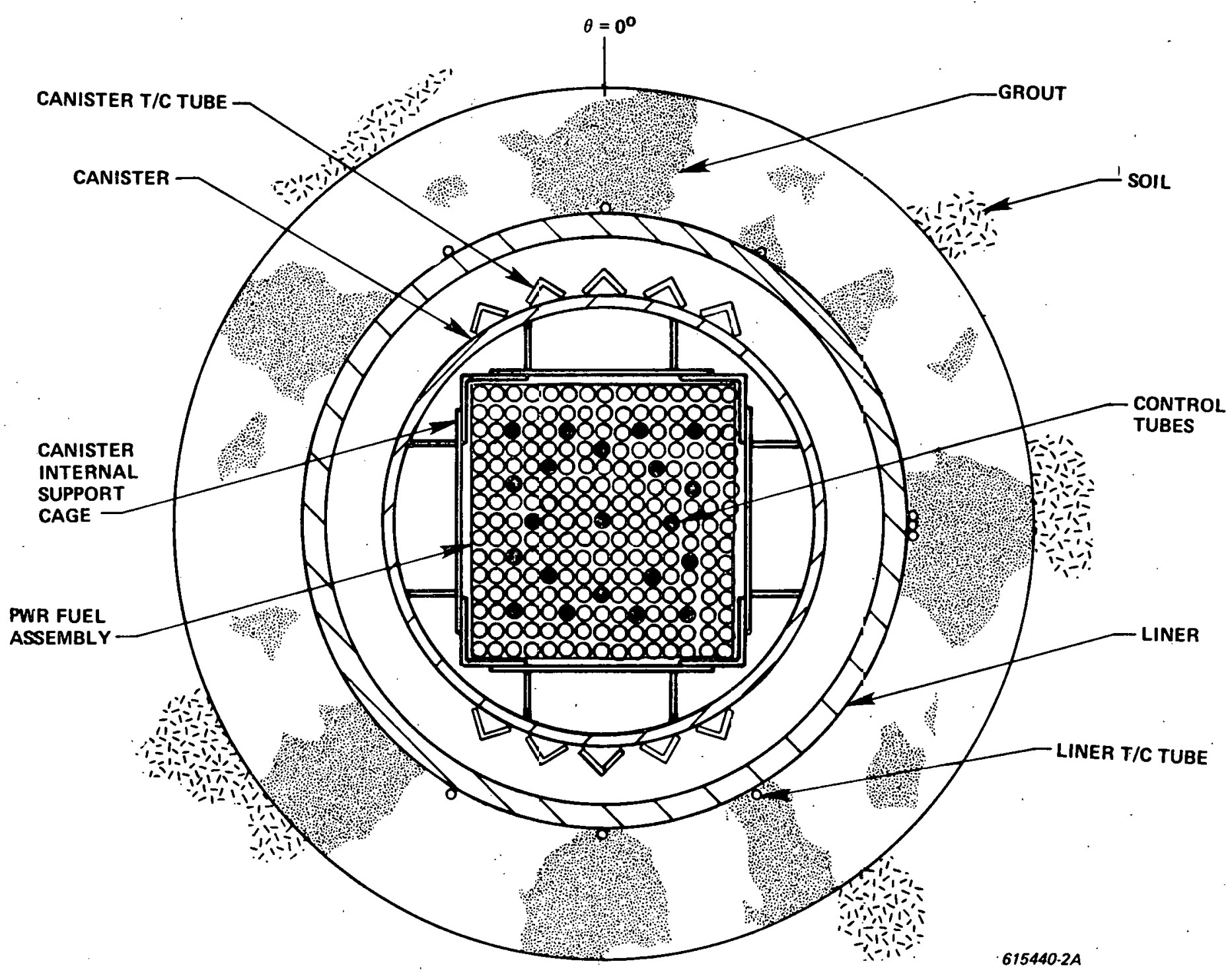

Figure 6. Drywell Section View 


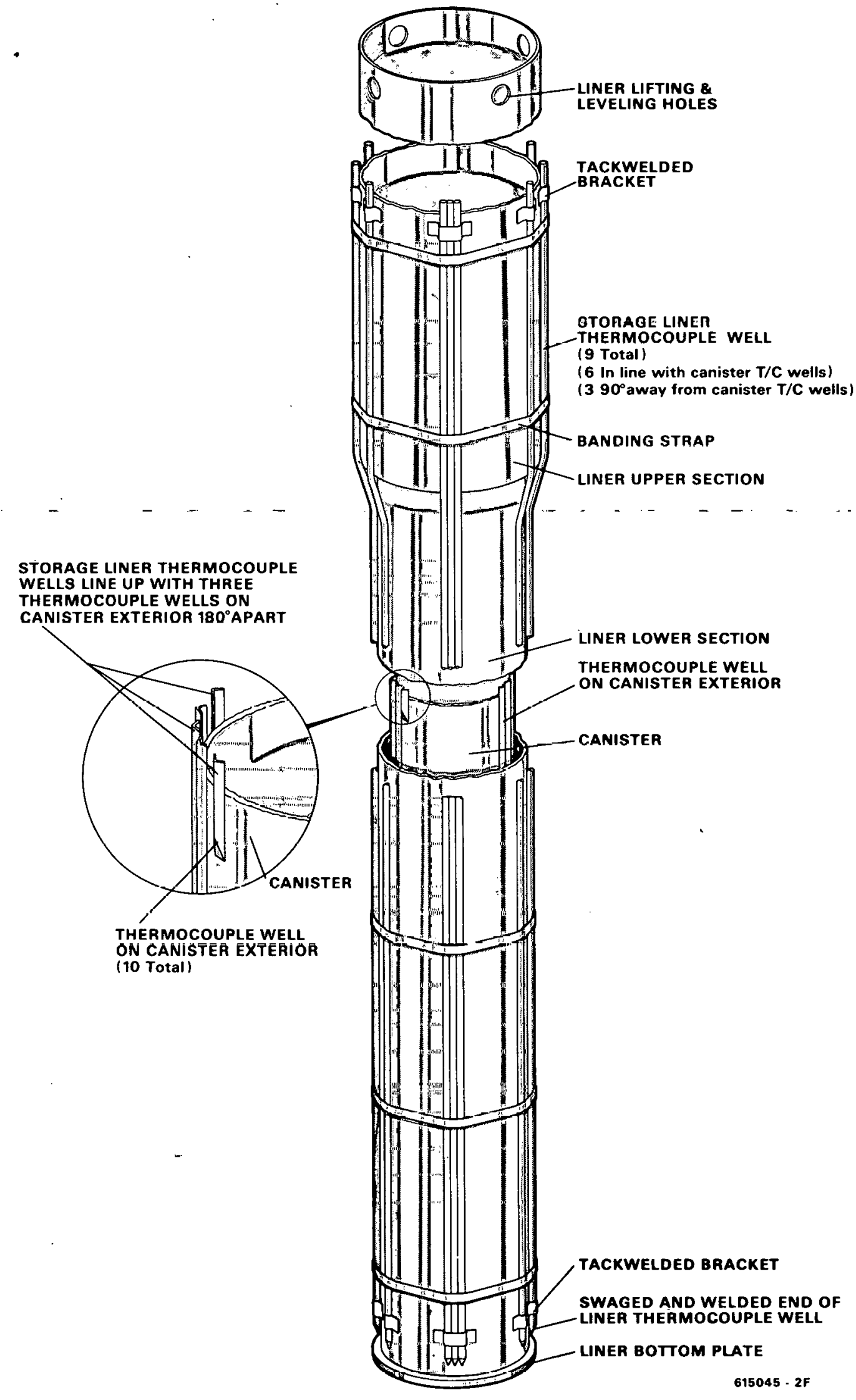

Figure 7. Drywell Liner and Canister Showing Instrumentation Configuration 
from the bottom of the liner. The tubes are clamped onto the liner by ten large hose clamps. The tubes are secured to liner near the top and bottom and at two intermediate points by 0.03 inch thick brackets spot welded to the liner as shown in Figure 7.

The thermocouple tubes are oriented around the liner in three groups as shown in Figures 6 and 7 . The first two groups each contain three tubes that are spaced $30^{\circ}$ apart. The middle tubes of these groups are $180^{\circ}$ apart. The third group has three tubes banded together. The middle tube of the third group is spaced $90^{n}$ fruil the middle tubes of the other groups. The six thermocouple tubes spaced $30^{\circ}$ apart match six of the ten thermocouple tubes on the canister when the canister is installed (see Figure 7). The third group of thermocouple tubes provides additional circumferential temperature reading positions. The tubes allow thermocouple installation to any elevation. The ends of the tubes are swaged and tack welded to prevent grout from filling the tubes during liner installation.

The installed elevation of the thermocouples in the tubes is controlled by the thermocouple length. The thermocouples are inserted until the transition boot between thermocouple and extension lead (see Section 4.7.1) contacts the top of the tube thus controlling the position of the thermocouple tip. The thermocouples are installed in each group of tubes so that there is one positioned at the middle of the PWR fuel assembly active fuel length, another one foot above the bottom of the active fuel and the other one foot below the top of the active fuel. These positions line up with positions on the canister. Table 1 provides depth and position data for the installed liner thermocouples.

\subsubsection{LINER INSTALLATION}

The liner assembly was positioned and leveled inside of a 26 inch diameter, 23 foot deep hole drilled into E-MAD soil. The liner is shown during installation in Figure. A-5. Prior to drilling the emplacement hole, an 84 inch wide by 28 inch deep concrete pad with standard gauge rails was poured (see Section 4.5). 
TABLE 1

DRYWELL THERMOCOUPLE LOCATIONS

Distance Below

\begin{tabular}{|c|c|c|c|}
\hline $\begin{array}{l}\text { Ground Level } \\
\text { (In.) }\end{array}$ & $\begin{array}{r}\text { Radius } \\
\text { (In.) }\end{array}$ & $\begin{array}{l}\text { Orientation } \\
\text { (Degrees) }\end{array}$ & Location \\
\hline & Drywe 1] & 0.5 & \\
\hline 203.5 & 120 & 150 & Instrumentation well $\mathrm{A}^{*}$ \\
\hline 203.5 & 60 & 90 & Instrumentation Well B \\
\hline 203.5 & 120 & 90 & Instrumentation Weil c \\
\hline 203.5 & 120 & 30 & Instrumentation Weli $D$ \\
\hline 205.75 & 9 & 30 & Liner \\
\hline 205.75 & 9 & 210 & Liner \\
\hline 205.75 & 9 & 90 & Liner \\
\hline 206.0 . & 7 & 30 & Canister \\
\hline 206.0 & 7 & 210 & Canister \\
\hline 176.0 & 7 & 15 & Canister \\
\hline 176.0 & 7 & 195 & Canister \\
\hline 143.5 & 120 & 150 & Instrumentation Well $\mathrm{A}$ \\
\hline 143.5 & 60 & 90 & Instrumentation Well B \\
\hline 143.5 & 120 & 90 & Instrumentation Well C \\
\hline 143.5 & 120 & 30 & Instrumentation Well D \\
\hline 145.75 & 9 & 0 & Liner \\
\hline $205.75 * \star$ & 9 & 180 & Liner \\
\hline 145.75 & 9 & 90 & Liner \\
\hline 14.6 .0 & 7 & 0 & Canister \\
\hline 116.0 & 7 & 180 & Canister \\
\hline 116.0 & 7 & 345 & Canister \\
\hline 116.0 & 7 & 165 & Canister \\
\hline 83.5 & 120 & 150 & Instrumentation well $\mathrm{A}$ \\
\hline 83.5 & 60 & 90 & Instrumentation well $B$ \\
\hline 83.5 & 120 & 90 & Instrumentation Well C \\
\hline 83.5 & 120 & 30 & Instrumentation Weil $D$ \\
\hline 85.75 & 9 & 330 & Liner \\
\hline 85.75 & 9 & 150 & Liner \\
\hline 85.75 & 9 & 90 & Liner \\
\hline 86 & 7 & 330 & Canister \\
\hline 86.0 & 7 & 150 & Canister \\
\hline
\end{tabular}

*See Figure 15 for Instrumentation Well Identification

**Broken thermocouple was replaced by longer length thermocouple.

Original thermocouple length was 145.75 inches. 
TABLE I (Cont'd)

\begin{tabular}{|c|c|c|c|c|}
\hline \multirow[t]{2}{*}{$\begin{array}{l}T / C \\
\text { No. }\end{array}$} & $\begin{array}{l}\text { Distance Below } \\
\text { Ground Level } \\
\text { (In.) }\end{array}$ & $\begin{array}{l}\text { Radius } \\
\text { (In.) }\end{array}$ & $\begin{array}{l}\text { Orientation } \\
\text { (Degrees) }\end{array}$ & \multirow[t]{2}{*}{ Location } \\
\hline & \multicolumn{3}{|c|}{ Drywell No. 3} & \\
\hline 824 & 203.5 & 120 & 150 & Instrumentation We $11 \mathrm{E} *$ \\
\hline 825 & 203.5 & 60 & 90 & Instrumentation Well $\mathrm{F}$ \\
\hline 826 & 203.5 & 120 & 90 & Instrumentation We $11 \mathrm{G}$ \\
\hline 827 & 203.5 & 120 & 30 & Ins trumentation Well $\mathrm{H}$ \\
\hline 828 & 205.75 & 9 & 30 & Liner \\
\hline 829 & 205.75 & 9 & 210 & Liner \\
\hline 830 & 205.75 & 9 & 90 & Liner \\
\hline 831 & 206.0 & 7 & 30 & Canister \\
\hline 832 & 206.0 & 7 & 210 & Canister \\
\hline 833 & 176.0 & 7 & 15 & Canister \\
\hline 834 & 176.0 & 7 & 195 & Canister \\
\hline 835 & 143.5 & 120 & 150 & Instrumentation well $\mathrm{E}$ \\
\hline 836 & 143.5 & 60 & 90 & Instrumentation Well $\bar{F}$ \\
\hline 83 & 143.5 & 120 & 90 & Instrumentation Well G \\
\hline 838 & 143.5 & 120 & 30 & Instrumentation Well $\mathrm{H}$ \\
\hline 839 & 145.75 & 9 & 0 & Liner \\
\hline 840 & 145.75 & 9 & 180 & Liner \\
\hline 841 & 145.75 & y & $90^{\circ}$ & Liner \\
\hline 842 & 146.0 & 7 & 0 & Canister \\
\hline 843 & 146.0 & 7 & 180 & Canister \\
\hline 84 & 116.0 & 7 & 345 & Canister \\
\hline 84 & 116.0 & 7 & 165 & Canister \\
\hline 846 & 83.5 & 120 & 150 & Instrumentation Well $\mathrm{E}$ \\
\hline 847 & 83.5 & 60 & 90 & Instrumentation Well F \\
\hline $84 \varepsilon$ & 83.5 & 120 & 90 & Instrumentation Well G \\
\hline 84 & 83.5 & 120 & 30 & Instrumentation Well $\mathrm{H}$ \\
\hline 85 & 85.75 & 9 & 330 & Liner \\
\hline 85 & 85.75 & 9 & 150 & Liner \\
\hline 852 & 85.75 & 9 & 90 & Liner \\
\hline $\begin{array}{l}853 \\
854\end{array}$ & $\begin{array}{l}86.0 \\
86.0\end{array}$ & $\begin{array}{l}7 \\
7\end{array}$ & $\begin{array}{l}330 \\
150\end{array}$ & Canister \\
\hline & & & & \\
\hline
\end{tabular}

*See Figure 15 for Instrumentation Well Identification 
The pad has an 18.75 inch deep by 37.25 inch diameter annulus around the upper section of the liner in which a portable lead shield adapter is installed prior to emplacement of the canister (see Section 4.8.2).

The pad provided a reference datum to aid in drilling and liner installation operations. After the positioning of the liner into the emplacement hole, grout was pumped into the bottom of the emplacement hole until it reached a level about 1 to 2 feet above the bottom of the liner. The aggregate used in the grout consisted of 2 parts soil removed from the emplacement hnle to 1 . part luminite. This grout was allowed to set to secure the liner in its properly aligned position and to reduce the bouyancy effect of the grout on the liner assembly. After this grout set, the annulus between the liner and the emplacement hole was filled with grout to the top of the instrumentation tubes. After the grout was installed, 0.072 inch diameter wires, installed prior to 1 iner shipment to protect the tubes and to keep them clean, were removed from the nine instrumentation wells.

\subsection{CANISTER ASSEMBLY}

The canister assembly consists of a canister body, a closure lid and a shield plug. The canister assembly in a drywell is illustrated in Figula 1. The canister described below was designed to accommodate. one PWR spent fuel assembly.

\subsubsection{CANISTER BODY}

The canister body is illustrated in Figure 8 . The main body of a PWR canister is a standard 14 inch outside diameter, 0.375 inch wall, 304 stainless steel pipe 154 inches long. Welded to the bottom of this pipe is a standard 14 inch diameter, 6.5 inch high ellipsoidal end cap. This end cap has welded into it a cruciform formed of a 0.75 inch thick 304 stainless steel plate with four 0.25 inch thick 304 stainless steel vertical gussets welded to the underside. This cruciform supports the bottom of a PWR fuel assembly.

The top of the PWR canister body consists of a section of 14 inch outside diameter, 0.937 inch wall, 304 stainless steel pipe approximately 9 inches 


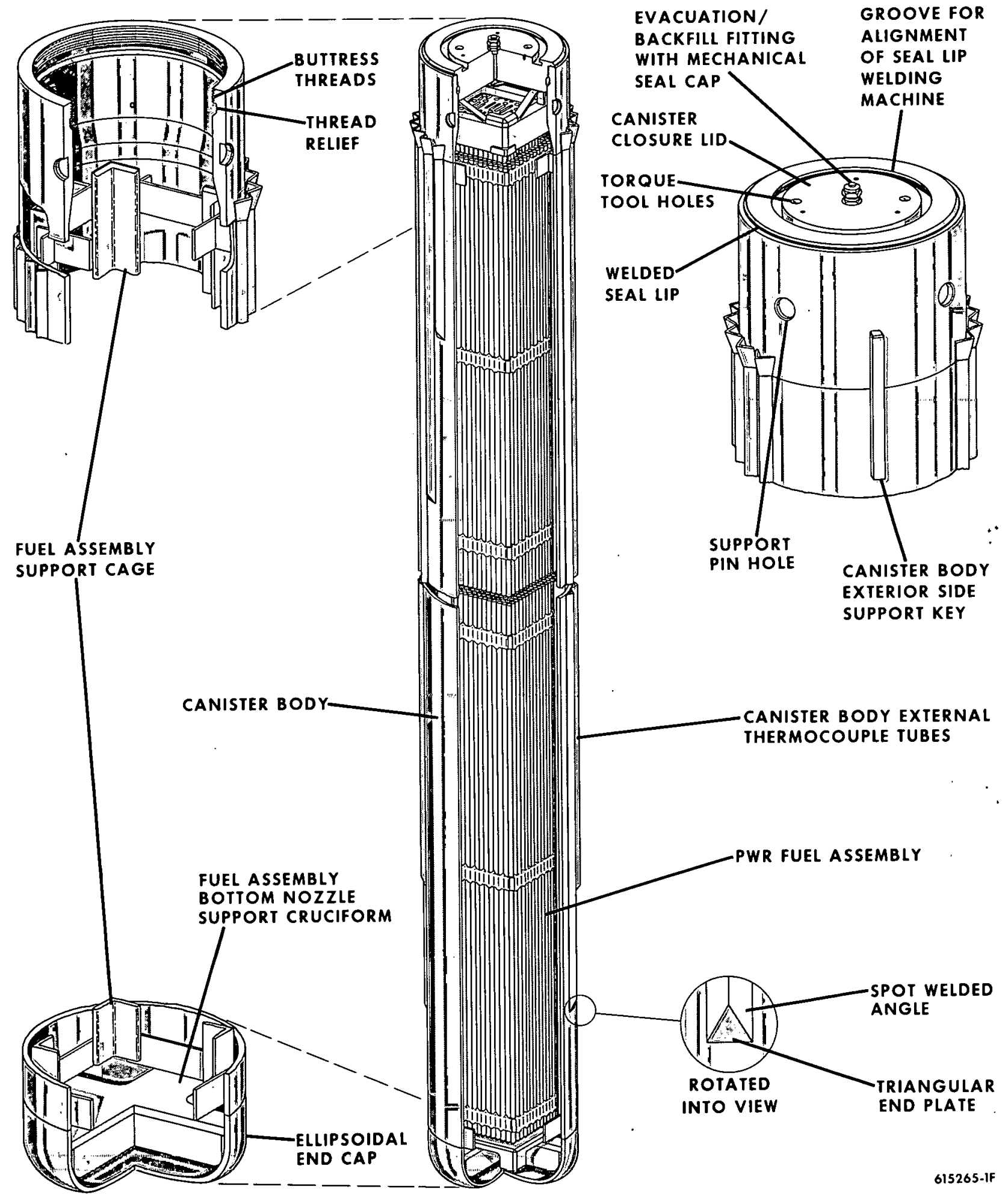

Figure 8. Canister Configuration 
long. This section is welded to the 0.375 inch thick main body pipe and contains machined threads which mate with the closure lid. The outside upper surface of the canister body contains 4 blind holes equally spaced around the pipe circumference for the attachment of the shield plug. Two 0.75 inch square bars (keys) are welded to the outside of the canister body to support the canister during remote operations and to align the shield plug so that the instrumentation tubes on both components are properly aligned.

Welded to the inside of the PWR canister body is a fuel assembly support cage formed of standard 2 inch by 2 inch by 0.18 inch thick 304 stainless steel. angles tied together on four sides at six elevations by 7.12 inch long by 2 inches high by 0.18 inch thick plates. At the top of the cage, eight additional straps are welded bctwcen the canister body pipe and the toj caye slraps to provide cage centering and support.

\subsubsection{INSTRUMENTATION}

The canister has ten thermocouple "tubes" for insertion of thermocouples after emplacement in a drywell. The thermocouple "tubes" consist of 0.75 inch by 0.75 inch angles, spot-welded to the outside of the canister body. A funnel is formed at. the top of each tube by a 1.25 inch by 1.25 inch angle, cut to match the smaller angle and welded to the top of the tube (see Figure 8). The funnel is provided to allow for potential radial and azimuthal mismatch between shield plug and canister body instrumentation tubes and thereby assure proper thermocouple installation. A triangular plate is welded to the bottom of each tube. Contact with the angled plate at the bottom of each tube is intended to cause the tip of the thermocouple to be diverted toward and eventually touch the canister body.

Five thermocouple tubes are located on opposite sides of the canister. The five tubes in each group are spaced $15^{\circ}$ apart and extend down the canister to lengths matching the PWR fuel assembly active fuel middle, 2.5 feet above and below the active fuel middle and 1.0 foot from each end of the active fuel. Each different tube length is matched by a tube of the same length $180^{\circ}$ away. 
The thermocouples are installed through tubes in the shield plug until they contact the bottom of each instrumentation tube. When installed, the thermocouples measure temperatures at five different elevations on both sides of the canister to determine the axial canister temperature profile. The uppermost, middle and lowermost thermocouples are located at the same elevations as those in the drywell liner. Table 1 identifies the thermocouples installed in the canisters for the Isolated Drywell Test.

\subsubsection{CANISTER CLOSURE LID}

The carlister closure lid is illustrated in Figure 9. The closure lid is a flat disc, 3.5 inches thick and 12.5 inches in diameter. This disc has approximately 1.0 inch of buttress threads machined near the top which mate with threads machined into the thicker section of 14 inch diameter pipe at the top of the canister body. The top outside surface of the closure lid is machined to form a seal lip for remote seal welding of the canister after the fuel assembly is installed. Features on the top surface of the closure lid include a machined groove for alignment of the seal welding machine with the machined seal lip, provisions for the lifting and torquing tool, and a fitting with a mechanically sealed cap through which helium is introduced into the canister. The bottom 1.0 inch of the closure lid serves as a lead-in for the installation of the lid into the canister body.

The seal lip on the canister closure lid is welded to the canister body to complete the containment boundary. The gas fitting on the top of the closure lid is used to evacuate the canister and backfill with helium. The helium serves to provide an indicator for initial leak checking of the closure lid seal weld and the gas fitting mechanical seal, to stabilize the fuel assembly in an inert atmosphere, and to enhance conductive heat transfer to the canister.

\subsubsection{SHIELD PLUG}

The canister is attached to a shield plug before emplacement into storage. The shield plug shown in Figure 10 is a 20 inch outside diameter, 0.25 inch wall 


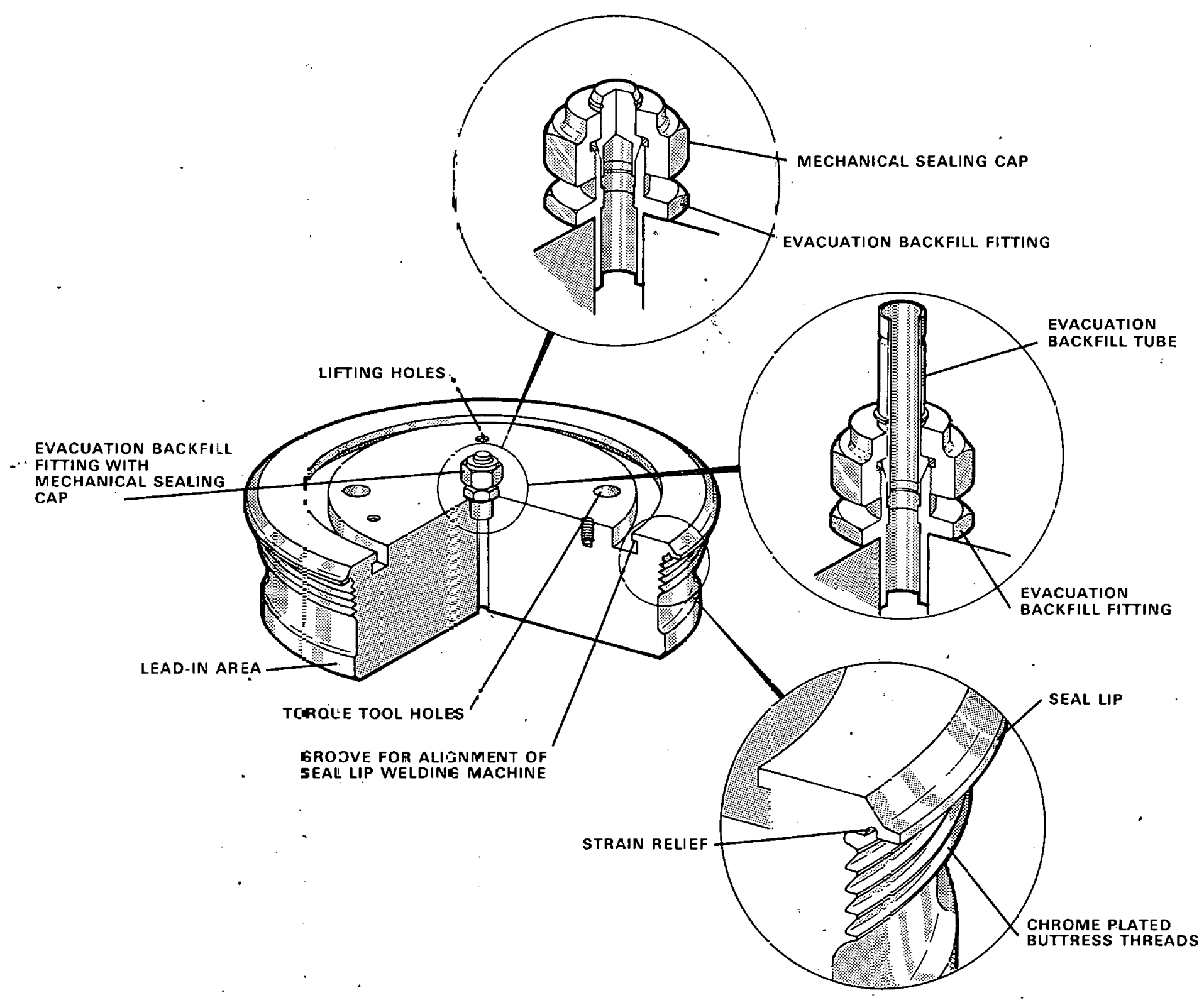

Figure 9. Canister Closure Lid Configuration 


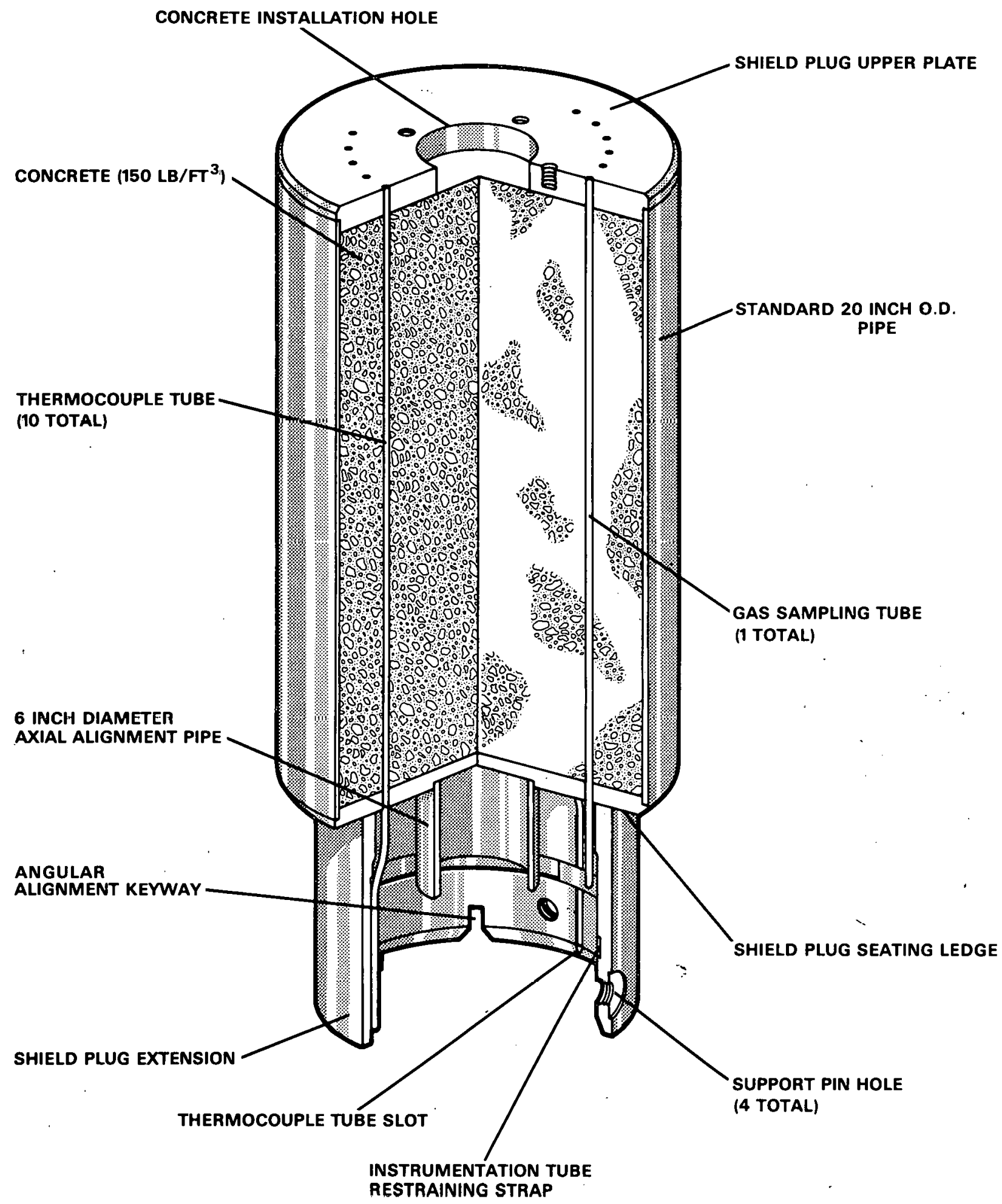

615045-1C

Figure 10. Shield Plug Configuration 
carbon steel pipe approximately 34 inches long with a 1.5 inch thick plate welded to the top and a 1.0 inch thick plate welded to the bottom. The volume between the two end plates is filled with concrete for shielding. Extending from the bottom plate of the assembly is a 16 inch outside diameter, 1.031 inch wall, carbon steel pipe approximately 13.5 inches long. This pipe extension contains four tapped holes $90^{\circ}$ apart which accept the canister support pins. It is through these pins that the canister is secured to the shield plug. The shield plug is lowered over the canister (which fits inside of the 16 inch dlameter extension) and the support pins are threaded into the shield plug extension. The pins protrude from the inside of the extension into four flatbottomed holes in the upper portion of the canister.

The shicld plug has eleven 0.086 inch inside diameter tubes which extend from the upper plate, through the lower plate down to the bottom of the shield plug extension, ten for routing thermocouples to the canister and one for sampling the atmosphere above the closure lid. The tubes are routed through slots in the bottom portion of the extension so as not to interfere with the canister body. The tubes are secured to the extension by spot welded straps. The shield plug has two sets of five tubes with $15^{\circ}$ spacing between tubes. The tubes are oriented with respect to the thermocouple tubes on the canister by an alignment keyway in the shield plug extension and a bar (key) on the outside of the canister.

\subsubsection{CANISTER ASSEMBLY INSTALLATION}

The encapsulated fueled canister assemblies are installed into the drywell using a railcar mounted transfer shield and a drywell shield adapter which are described in Section 4.8. The Engine Installation Vehicle, Manned Control Car and L-3 locomotive previously used as part of the Nuclear Rocket Development Station are used to transport the canister to the drywel1. The drywells are centered between rails and the concrete shield pad above each drywell is level to facilitate transfer shield and drywell alignment for transfer of the canister into the drywell. Horizontal alignment of the transfer shield with the 
drywe 11 is accomplished by aligning a pointer on the transfer shield foot valve housing with targets inscribed on the top of the drywell concrete pad. The operations of the transfer shield are described in detail in Reference 1.

\subsection{PWR SPENT FUEL ASSEMBLY}

Five specific PWR spent fuel assemblies were selected for the SFHPP 1978 Demonstration from the Florida Power and Light Turkey Point reactor. A representative Turkey Point fuel assembly is shown schematically in Figure 11 . The selected assemblies are 161.3 inches long (prior to irradiation) with a square cross section having a maximum distance across flats of 8.43 inches (including grids). The overall length is made up of a top nozzle, the fuel rods, and the bottom nozzle. The fuel rods consist of a 15 by 15 array of 0.422 inch diameter Zircaloy cladding around $\mathrm{UO}_{2}$ pellets. The fuel rods are arranged on a square pitch of 0.563 inches. The active fuel length is 144 inches. The fuel rods are laterally constrained by a series of seven grids located along the length of the rods. The PWR fuel assemblies are supported by the bottom nozzle when in the vertical position. The bottom nozzle has four square feet located at the corners of the assembly. These feet interface with the cruciform in the bottom of the canister. A PWR fuel assembly weighs approximately 1450 pounds.

The specific PWR fuel assemblies were chosen based on their approximately 25,000 MWD/MTU burnup and their 3 year decay time (time out of reactor). Initial predictions of cladding temperatures in drywell's and SSC's indicated that maximum decay heat levels for spent fuel should be limited to less than 1.25 kW. The five Turkey Point fuel assemblies (Serial Numbers B02, B03, B17, B41, and B43) were chosen based on an estimated decay heat level slightly less than $1.25 \mathrm{~kW}$ at the earliest dry storage emplacement date at E-MAD (November 1978). This decay heat level was based on the nominal predicted decay heat curve (Figure 12) and the October 1975 discharge date for the assemblies. Specific data (operating statistics, dimensional measurements, weight data, flux and gamma scan data, etc.) concerning the spent fuel assemblies was collected during nondestructive examination prior to their shipment to E-MAD and is reported 


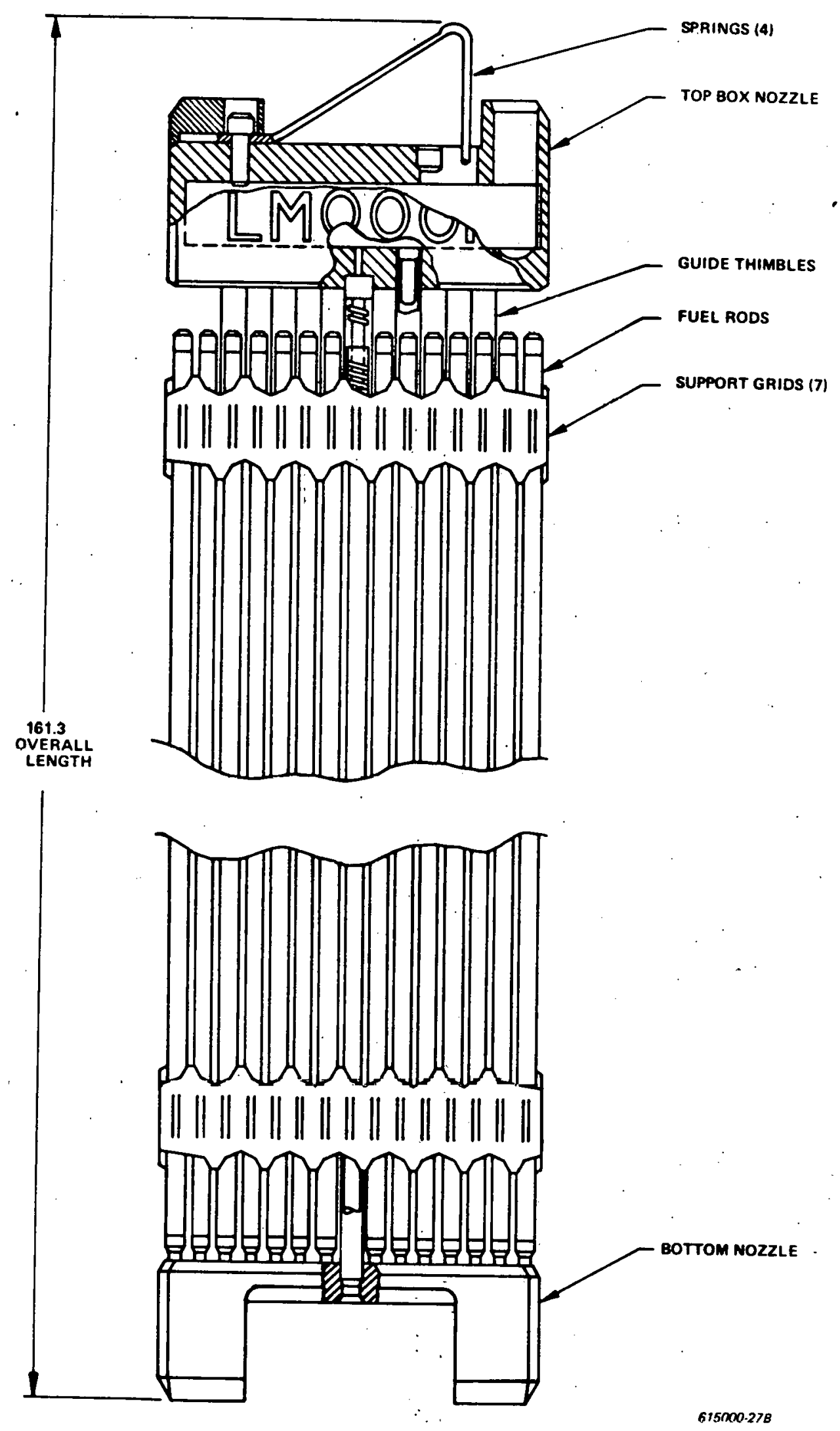

Figure 11. PWR Fuel Assembly Configuration 


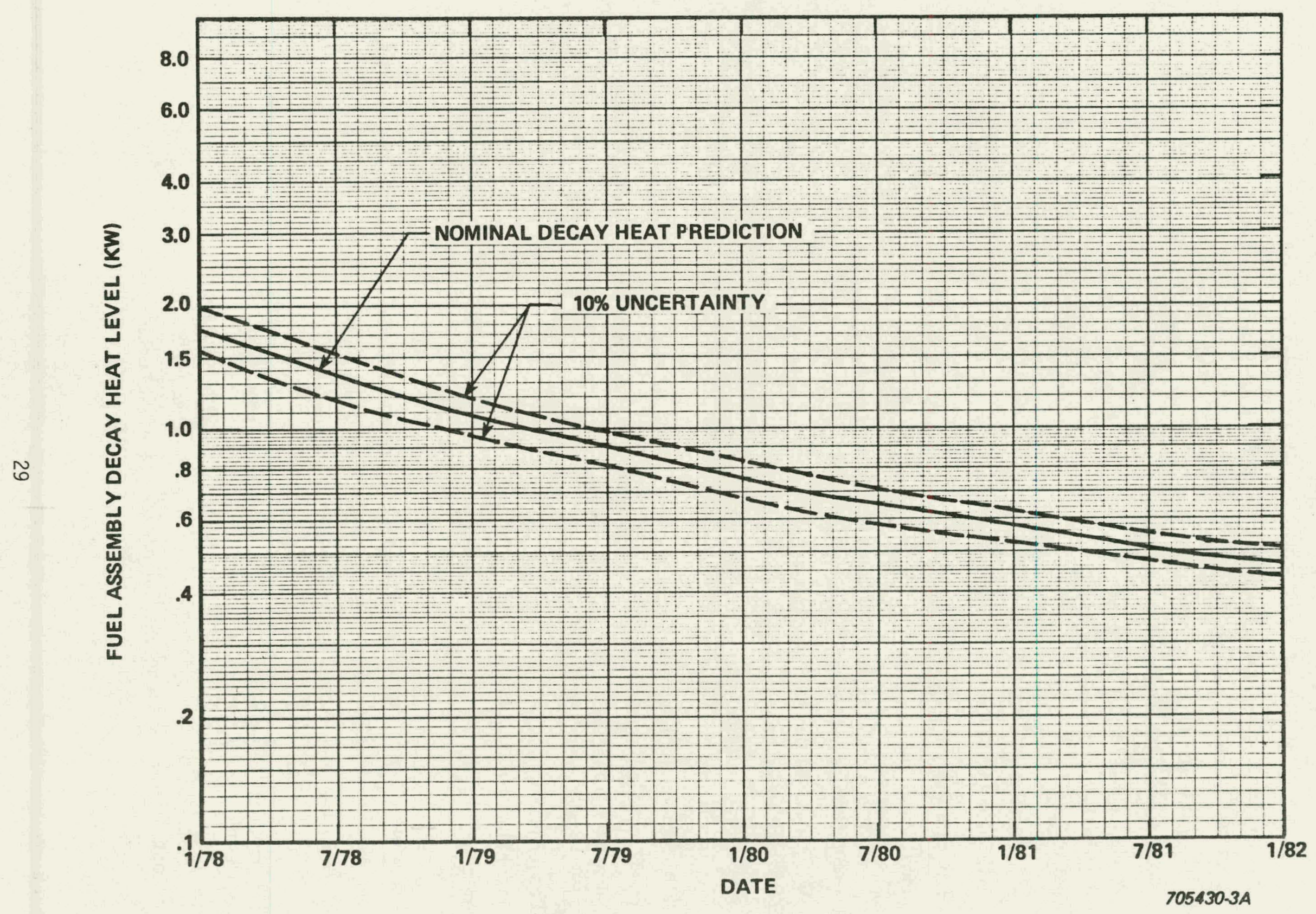

Figure 12. PWR Spent Fuel Assembly Predicted Nominal Decay Heat Curve 
in Reference 5. Fuel assemblies Serial Numbers B03 and B41 were selected for testing in the drywells. Specific physical data from Reference 5 pertinent to this test are provided in Table 2. This data shows that the overali fuel assembly length increased to slightly more than 161.55 inches and that the active fuel length increased to about 144.5 inches from the irradiation. Figure A-8 shows one of these two fuel assemblies being lowered into a canister.

\subsection{STORAGE SITE}

The storage site for the Drywell Test as well as the Surface Storage Casks is located on the west side of the E-MAD building within the security fenced area surrounding the E-MAD complex as shown in Figure 13. Early in the SFHPP 1978 Demonstration, it was decided that canister emplacement into the drywells would utilize existing rail equipment at E-MAD. The area west of the E-MAD building was chosen as the storage site since it is fairly level and would allow rail spur installation with a minimum of site modifications.

The main railroad track extends directly north from the E-MAD Hot Bay to the E-MAD complex security fence and beyond. A switch located 100 feel south of the north fence was used to start a new rail spur for the drywcll storage site. The spur consists of one track which parallels the main track and descends a 2.5 percent grade to the storage site. An additional switch was installed to permit later construction of additional spurs for future expansion of the site.

The drywells are centered between rail tracks embedded in a reinforced concrete pad as illustrated in Figure 14. The pad is 84 inches wide by 28 inches deep by 235 feet long. The pad provides 1) a level surface to facilitate emplacement of the canister with the transfer shield, 2) support for the rail equipment during emplacement and 3) shielding in the immediate area around the drywe11. The pad was constructed in stages. First, the periphery forms, the reinforcing rod, and five 37.25 inch outside diameter drywell forms spaced at 25 foot intervals along the length of the drywell storage area were installed. 
TABLE 2

NONDESTRUCTIVE EXAMINATION DATA

FOR FUEL ASSEMBLIES (REFERENCE 5)

Average Burnup - 25,595 MWD/MTU

Discharge Date - October 25, 1975

Measured Weight

$\underline{B 03}$
1450 Pounds
1452 Pounds

Measured Irradiated Length (from bottom of top plate to top of bottom nozzle plate; nominally 153.12 -inches) -

B03 $\quad$ B41
A-B. Corner
153.356 Inches
153.368 Inches
$A-D$ Corner
153.365 Inches
153.382 Inches

Measured Irradiated Across Flats Dimensions (pin to pin, nominally 8.302

$\underline{B 03} \quad \underline{B} 4$

Height Above Across Flats Across Flats Across Flats Across Flats Bottom Nozzle(In.) $0^{\circ}$ to $180^{\circ}$ (In.) $90^{\circ}$ to $270^{\circ}$ (In.) $0^{\circ}$ to $180^{\circ}$ (In.) $90^{\circ}$ to $270^{\circ}$ (In.)

$\begin{array}{rrrrr}15 & 8.279 & 8.301 & 8.312 & 8.307 \\ 46 & 8.308 & 8.317 & 8.296 & 8.308 \\ 72 & 8.283 & 8.298 & 8.299 & 8.322 \\ 99 & 8.313 & 8.291 & 8.277 & 8.317 \\ 125 & 8.298 & 8.305 & 8.292 & 8.301 \\ 146 & 8.285 & 8.308 & 8.289 & 8.302\end{array}$

Measured Irradiated Rod Dimensions

$\underline{\mathrm{B} 03}$

$\underline{B 41}$

\begin{tabular}{|c|c|c|c|c|}
\hline Fuel Pin & $\begin{array}{l}\text { Overall } \\
\text { Length (In.) }\end{array}$ & $\begin{array}{l}\text { Fuel Stack } \\
\text { Length (In.) }\end{array}$ & $\begin{array}{c}\text { Overall } \\
\text { Length (In.) }\end{array}$ & $\begin{array}{l}\text { Fuel Stack } \\
\text { Length (In.) }\end{array}$ \\
\hline $\begin{array}{l}\text { G7 } \\
\text { G9 } \\
\text { J8 } \\
\text { I9 } \\
\text { H6 }\end{array}$ & $\begin{array}{l}152.455 \\
152.386 \\
152.266 \\
152.414 \\
152.430\end{array}$ & $\begin{array}{l}144.50 \\
144.50 \\
144.56 \\
144.44 \\
144.56\end{array}$ & $\begin{array}{r}152.426 \\
152.644 \\
152.616 \\
152.513 \\
152.452\end{array}$ & $\begin{array}{l}144.31 \\
144.81 \\
144.31 \\
144.50 \\
144.81\end{array}$ \\
\hline
\end{tabular}




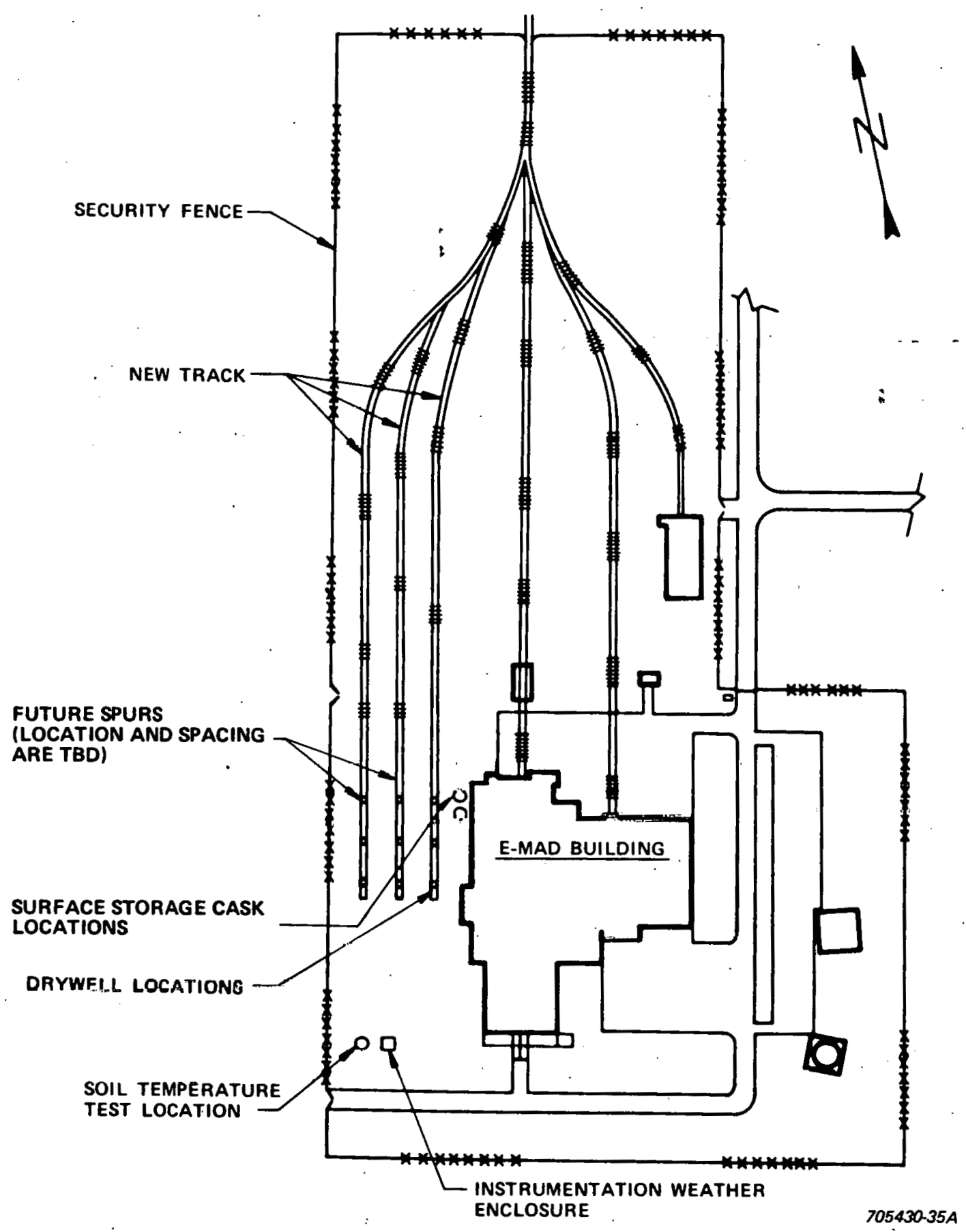

Figure 13. E-MAD Storage Site Configuration 


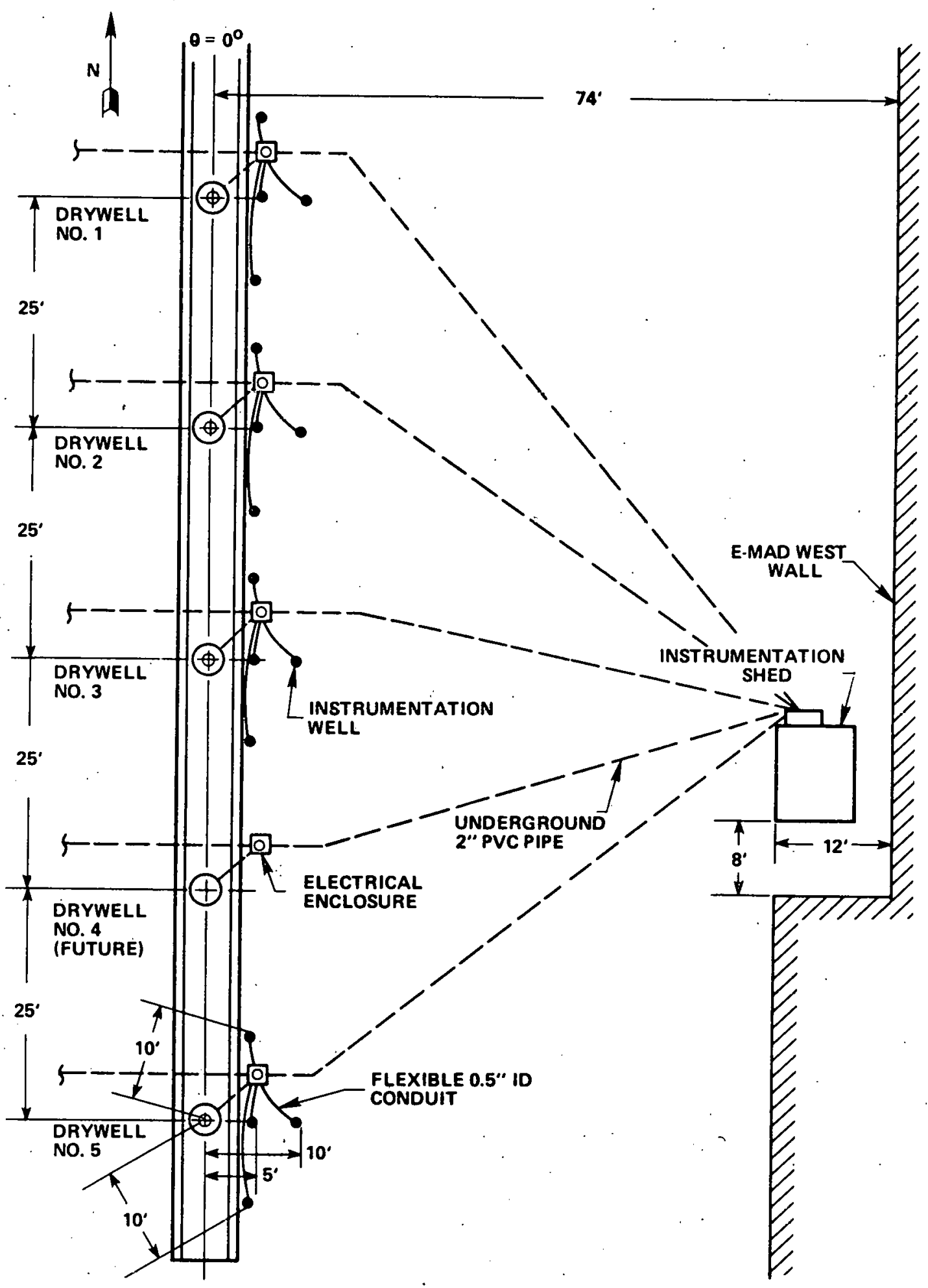

705430.78

Figure 14. Drywe11 Storage Area Configuration 
The northernmost drywell form was placed 120 feet from the north end of the pad. Second, 20 inches of concrete was poured in which were set 1.0 inch diameter studs every 6 feet to support the two rail tracks. Next, the two tracks were installed on 6 inch wide by 12 inch long by 0.5 inch thick plates which were placed over adjacent studs and supported by hex nuts threaded on the studs. The tracks were centered and leveled on the plates and secured using two rail clamps and hex nuts at each plate. The top 8 inches of concrete was poured level with the top of the two rails with 2 inch wide by 2.5 inch deep recesses on the inside of both rails to allow for the rail car wheels. Concrete pad construction is shown in Figures $A-2, A-3$ and $A-4$ in Appendix $A$.

Four drywell liners were installed for the SFHPP 1978 Demonstration. Twentysix inch diameter by 23 foot deep holes were drilled in the soi 1 for drywell liners using the three northernmost and the southernmost concrete pad holes for alignment and spacing. The spacing between the three northernmost drywells (25 feet) was chosen to provide test data for thermally interacting drywells whereas the southernmost drywell was placed 50 feet from an adjacent drywell. to thermally isolate it from the others. After each drywell hole was drilled, a 37.25 inch diameter by 9.25 inch high by 0.062 inch thick galvanized steel sleeve was installed in the lower portion of the roncrete pad to provide a. 3 ip plane between the grout installed around the liner and the concrete pad. The drywe 11 liner was then installed and leveled at the top to within \pm 0.03 inches. Grout was poured into the bnt.tom of the drywell hole until it reached a level about 1 to 2 feet above the bottom of the liner. After this grout set, the entire annulus between the liner and hole was filled to the top of the galvanized steel sleeve to provide an 18.75 inch deep recess at the top of the liner to allow for drywell shield adapter installation (see Section 4.8.2). Figure A-5 in Appendix A shows the drywell liner being lowered through the concrete pad prior to grout installation.

Each drywell has a cover plate which is bolted to the top of the concrete pad. The drywell cover plate is 46 inches in diameter by 0.25 inches thick and is made of carbon steel. Four lifting eyes are welded to the top of the cover 
plate to facilitate handling. A 41 inch outside diameter by 39 inch inside diameter by 0.25 inch thick neoprene gasket is cemented to the underside of the cover plate to seal the plate against the concrete pad. The cover plate has sixteen 0.625 inch diameter clearance holes for the 0.5 inch diameter by 1.25 inch long hex head bolts used to secure the cover plate to the concrete pad. Anchors are installed in the top of the pad to mate with the bolts. Four bolts. on each cover plate have a hole through the hex head which allows security wires to be placed through two pair of bolts on each drywell after the canister has been installed. The drywell cover plate is shown in Figure A-14 in Appendix A.

Prior to drywell concrete pad construction, underground pipe and conduit was laid to allow for instrumentation routing for three spurs of drywells. Fifteen lines of 2 inch diameter PVC pipe were installed approximately 2 feet below ground level running from the instrumentation shed to each of 15 drywe 11 locations including ten future drywell locations on proposed second and third rail spurs as shown in Figure 13. Vertical sections of metal conduit were installed at the end of each pipe to attach a large waterproof, dustproof electrical enclosure near each of the drywells. An additional five metal conduits were installed between the 37.25 inch diameter drywell pad recesses and the enclosure positions. The instrumentation conduit is connected to an environmentally controlled instrumentation shed located outside the E-MAD building (see Figure 14).

Four instrumentation wells (described in Section 4.6) and four electrical enclosures were installed near each of the four drywells. Figure 15 shows the location and orientation of the instrumentation wells for drywe lls number 3 and 5. Flexible conduit from each of these four wells was attached to the nearby electrical enclosure (see Figure 15).

\subsection{INSTRUMENTATION WELLS}

The soil surrounding each drywe 11 was instrumented with a total of 12 thermocouples divided and grouped into four instrumentation wells. The orientation 


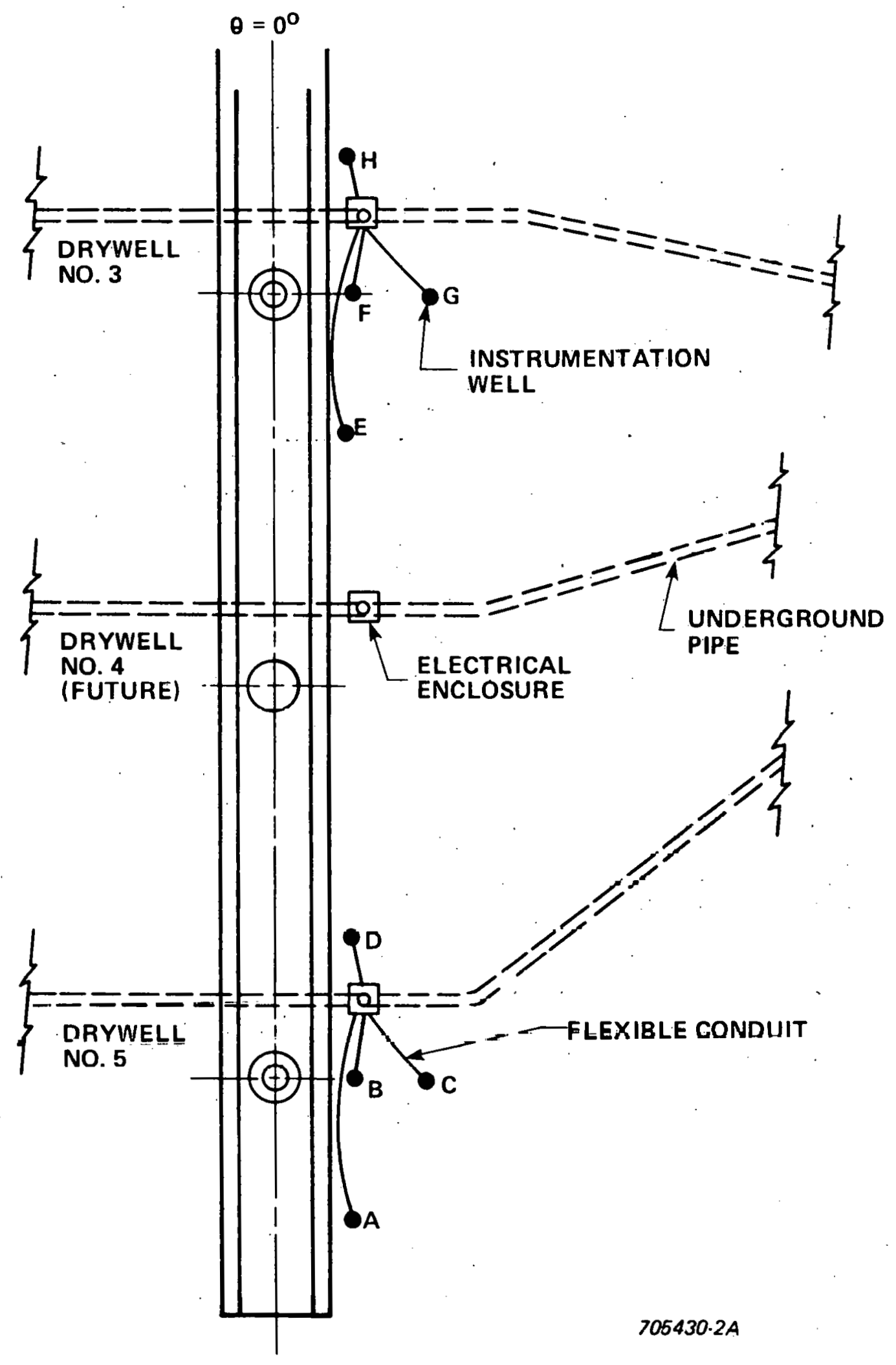

Figure 15. Drywell Number 3 and Number 5 Storage Area 
of the instrumentation wells is shown in Figure 15 for drywells number 3 and 5. Each instrumentation well consists of a 19 foot long 1.0 inch diameter schedule 80 PVC pipe. The sheathed thermocouples for each instrumentation we 11 were attached to the outside surface of the PVC pipe at three axial locations as shown in Figure 16. The thermocouples were attached using wire ties and epoxy patches spaced 12 inches apart. Table 1 provides the location data for each of the instrumentation wells and attached thermocouples.

Each instrumented pipe was inserted into a 3.5 inch diameter hole and grouted in place. The top of each pipe extended inches above ground level. At the top of each pipe, an enclosure box was provided and to attach a 0.5 inch inside diameter flexible conduit routed to the storage site instrumentation shed. The enclosure boxes were used to route the thermocouple leads through the flexible conduit after installation of the well and conduit. Figures $A-6$ and $A-7$ show thermocouple well installation activities.

\subsection{DATA ACQUISITION SYSTEM}

The data acquisition system for the Drywell Test consists of the array of thermocouples, a data logger, and a remote scanning/multiplexing unit. The thermocouples are attached to the test hardware as described earlier in this section of the report. The thermocouple leads are routed to sealed electrical enclosures and to the multiplexer unit located in the instrumentation shed outside the E-MAD west wall. Multiplexer signal cables are routed through underground. conduit to the data logger which is located inside the E-MAD building in the West Operator Gallery.

\subsubsection{THERMOCOUPLES}

Al1 thermocouples used in the Orywell Test described in the previous sections consist of a Type $K$, chromel-alumel thermocouple with ungrounded junction enclosed in a 304 stainless steel sheath. The canister and liner thermocouples have a 0.062 inch diameter sheath and the Instrumentation Well thermocouples have a 0.125 inch diameter sheath. Two 24 gauge Type $K$ extension wires are brazed to the thermocouple wires and are enclosed in a 0.187 inch diameter by 


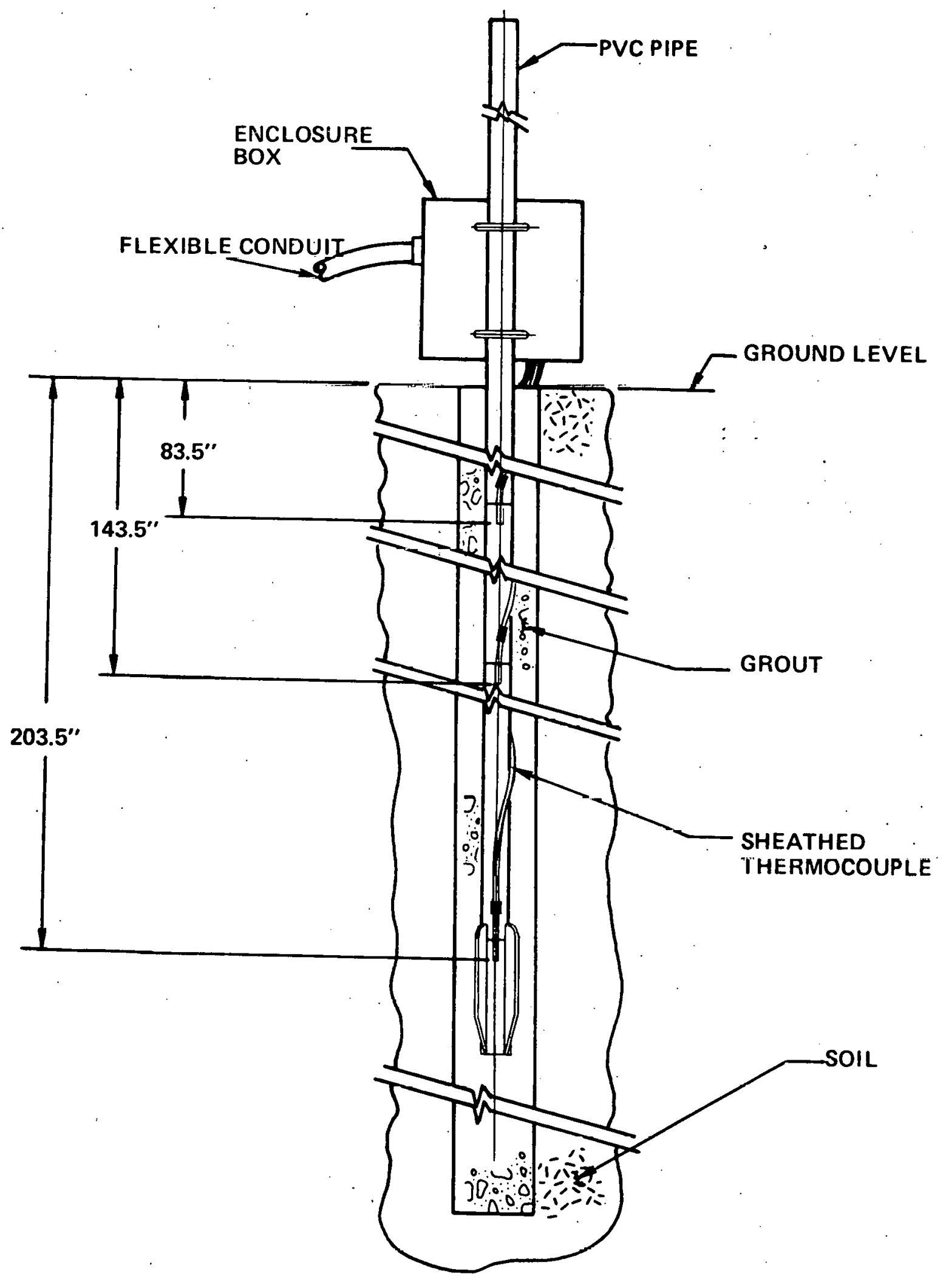

615440-7A

Figure 16. Instrumentation Well Configuration 
0.025 inch wall by 2.75 inch long stainless steel transition boot. The transition boot is crimped onto the end of the thermocouple cable sheath and filled with epoxy. Heat shrink tubing is installed on the Instrumentation Well thermocouples transition boot and a length of the extension wires to provide additional moisture protection for the portion of those thermocouples installed underground. Table 1 provides the identification and location data for all the thermocouples installed in and around drywells number 3 and 5 . Figure 17 shows the typical drywell thermocouple elevations.

\subsubsection{DATA LOGGER SYSTEM}

An Acurex Autodata IX data logger with one remote scanning/ multiplexing unit is used for the Drywell Test. The data logger is shown in Figure A-15 in its installed configuration. The data logger is also used for other experiments at E-MAD (Soil Temperature Test, Surface Storage Cask fueled storage cell and Fuel Temperature Test) and for monitoring spent fuel temperatures with in the E-MAD hot cells. The data logger operates on 120 volt, $60 \mathrm{~Hz} \mathrm{AC}$ electrical power and is rated for operation in the range of $32^{\circ} \mathrm{F}$ to $110^{\circ} \mathrm{F}$ and 0 to 90 percent relative humidity. This data logger system was selected with capabilities to meet the test needs of the SFHPP 1978 Demonstration with considerations for future expansion. Some of the capabilities being utilized for the Drywell Test are as follows:

- Measurement of Type $K$ thermocouple temperatures from up to 1000 thermocoup les.

- Thermocouple open detection circuit (to determine failures).

- Remote signal conditioning and multiplexing for remote instrumentation up to 5000 feet from data logger mainframe.

- Console digital readout in identified engineering units (selectable on the front panel).

- Printer for output data with header and engineering unit identification. 


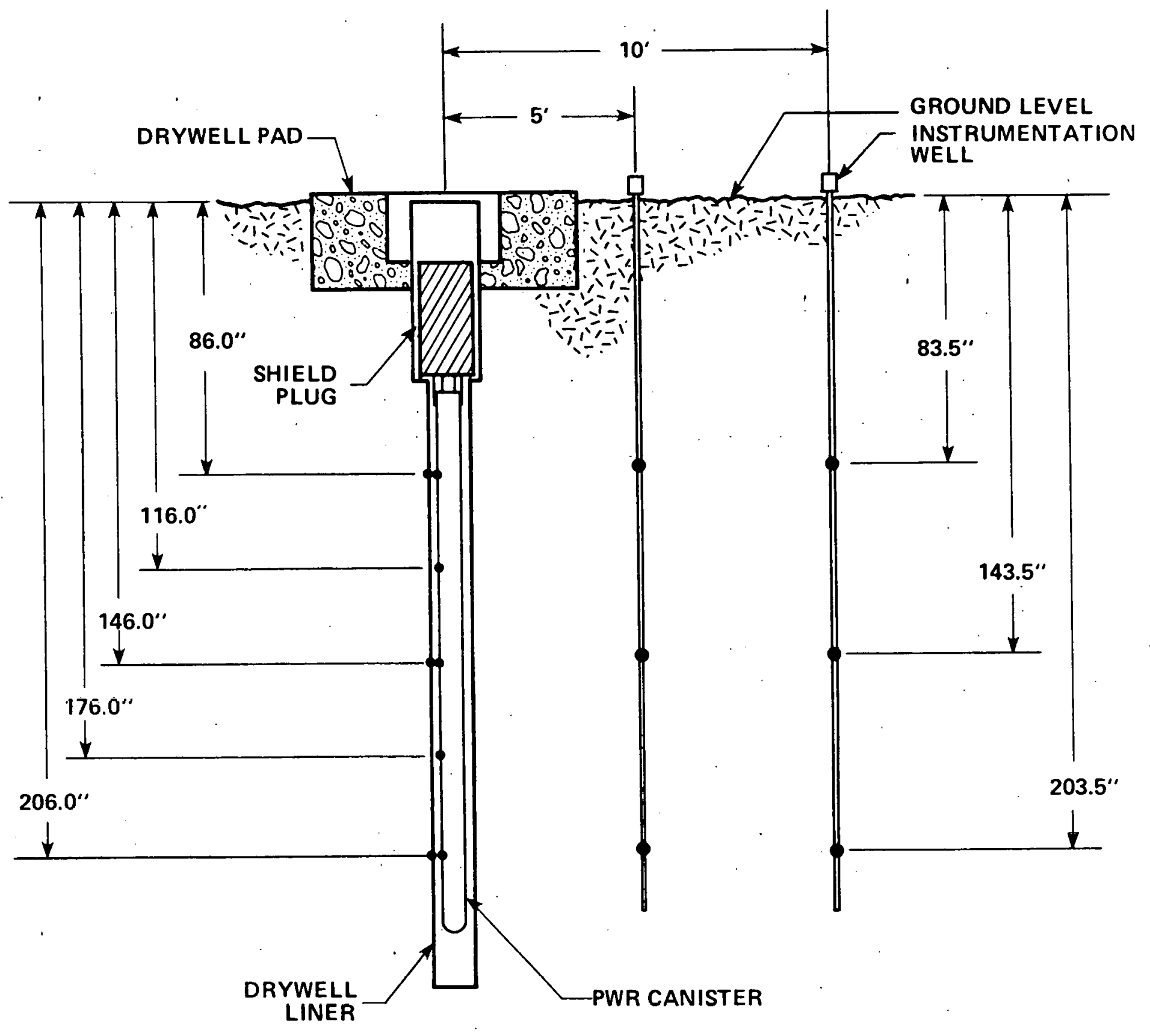

- THERMOCOUPLE LOCATIONS

$705430.1 A$

Figure 17. Typical Drywell Thermocouple Elevations 
- Variable scan modes (single, continuous, and intervals) with adjustable scan intervals.

- High performance analog to digital conversion.

\subsection{DRYWELL CANISTER EMPLACEMENT EQUIPMENT}

\subsubsection{TRANSFER SHIELD}

The transfer shield shown in Figure 18 is used to transfer the canister/shield plug assemblies from the transfer pit in the Hot Bay to the drywells in the storage area. The transfer shield is mounted on the Engine Installation Vehicle (EIV). The transfer shield provides personnel radiation shielding during transfer operations. Motive power for the transfer shield and EIV is provided by the Manned. Control Car and the L-3 locomotive. Movement of the train comprised of these three vehicles is controlled from the Manned Control Car. The transfer shield and three rail vehicles are shown in Figures A-10 to A-12 in Appendix A. These vehicles are described in Reference 1.

The transfer shield/EIV assembly has the following features:

- A drive system on the EIV that can move the shield vertically, longitudinally, and laterally with respect to the EIV.

- A winch to raise and lower the canister/shield plug assembly.

- A foot value to open and close the bottom of the shield to permit pickup and discharge of a canister assembly while providing shielding during transport.

- An electrical control system to prevent operator error and damage to equipment or exposure of personnel to excessive radiation levels.

The transfer shield assembly consists of two concentric carbon steel cylinders with the 6.5 inch annular space between the cylinders filled with 0.030 inch to 0.045 inch diameter lead shot. The lead shot is installed from the top of the shield annulus and is vibrated and tamped into place. The void space in the lead shot is filled with neutron absorbing shielding oil. The total shield 


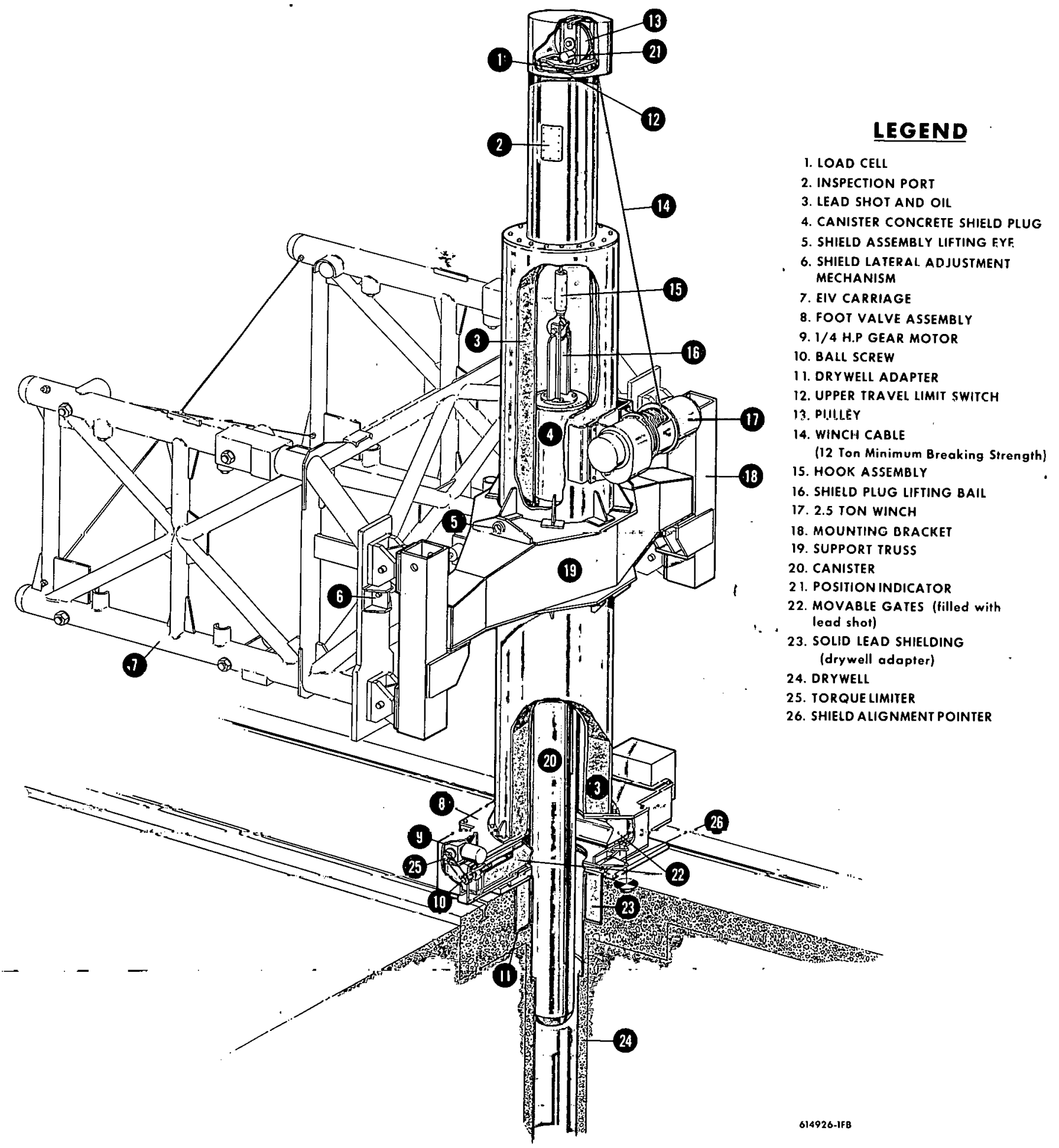

Figure 18. Transfer Shield/Canister Installation Configuration 
assembly is approximately 25 feet high and.3 feet in diameter. A rectangular foot valve assembly extends approximately 3 feet on either side of the vertical centerline. The transfer shield weighs approximately 50,000 pounds.

The shield support truss is attached to existing mounting holes on the carriage. of the EIV. The EIV has vertical, longitudinal, and lateral carriage drives which are used to position the shield with respect to the transfer pit and drywell.

The transfer shield winch and cable assembly are designed to raise and lower a canister and shield plug having a combined weight of approximately 4000 pounds. The winch, with a rated capacity of 2.5 tons, is an electric motor driven hoist attached to the side of the shield assembly. The cable is a $6 x$ 37 class, steel core, high strength, steel cable which has a breaking strength greater than 12 tons. The cable is routed from the hoist drum to the top of the shield assembly, around a 11.75 inch diameter sheave, and then into the transfer shield interior to the hook assembly. The hoist has the capability for hand crariking for raising or lowering a canister assembly in the event of power failure.

The foot valve assembly consists of two gates which are filled with 8.3 inches of lead shot. A " $V$ " shaped interface between the gates limits radiation streaming during canister assembly transport. Each gate in the foot valve, supported by cam rollers, is individually driven by a $1 / 4$ horsepower electric motor (with gear reducer) connected by a chain drive to a ballscrew. Limit switches control the travel of the two gates and a slip clutch is provided to protect the mechanism in the event of a limit switch malfunction. The foot valve gates also have the capability for hand cranking in the event of power failure.

An electrical control system is provided to permit remote operation of the EIV and the transfer shield components. Control panels are provided in the Manned Control Car (MCC) Cab and at the back end of the EIV (opposite end of the EIV 
from the shield). A third portable control panel can be used to operate the system from the E-MAD gallery when the EIV is located in the Hot Bay. Operation is normally from the MCC panel. The electrical control system has provisions to limit winch and foot valve travel, to limit shield travel via the EIV carriage motion mechanisms, and to interlock operating modes to prevent inadvertent winch, foot valve, or shield motions from causing exposure of personnel to a bare (unshielded) canister assembly. A series of sensing switches are provided on the transfer shield and EIV to indicate load on the cable, winch hook full up and down position, shield full up and down position, foot valve open and closed position, and EIV lateral and longitudinal travel limit positions.

The details of transfer shield/EIV transfer operations are provided in Reference 1.

\subsubsection{DRYWELL SHIELD ADAPTER}

A special shield adapter is installed in the annular region around the upper drywell liner during canister assembly emplacement and removal operations. This drywell shield adapter limits radiation levels in the area immediately surrounding the drywell while the canister is being raised or lowered. The drywell shield adapter is illustrated as installed in the drywell in rigure 19.

The drywell shield adapter is made of carbon steel and consists of two 17.5 inch long concentric pipes having a 22.5 inch inside diameter and a 36 inch outside diameter. The 5.75 inch wide annulus between the pipes is filled with lead shot which was vibrated and tamped in place. A 0.5 inch thick bottom plate and a 2 inch thick top plate are welded to the two pipes. The top plate is 49 inches square and has a 1.0 inch deep by 39 inch diameter recess machined in the top to interface with the bottom of the transfer shield. Four 1.5 inch diameter rods, which were welded to the top and bottom plates to provide additional support, each have 0.5 inch diameter threaded holes which are fitted with lifting rings for handling the shield adapter. The adapter weighs approximately 4000 pounds. 


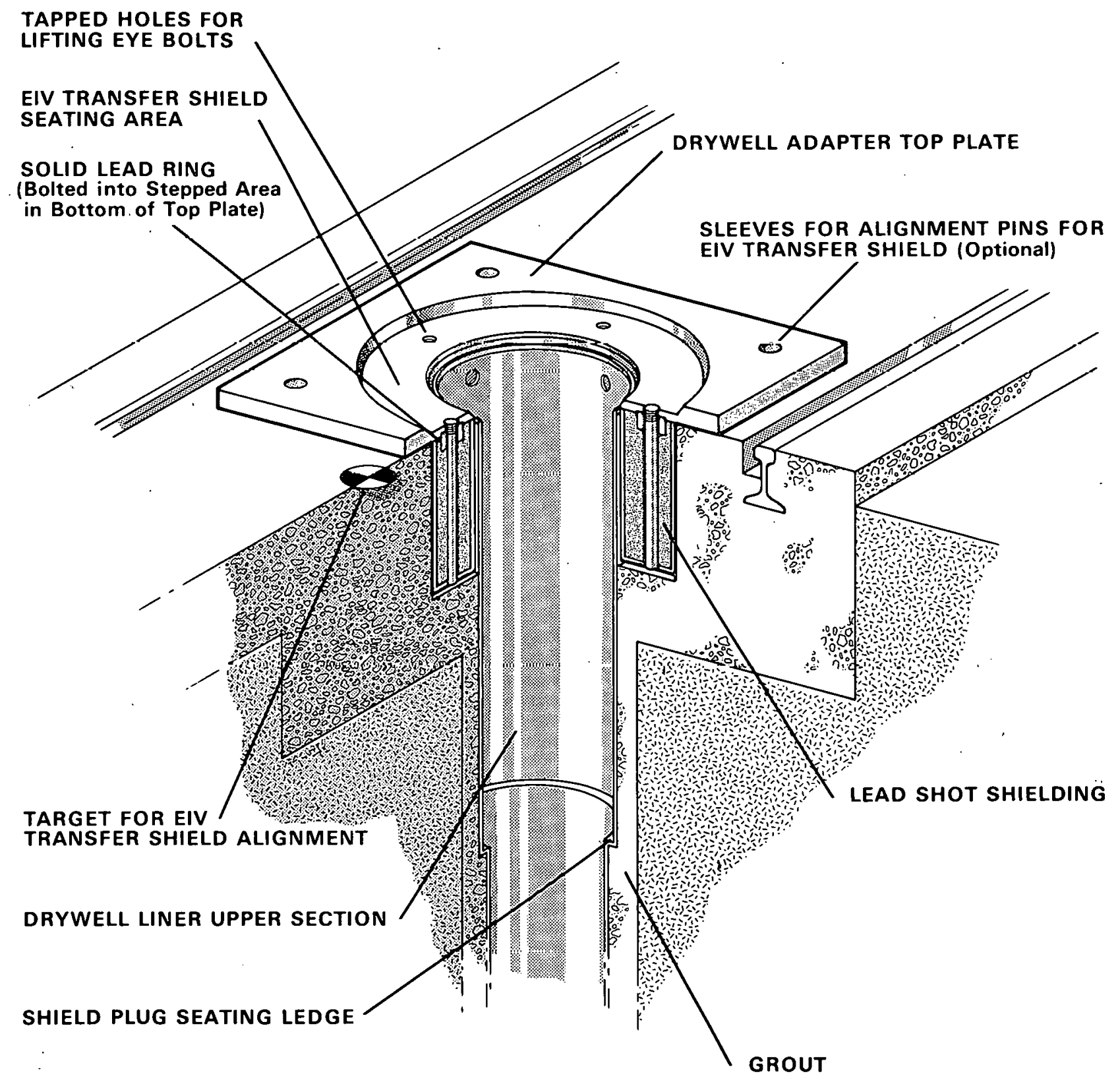

Figure 19. Drywell Shield Adapter Configuration (Shown Installed in Drywell) 


\subsection{TEST OPERATIONS AND RESULTS}

\subsection{TEST OPERATIONS}

\section{1 .1 CONSTRUCTION}

The drywell storage area construction was completed in September, 1978. Four drywell liners were installed in positions 1, 2, 3, and 5 (drywell positions numbered from north to south, see Figure 14). The drywell liner positions wcre chosen based on the initial thermal analyses to provide one thermally isolated drywell (50 feet from adjacent drywe11) and three drywells which would provide. test data on drywell thermal interactions.

Storage area instrumentation well installation was completed in October, 1978. Sixteen instrumentation wells were installed with four wells near each of the four installed drywell liners. After the instrumentation wells were installed, the 19 canister and liner thermocouples for each drywell were coiled and placed in the adjacent electrical enclosures. The thermocouple leads for each drywell and adjacent four instrumentation wells were bundled together and routed from the electrical enclosures to the multiplexer unit. in the instrumentation shed through the underground pipes installed in the storage area.

\section{1 .2 FUEL ASSEMBLY ENCAPSULATIION}

Isolated Drywell Test spent fuel assembly encapsulation operations occurred during the second and fourth weeks of January, 1979. The following presents a brief summary of the typical E-MAD encapsulation operations performed. Further details of the operations and equipment are found in Reference 1. The operations began with the spent fuel shipping cask preparation for fuel assembly unloading. Using the vendor supplied lifting yoke and E-MAD overhead crane, the cask is upended, lifted, and placed in the cask work platform. Hands-on cask operations include installation of the cask vent line, removal of lifting yoke, removal of closure lid holddown bolts, attaching the lid lifting fixture, and venting of the cask internal pressure through the ventilation system north stack. 
After the cask is ready for fuel unloading, operations are performed remotely. The cask closure lid is removed and placed on its stand. The fuel handling tool is inserted in the cask, the tool fingers are engaged, and the handling tool and fuel are lifted by the overhead crane. Once out of the cask, each fuel assembly is visually examined along the full length of each side by a remotely held TV camera. The fuel is then placed in a canister located in the Hot Bay weld pit (Figure A-8), the fuel handling tool disengaged and replaced on its stand. The canister thread protector is removed, and the threads are inspected and cleaned, if required. The closure lid is placed on the canister and torqued down by the large Wall Mounted Handling System (WMHS). The welding head is placed on the canister and secured prior to canister seal welding.

The weld is made remotely and the completed weld visually inspected using a wall mounted periscope. The welding head is then removed by the WMHS and placed on a stand. The canister is evacuated and backfilled with helium utilizing the evacuation and backfill system which is remotely connected to a fitting on the closure lid. When backfilling is complete, the hose is remotely disconnected and a plug fitting installed. The leak check system vacuum chamber hood is placed over the weld pit by the WMHS, and the vacuum chamber is evacuated by the evacuation system attached to the lower part of the chamber. A sample is drawn from the vacuum chamber into a helium leak detector in the gallery and examined for helium. The vacuum chamber hood is removed and placed on its stand and the sealed and leak checked canister is ready for storage. The shield plug is placed on the canister by the overhead crane and secured in place. The canister and shield plug are moved to the survey pit where swipes are made of the canister surface using the master-slave manipulators. The swipes are removed from the Hot Bay using the pass-through drawer. The swipes are checked for contamination and the canister decontaminated, if necessary. Prior to transfer to the storage site, the canister and shield plug are moved to the transfer pit and lowered into place as shown in. Figure A-9 in Appendix A. 


\subsubsection{TRANSFER TO THE DRYWELL}

Prior to transferring the canister to the drywell, a special lifting bail is installed on the shield plug in the transfer pit. The Engine Installation Vehicle (EIV) and transfer shield are moved into the Hot Bay by the Manned Control Car and L-3 locomotive and centered over the transfer pit as shown in Figure A-10. The shield foot valve is opened and the transfer shield hook assembly lowered remotely. The hook is engaged on the lifting bail and the shield lowered until it seats on the top of the transfar pit. The canister dild shield plug are then raised into the transfer shield, the fout valve closed, and transfer shield raised prior to removing the rail vehicles, shield and canister from the Hot Bay. The drywell shield adapter is installed in the drywell prior to canister movement to the storage ared. The rail vehicles move the transfer shield and canister assembly out to the storage site and then maneuver the transfer shield to a position directly above a drywell. The transfer shield is lowered until it seats on top of the drywell shield adapter as shown in Figure $A-11$. The foot valve is opened and the canister lowered into position in the drywell. After the transfer shield is raised, the hook is removed and raised into the shield, the foot valve closed, and the rail vehicles moved to a parking location. Figure A-12 shows the transfer completed in Drywell 5. To complete the drywell operations, the drywell shield adapter is removed using a mobile crane, the lifting bail removed, the thermocouplcs inserted thruugh the shield plug and liner as shown in Figure $A-13$, the instrumentation connections made at the multiplexer unit, and the cover secured over the drywell.

The first canister assembly containing fuel assembly Serial Number B03 was installed in Drywell 5 on January 12, 1979. The second canister assembly containing fuel assembly Serial Number 841 was installed in Drywell 3 on January 24, 1979. Thermocouples for both drywel1s were attached to the multiplexer and a set of reference temperature readings were taken prior to thermocouple insertion. 


\subsubsection{TEMPERATURE MONITORING}

Temperature data from the two drywells have been monitored from their dates of emplacement. For each drywe11, data logger printouts were made every hour for the first day, every four hours for the next six days and twice a day thereafter at 4:00 a.m. and 4:00 p.m. In May 1979, the printouts were made at 8:00 a.m. and 4:00 p.m. and continued at those times throughout the remainder of the test period. Appendix $B$ provides temperature readings recorded by the data logger for Drywells 3 and 5 at two week intervals. Table 1 provides a listing of thermocouple positions and data logger data channels used to read out the temperature data.

\subsubsection{SUBSEQUENT REPAIR ACTIVITIES}

Following drywell emplacement operations, repair activities pertinent to the Isolated Drywe 11 Test and its data occurred.

During thermocouple routing from the electrical enclosure to Drywel1 5, one of the liner thermocouples (T/C 877) was broken. A replacement thermocouple was installed in the liner thermocouple tube and a Type $K$ thermocouple connector was used to join the replacement thermocouple extension wire and the existing wire leading to the instrumentation shed. This connection was made in the electrical enclosure. It was later determined that the replacement thermocouple was 60 inches longer than it should have been. This information has been noted on Table 1 .

During thermocouple installation activities for both drywells, it was noted that some of the pad concrete in the area of the drywell.cover gasket had cracked or was broken and that a good seal between the gasket and concrete would not occur. Some of the broken concrete at Drywell 5 is visible in Figure A-13. The top of the pad was repaired using epoxy grout which provided a 53 inch square by 1.0 inch high raised area on the top of the pad. Drywell 5 concrete pad repairs were completed on January 22, 1979, and Drywell 3 concrete pad repairs were completed on February 12, 1979. 
Two liner thermocouples failed during the Isolated Drywell Test. Data readings from Drywe 113 liner thermocouple 829 greatly differed from the similar position thermocouples ( $T / C 876$ and 878 ) soon after thermocouple installation (no irregularity in reading had been noted during the initial temperature readouts). Following an integrity check, this thermocouple was removed and replaced on March 16, 1979. A Type K thermocouple connector was used to join the replacement thermocouple with the extension wire connected to the data logger system multiplexer. Later in the test on February 15, 1980, Drywe11 3 liner thermocouple 828 stopped providing data. After an integrity check, this thermocouple was found to have failed and was disconnected. Since no replacement thermocouple was available, further data readings from this channel were not taken.

Following canister thermocouple installation, an evaluation of the canister thermocouple tube/thermocouple interface was conducted due to the fact that the thermocouple transition boots, which should have been about 6 inches above the top of the shield plug when the thermocouple end contacted the bottom of the canister tube, were in contact with the top of the shield plug. The evaluation showed that the ten canister thermocouples could pass between the canister and thermocouple tube angle and plate, and in fact, may be measuring air temperatures between the canister and liner. It was determined that the thermocouples should be raised so that the transition boots were about 5.5 inches above the top of the shield plug. This was accomplished on April 30, 1979. The test data results presented in the next section and in Appendix C. show that the temperatures from all 20 canister thermocouples were affected by this action indicating that the thermocouples were outside the canister tubes. Due to a communication problem, the nine liner thermocouples for each drywell were also raised by 5.5 inches on April 30. An evaluation of the liner temperature. versus time curves shortly thereafter revealed the change in thermocouple position. The liner thermocouples were reinserted to their proper position on May 22, 1979. 


\subsection{TEST RESULTS}

This section presents the thermal test tesults for the isolated drywells (numbers 3 and 5) from drywell and soil thermocouples (thermocouple channels and positions are identified in Table 1). Thermal test results are shown in Figures 20 to 27 with all temperature data being shown in Figures $\mathrm{C}-1$ to $\mathrm{C}-12$ in Appendix $C$.

The peak measured temperatures for Drywe 113 are presented in the form of canister, liner, and soil temperature distributions throughout the test period in Figure 20 and as canister and liner axial temperature profiles in Figure 21. Figures 22 and 23 present the peak measured temperatures for Drywell 5. The peak temperatures occurred several inches below the canister midplane during August 1979. For Dryweil 3, the peak canister temperature was $254^{\circ} \mathrm{F}$, and the peak liner temperature was $198^{\circ} \mathrm{F}$. For Drywell 5, the peak canister temperature was $253^{\circ} \mathrm{F}$, and the peak liner temperature was $203^{\circ} \mathrm{F}$. After the peak temperatures occurred, all temperatures decreased and began a cycling pattern in response to seasonal atmospheric temperature changes. If data were recorded over a period of several years, the temperatures would continue showing seasonal cycles superimposed on decreasing mean temperatures which result from the gradually decreasing decay heat level.

Also shown in Figures 20 and 22 are soil temperatures measured at the Soil Temperature Test Reference Well. The Reference Well is positioned 60 feet from the Soil Temperature Test, nearly 100 feet from Drywell 5 and 150 feet from Drywell 3. These distances are sufficient that Reference Well soil temperatures would not be affected by the drywell tests or the Soil Temperature Test. Therefore, the Reference Well data provide a valid base from which the thermal effect of drywell operation on near-field soil temperatures can be ascertained. In addition, they provide data illustrating the influence of seasonal changes on soil temperatures at the various thermocouple depths.

During the initial testing period (January 1979 thorugh April 1979), canister thermocouples were positioned incorrectly on both drywells as previously 


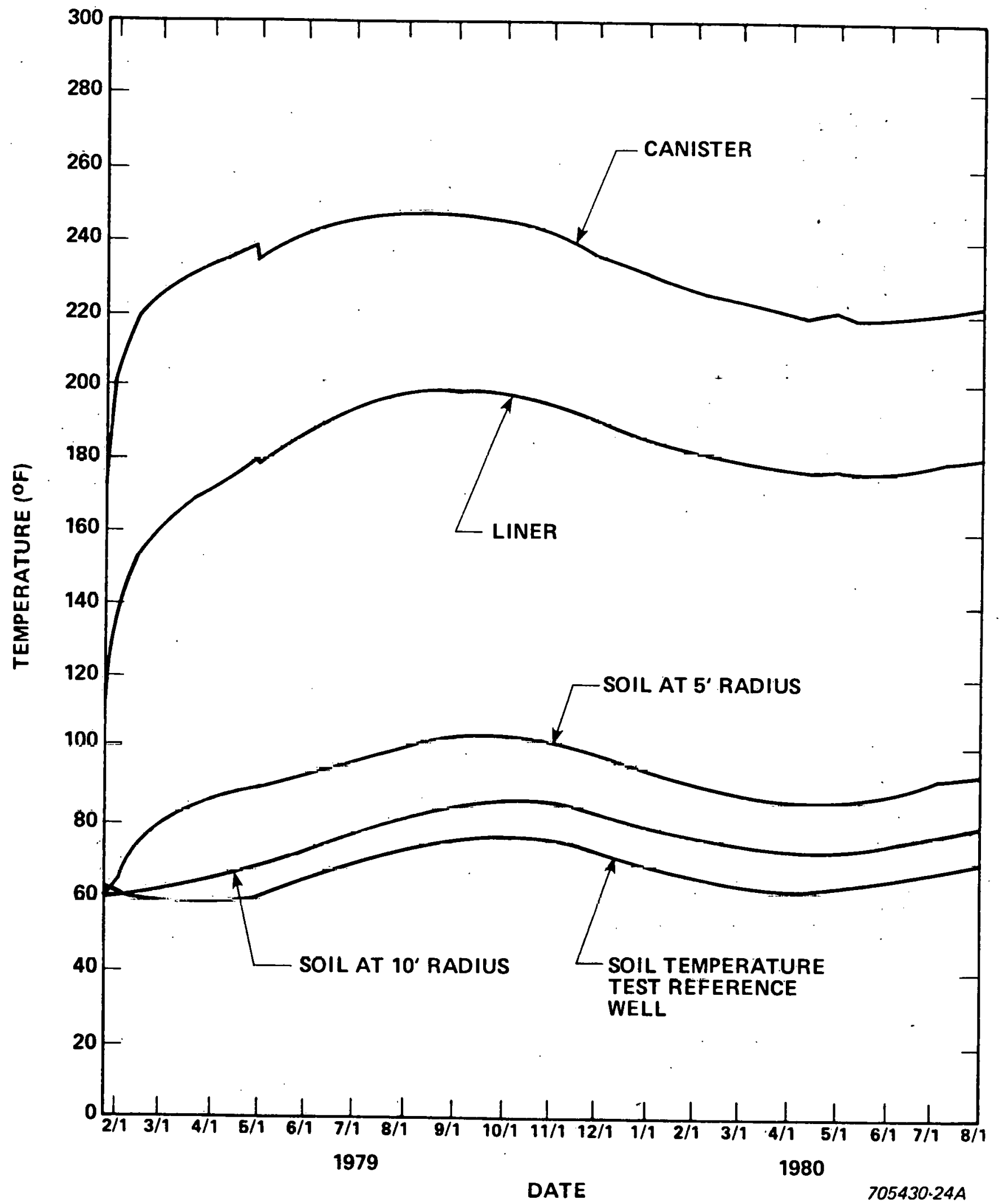

Figure 20. Drywell 3 Peak Canister, Liner and Soil Temperature Distributions 


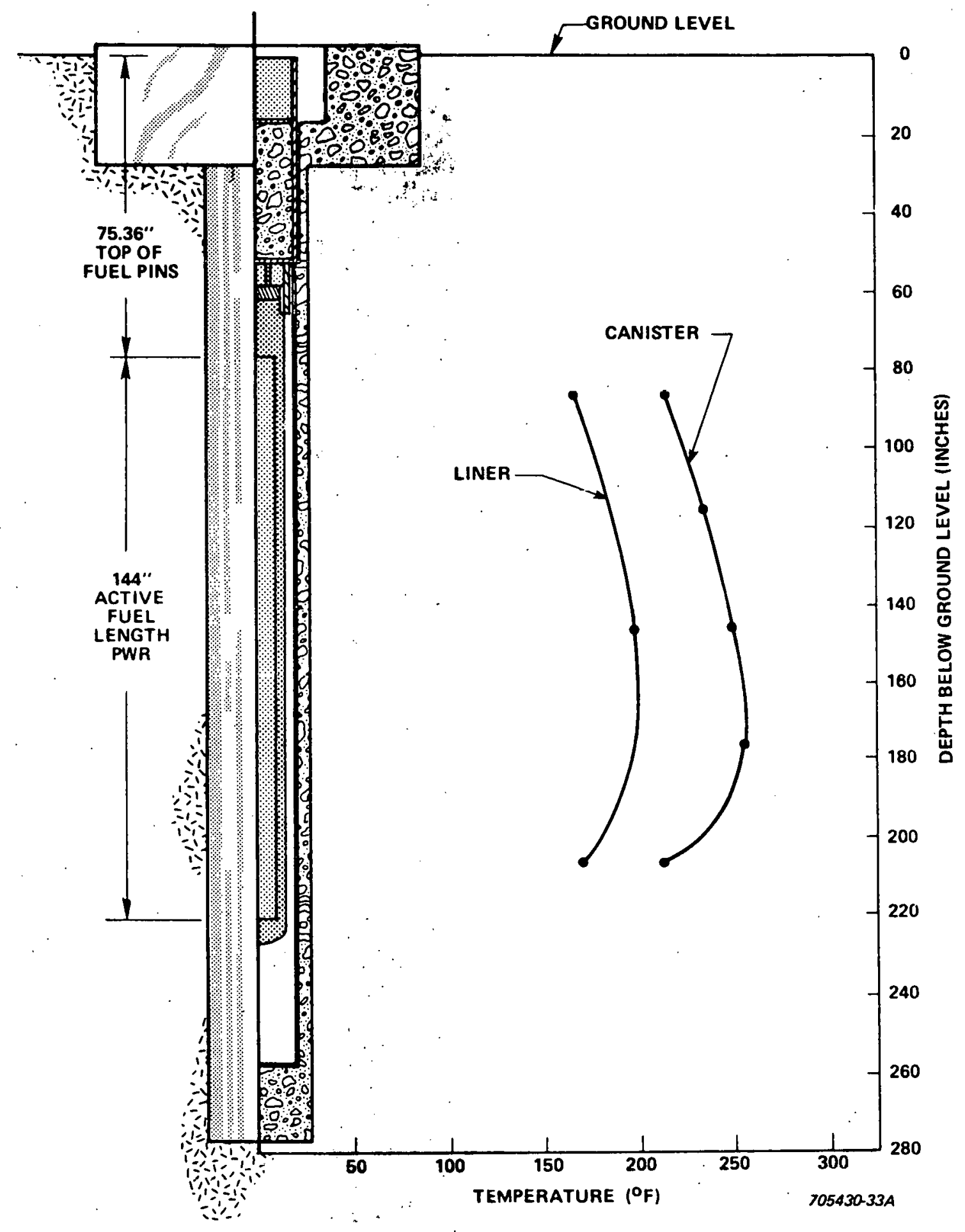

Figure 21. Drywell 3 Peak Canister and Liner Axial Temperature Profiles 


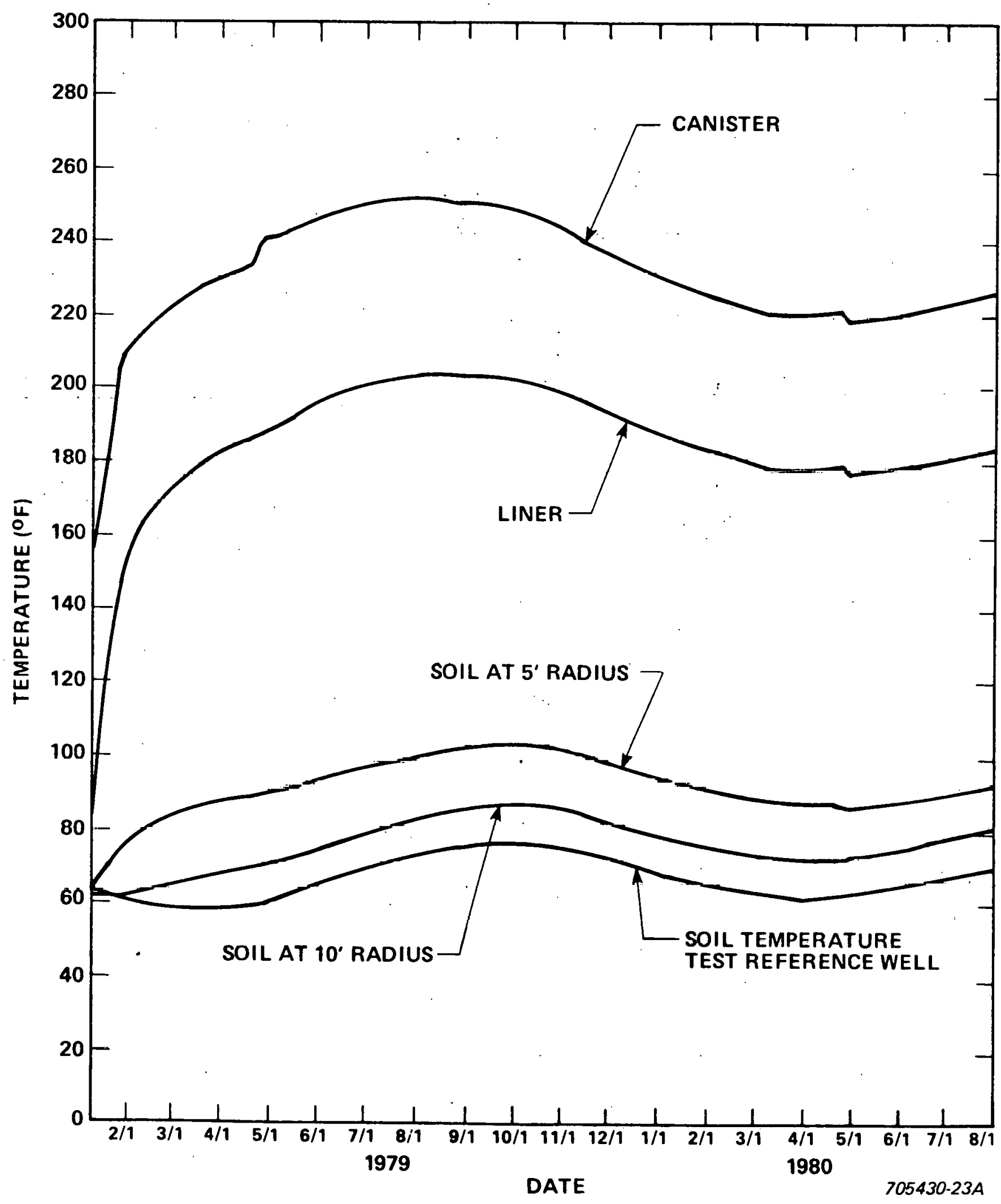

Figure 22. Drywel1 5 Peak Canister, Liner and Soil Temperature Distributions 


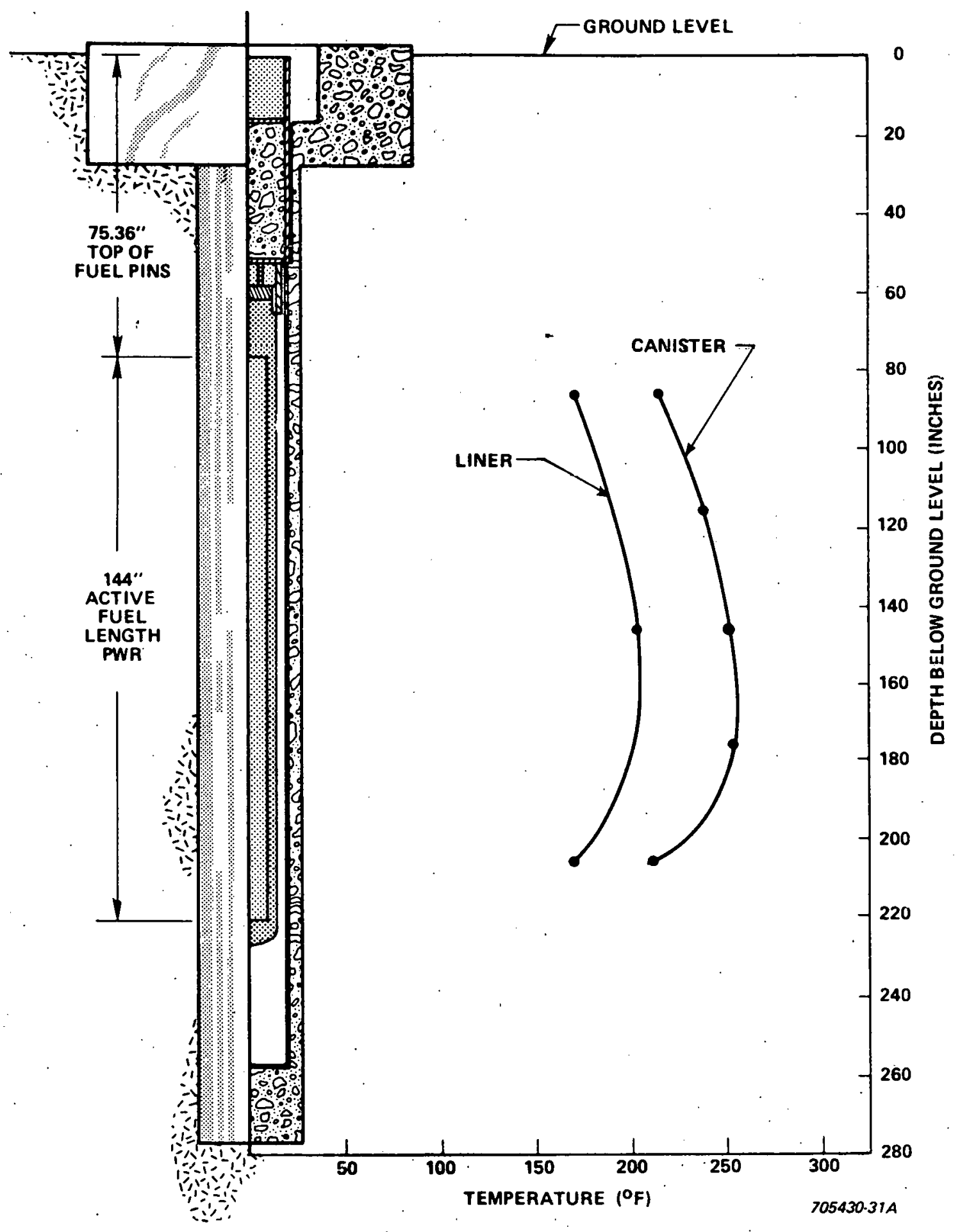

Figure 23. Drywell 5 Peak Canister and Liner Axial Temperature Profiles 
noted. The effect of the thermocouples being outside the instrumentation tubes accounts for the large early differences between canister temperatures at several elevations and also accounts for the abrupt temperature changes recorded on April 30, 1979, when thermocouple position adjustments were made. For the test period after Apri1, 1979, the temperature versus time curves show small $\left(10^{\circ} \mathrm{F}\right.$ or less) circumferential temperature variations at all instrument elevations. In addition, a comparison of the four Drywell 5 liner thermocouples at an elevation 205 inches below ground level showed a variation of less than $2^{\circ} \mathrm{F}$ until about March 1, 1980 when one of the thermocouples (867) varied between $3^{\circ} \mathrm{F}$ and $6^{\circ} \mathrm{F}$. This information indicates that uniform soil properties exist circumferentially; and, concerning the soil temperature data particularly, it shows no thermal effect of one drywell on another.

The effects of axial heat convection inside the canister were evident in Drywells 3 and 5 . Convection effects within an air filled canister were evident in the Soil Temperature Test data as discussed in Reference 2. It was noted there that convection currents could cause canister temperature variations at one elevation to occur more rapidiy due to temperature changes at other elevations than would be possible by conduction heat transfer alone. Thus, canister temperatures at two different elevations tended to be more closely in phase than soil temperatures at the same elevations. The same phenomenon is apparent in data from Drywells 3 and 5 . Comparing canister temperature data from three elevations on Drywe 113 in Figure 24 with soil temperature data at a 10 font. radius in Figure 25 for the same elevations, the canister traces all peak within a period of approximately 30 days, while the soil temperature peaks are distributed over a period of 60 to 70 days. This is also the case for Drywell 5 as shown by comparing the canister and soil data in Figures 26 and 27.

The thermal data from Drywells 3 and 5 showed that the day-night atmospheric temperature changes had little or no effect on the drywell temperatures. Comparing the temperatures of the canister, liner, and soil at the 5 foot and 10 foot radius at the uppermost thermocouple elevation showed a maximum $0.5^{\circ} \mathrm{F}$ difference between the early morning and mid-afternoon data recordings. 


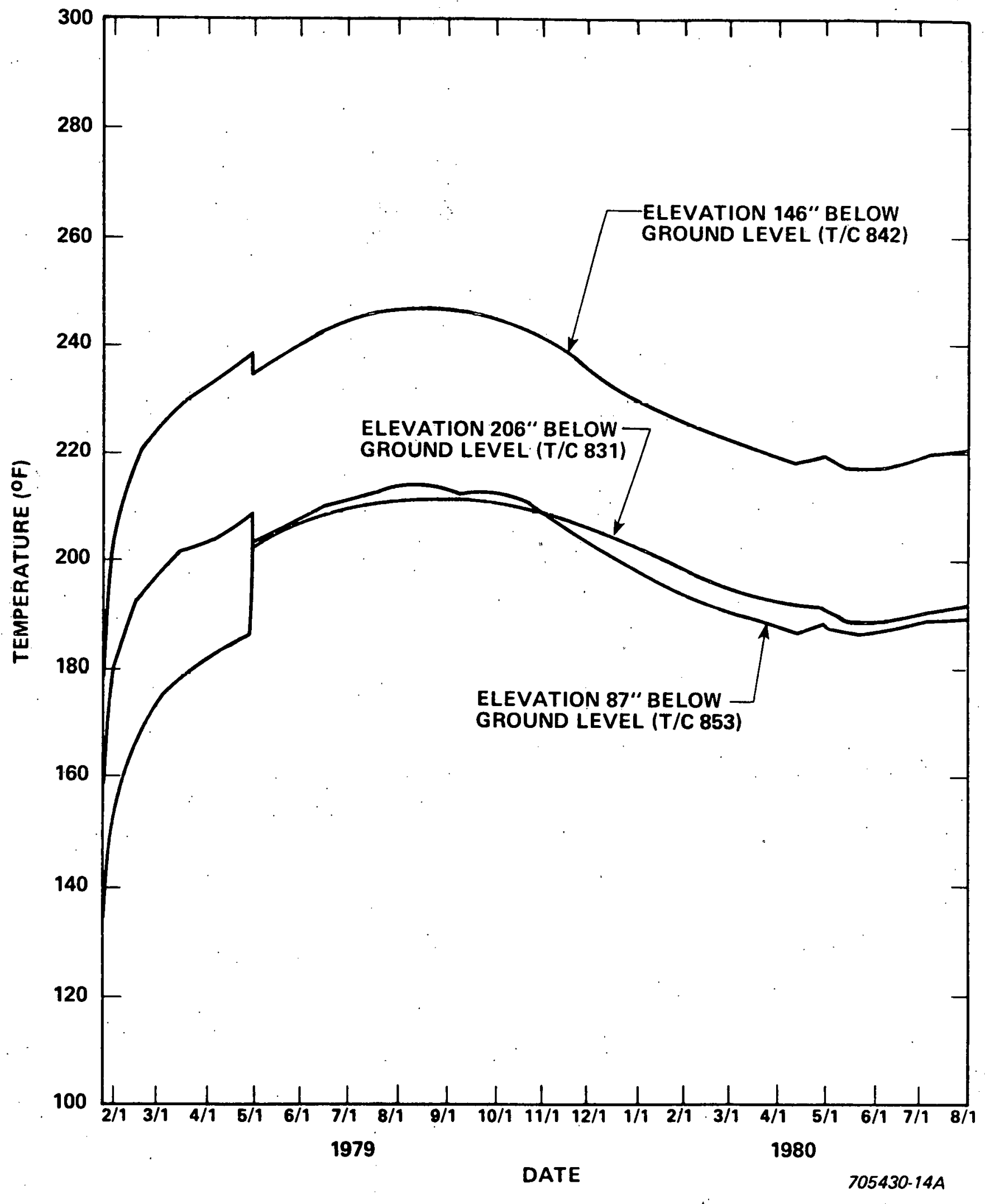

Figure 24. Drywe11 3. Canister Temperature Distributions 


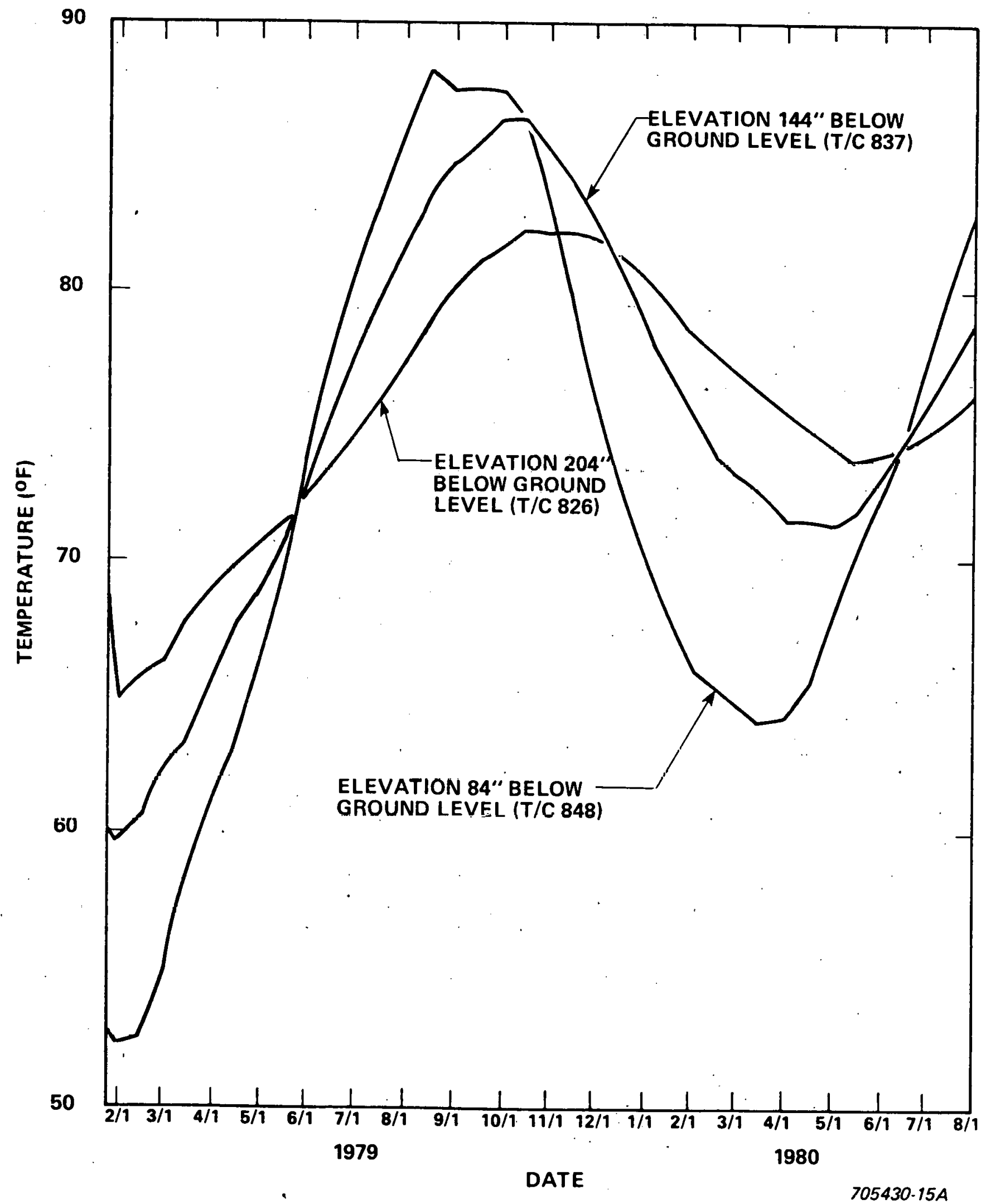

Figure 25. Drywell 3 Soil Temperature Distributions 


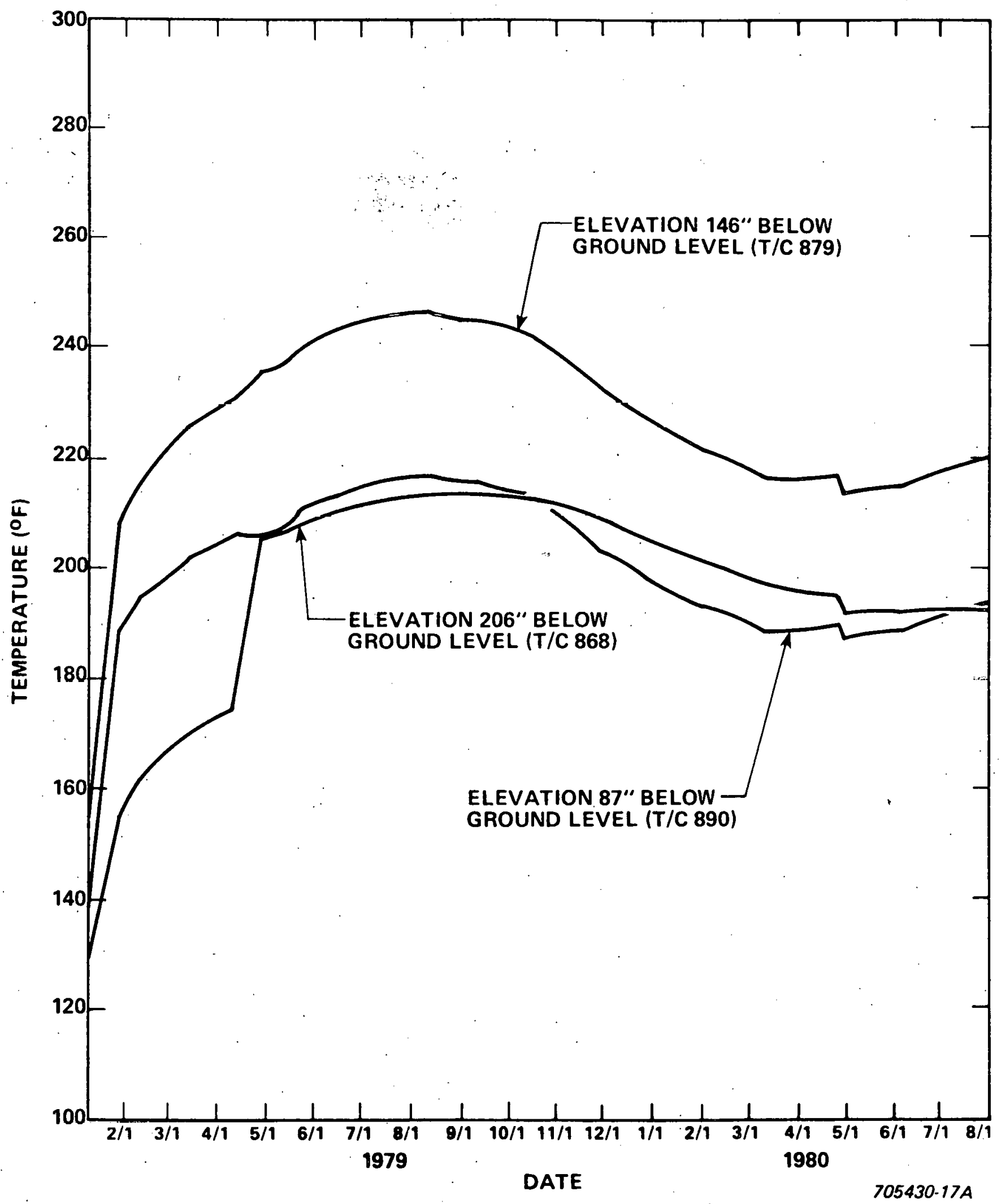

Figure 26. Drywell 5 Canister Temperature Distributions 


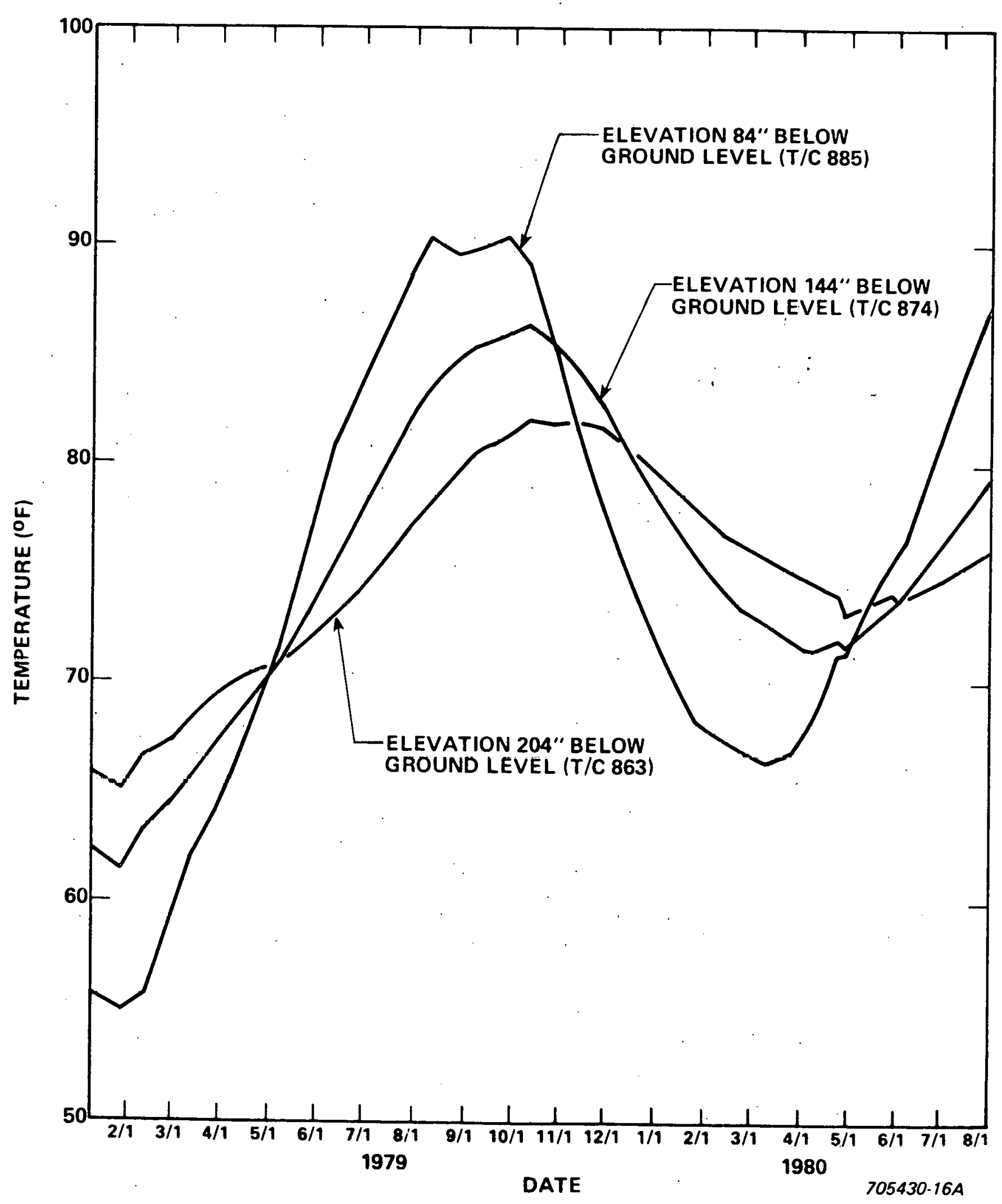

Figure 27. Drywell 5 Soil Temperature Distributions 
Figures $\mathrm{C}-1$ to $\mathrm{C}-12$ show plots of all the temperature data measured for both drywells. Figures $\mathrm{C}-1, \mathrm{C}-2$, and $\mathrm{C}-3$ show sets of canister, liner, soil, and Reference Well temperature data for the top, middle, and lower thermocouple levels, respectively, for Drywell 3. Figures $C-6, C-7$, and $C-8$ show the same data for Drywe 115 . Figures $C-4$ and $C-5$ present the canister temperatures measured at depths of 116 and 176 inches for Drywell 3 and Figures $C-9$ and C-10 present the same data for Drywell 5. Figures $\mathrm{C}-11$ and $\mathrm{C}-12$ show all the canister and liner temperature data in the form of axial profiles for Drywe 113 and Drywell 5, respectively. It should be noted that these data plots were generated by a computer code which provided straight lines between data points (except Figures $\mathrm{C}-11$ and $\mathrm{C}-12$ ) for data at two week intervals. Variations in measured data plotted, except for that from the thermocouple positioning change previously described, are suspected to be due to infrequent periods of heavy rainfall which occurred during the test period.

\subsection{ACCURACY OF TEST DATA}

Inaccuracies in test data recorded could be a result of thermocouple measurement inaccuracy and/or the position of the thermocouples inside the canister and liner tubes: The accuracy of the ungrounded Type $K$ thermocouples utilized in the Isolated Drywell Test is typically $\pm 2^{\circ} \mathrm{F}$ based on calibration data.

An examination of the Fuel Temperature Test data was made to evaluate the effect of having canister thermocouples inside the 0.75 inch by 0.75 inch angle instrumentation tubes. Four thermocouples were spaced around the Fuel Temperature Test canister at two separate elevations corresponding to 40 inches above and 30 inches below the fuel assembly active fuel midplane level. Two of the four thermocouples were attached directly to the canister and two were inserted into instrumentation tubes identical to those on the drywell canister (see Reference 3). Thermocouple data recorded for all of the helium backfill. tests run during Fuel Temperature Testing showed temperatures inside the tubes were lower than those on the canister surface by an average of between $2^{\circ} \mathrm{F}$ and $6^{\circ} \mathrm{F}$. This is expected to be the average inaccuracy in canister temperature measurements due to the instrumentation tubes. For the liner thermocouples, the close 
proximity of the thermocouple tube to the 1 iner wall and the geometry of a 0.062 inch thermocouple diameter inside a 0.083 inch inside diameter tube is expected to yield a smaller inaccuracy than for the canister thermocouples.

The overall test data recorded are judged to be within about $8^{\circ} \mathrm{F}$ of the actual canister temperatures, and within about $4^{\circ} \mathrm{F}$ of the actual liner and soil temperatures.

\subsection{POST-ISOLATED DRYWELL TEST OBSERVATIONS}

In addition to the Isolated Drywell Test described in this test report, other drywell tests have been planned. An isolated drywell test using a higher decay heat level fuel assembly and a drywell thermal interaction test using three of the four PWR fuel assemblies utilized in the SFHPP 1978 Demonstration were scheduled to begin in September, 1980. To accommodate these two tests, it was decided to rearrange the two existing drywells so that the canister assembly in Drywell 3 would be placed in Drywel1 2, and the canister assembly in Drywell 5 would be placed in Drywe11 3. Drywell rearrangement activities marking the end of the Isolated Drywell Test with $1 \mathrm{~kW}$ fuel assemblies occurred during the first week in August, 1980. Several observations which were made relative to the condition of Drywells 3 and 5 are discussed in the following paragraphs.

Each drywe 11 was inspected both before and after the two canisters were removed. Once the drywell covers were removed, it was noted that much of the epoxy grout $p$ laced above the concrete pad had cracked and that there was a lack of adhesion to the concrete as shown in the photographs in Figures A-16 and A-17. In addition, both of the drywell cover gaskets were uneven and not flat enough to seal. The cover gasket for Drywell 3 is shown in Figure A-18. The annulus around each liner showed quite a bit. of sand and small concrete chunks as shown in the photograph in Figure A-19 for Drywell 3. Both annuli also showed evidence of water having been present. 
To allow handling of the canister assemblies, the drywell liner thermocouples had to be removed. Problems were experienced in removing the Drywell 5 thermocouples and four thermocouples were broken off. Those thermocouple portions removed showed sheath damage in the form of cracking caused by some type of corrosion. After the canisters were removed, a visual inspection of the drywells showed several inches of water at the bottom of both liners. Both liners also had surface rust and evidence of water having run down the liner lower section. It has been postulated that the water entered the drywell annulus from under the cover gasket or was driven up through the grout/concrete pad annular gap by the drywell heat source; that once inside the annulus, the water could condense on the drywell cover and drip onto the shield plug; and that the water could run down the shield plug/liner gap and into the liner/canister annulus.

The overall effects of the water in Drywells 3 and 5 have not been completely evaluated. However, based on the thermal data results from the two isolated drywells and the amount of water present, water should have had little effect on the drywell and soil temperatures. Water vapor in the annulus between the canister and liner would be expected to increase the heat transfer between canister and liner which may cause the canister temperatures to be slightly lower than they would have been if the drywells were dry. Since the majority of the resistance to heat flow from the fuel assembly to the surrounding atmosphere is due to the low thermal conductivity of the soil around the drywell, the effect of water vapor inside the drywell should be minor. Water in the liner thermocouple tubes could have affected the temperature readings and could have caused the failure of thermocouple 828. Examining the overall temperature versus time curves for both sets of drywell liner thermocouples shows that none of the liner temperature readings exceeded $203^{\circ} \mathrm{F}$, which is below the boiling point of water at E-MAD. In addition, the liner temperature transient curves do not show any unexpected changes which could have been caused by water in the liner tubes. Therefore, the water present in the two isolated drywells was not expected to have influenced the overall drywell and soil temperature data presented in this report. 
A relatively simple design solution to prevent water from getting into drywell liners and liner thermocouple tubes during future drywell testing has been proposed. The engineered "fix" includes a sealing cover to be placed at the top of each liner and some waterproof sealing compound to be installed at the top of the liner thermocouple tubes. These two items would prevent water which gets into the drywell concrete pad annulus from entering the liner and/or the thermocouple tubes.

The above discussed Post-Isolated Drywe 11 Test observations illustrate the need and benefits gained from demonstration tests performed prior to any large-scale spent fuel dry storage activity. The evaluation of all of the observations should lead to a better drywell design which can be utilized in large-scale dry storage. 


\subsection{THERMAL ANALYSIS MODEL}

\subsection{ANALYSIS PURPOSE AND METHOD}

The purpose of the drywell thermal analysis is to continue developing a thermal model for the isolated drywell configuration and to demonstrate that the model can produce satisfactory predictions of soil and drywell temperatures. Once that goal is achieved, the model and/or the modeling techniques may be applied with increased confidence at E-MAD to spent fuel storage configurations such as the fueled drywells, the Surface Storage Casks, in-line drywells, and arrays of drywells.

Drywell test predictions and data analyses have been performed using the TAP-A digital computer program, Reference 6. TAP-A was developed at AESD and has been used extensively during the past ten years at that division and at the Westinghouse Advanced Reactors Division. It is a finite difference program which calculates steady-state and transient temperature distributions in a configuration of solid materials utilizing the radiation, convection, and conduction modes of heat transfer. To apply the program, a twoor three-dimensional configuration is divided into elements called nodes. The nodes, which are connected to each other by heat transfer links having lengths and cross-sectional areas, can have time and temperature dependent thermal properties (density, heat capacity, and conductivity) as well as time dependent heat generation rates. Outer surfaces are assigned time dependent temperatures or convective heat transfer coefficients that may also vary with time or with a surface-toambient temperature differential.

\subsection{MODEL DESCRIPTION}

\subsubsection{MODEL SIZE ANO BOUNDARY CONDITIONS}

The TAP-A nodal model applied to both Drywell 3 and Drywell 5 is depicted in Figures 28 and 29, and the nodes representing each test component are identified in Table 3. The model is two-dimensional in the $r$ and $z$ directions 


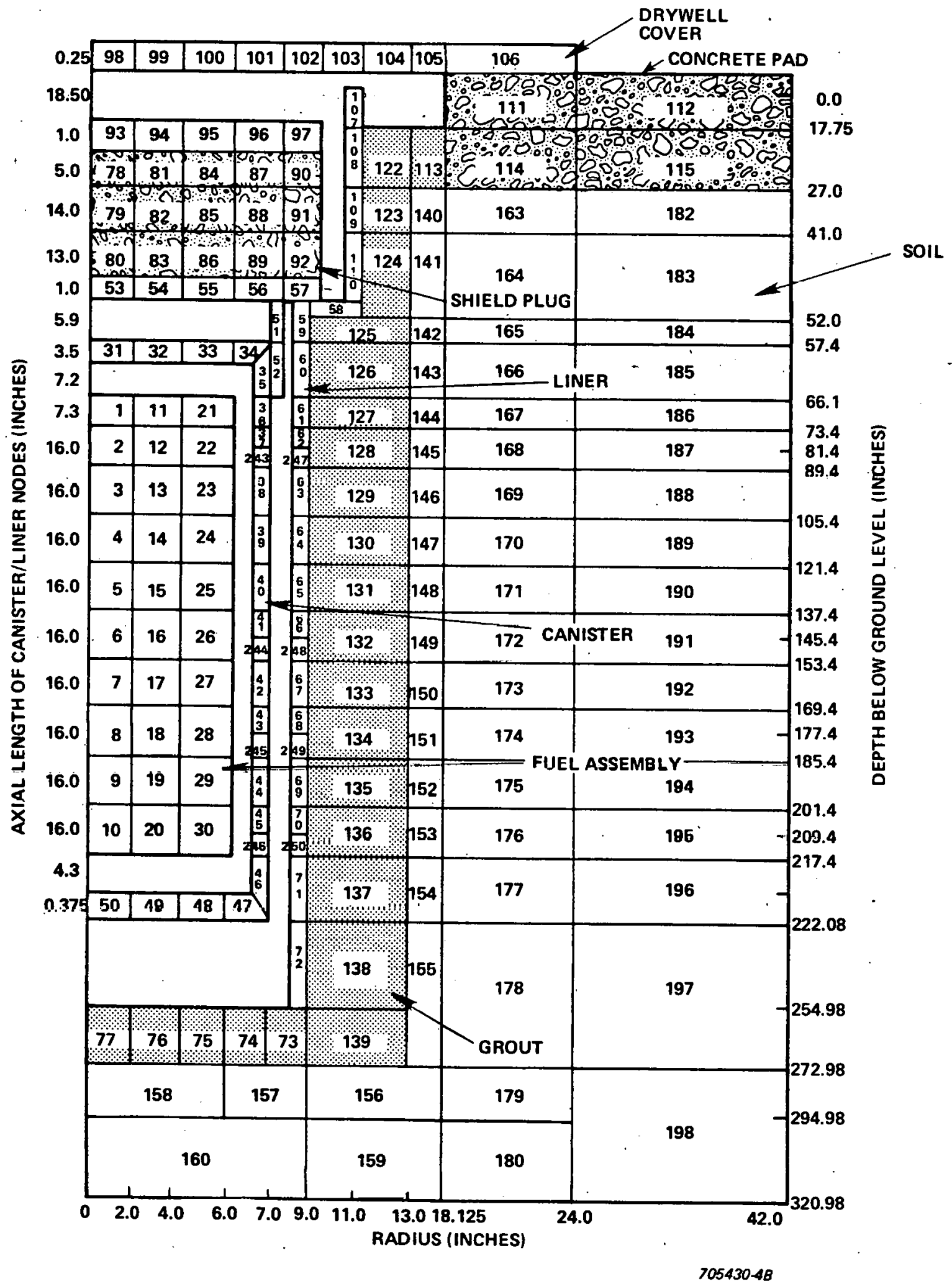

Figure 28. Near-Field Isolated Drywell Thermal Model 


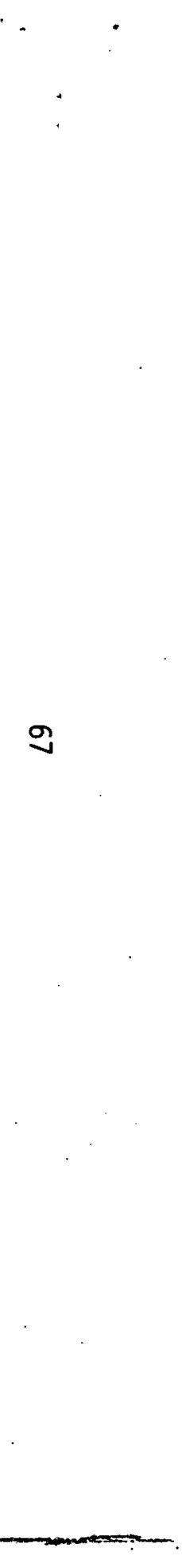

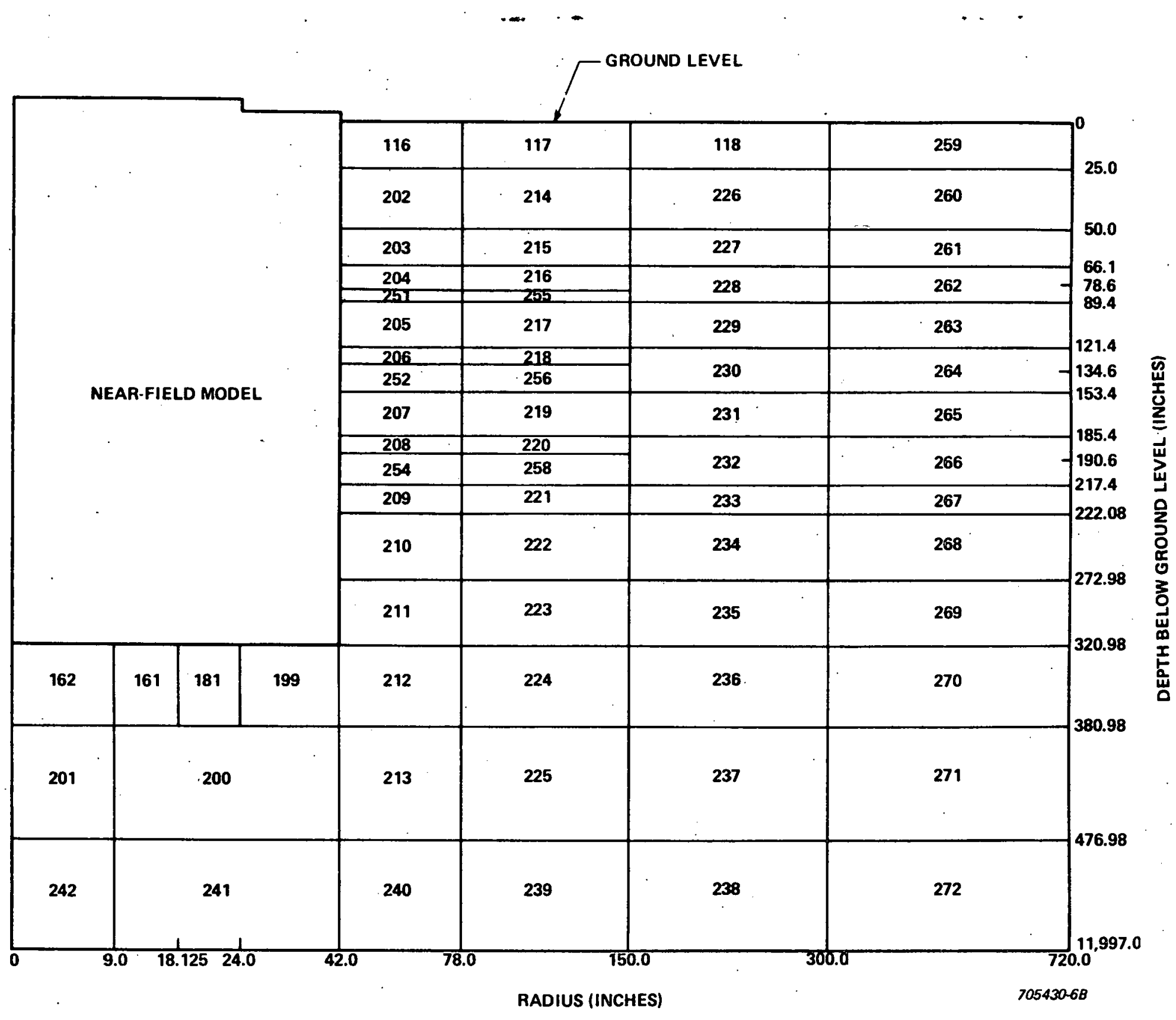

Figure 29. Far-Field Isolated Drywe11 Thermal Model 
TABLE 3

TAP-A MODEL NODE DESCRIPTION

Nodes

$1-30$

$37-50$

$57-52$

$53-57$

$58-72$

$73-77$

$78-92$

93-97

$98-106$

$107-110$

$111-112$

113

$114-115$

$116-118$

$122-139$

$140-242$

$243-246$

$247-250$

$257-272$
Test Components

Fuel Assembly.

Canister

Shield Plug Skirt

Shield Plug Bottom Plate.

Liner Lower Section

Grout at Bottom of Liner

Concrete in Shield Plug

Shield Plug Top Plate

Drywell Cover Plate

Liner Upper Section

Concrete Par

Grout

Concrete Pad

Soit

Grout Between Liner and Soil

Soil

Canister

Liner Lower Section

Soil 
(radius and depth, respectively) with no variations circumferentially. With several minor exceptions, it is identical to the Soil Temperature Test thermal model described in Reference 2. The exceptions pertain to the depth of the top of the shield plug/ canister assembly relative to the ground level ( 18.5 inches below ground level in Drywell 3 and Drywell 5 versus 2.5 inches above ground level in the Soil Temperature Test) and to the slight rearrangement of nodes to calculate temperatures at drywell thermocouple locations. The rearrangement resulted in several nodes being eliminated which explains the reduction in node number from 289 for the Soil Temperature Test to 272.

Drywells 3 and 5 were treated as being isolated. This assumption is based upon Soil Temperature Test results where ambient soil temperatures were found to exist at all radii beyond $20 \mathrm{feet}$, even while operating at $2 \mathrm{~kW}$. Therefore, Drywells 3 and 5 , separated by 50 feet with spent fuel decay heat levels at approximately $1.0 \mathrm{~kW}$ or less, were expected to have no thermal influence on each other. This assumption is further verified by the similarity in soil temperature data from Instrumentation Wells $E$ and $H$ for Orywell 3 and from Instrumentation Wells $A$ and $D$ for Drywell 5 (see Figure 15). The drywell thermal model extends to a radius of $60 \mathrm{feet}$, which is given an adiabatic boundary condition. The assignment of the model radius is arbitrary and it could be given any value greater than the radius at which the radial temperature gradients are expected to be zero (20 feet based on Soil Temperature Test results). The model lower boundary is located at a depth of 1000 feet which approximately corresponds to the E-MAD water table depth. A constant $70^{\circ} \mathrm{F}$ boundary condition is applied at that boundary simulating the water table's constant temperature heat source and sink effect.

\subsubsection{HEAT TRANSFER MECHANISMS}

Fuel Assembly/Canister Model

Heat transfer from the fuel assembly (nodes 1 to 30 ) to the canister occurs by conduction, convection, and radiation but was. modeled in this analysis only by conduction. Since TAP-A has no mass flow capability, natural circulation 
within the canister, as well as convection heat transfer effects, cannot be calculated. However, since the main objective of the analysis was the prediction of temperatures from the canister outward, this can be accomplished with a simplified fuel/ canister model. The model calculations applied an effective thermal conductivity to the fuel zone that approximates all three heat transfer modes. This effective conductivity versus temperature was calculated so that it produces reasonable fuel assembly temperatures in the $300^{\circ} \mathrm{F}$ to $800^{\circ} \mathrm{F}$ range. This was necessary for proper drywell transient response. The fuel assembly heat capacity is modeled accurately to also produce a proper transient response. The model was supplied with an accurate estimate of the fuel assembly mass of 1450 pounds and a specific heat capacity of 0.066 Btu/1b- ${ }^{\circ} \mathrm{F}$ which represented, in proper proportions, the heat capacities of the Zircaloy clad, the $\mathrm{UO}_{2}$ fuel and the stainless steel nozzle plates.

\section{Air Filled Spaces}

Heat transfer across air filled spaces (between the canister and liner, the canister lid and shield plug, the shield plug and cover plate, and the shield plug and upper liner) are modeled considering radiation and a combination of conduction and convection. Radiation is included in the analys is by supplying shape factors that depend upon emissivities and areas of the radiating surfaces. For convection and conduction, correlations are available that allow both heat transfer modes to be handled in a single calculation. Between the canister and liner side walls, for example, convection and conduction were simulated using the "effective conductivity" method described in Reference 7 (pages 330, 331). For an annulus thickness of 1.625 inches and a temperature differential of $50^{\circ} \mathrm{F}$, the effective thermal conductivity is 1.5 to 3 times larger than the conductivity of air for temperatures between $200^{\circ} \mathrm{F}$ and $600^{\circ} \mathrm{F}$. For narrow annuli, such as that between the shield plug and upper liner, convection is suppressed, conduction dominates, and the correlation reduces to air's thermal conductivity. Convection effects were also assumed to be negligible in the region below the canister assuming air at that location would tend to stratify. 
Convection should be more significant above the canister between the canister lid and shield plug. A correlation presented in Reference 8 (page 182, Eq. 7-9d) predicts an effective thermal conductivity across the 5.9 inch gap of approximately $0.2 \mathrm{Btu} / \mathrm{hr}-\mathrm{ft}-{ }^{\circ} \mathrm{F}$. This assumes a temperature differential of $60^{\circ} \mathrm{F}$, based on Soil Temperature Test data taken during $1.0 \mathrm{~kW}$ operation and is 12 times larger than air's thermal conductivity at $200^{\circ} \mathrm{F}$. The difference is due to free convection.

Convection was ignored between the shield plug and drywell cover plate. Those effects are probably appreciable during the nighttime hours and winter months. However, they were neglected since the result of averaging them with time would be very uncertain and, since heat transfer rates through the shield plug are small compared to the total heat generation rate, their omission will have a very small effect on the analysis. The same is probably true for any of the canister end effect calculations and, therefore, most attention was given to the canister/liner side wall model.

\section{Ground-to-Ambient lleat Transfer}

The Soil-Temperature Test analysis, reported in Reference 2, considered solar effects at ground level as well as convection to and from the ambient air. Further work has confirmed, however, that the ground level model can be simplified, with satisfactory results, by equating air and surface temperatures and ignoring the solar effects. This approach has been applied throughout the drywell analyses; the air temperatures used are monthly temperature averages taken from E-MAD site weather data and are provided in Table 4. This approach is confirmed in that the model predicts seasonal soil temperature variations with good accuracy and, at any particular time, Reference well temperatures are predicted to within $5^{\circ} \mathrm{F}$ of the measured values. The ground-to-ambient heat transfer model's acceptability is apparent in Section 7.0 where transient soil temperatures at various depths and radii are compared with predictions with favorable results. 
TABLE 4

E-MAD SITE OUTDOOR AIR TEMPERATURES - MONTHLY AVERAGES

Month

January

February.

March

Apri1

May

June

July

August

September

Uctober

November

December
Temperature $\left({ }^{\circ} \mathrm{F}\right)$

36

50

55

60

75

82

90

88

80

75

50

35 


\subsubsection{MATERIAL PROPERTIES}

Thermal properties used in the analys is of Drywells 3 and 5 are identified in Table 5 and are identical to those applied in the Soil Temperature Test analysis. The concrete and steel properties are from handbook and textbook sources, while the density and thermal conductivity data for grout and soil were obtained during laboratory tests performed by Holmes and Narver, Inc. The grout conductivity data are plotted in Figure 30. As discussed in Reference 2, the development of a soil thermal conductivity model for use in the drywell analyses was based upon the Holmes and Narver data, but the data were adjusted, mainly at temperatures below $200^{\circ} \mathrm{F}$ to include additional moisture effects. The resulting conductivity model is shown in Figure 31 . The soil conductivity model exhibits a strong temperature dependency due to drying that occurs when temperatures exceed $200^{\circ} \mathrm{F}$ (the approximate boiling point of water at E-MAD). For Drywells 3 and 5, however, the heat generation rates are low such that predicted soil temperatures were never greater than $160^{\circ} \mathrm{F}$. Therefore, throughout the drywell analysis, the soil thermal conductivity value was set at 0.9 $\mathrm{Btu} / \mathrm{hr}-\mathrm{ft}-{ }^{\circ} \mathrm{F}$. In sandy soils, this corresponds to a moisture content of approximately 5 percent, which is the moisture level detected in E-MAD soil samples during preparations for the Soil Temperature Test (Reference 2).

With this conductivity value, the thermal model predicted liner and soil temperatures accurately during the first four months of drywell testing. Thereafter, however, the model underpredicted the liner temperatures by increasing amounts until, at the end of the test period, the discrepancy was as high as $30^{\circ} \mathrm{F}$. This discrepancy was assumed to have been caused by a drying out of the soil around the drywell due to the heat source. The drying effect would decrease the thermal conductivity of the soil and consequently cause the liner and soil temperatures to be higher. To improve the liner and canister predictions, a soil conductivity versus time relationship was derived from the decay heat curve, Figure 12, and measured values of midplane liner and soil temperatures at the 5 foot radius. The resulting relationship is plotted in Figure 32 and was used to obtain the temperature predictions presented herein. It is 
TABLE 5

DRYWELL MATERIAL THERMAL PROPERTIES

\begin{tabular}{|c|c|c|c|c|c|}
\hline Material & Drywe 11 Conponent & $\begin{array}{l}\text { Density } \\
\mathrm{e}\left(\mathrm{lb} / \mathrm{ft}^{3}\right)\end{array}$ & $\begin{array}{l}\text { Heat Capacity } \\
\underline{C}_{p}\left(\text { Btu } / 1 b-{ }^{\circ} F\right)\end{array}$ & $\begin{array}{c}\text { Thermal } \\
\text { Conductivity } \\
\left.\text { K(Btu/hr-ft- }{ }^{\circ} \mathrm{F}\right)\end{array}$ & Source \\
\hline Concrete & $\begin{array}{l}\text { Shield pluy, ground } \\
\text { level pad }\end{array}$ & .142 .0 & 0.2 & 1.05 & Ref. 9, pp. 4-9, 4-97 \\
\hline Stainless Steel & Canister & 490.0 & 0.11 & 10.0 & R:f. $10, p .533$ \\
\hline Carbon Steel & $\begin{array}{l}\text { Liner, dryivell } \\
\text { cover platz, } \\
\text { shield pluy can }\end{array}$ & 490.0 & 0.11 & 23.0 & Ref. 10, p. 533 \\
\hline Grout & Grout & 117.0 & $0.20 *$ & See Fig. 30 & \\
\hline Soil & Soil & 105.0 & $0.25 \star \star$ & See Figs. $31 \& 32$ & \\
\hline
\end{tabular}

*Value based on dry soil, dry concrete $c_{p}$ values.

**Dry soil plus 5 percent mo isture assumed. 


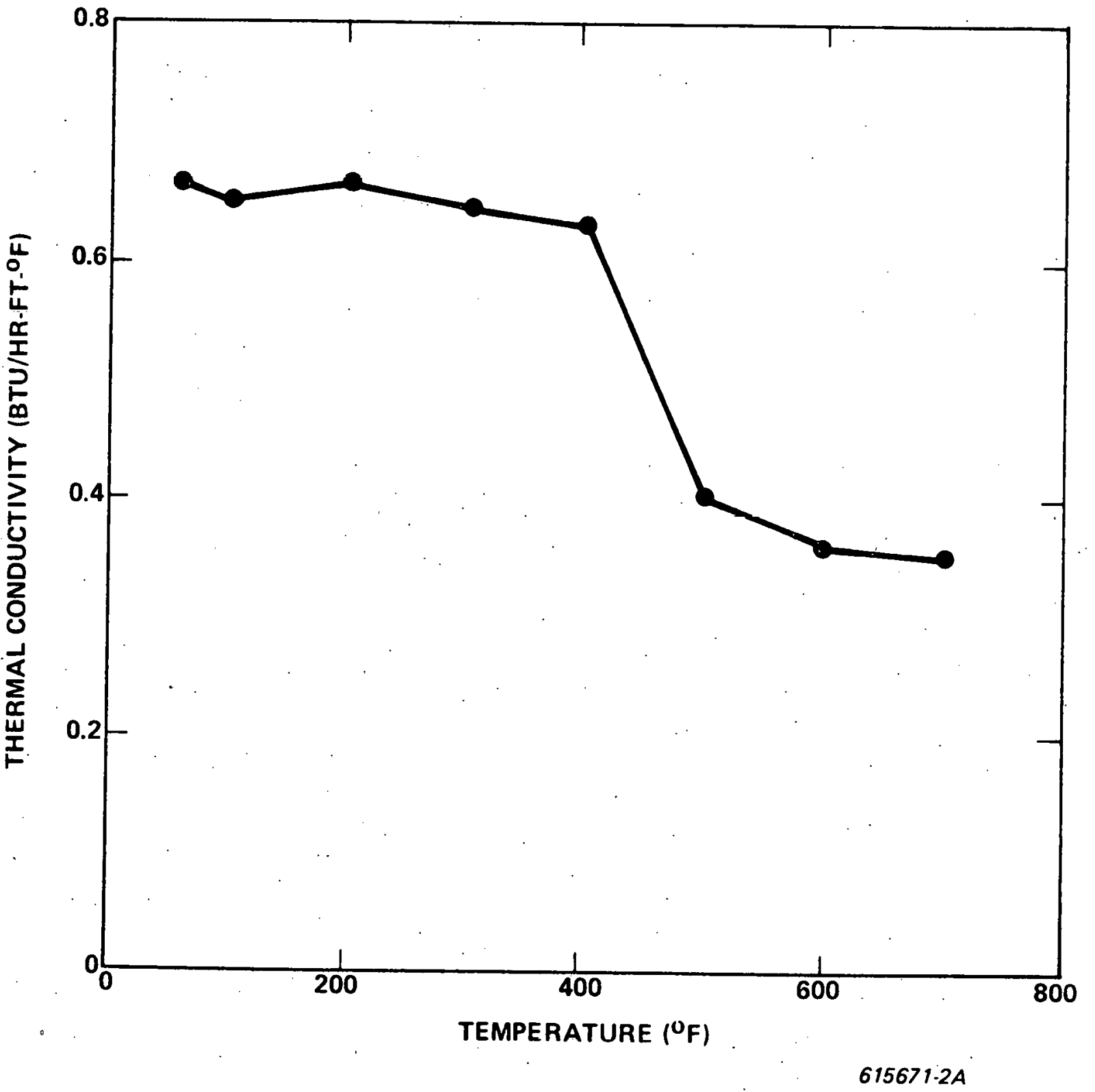

Figure 30. Laboratory Measured Grout Thermal Conductivity 


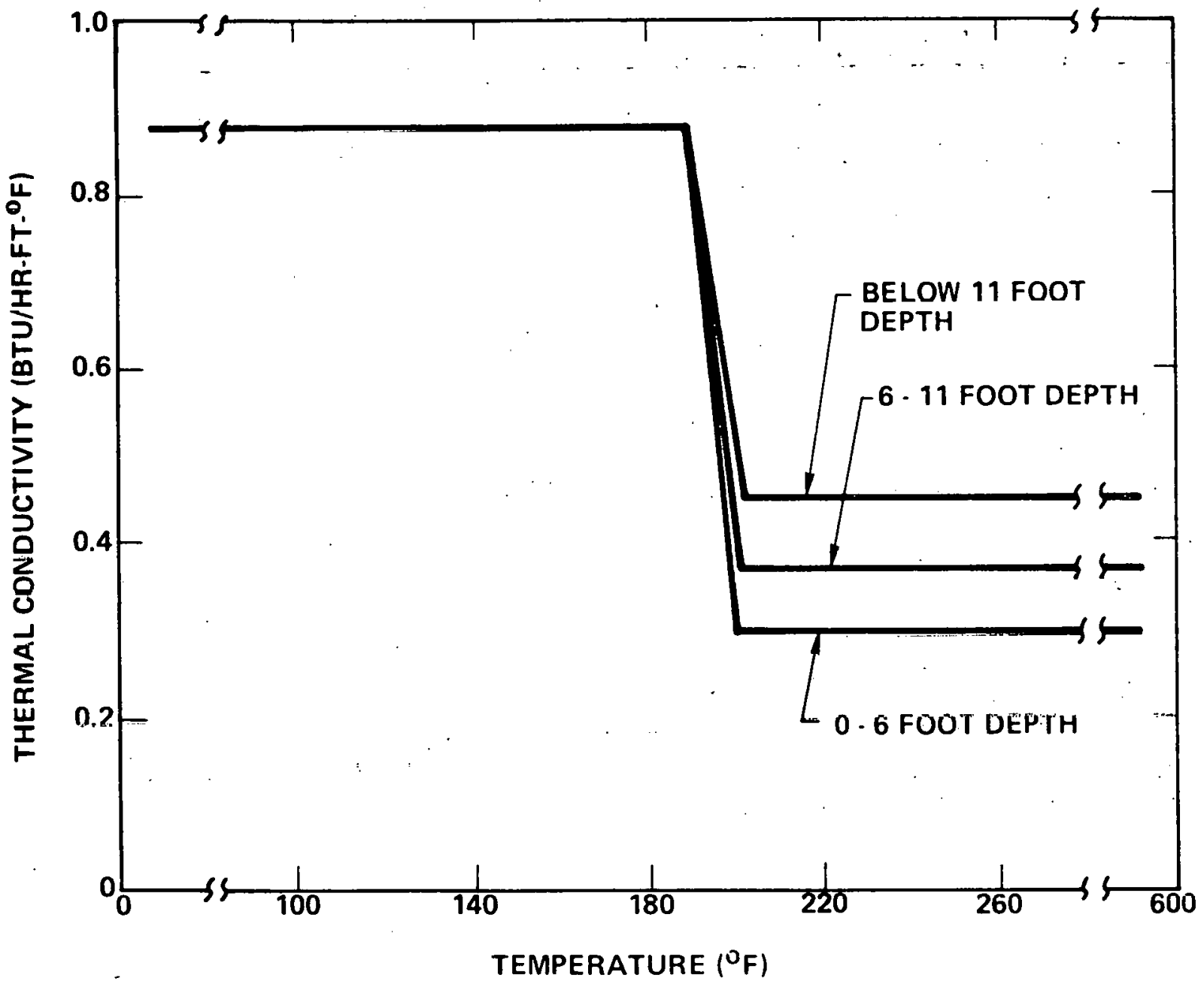

$615671-6 A$

Figure 31. E-MAD Soil Thermal Conductivity Derived

From Soil Temperature Test Data (Reference 2) 


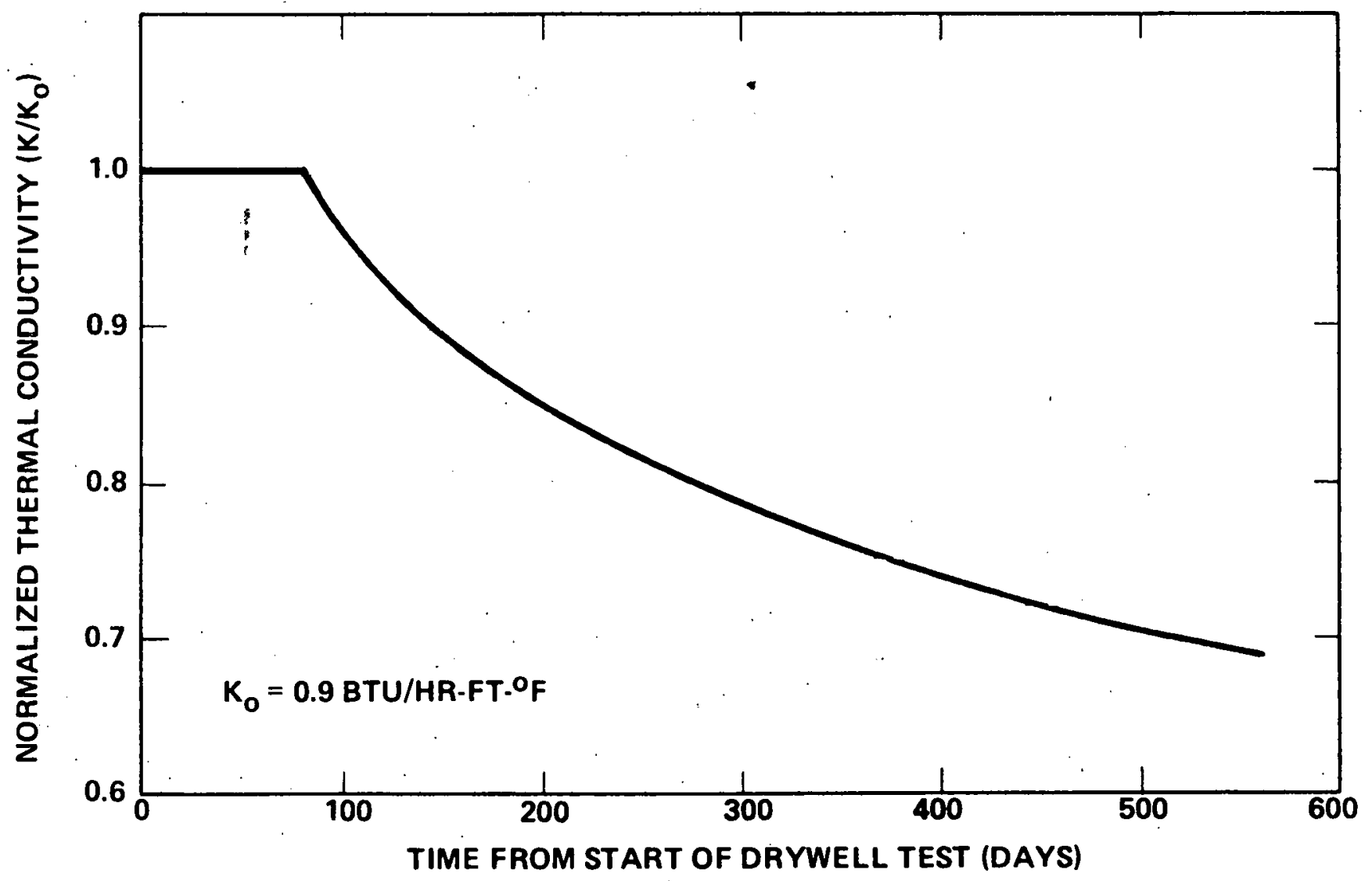

$705430-8 A$

Figure 32. Near-Field Soil Thermal Conductivity Derived

From Drywell 5 Decay Heat Levels and

Temperature Data 
noted that the time dependent conductivity curve was applied only to near-field soil (thermal model nodes 140-155, 163-178, and 182-197); all other soil nodes were assigned a constant thermal conductivity of $0.9 \mathrm{Btu} / \mathrm{hr}-\mathrm{ft}-{ }^{\circ} \mathrm{F}$ throughout the calculations.

\subsubsection{FUEL ASSEMBLY HEAT GENERATION RATE}

The thermal analyses applied the transient spent fuel decay heat curve shown in Figure 12. The curve is the result of calculations using the ORIGEN code (Reference 11) that apply to the fuel assemblies installed in Drywells 3 and 5 . At emplacement, the decay heat level for the Drywell 5 fuel assembly was about $1.09 \mathrm{~kW}$ (January 12, 1979) and about $1.03 \mathrm{~kW}$ (Janaury 25, 1979) for the Drywell 3 fuel assembly. The drywell analysis discussed herein assumed all heat was produced in the fuel zone (nodes 1 to 30 ). The small effect of gamma heating in the system steel structures was neglected. The volumetric heat generation rate was distributed uniformly over the entire fuel zone. This resulted in a cosine shaped heat flux distribution at the canister wall that is similar to that deduced from canister and liner temperature data. 


\subsection{THERMAL ANALYSIS RESULTS}

\subsection{MODEL EVALUATION CRITERIA}

With proper input, the drywell thermal model should produce accurate temperature predictions for the canister, liner, and near-field soil zone. Accurate canister temperatures are important as input to independent fuel assembly studies (Fuel Temperature Test, etc.) while accurate soil temperatures are important for drywell array and thermal interaction analyses. The most important model evaluation criteria is that it must correctly predict temperature trends and relationships over a range of power levels and as the seasons vary. Satisfying this third criteria will demonstrate that the thermal model correctly simulates the appropriate heat transfer mechanisms and maintains the proper relationships between these mechanisms as system forcing functions and boundary conditions change. As long as the model satisfies this criteria, small differences between predicted and measured temperatures should not be of concern. In most cases, the differences can be recognized and explained based upon inaccuracies in model input, actual test configuration uncertainties and/or heat transfer mechanism uncertainties.

\subsection{MODEL/DATA COMPARISONS}

In the following sections, thermal model temperature predictions are compared with test data from Drywel1 5. Predictions for Drywell 3 are not discussed since they, as well as the Drywell 3 test data, are very similar in trend and magnitude to the Drywell 5 data and calculations.

\subsubsection{CANISTER AND LINER AXIAL TEMPERATURE PROFILES}

Predicted temperature profiles for the Drywe 115 canister and liner are compared with test data in Figure 33. The curves apply to August, 1979, when the peak canister temperatures occurred. Generally, the test data and predictions are in good agreement. This is an indication that the heat transfer model for the canister/liner region is satisfactory, and also that for a helium-filled 


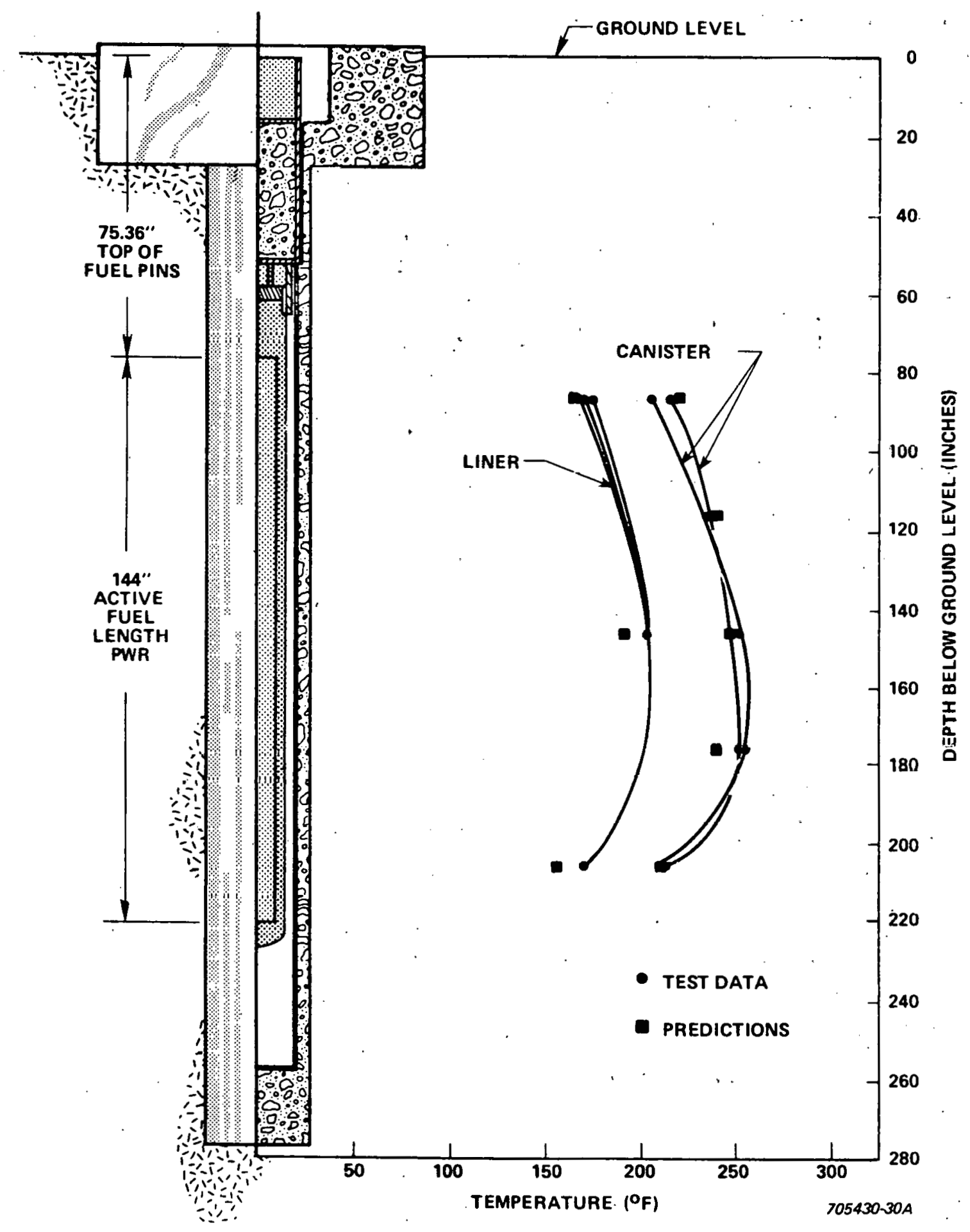

Figure 33. Drywel1 5 Test Data and Predictions Comparison of Canister and Liner Axial Temperature Profiles 
canister, the fuel assembly can be represented as a uniform heat generating zone. With an air-filled canister, as discussed in Reference 2, it was necessary to skew the heat generation towards the top of the canister to account for the heat redistributing effects of natural circulation within the canister and its impact on the predictions of canister, liner, and soil temperature at elevations near the canister ends. Thus, as noted in Reference 2, analyses of a " illed canisters should include a more detailed model that includes natural circulation. With helium, circulation effects are apparently not so significant, as evidenced by the results of the present analysis, and the simpler canister model with no circulation is suitable.

\subsubsection{TRANSIENT CANISTER, LINER, AND SOIL TEMPERATURES}

Measured and predicted drywell temperatures are plotted as functions of time in Figures 34 to 38 . Each figure applies to a specific instrument elevation and includes all test data recorded at that elevation. Comparing predictions with all available data is necessary when, as in several canister and liner cases, the data indicate some circumferential temperature variations. As noted earlier, the variations can be explained by instrument inaccuracies and errors in thermocouple placement; they are not taken necessarily as evidence that canister and liner temperatures actually vary with angular position.

In general, the agreement between the predicted and measured temperatures is satisfactory. In particular, the soil temperature predictions at the 5 and 10 foot radii.are very accurate. The correct differential is maintained between them, the amplitude of the seasonal temperature variations shows the correct depth dependency and the temperature traces at the three elevations are correctly phased relative to each other. These observations indicate the soil's thermal conductivity and thermal diffusivity at the 5 and 10 foot radii are modeled properly.

Although the thermal model tends to overpredict the canister/ liner temperature differential, the calculations displayed in Figures 34,36 , and 38 are still reasonably accurate and acceptable. Of most importance is the fact that the 


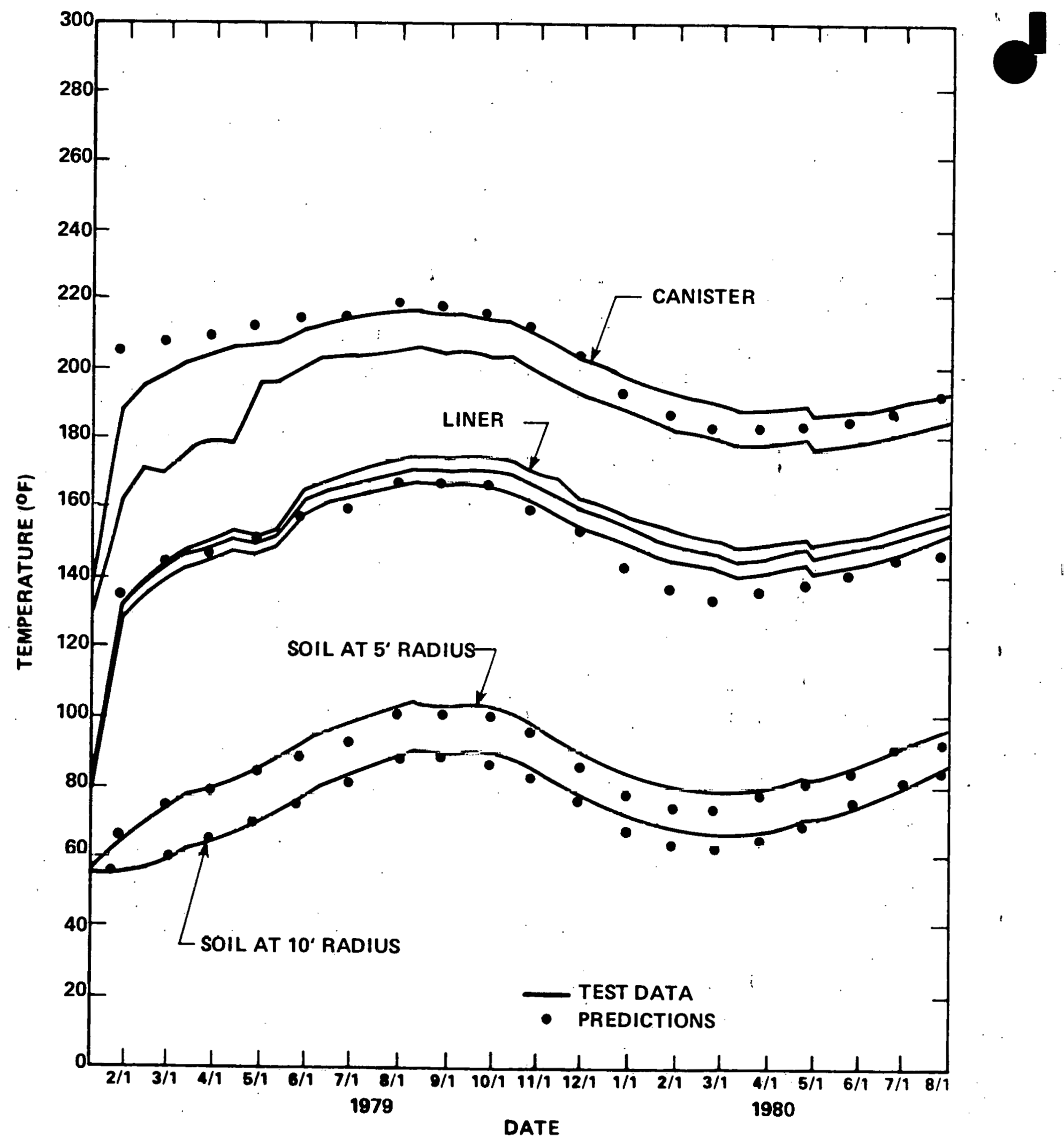

705430-29A

Figure 34. Drywell 5 Test Data and Predictions Comparison at About 85 Inches Below Ground Level 


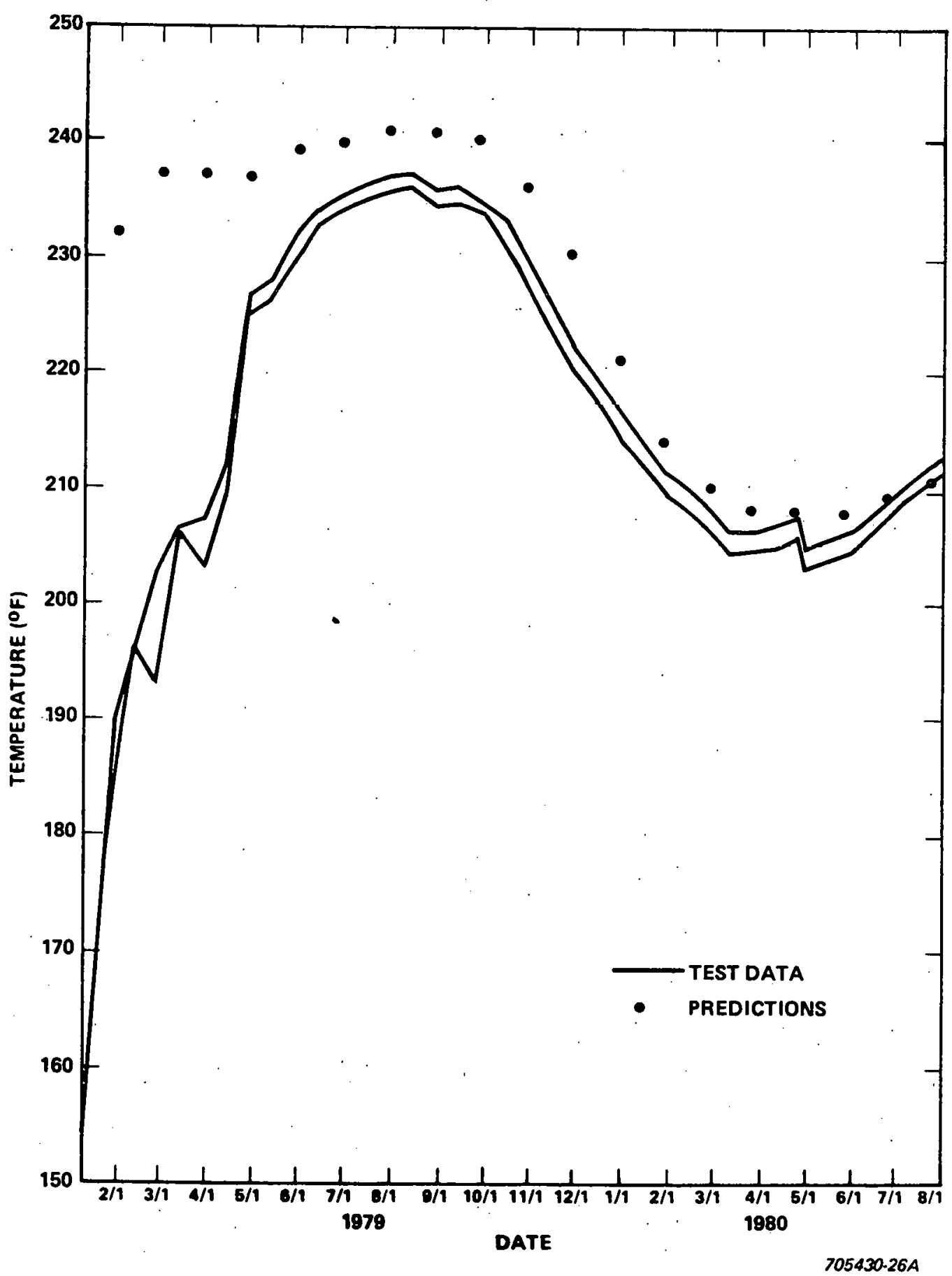

Figure 35. Drywell 5 Canister Test Data and Predictions: Comparison at 116 Inches Below Ground Leve 1 


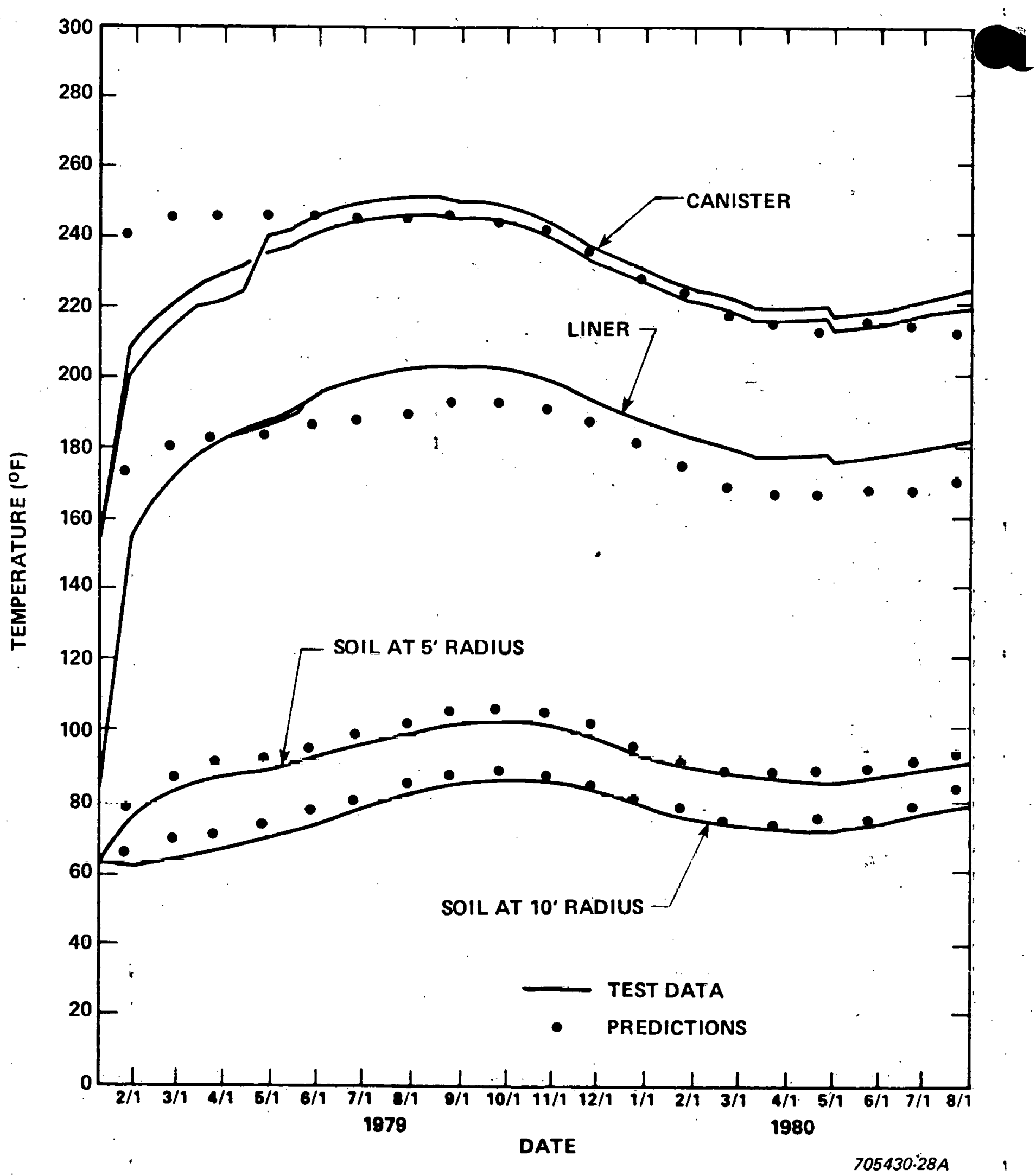

Figure 36. Drywe11 5 Test Data and Predictions Comparison at About 145 Inches Below Ground Level 


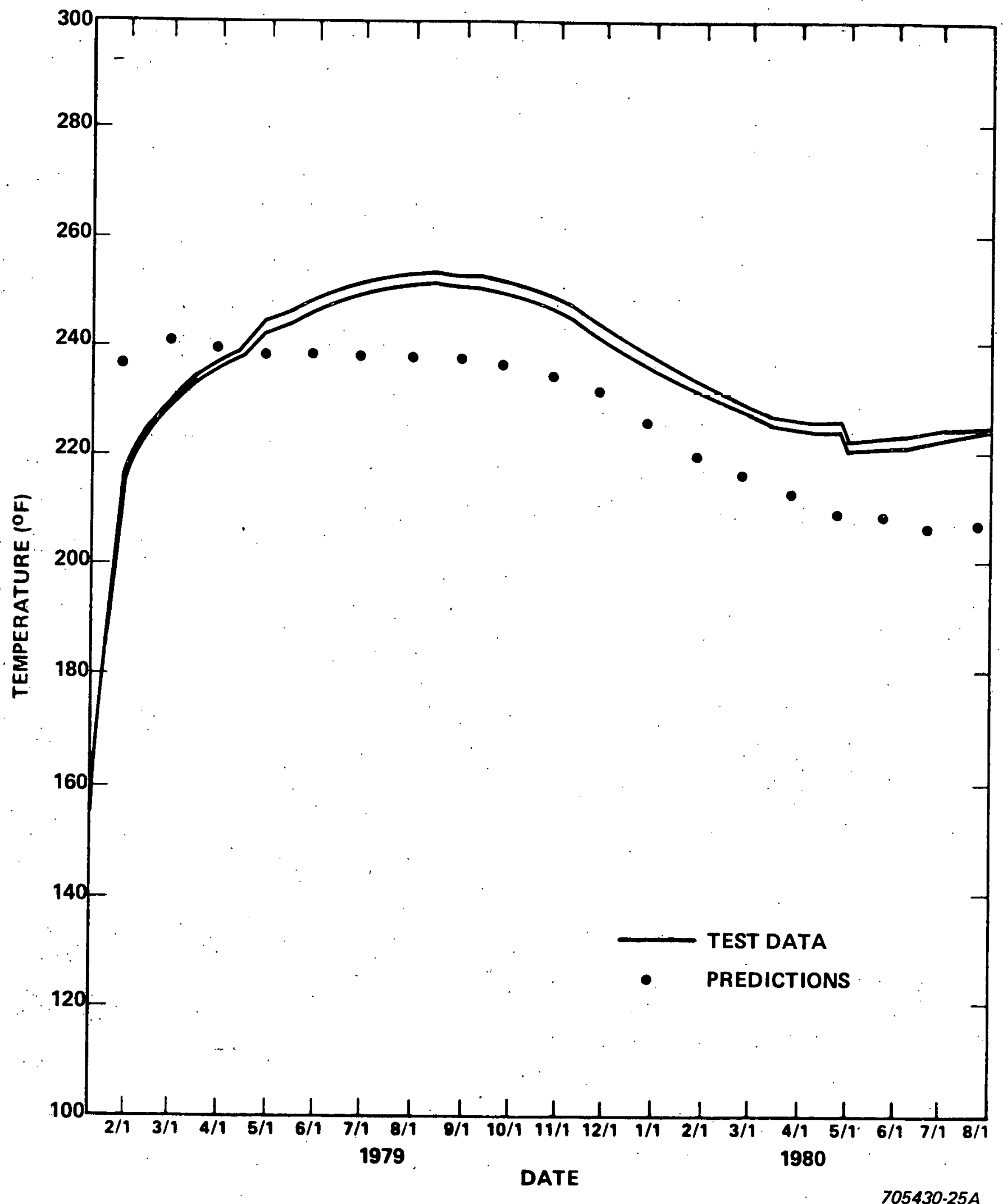

Figure 37. Drywe11 5 Canister Test Data and Predictions Comparison at 176 Inches Below Ground Level 


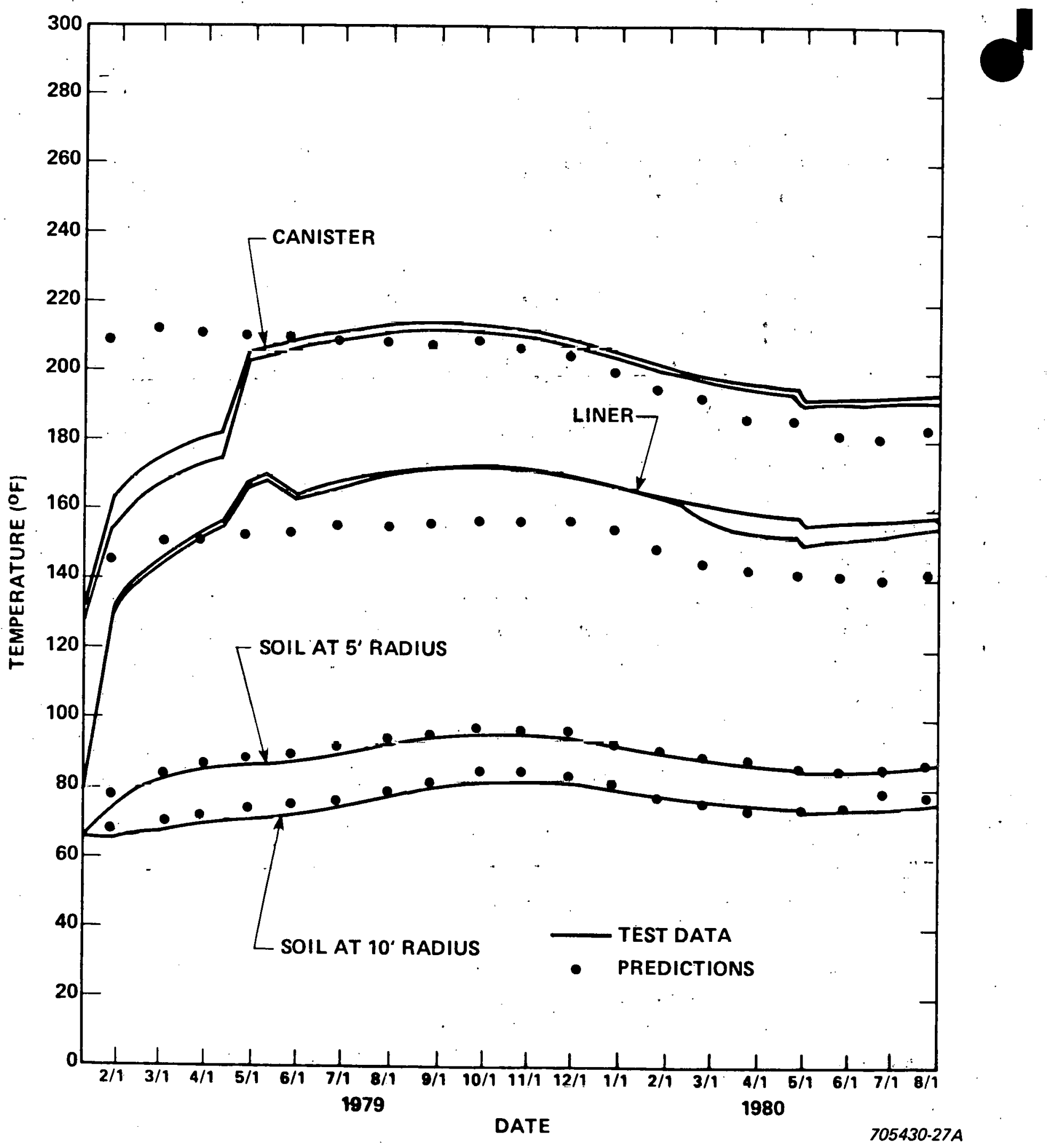

Figure 38. Drywell 5 Test Data and Predictions Comparison at About 205 Inches Below Ground Level 
model correctly predicted the tendency of the differential to remain essentially constant over most of the 19 month test period. During that time, the decay heat level decreased from about $1.1 \mathrm{~kW}$ to approximately $0.65 \mathrm{~kW}$, and the model's good performance is an indication that radiation and conduction/ convection between the canister and liner are calculated in the proper proportions. The tendency to overpredict the temperature differential is attributed to inaccuracies input to the radiation and conduction/convection models. The accuracy of the "effective conductivity" type of correlation is typically no better than about \pm 20 percent while emissivities and reflectivities of surfaces are known with less accuracy. In design analyses, such inaccuracies would be accounted for by estimating them and selecting conservative parameter values for use in the calculations.

An interesting observation in Figures 34,36 , and 38 concerns the fact that the temperature differentials between the liner and the 5 foot radius remained practically constant during most of the test period while, as noted above, the heat load was decreasing by nearly 40 percent. The most probable explanation is that soil in the near-field zone dried gradually as the test progressed. This caused, in turn, a continual reduction in the thermal conductivity of the soil which would result in higher temperature differentials while the heat transfer rate declined.

In Figures 34 to 38 , the largest discrepancies between the predicted and measured temperatures occur early in the test period when drywell temperatures were rising rapidly. Regarding the canister and liner, the predicted temperatures rise more rapidiy and tend to overshoot the measured values. This is judged to be a heat capacity prediction inaccuracy most likely caused by soil and grout moisture and the inability of the current thermal model to accurately treat moisture evaporation. The inaccuracy is not of great concern since peak temperatures and their times of occurrence are predicted fairly accurately. It is only during the initial heatup period that calculated temperatures tend to be overly' conservative. 


\subsection{REFERENCES}

1. NVy-198, "Safety Assessment Document for the Spent Fuel Handling and Packaging Program Demonstration at the Nevada Test Site," U. S. Department of Energy, December, 1978.

2. DOE/NV/00597-2, "Spent Fuel Dry Storage Technology Development: Electrically Heated Drywell Storage Test (1 kW and $2 \mathrm{kll}$ Operation)," Westinghouse Advanced Energy Systems Division, June, 1980.

3. DOE/NV/00597-4, "Spent Fuel Dry Storage Technology Development: Fuel Temperature Measurements Under Imposed Dry Storage Conditions $11 \mathrm{~kW} \mathrm{PWR} \mathrm{Spent}$ Fuel Assembly)," Westinghouse Advanced Energy Systems Division, September, 1980.

4. DOE/NV/00597-3, "Spent F!sel Dry Storage Technology Development: Thermal Evaliation of Sealed Storage Cask Containing Spent Fuel," Westinghouse Advanced Energy Systens Division, August, 1980.

5. HEDL-TME-79-68, "Data Report for the Nondestructive Examination of Turkey Point Spent Fuel Assemh1ies B02, B03, B17, B41, and B43," Hanford Engineering Development Laboratory, Apri1, 1980.

6. WANL-TME-1872, Pierce, B. L., and Stumpf, H. J., "TAP-A Program for Computing Transient or Steady-State Temperature Distributions," Westinghouse Astronuclear Laboratory (now Advanced Energy Systems Division), December, 1969.

7. Eckert, E. R., and Drake, R. M., Jr., "Heat and Mass Transfer," Second Edition, McGraw-Hill Book Co., Inc., 1959.

8. McAdams, W. H., "Heat Transmission," McGraw-Hill Book Co., Third Edition, 1954.

9. Mark's Mechanical Engineers Handbook, McGraw-Hill Book Co., 6th Edition, 1958.

10. Kreith, F., "Principles of Heat Transfer," Scranton International Textbook Co., 1958.

11. ORNL-4628, Be11, M. J., "ORIGEN - The ORNL Isotope Generation and Depletiọn Code," Dak Ridge National Laboratory, May 1973. 
APPENDIX A

\section{DRYWELL TEST HARDWARE AND INSTALLATION}

This Appendix provides additional illustrations of Drywell Test hardware and installation. Figures A-1 through A-15 show photographs taken during the construction, assembly, and installation of the Drywell Test hardware. Figures A-16 through A-19 show photographs taken during drywe 11 rearrangement activities at the conclusion of the Isolated Drywell Test. 


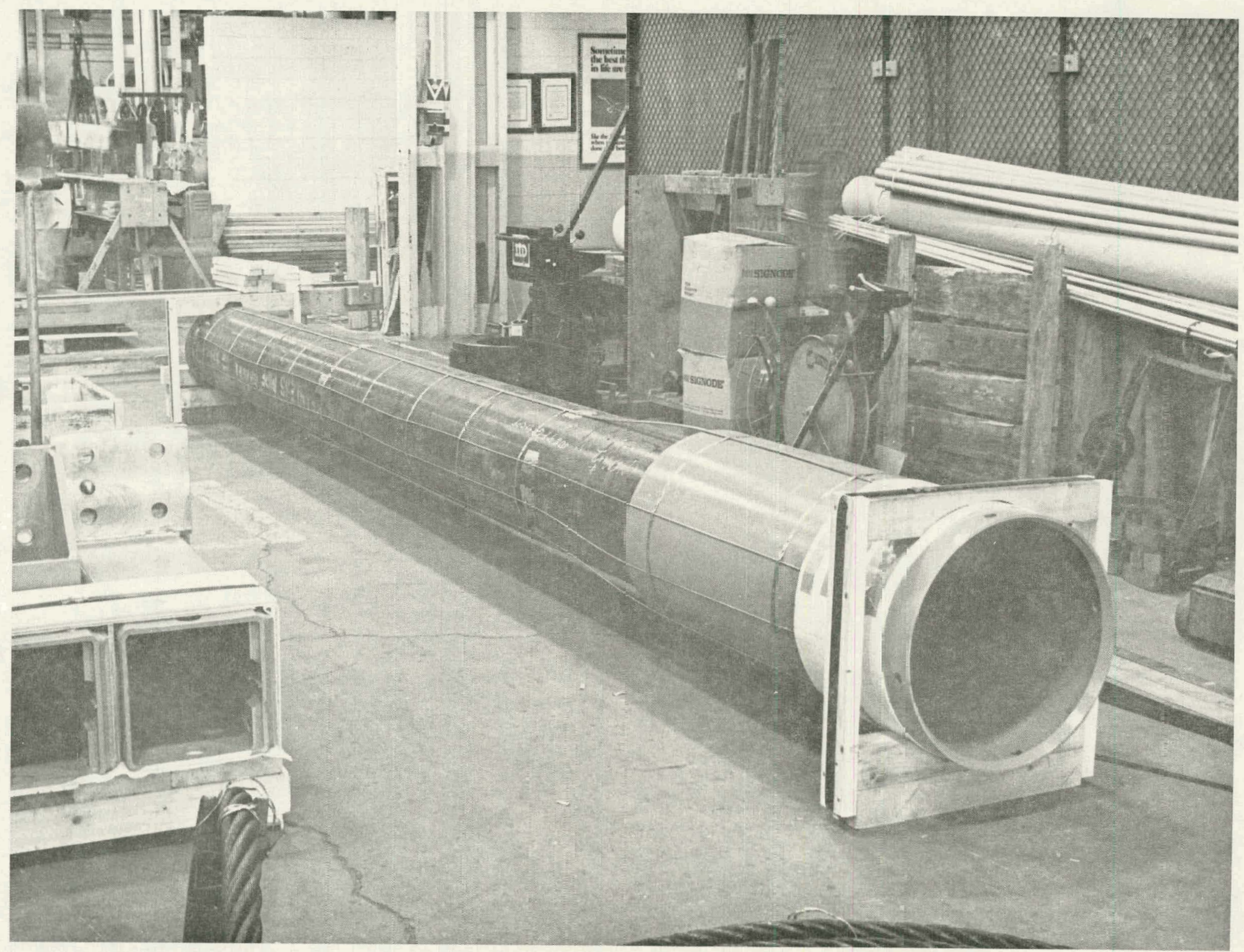

Figure A- - Drywe11 Liner Prior to Shipment 


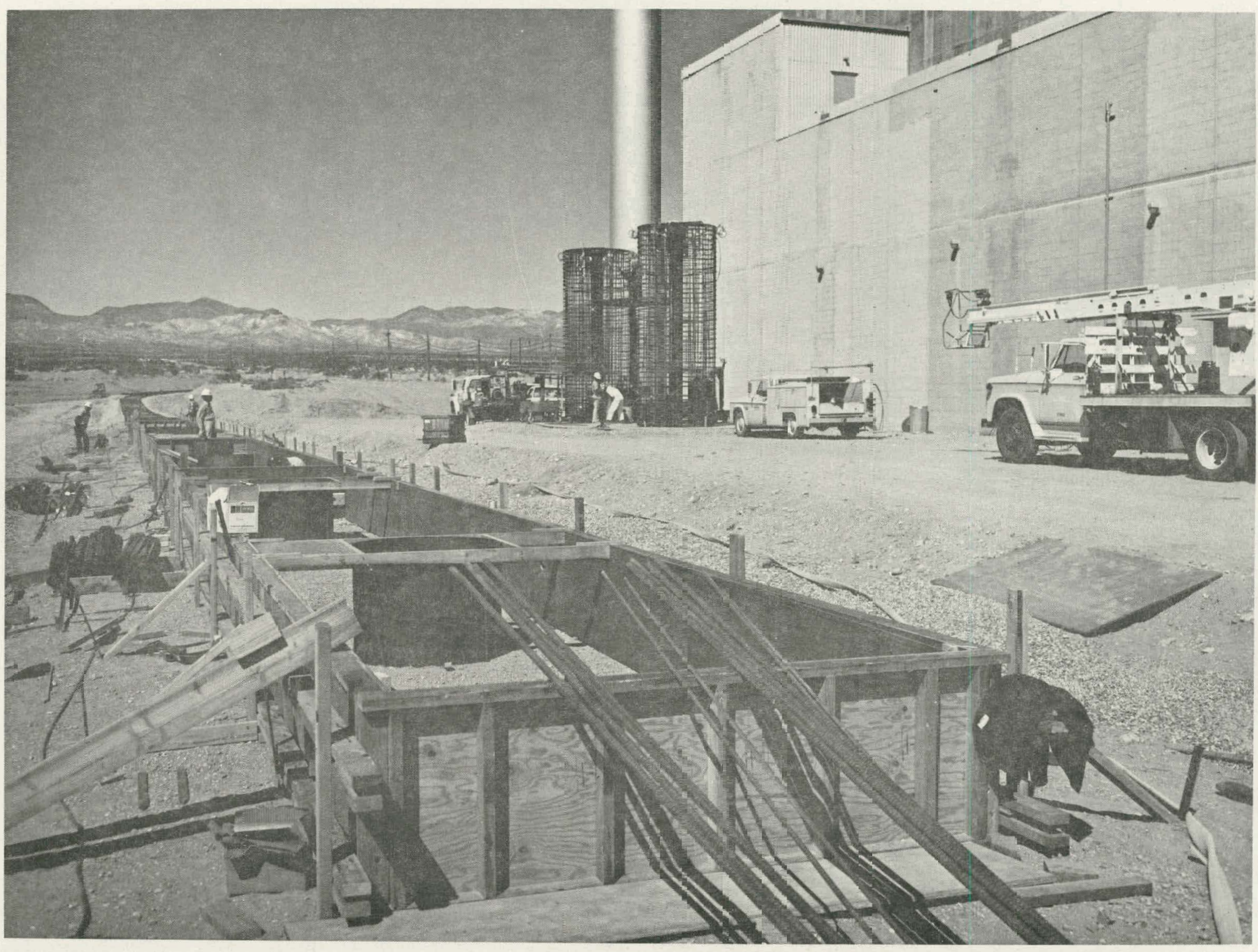

Figure A-2. Drywell Storage Aræa Construction 


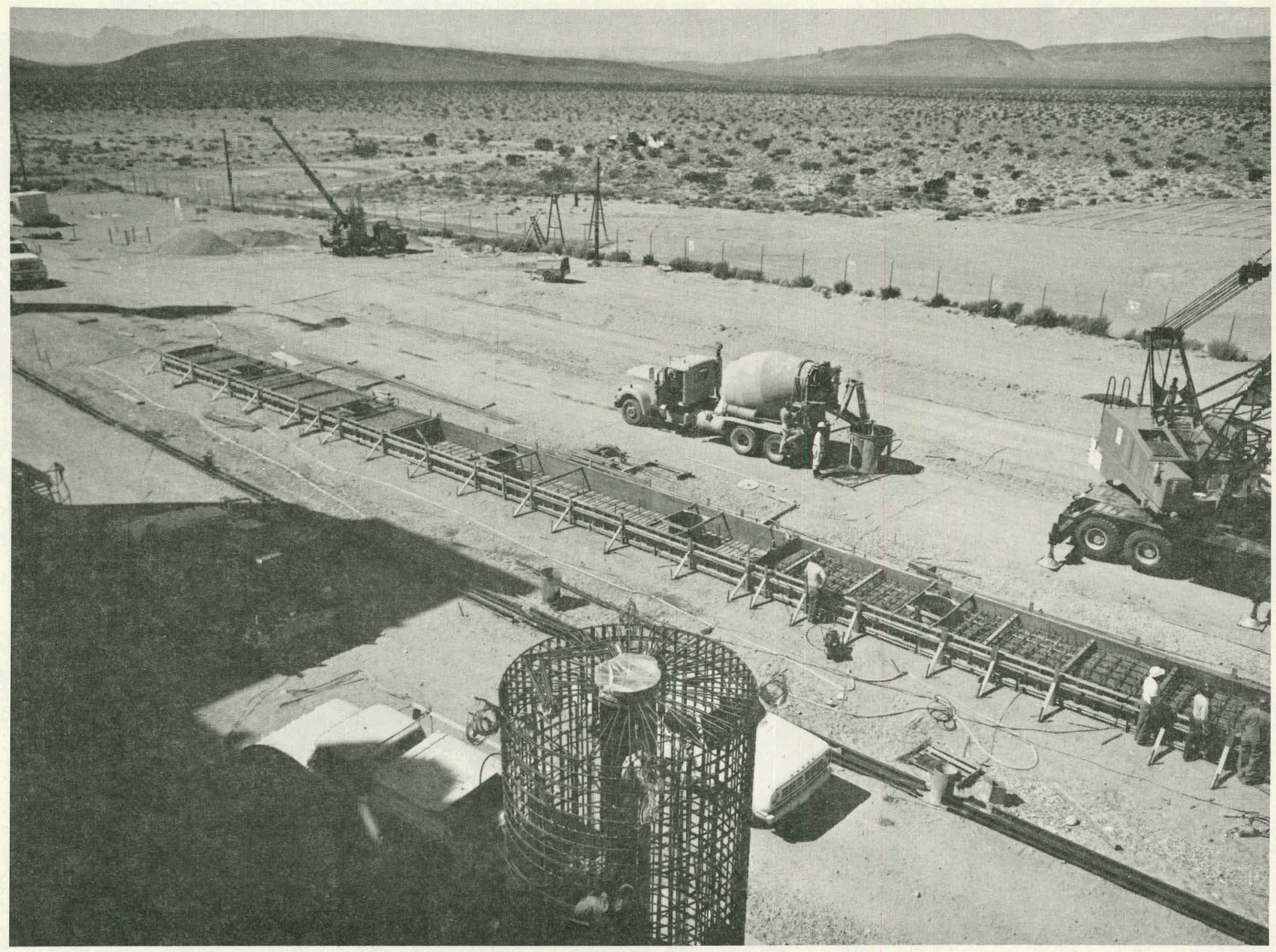

Figure A-3. Drywe11 Storage Area Construction 


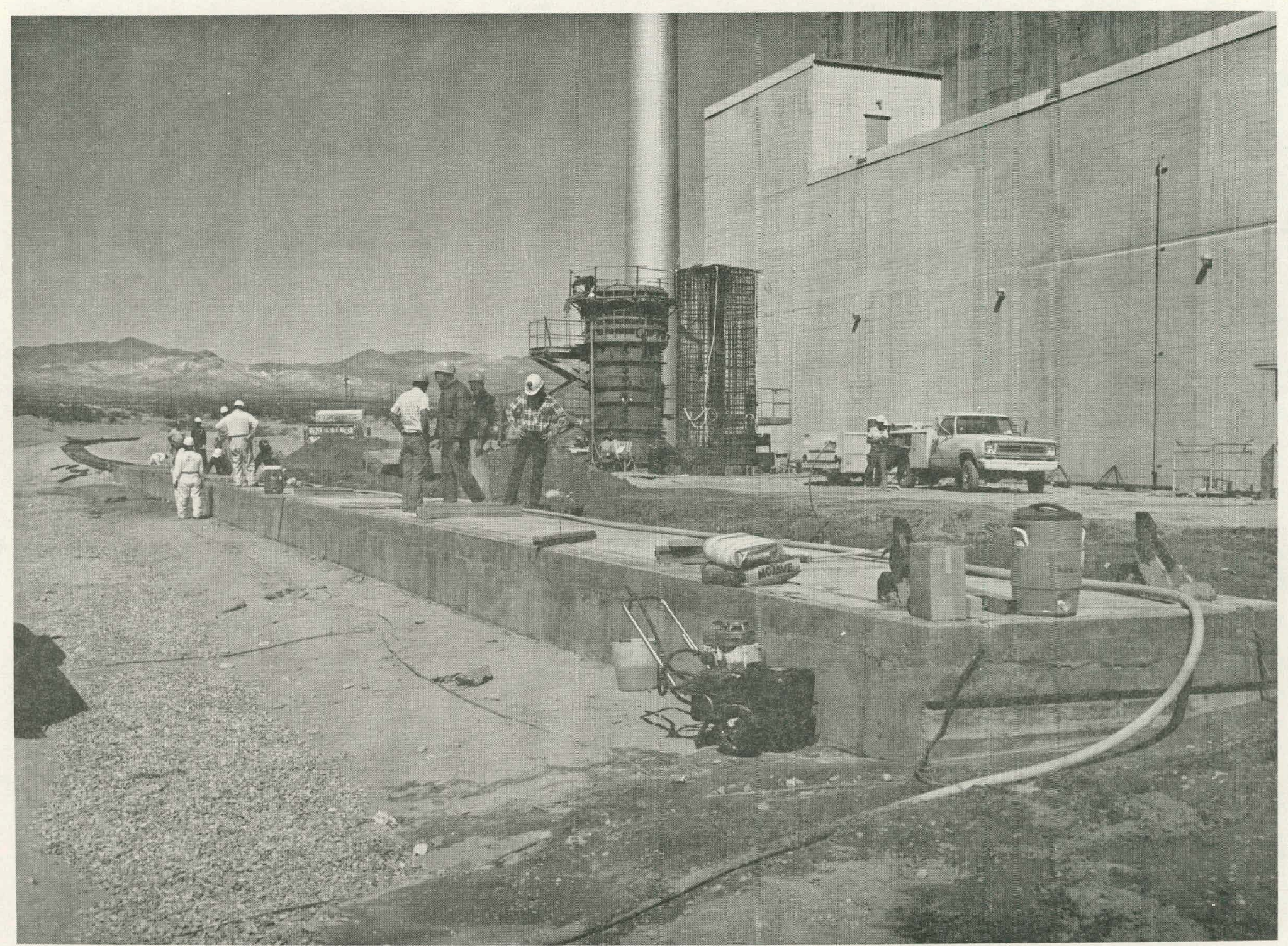

Figure A-4. Drywel1 Starage Area Construction Completed 


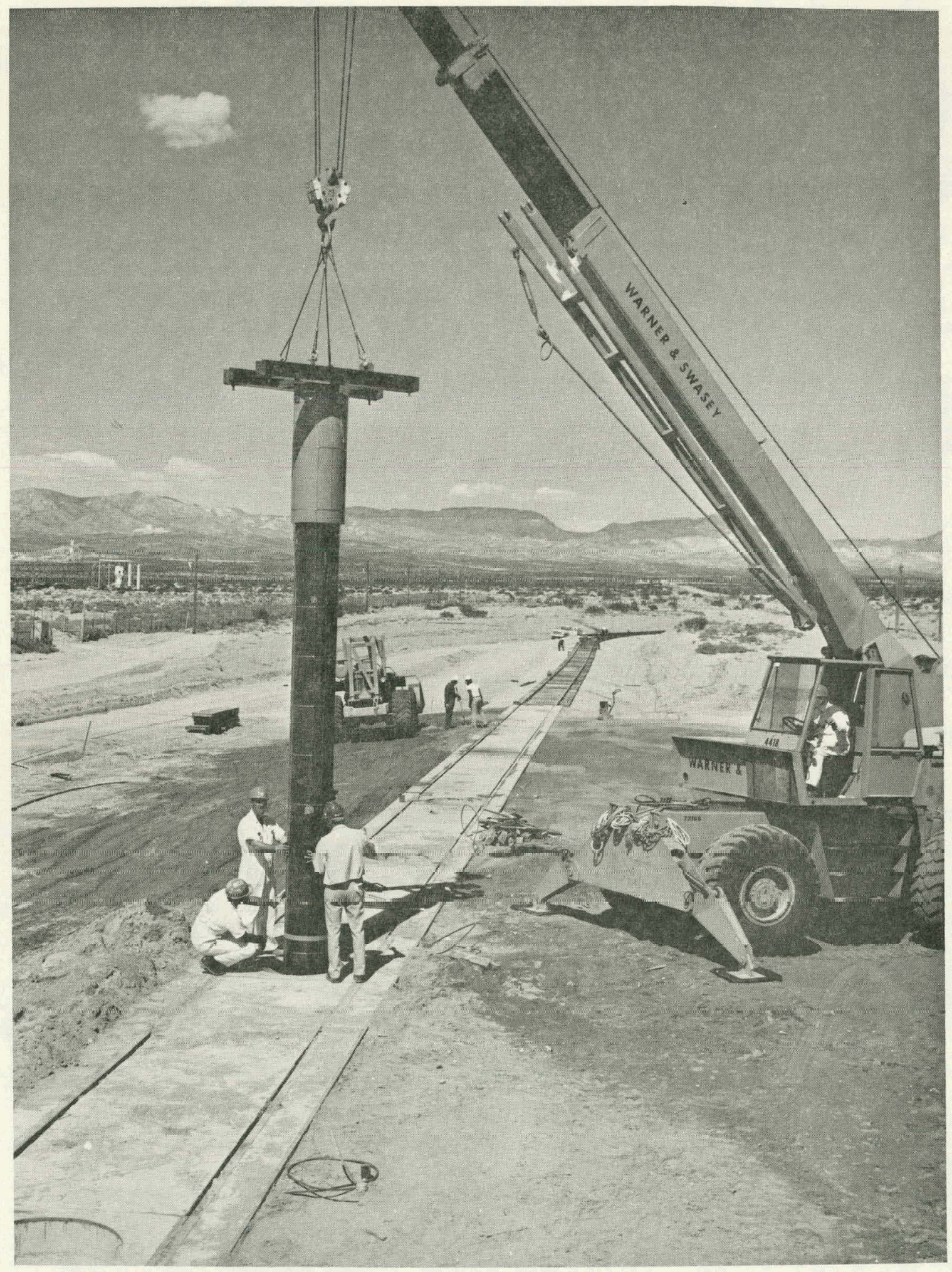

Figure A-5. Drywell Liner Installation Into Storage Area 

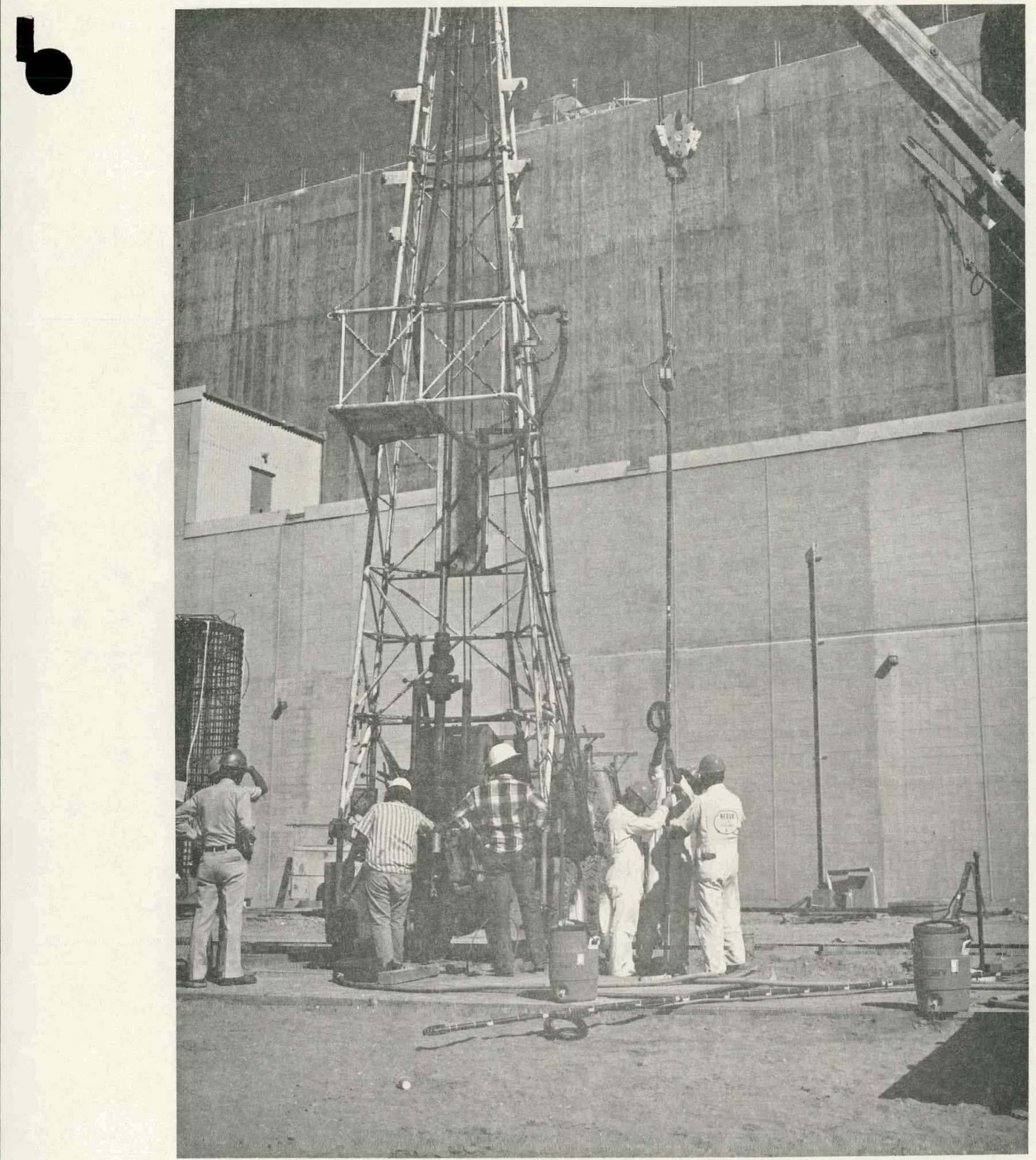

Figure A-6. Instrumentation Well Installation 


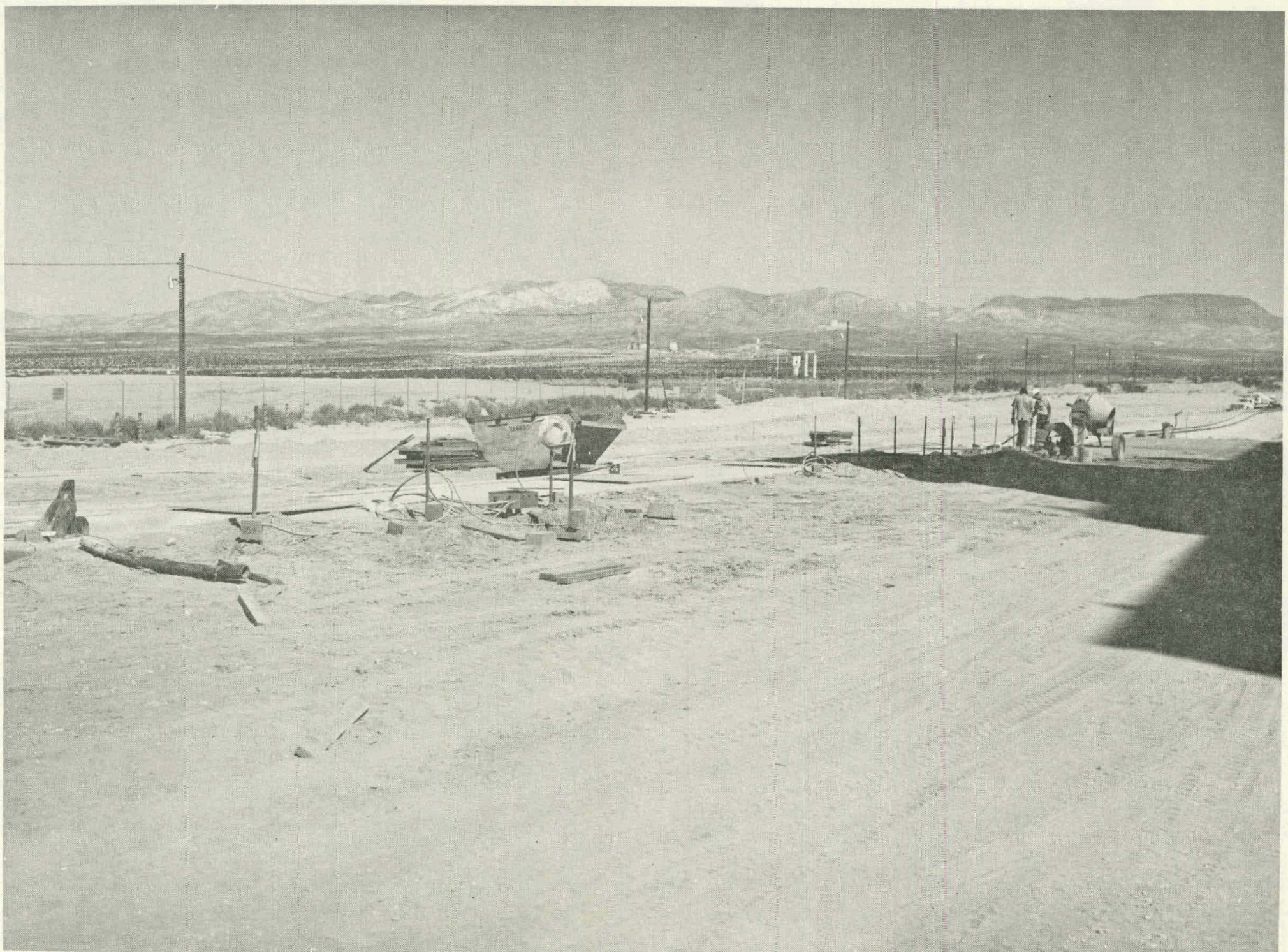

Figure A-7. Instrumentation We11s Installed in Drywe11 Storage Area 


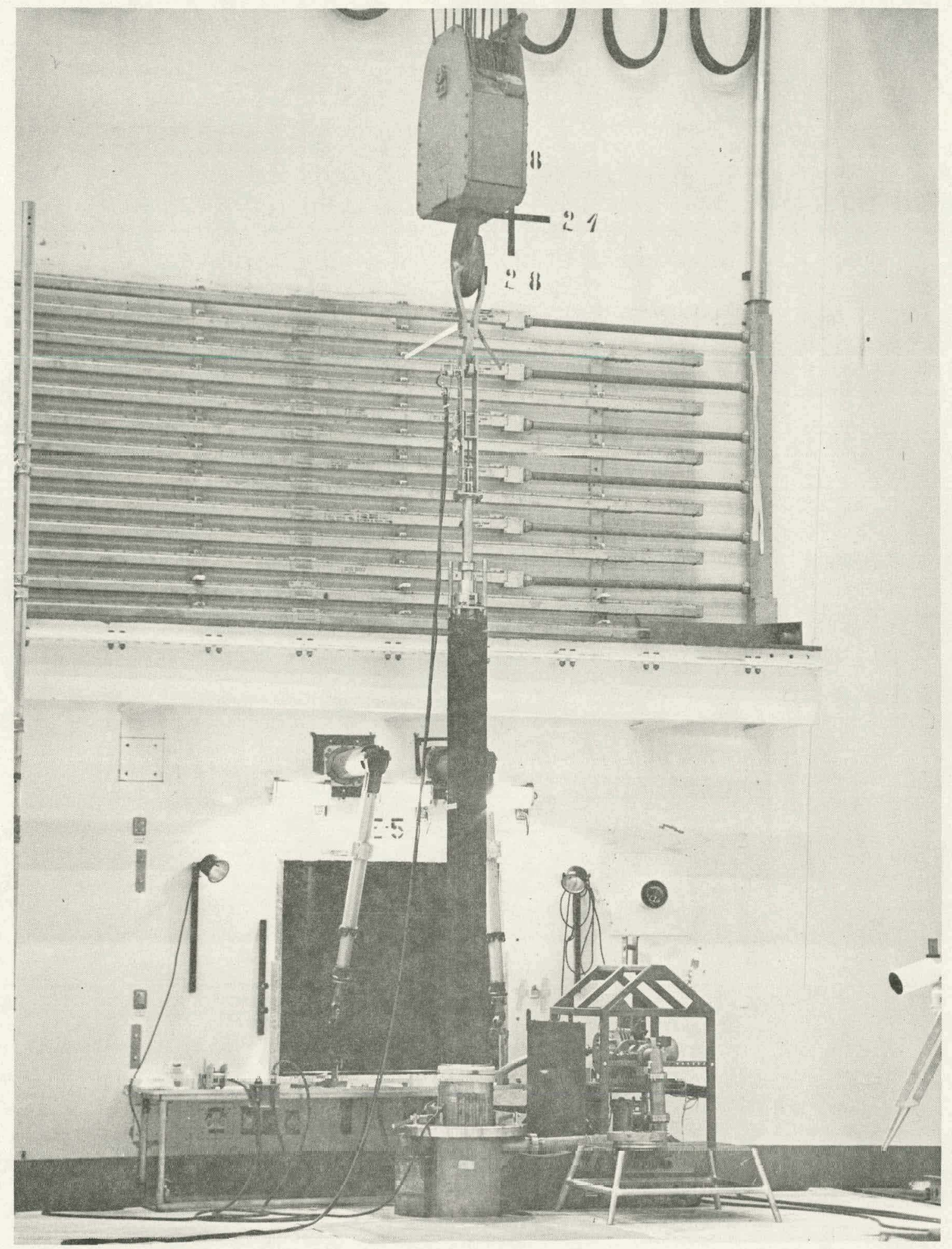

Figure A-8. PWR Fuel Assembly Being Installed Into Canister 


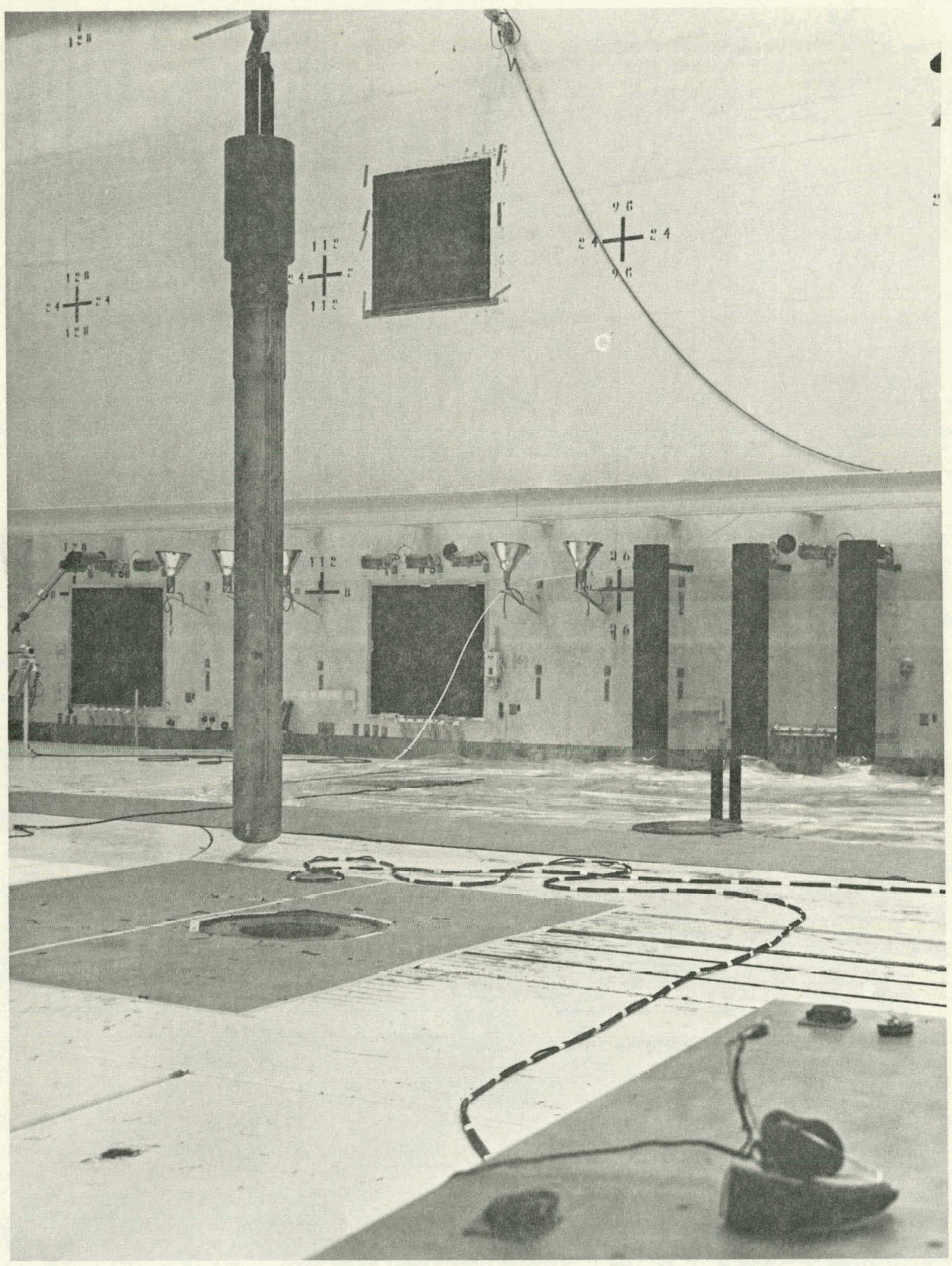

Figure A-9. Placing Completed Canister Assembly in Hot Bay Transfer Pit 


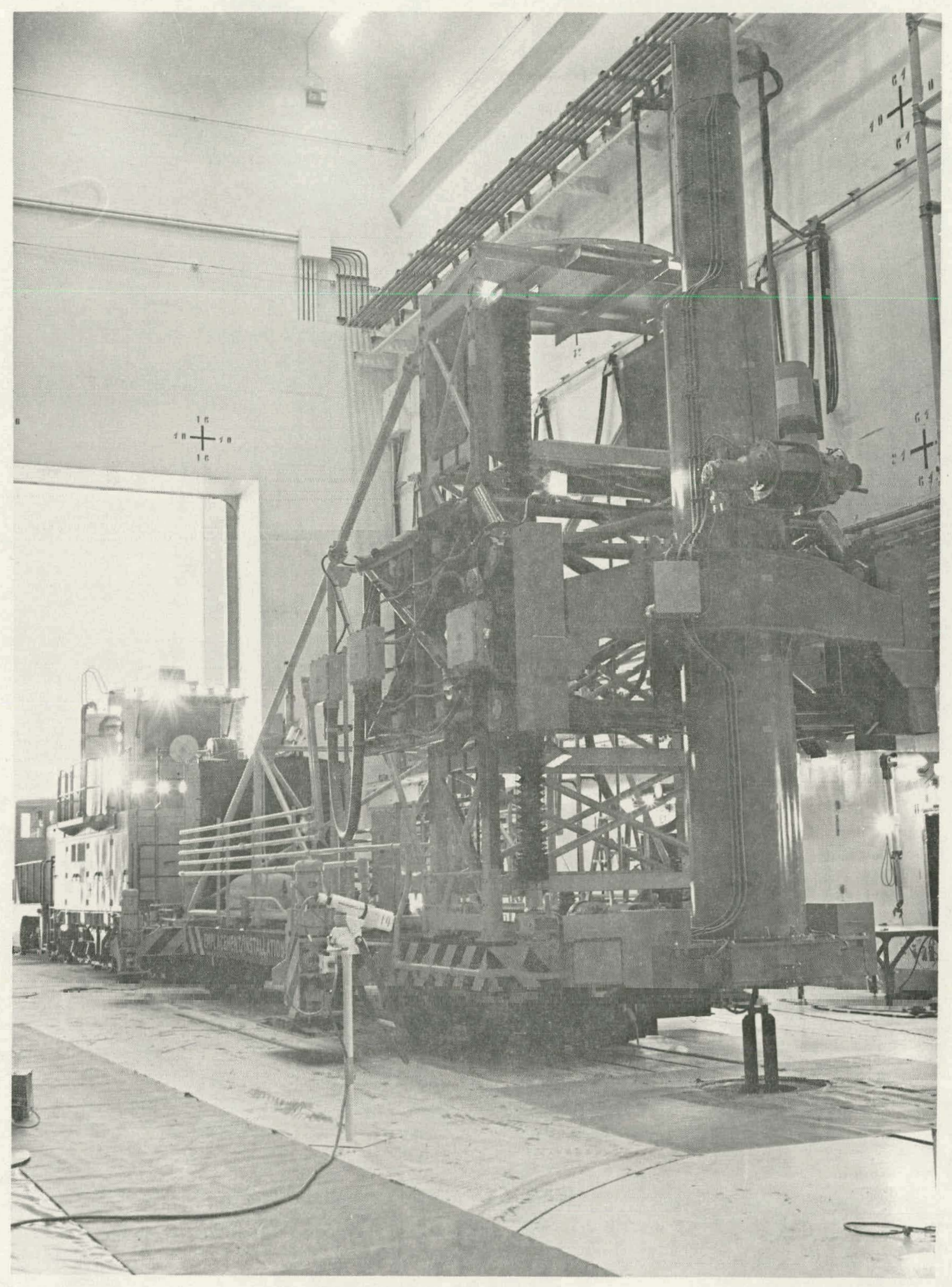

Figure A-10. Positioning Transfer Cask Over Hot Bay Transfer 


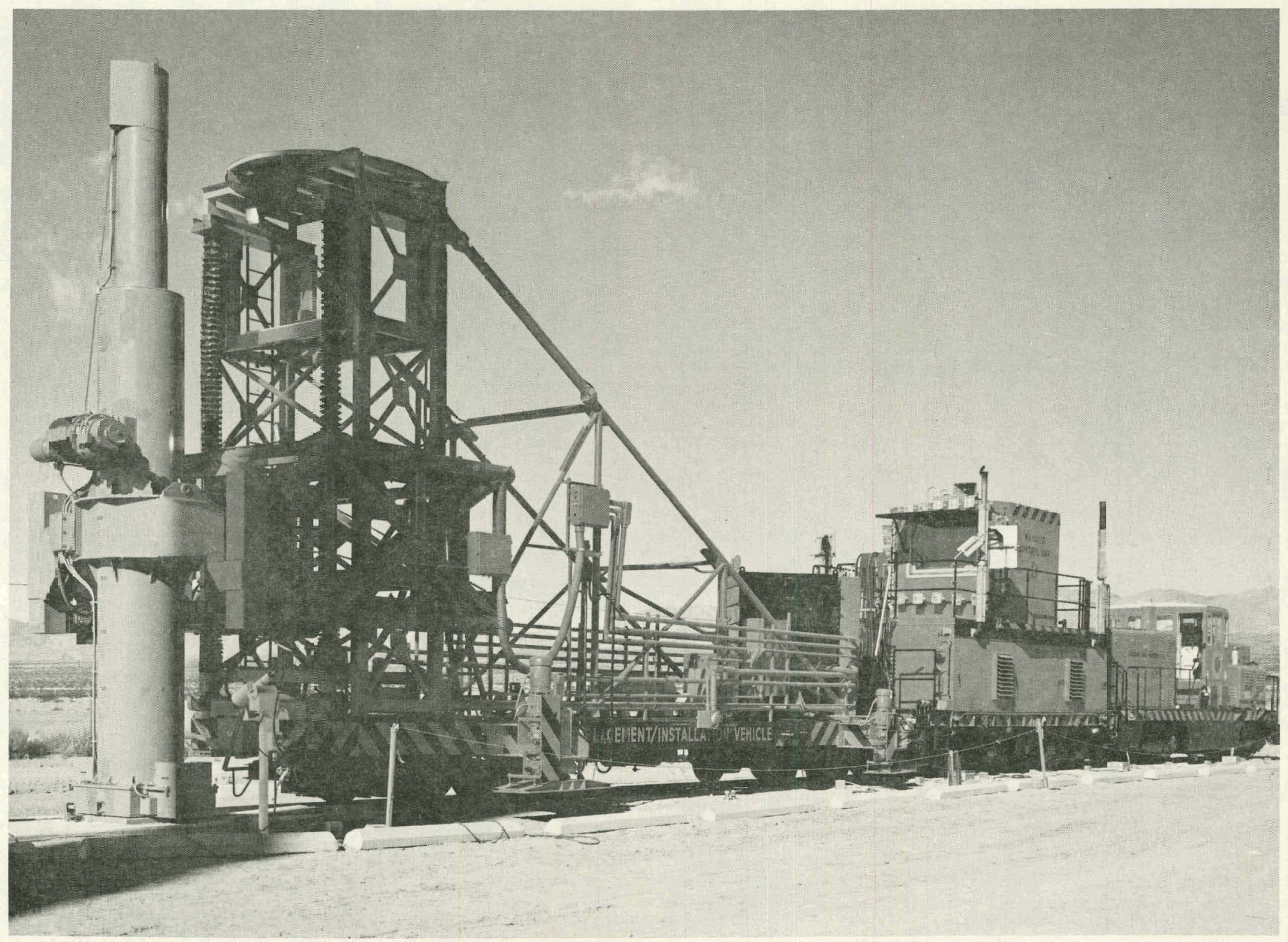

Figure A-11. Transfer Shield Positioned Over Drywell Emplacing Canister Assembly in Drywell 


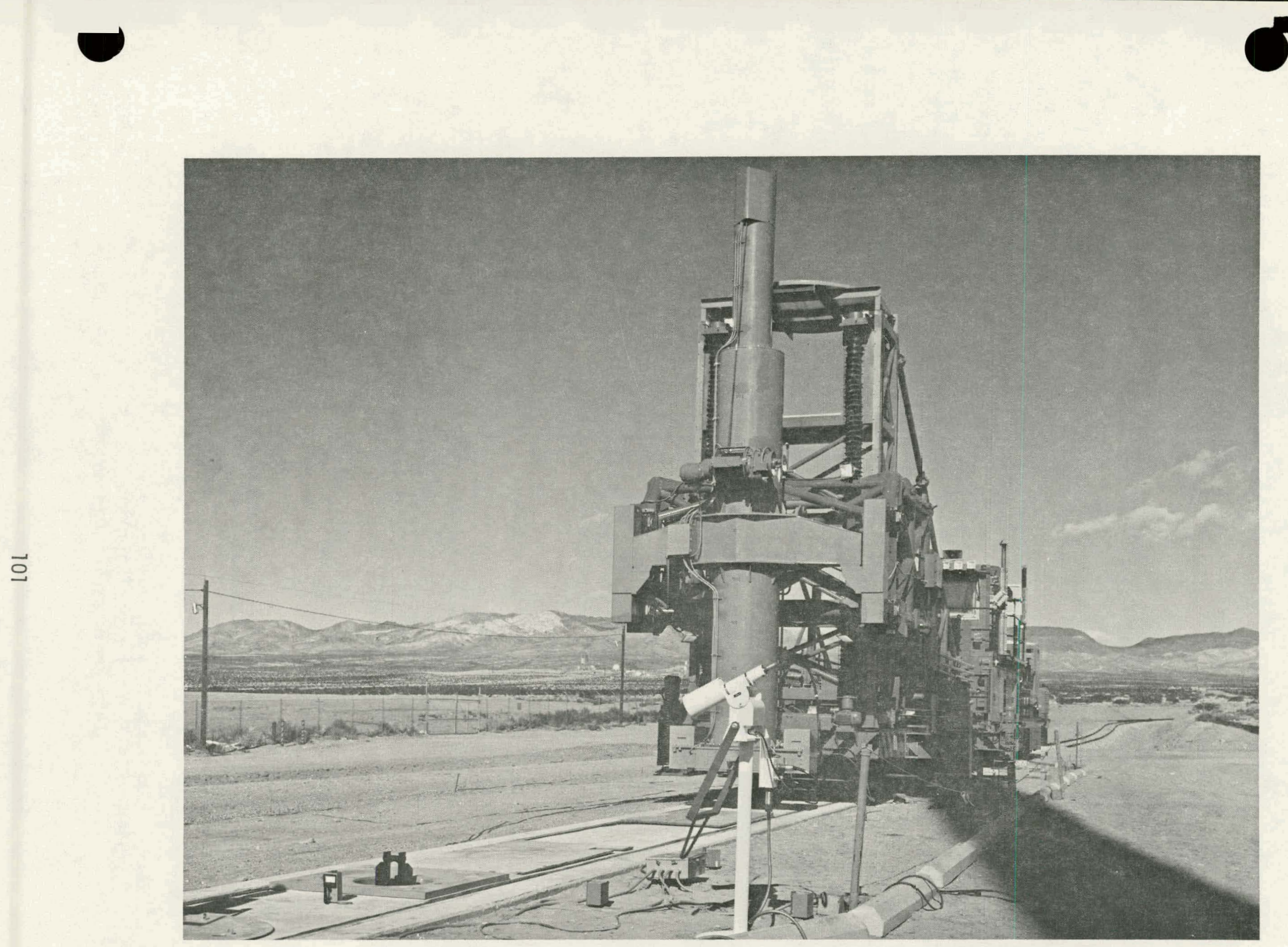

Figure A-12. Transfer of Canister to Drywe1l Completed 


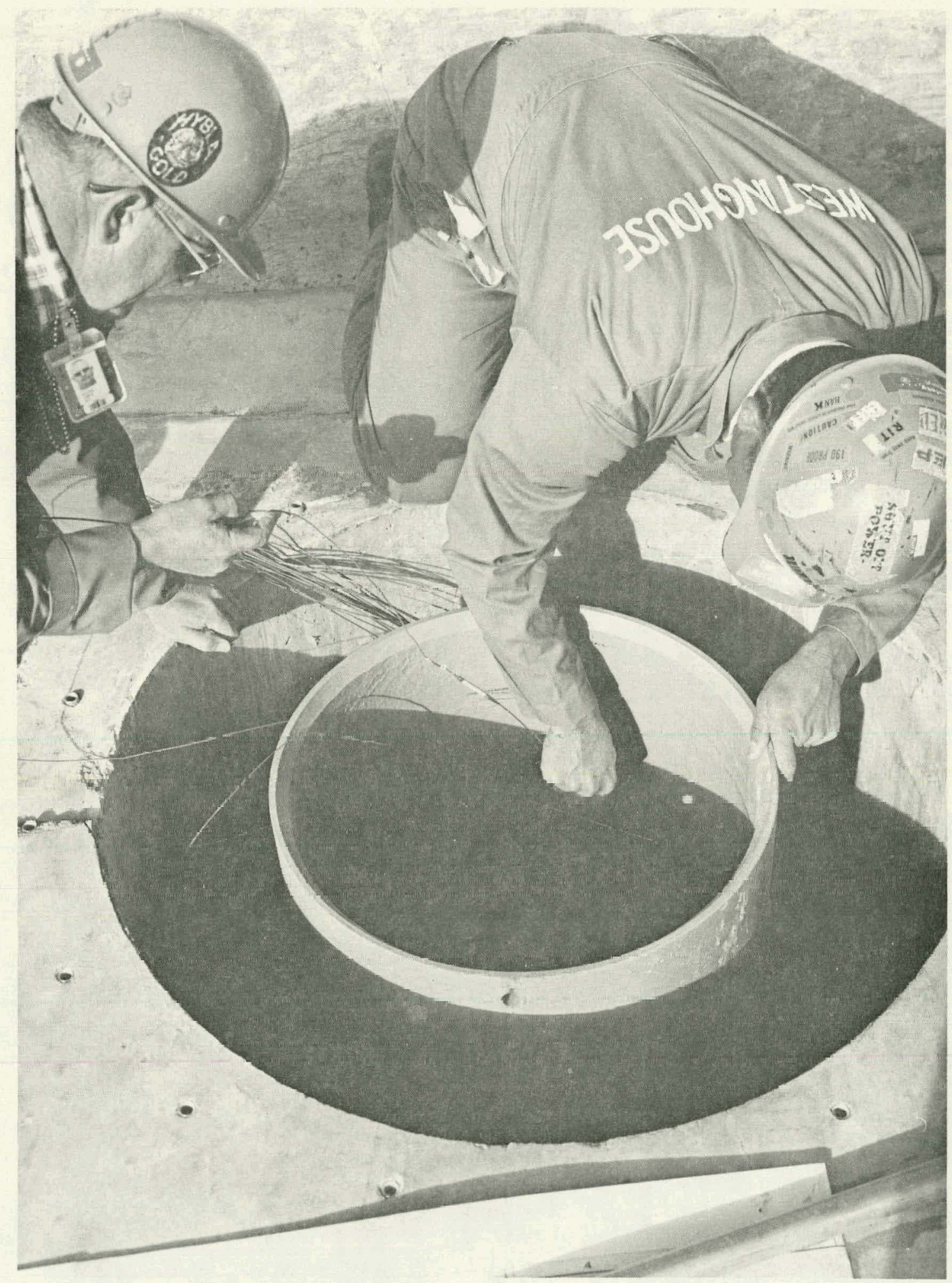

Figure A-13. Insertion of Thermocouples Into Drywell and Into Canister Through Shield Plug 


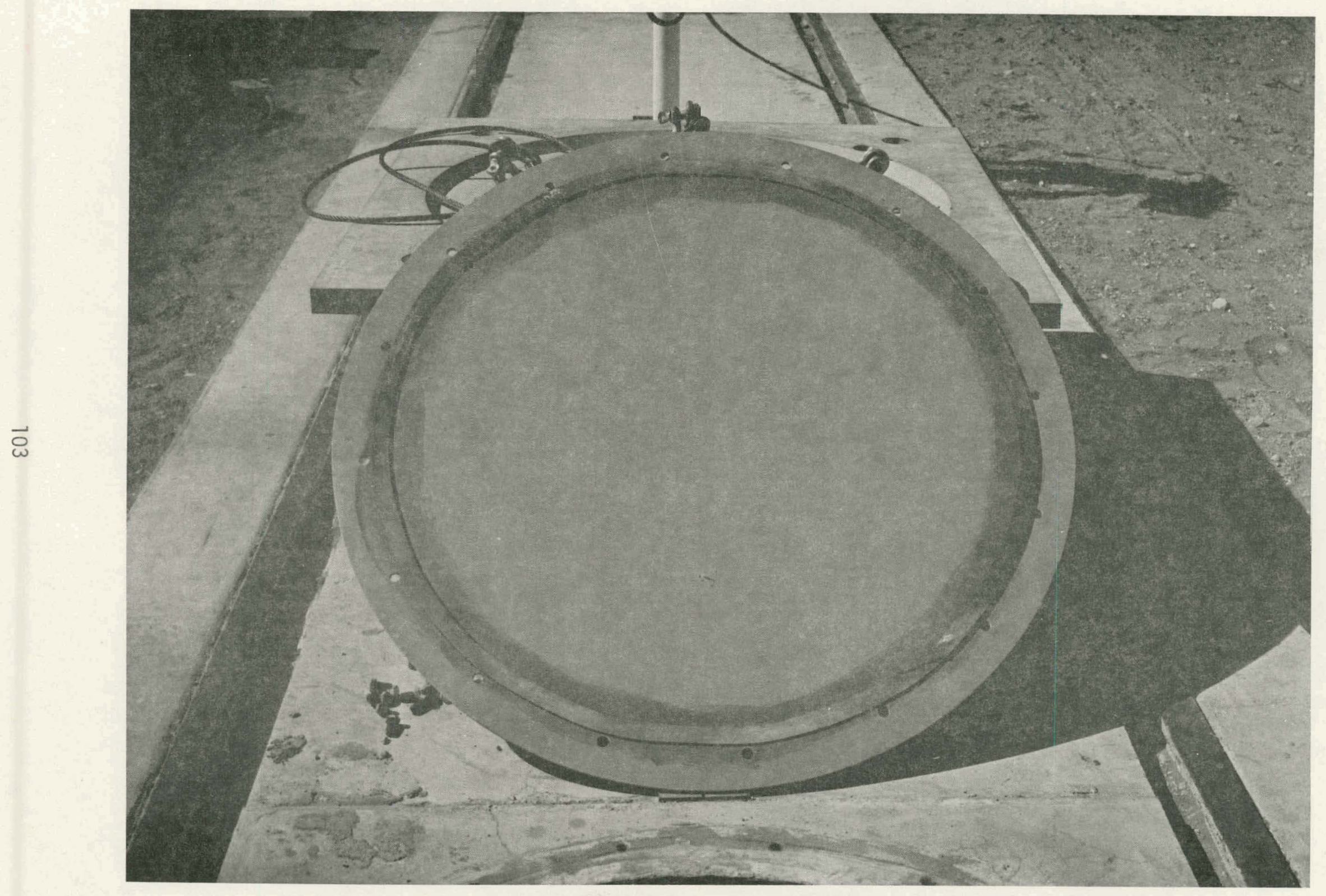

Figure A-14. Drywell Cover Plate Showing Neoprene Gasket 


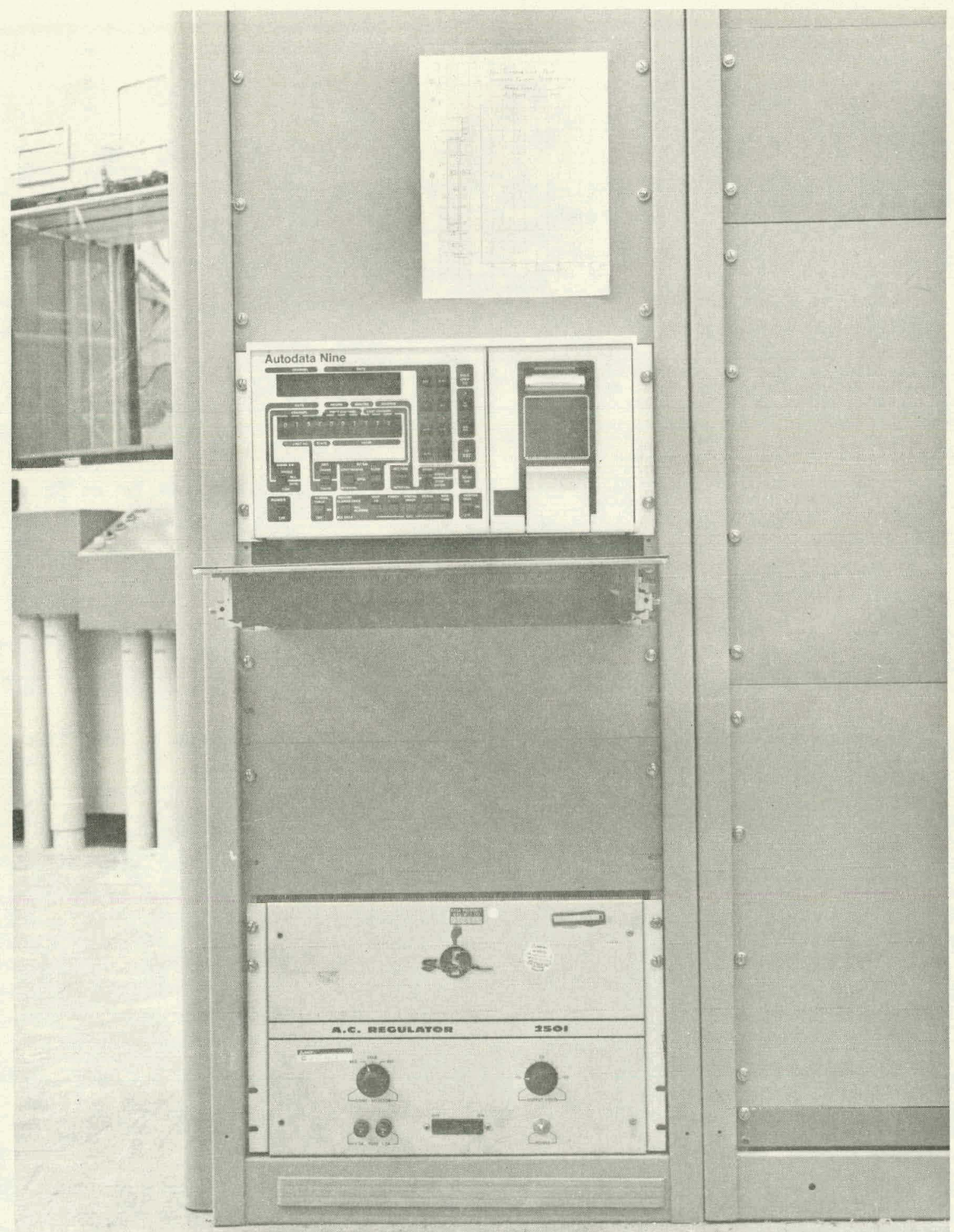

Figure A-15. Data Logger Installation in West Gallery 


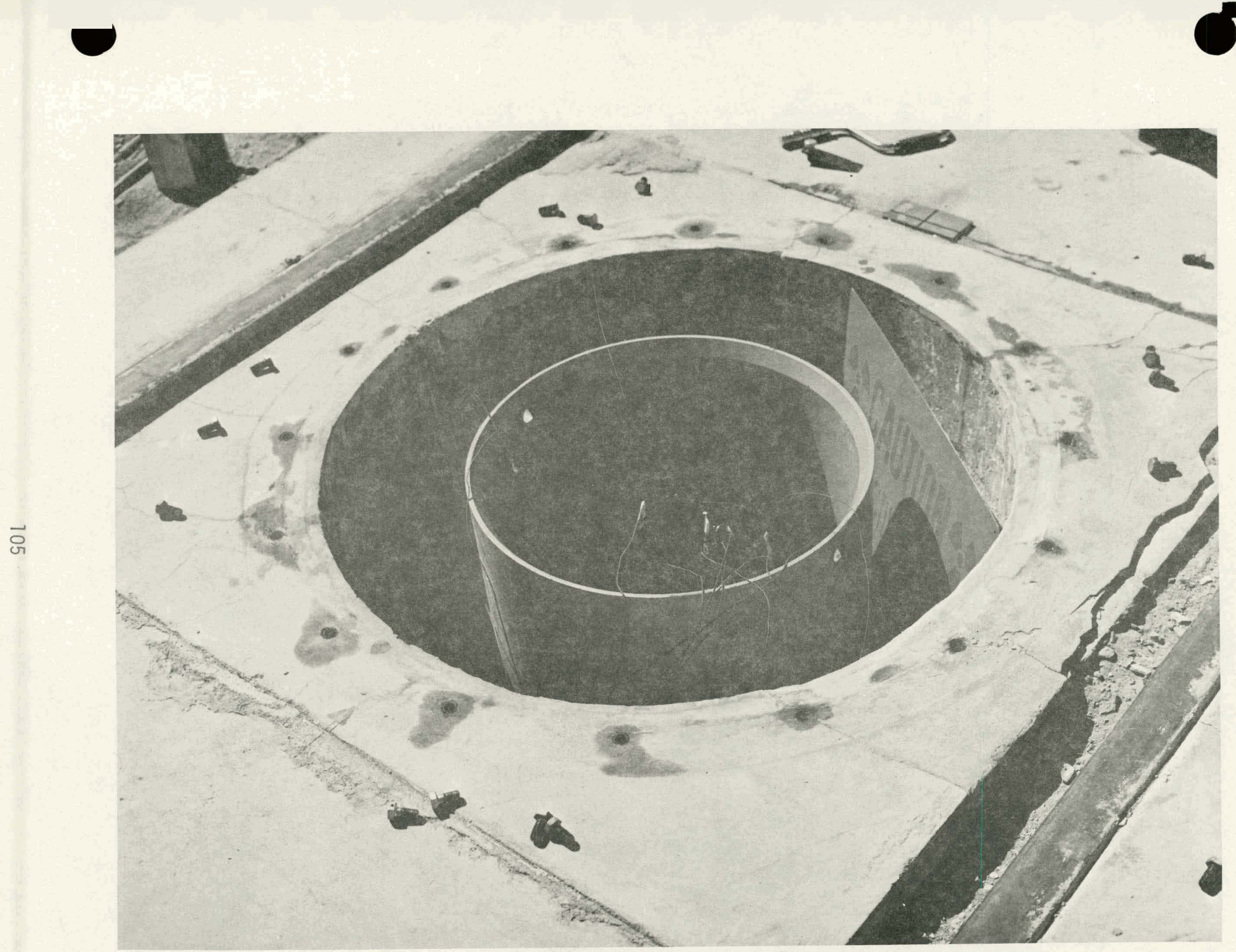

Figure A-16. Drywell 3 at End of Isolated Drywell Test With Cover Plate Removed 


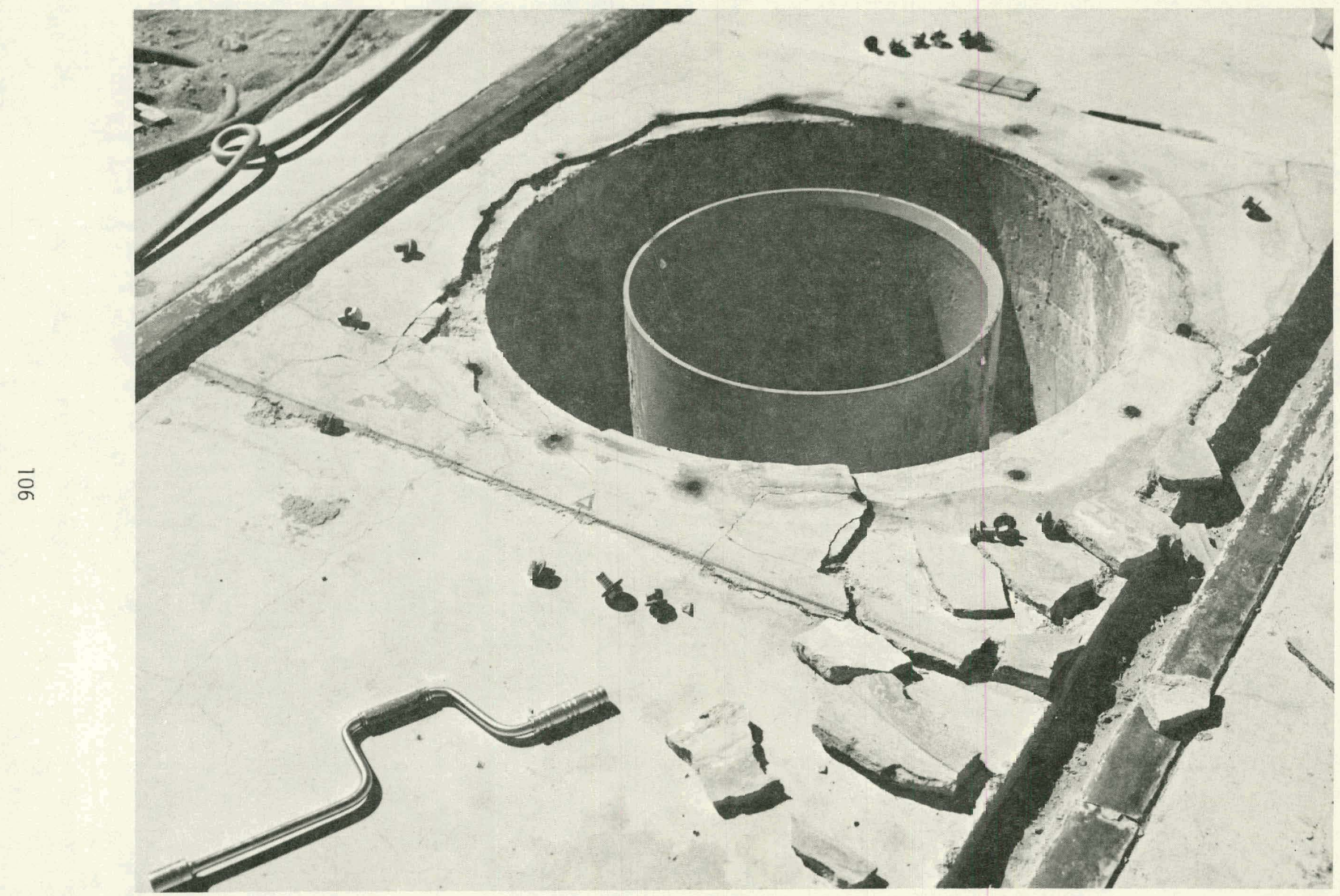

Figure A-17. Jrywe11 5 at End of Isolated Drywe11 Test With Cover Plate and Canister Removed 


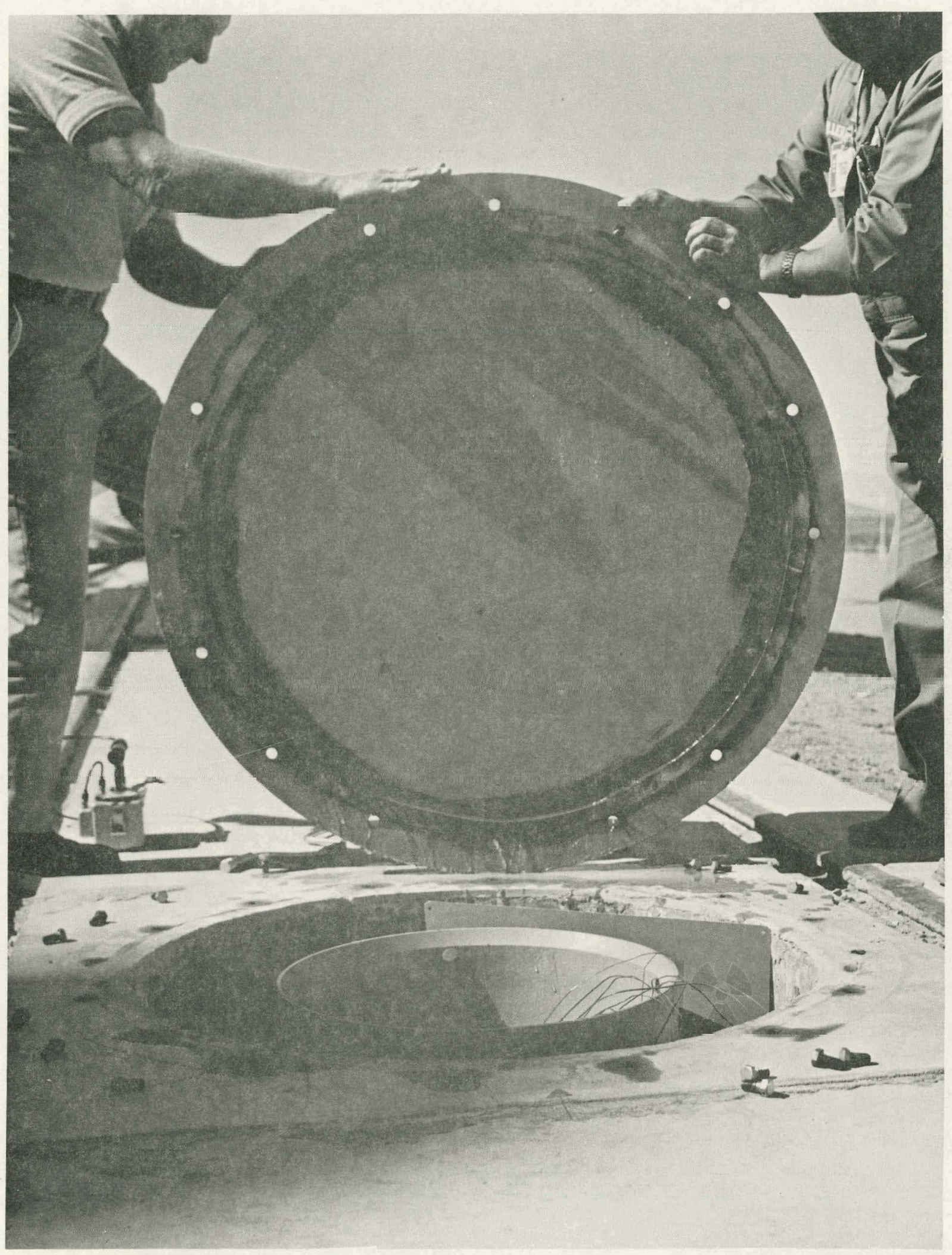

Figure A-18. Drywel1 3 Cover Plate Removed After Isolated Drywell Test 


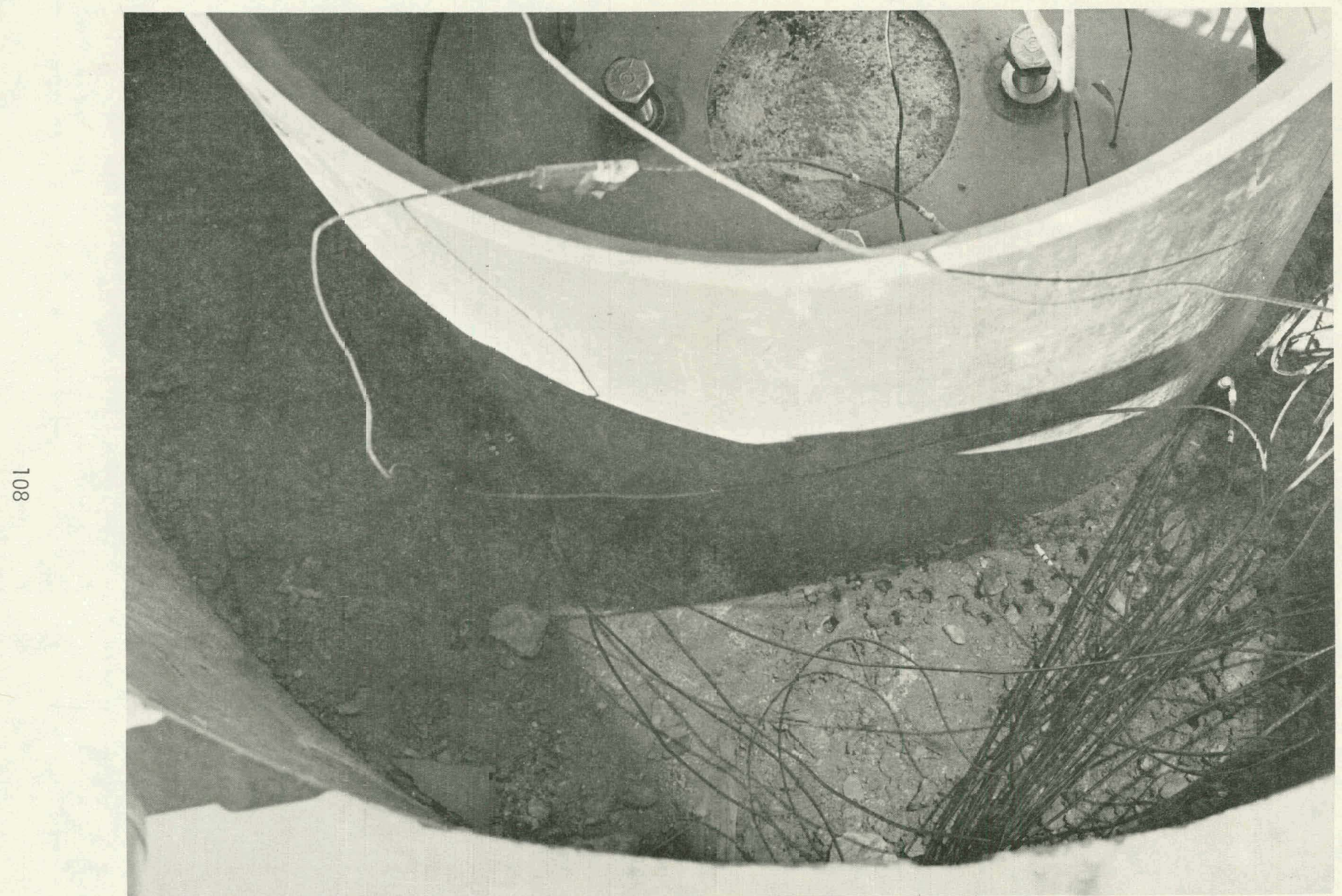

Figure A-19. Drywe1" 3 Concrete Fad Annulus 
APPENDIX B

ISOLATED DRYWELL TEST DATA

Test data are provided in this Appendix for the Isolated Drywell Test thermocouples. See Table 1 for the detailed identification and the location of the Isolated Drywe 11 Test thermocouples. Tables B-I through B-39 provide thermocouple readings at the times and for the test operating hours shown below:

Table
$B-1$
$B-2$
$B-3$
$B-4$
$B-5$
$B-6$
B-7
B-8
$B-9$
$B-10$
$B-11$
$B-12$
$B-13$.
$B-14$
$B-15$
$B-16$
B- 17
B-18
B- 19
B-20
$B-27$
B -22
$B-23$
B-24
$B-25$
$B-26$
$B-27$
B-28
B-29

Date

$1 / 12 / 79$

$1 / 25 / 79$

$2 / 1 / 79$

$2 / 15 / 79$

$3 / 1 / 79$

$3 / 15 / 79$

$4 / 1 / 79$

$4 / 15 / 79$

$5 / 1 / 79$

$5 / 16 / 79$

$6 / 1 / 79$.

$6 / 15 / 79$

$7 / 1 / 79$

$7 / 15 / 79$

$8 / 1 / 79$

$8 / 15 / 79$

$9 / 1 / 79$

$9 / 15 / 79$

$10 / 1 / 79$

$10 / 15 / 79$

$11 / 1 / 79$

$11 / 15 / 79$

$12 / 1 / 79$

$12 / 15 / 79$

$1 / 1 / 80$

$1 / 15 / 80$

$2 / 1 / 80$

$2 / 15 / 80$

$3 / 1 / 80$

Operating Hours

Drywel15 Drywell 3

378

486

822

1158

1494

1902

2238

2622

2986

3366

3702

4086

4422

4830

5166

5574

5910

6294

6630

7038

7374

7758

8094

8502

8838

9246

9582

9942

5
173
509
845
1181
1589
1925
2309
2673
3053
3389
3773
4109
4517
4853
5261
5597
5981
6317
6725
7061
7445
7781
8189
8525
8933
9269
9629




\section{$\underline{\text { Table }}$}

\section{$B-30$}

$B-31$

$\mathrm{B}-32$

B-33

$B-34$

$B-35$

$B-36$

$B-37$

$\mathrm{B}-38$

B-39
Date

$3 / 15 / 80$

$4 / 1 / 80$

$4 / 15 / 80$

$5 / 1 / 80$

$5 / 14 / 80$

$5 / 28 / 80$

$6 / 11 / 80$

$6 / 25 / 80$

$7 / 16 / 80$

$7 / 30 / 80$
Operating Hours

Drywe115 Drywell :3

10,278

9965

10,686

11,022

11,406

11,718

12,054

12,390

12,726

13,230

13,566
10,373

10,709

11,093

11,405

11,741

12,077

12,413

12,917

13,253 


\author{
TABLE B-1
}

ISOLATED DRYWELL TEST \& THERMOCOUPLE DATA

DATE : $1 / 12 / 79$

OPERATING HOURS: DRYWELL NO. 5: 6
TIME: 4:00 p.m.

DRYWELL NO. 3: N/A

\title{
THERMOCOUPLE READINGS
}

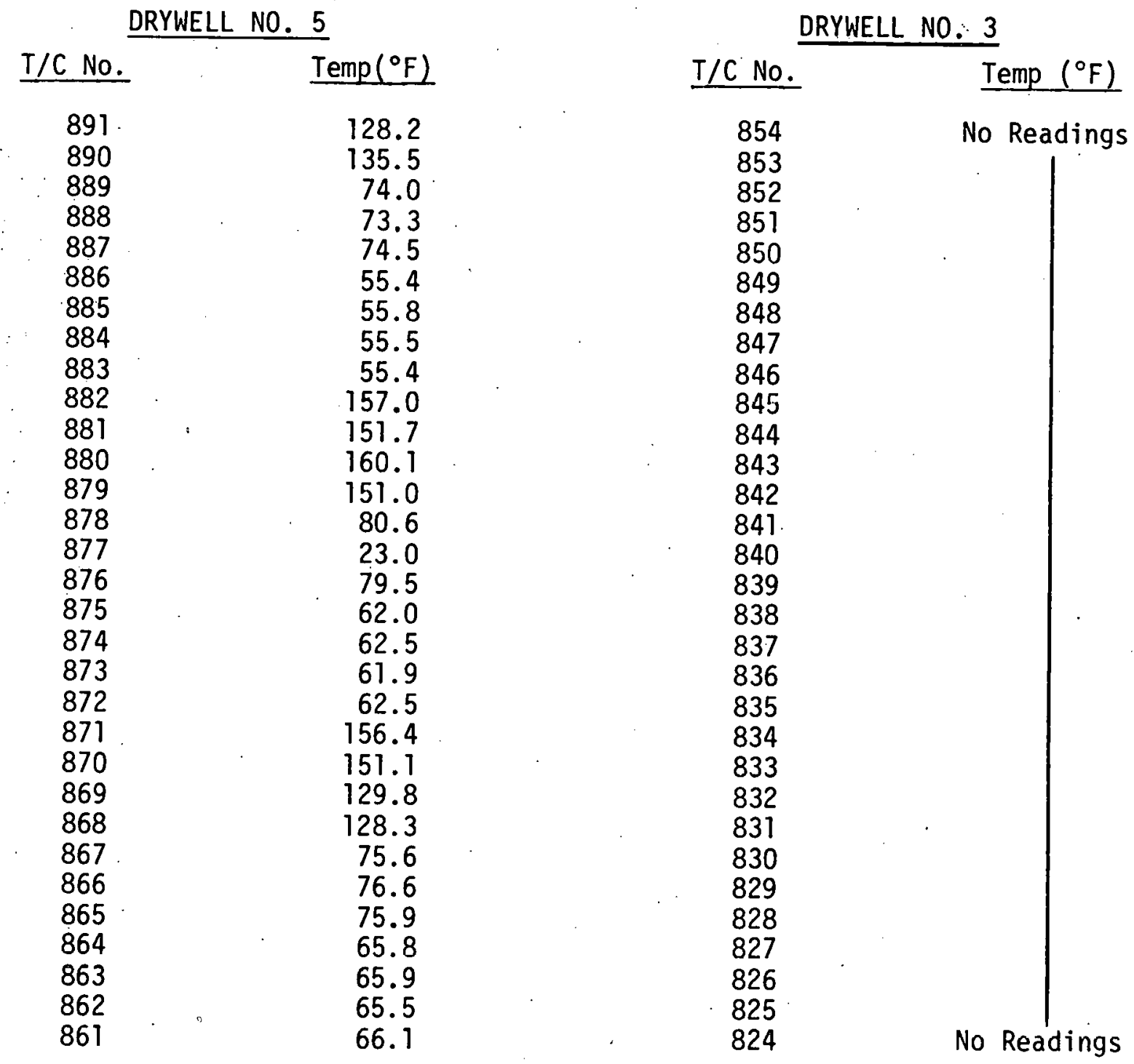


TABLE B-2

ISOLATED DRYWELL TEST - THERMOCOUPLE DATA

DATE: $1 / 25 / 79$

OPERATING HOURS: DRYWELL NO. 5: 318
TIME: $4: 00$ p.m.

DRYWELL NO. $3: .5$

\section{THERMOCOUPLE READINGS}

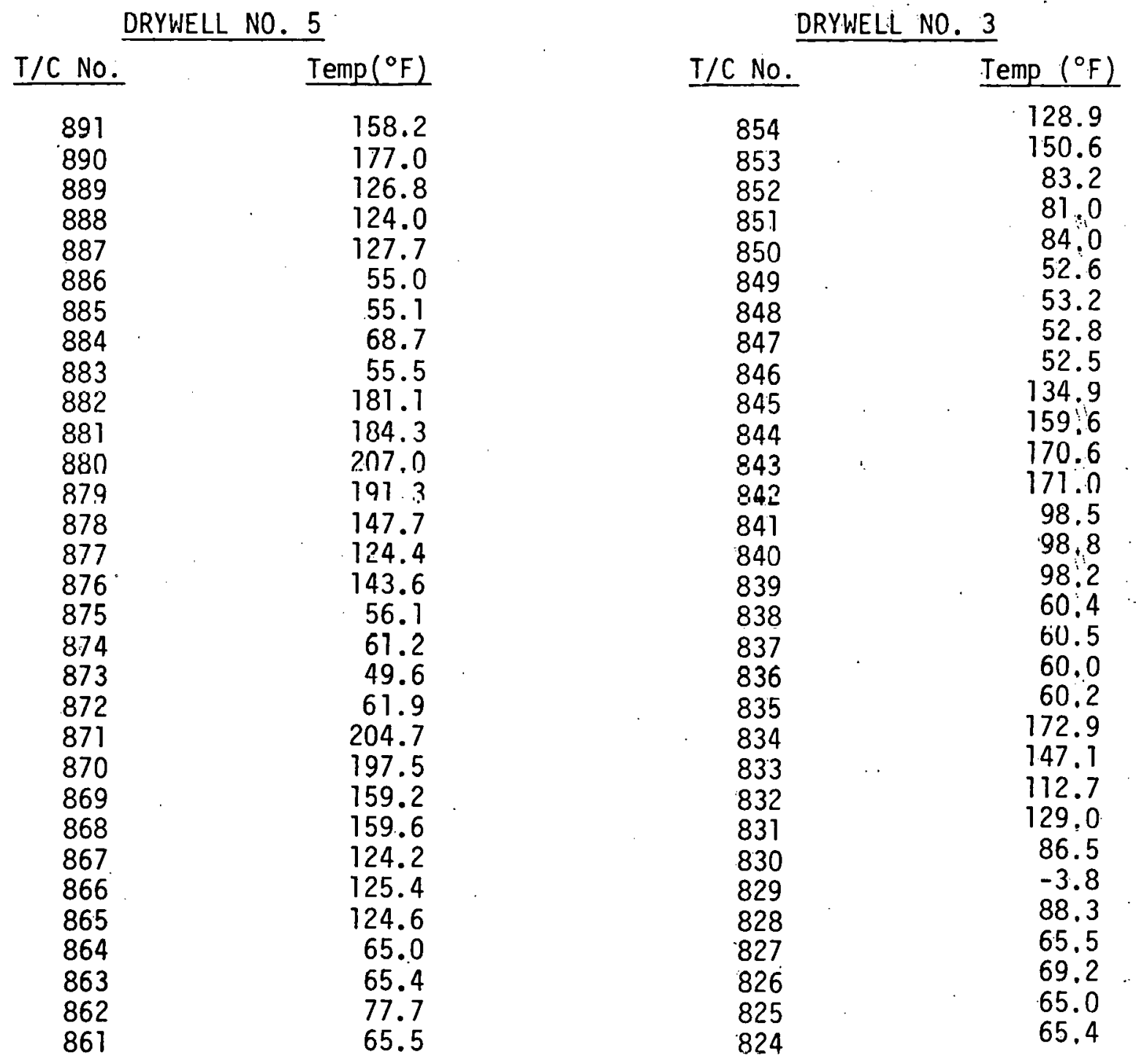

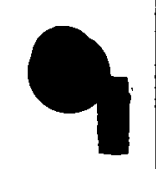


TABLE B-3

ISOLATED DRYWELL TEST - THERMOCOUPLE DATA

DATE : $\quad 2 / 1 / 79$

OPERATING HOURS: ' DRYWELL NO. 5: 486
TIME: $\quad 4: 00$ p.m.

DRYWELL NO. 3: 173

\section{THERMOCOUPLE READINGS}

DRYWELL NO. 5

T/C No.

891

890

889

888

887

886

885

884

883

882

881

880

879

878

877

876

875

874

873

872

871

870

869

868

867

866

865

864

863

862

861
Temp $\left({ }^{\circ} \mathrm{F}\right)$

161.4

188.0

130.8

127.7

131.8

54.5

55.0

64.6

54.6

183.9

189.3

200.5

208.0

154.1

129.9

152.6

60.9

61.4

73.9

61.3

216.5

215.7

162.5

154.5

129.6

131.0

130.1

65.0

65.1

73.7

65.3
DRYHELL NO. 3

T/C No.

854

853

852

851

850

849

848

847

846

845

844

843

842

841

840

839

838

837

836

835

834

833

832

831

830

829

828

827

826

825

824
Temp ( $\left.{ }^{\circ} \mathrm{F}\right)$

154.9

179.8

113.1

109.9

114.8

51.7

52.3

55.3

51.6

163.4

189.2

202.4

203.6

136.5

136.4

135.9

59.7

59.7

63.7

59.5

205.8

184.1

137.8

154.6

115.3

$-37.5$

117.2

64.8

64.9

67.5

64.8 
TABLE B-4

ISOLATED DRYWELL TEST - THERMOCOUPLE DATA

DATE: $2 / 15 / 79$

TIME: $\quad 4: 00$ p.m.

OPERATING HOURS: DRYWELL NO. 5: 822 DRYWELL NO. 3: 509

THERMOCOUPLE READINGS

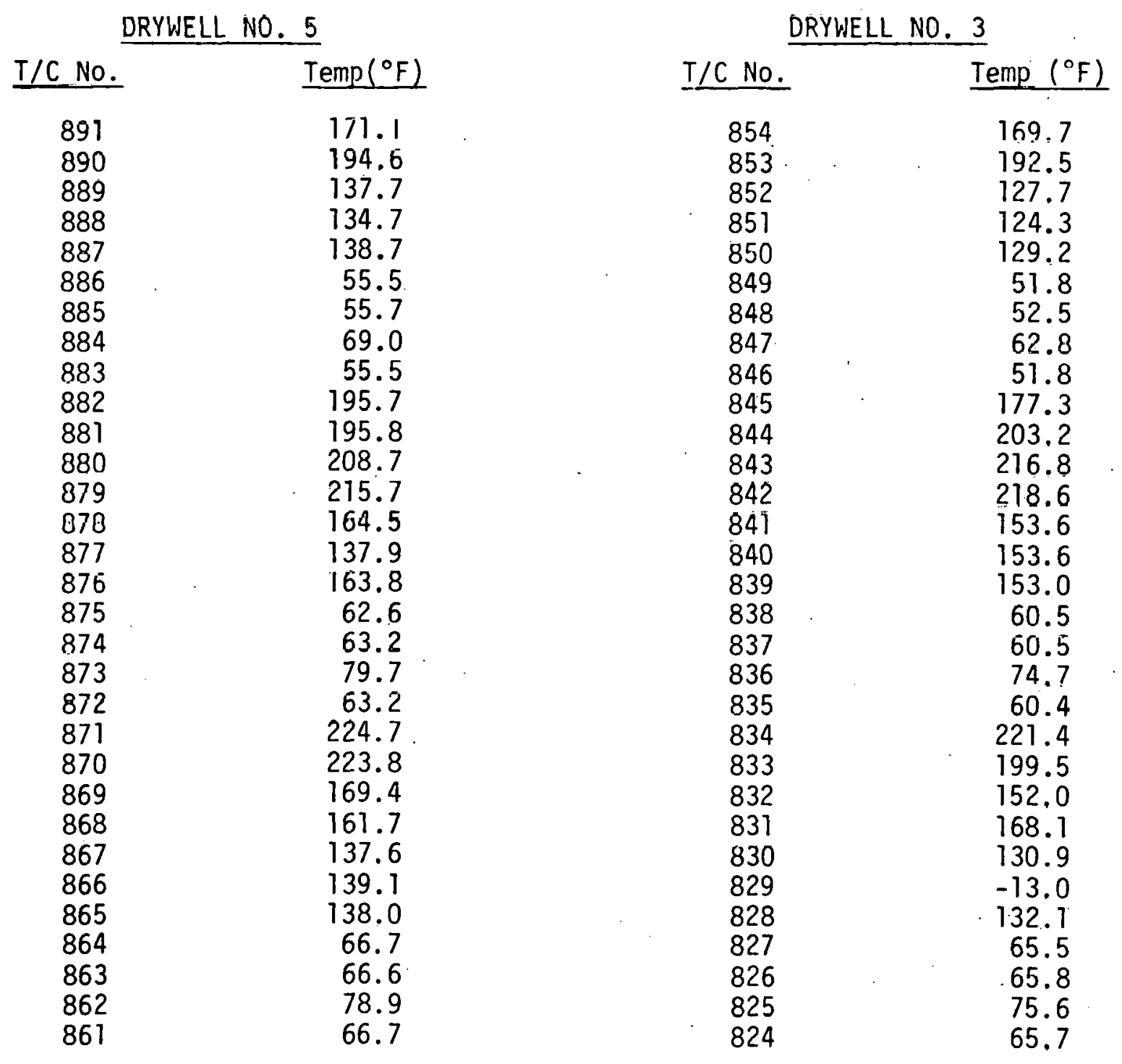


TABLE B-5

ISOLATED DRYWELL TEST - THERMOCOUPLE DATA

DATE : $3 / 1 / 79$

TIME: $4: 00$ p.m.

OPERATING HOURS: DRYWELL NO. 5: 1158 DRYWELL NO. 3: 845

THERMOCOUPLE READINGS

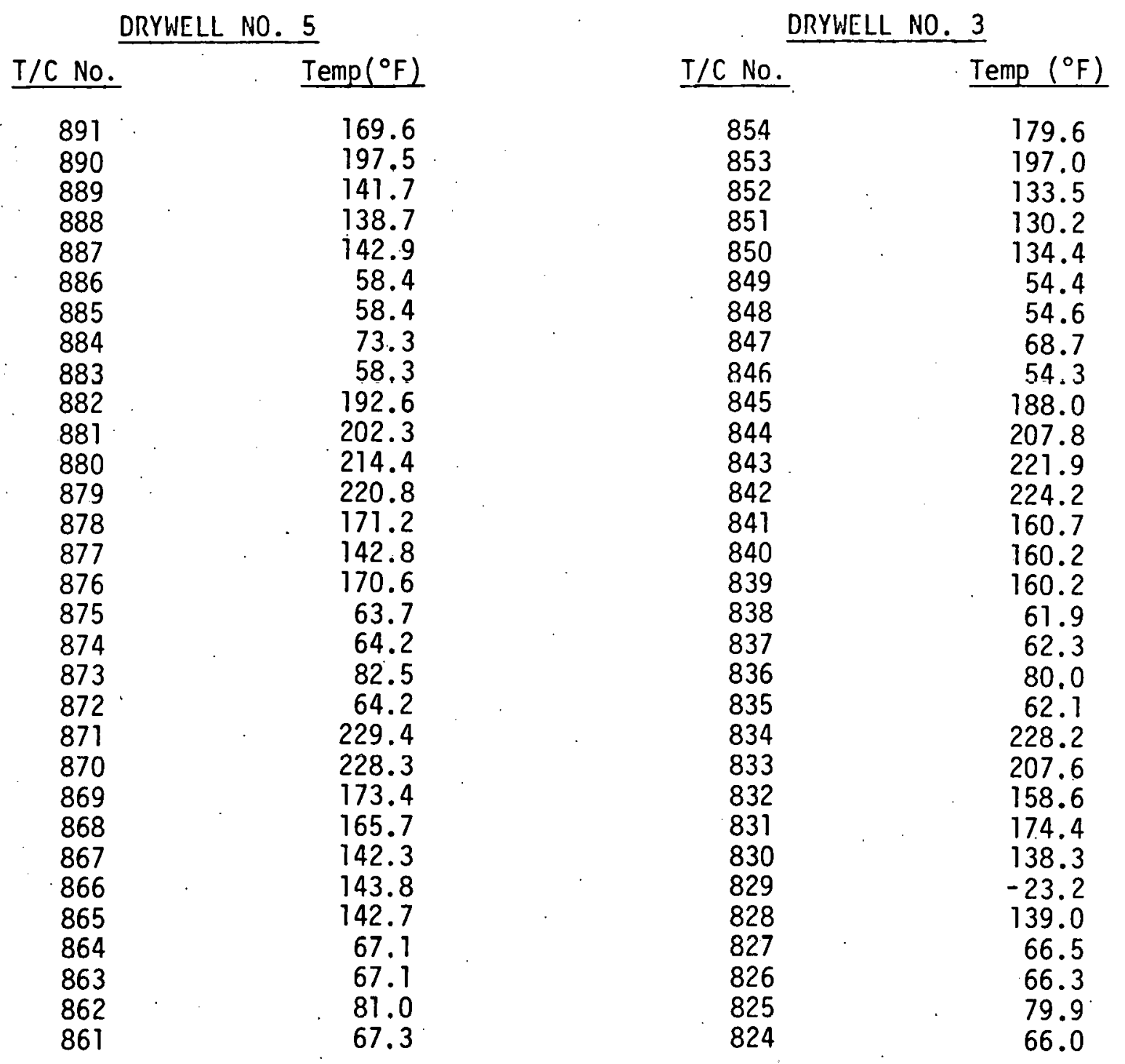


TABLE $\cdot B-6$

ISOLATED DRYWELL TEST - THERMOCOUPLE DATA

DATE: : $3 / 15 / 79$

OPERATING HOURS: DRYWELL NO. 5: 1494 DRYWELL NO. 3: 1181
TIME: $\quad 4: 00$ p.m.

\section{THERMOCOUPLE READINGS}

DRYWELL NO. 5

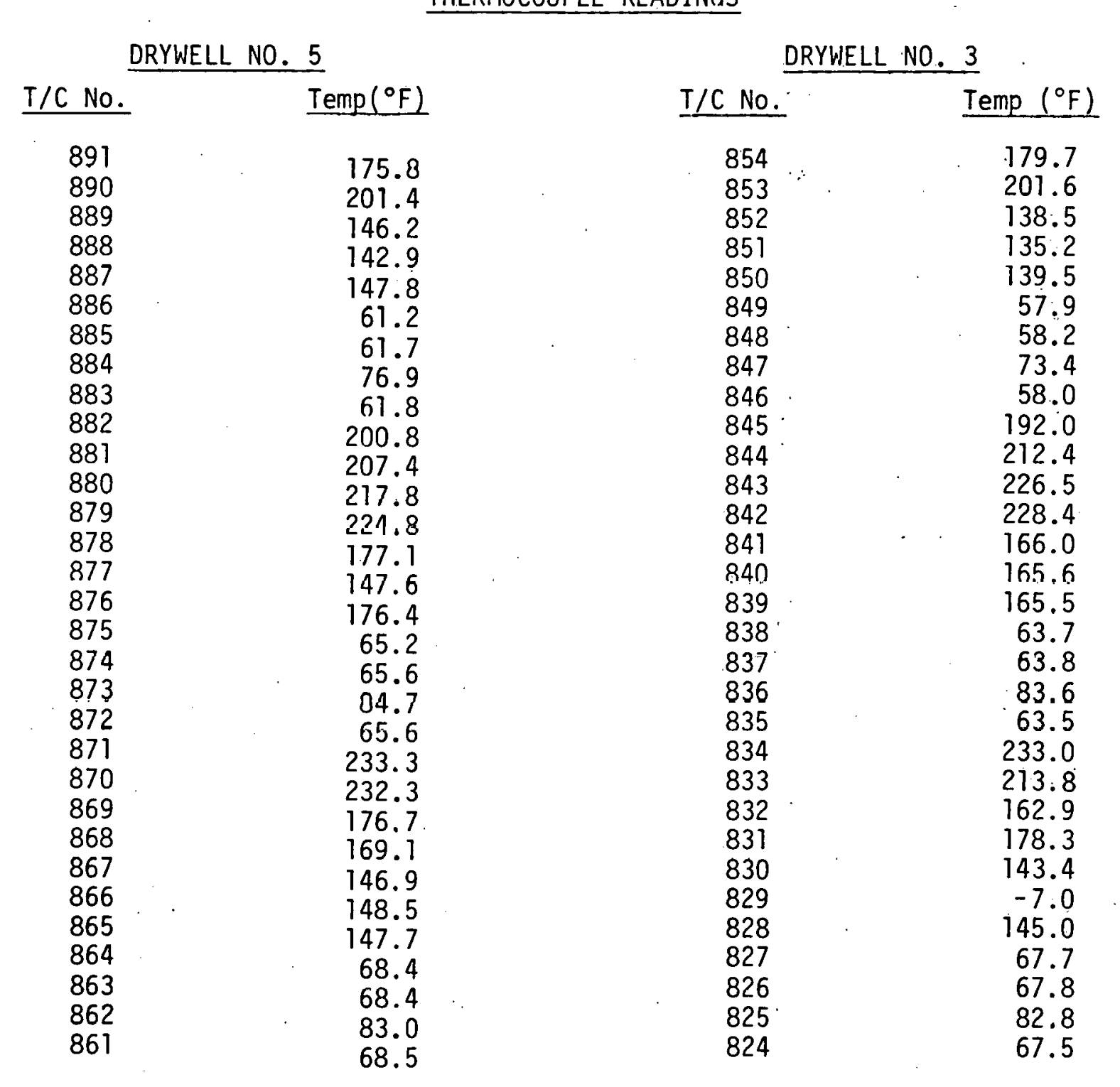

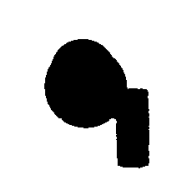


TABLE $\quad B-7$

ISOLATED DRYWELL TEST - THERMOCOUPLE DATA

DATE : $\quad 4 / 1 / 79$

OPERATING HOURS: DRYWELL NO. 5: 1902
TIME: 4:00 p.m.

DRYWELL NO. 3: $\quad 1589$

\section{THERMOCOUPLE READINGS}

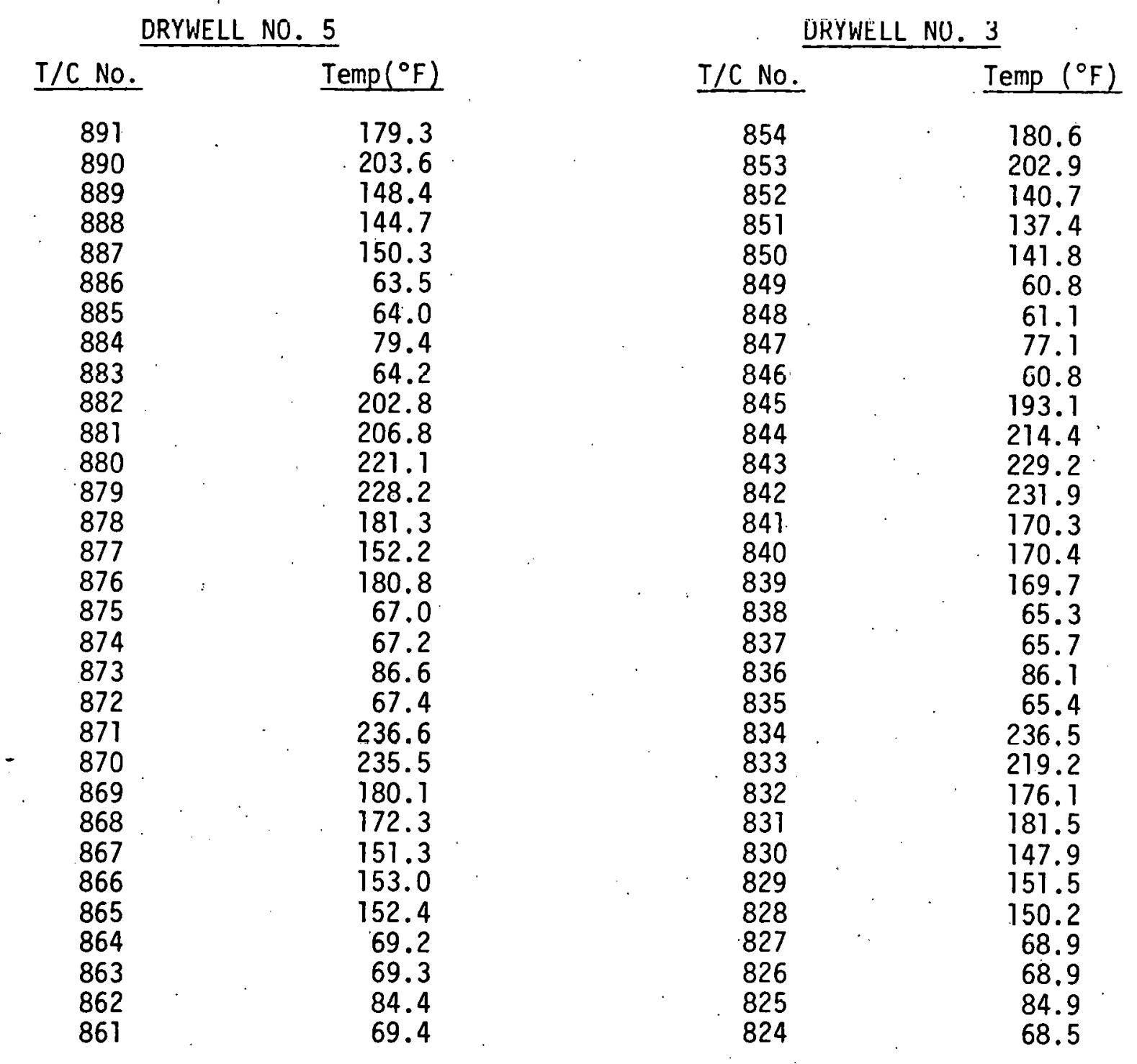


TABLE $\quad B-8$

ISOLATED DRYWELL TEST - THERMOCOUPLE DATA

DATE : $\quad 4 / 15 / 79$

OPERATING HOURS: DRYWELL NO. 5: 2238
TIME： 4:00 p.m.

DRYWELL NO. 3: 1925

\section{THERMOCOUPLE READINGS}

\begin{tabular}{cccc}
\multicolumn{2}{c}{ DRYWELL NO. 5} & \multicolumn{2}{c}{ DRYWELL NO. 3} \\
\cline { 2 - 3 } T/C No. & Temp $\left({ }^{\circ} \mathrm{F}\right)$ & T/C No. & Temp $\left({ }^{\circ} \mathrm{F}\right)$ \\
\hline 891 & 177.8 & 854 & 181.7 \\
890 & 205.8 & 853 & 205.3 \\
889 & 150.8 & 852 & 142.9 \\
888 & 147.0 & 851 & 139.5 \\
887 & 153.1 & 850 & 143.8 \\
886 & 65.7 & 849 & 63.0 \\
885 & 66.3 & 848 & 63.0 \\
884 & 81.7 & 847 & 79.4 \\
883 & 66.5 & 846 & 62.9 \\
882 & 208.7 & 845 & 196.2 \\
881 & 211.6 & 844 & 217.0 \\
880 & 224.1 & 843 & 232.0 \\
879 & 230.6 & 842 & 234.5 \\
878 & 184.7 & 841 & 173.4 \\
877 & 155.3 & 840 & 174.2 \\
876 & 184.1 & 839 & 173.7 \\
875 & 68.3 & 838 & 67.1 \\
874 & 68.5 & 837 & 67.5 \\
873 & 87.7 & 836 & 88.1 \\
872 & 68.6 & 835 & 67.3 \\
871 & 238.9 & 834 & 239.7 \\
870 & 237.6 & 833 & 221.1 \\
869 & 182.1 & 832 & 178.8 \\
868 & 174.6 & 831 & 184.2 \\
867 & 154.3 & 830 & 151.6 \\
866 & 155.9 & 829 & 154.9 \\
865 & 155.4 & 828 & 153.4 \\
864 & 69.9 & 827 & 69.8 \\
863 & 70.0 & 826 & 69.8 \\
862 & 85.1 & 824 & 69.1 \\
861 & 70.1 & &
\end{tabular}


TABLE $\quad B-9$

ISOLATED DRYWELL TEST - THERMOCOUPLE DATA

DATE : 5/1/79 TIME: 4:00 p.m.

OPERATING HOURS: DRYWELL NO. 5: 2622 DRYWELL NO. 3: 2309

\section{THERMOCOUPLE READINGS}

DRYWELL NO. 5

\begin{tabular}{cccc} 
T/C No. & Temp $\left({ }^{\circ} \mathrm{F}\right)$ & T/C No. & Temp $\left({ }^{\circ} \mathrm{F}\right)$ \\
\cline { 2 - 3 } 891 & 195.2 & 854 & 192.7 \\
890 & 205.9 & 853 & 202.9 \\
889 & 149.4 & 852 & 143.2 \\
888 & 146.4 & 851 & 139.9 \\
887 & 151.6 & 850 & 144.5 \\
886 & 69.1 & 849 & 66.7 \\
885 & 69.5 & 848 & 66.4 \\
884 & 84.9 & 847 & 82.9 \\
883 & 69.9 & 846 & 66.3 \\
882 & 224.9 & 845 & 215.1 \\
881 & 226.3 & 844 & 221.4 \\
880 & 240.1 & 843 & 233.3 \\
879 & 235.4 & 842 & 235.0 \\
878 & 187.2 & 841 & 177.4 \\
877 & 166.1 & 840 & 177.9 \\
876 & 185.5 & 839 & 177.0 \\
875 & 69.5 & 838 & 68.5 \\
874 & 69.8 & 837 & 68.8 \\
873 & 88.9 & 836 & 89.5 \\
872 & 70.0 & 835 & 68.7 \\
871 & 244.4 & 834 & 244.2 \\
870 & 242.7 & 833 & 241.3 \\
869 & 202.7 & 832 & 203.1 \\
868 & 204.9 & 831 & 203.5 \\
867 & 165.3 & 830 & 162.9 \\
866 & 167.0 & 829 & 167.1 \\
865 & 165.7 & 828 & 163.3 \\
864 & 70.5 & 827 & 70.5 \\
863 & 70.5 & 826 & 70.6 \\
862 & 85.8 & 825 & 86.9 \\
861 & 70.7 & 824 & 70.3 \\
& & &
\end{tabular}


TABLE B-10

ISOLATED DRYWELL TEST - THERMOCOUPLE DATA

DATE : $\quad 5 / 16 / 79$

TIME： 8:00 a.m.

OPERATING HOURS: DRYWELL N0. 5: 2986 DRYWELL N0. 3: 2673

THERMOCOUPLE READINGS

DRYYWELL NO. 5

\section{T/C No.}

891

890

889

888

887

886

885

884

883

882

881

880

879

878

877

876

875

874

873

872

871

870

869

868

867

866

865

864

863

862

861
Temp ( $\left.{ }^{\circ} \mathrm{F}\right)$

196.1

207.1

151.6

148.4

153.3

72.4

72.4

88.0

72.8

226.4

227.6

242.0

236.8

189.9

168.1

188.2

70.9

71.5

90.0

71.7

245.7

243.6

204.0

206.4

167.5

169.2

167.8

71.2

70.9

86.3

71.1
DRYWELL NO. 3

I $\angle \mathrm{C}$ No. $\quad$ Temp $\left({ }^{\circ} \mathrm{F}\right)$

854

853

852

851

850

849

848

847

846

845

844

843

842

841

840

839

838

837

8.36

835

834

833

832

831

830

829

828

827

826

825

824
194.4

204.8

145.4

142.0

146.9

69.8

69.6

86.0

69.8

216.9

223.7

234.7

237.3

180.9

181.5

180.3

70.6

70.7

91.3

70.6

246.2

243.2

205.0

205.2

166.1

169.6

165.9

71.0

71.4

87.4

71.1

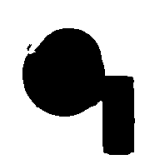


TABLE $\quad B-11$

ISOLATED DRYWELL TEST - THERMOCOUPLE DATA

DATE: $6 / 1 / 79$

OPERATING HOURS: DRYWELL NO. 5: 3366 DRYWELL NO. 3: 3053

\section{THERMOCOUPLE READINGS}

\begin{tabular}{|c|c|c|c|}
\hline \multicolumn{2}{|c|}{ DRYWELL NO. 5} & \multicolumn{2}{|c|}{ DRYWELL NO. 3} \\
\hline T/C No. & $\operatorname{Temp}\left({ }^{\circ} \mathrm{F}\right)$ & I/C No. & Temp $\left({ }^{\circ} \mathrm{F}\right)$ \\
\hline 891 & 200.2 & 854 & 198.6 \\
\hline 890 & 210.9 & 853 & 207.5 \\
\hline 889 & 161.6 & 852 & 153.9 \\
\hline 888 & 157.7 & 851 & 157.0 \\
\hline 887 & 164.8 & 850 & 153.9 \\
\hline 886 & 76.8 & 849 & 74.7 \\
\hline 885 & 77.3 & 848 & 74.2 \\
\hline 884 & 92.3 & 847 & 90.7 \\
\hline 883 & 77.9 & 846 & 74.6 \\
\hline 882 & 229.4 & 845 & 220.6 \\
\hline 887 & 231.8 & 844 & 226.3 \\
\hline 880 & 245.1 & 843 & 238.2 \\
\hline $\begin{array}{l}879 \\
878\end{array}$ & 240.6 & 842 & 240.2 \\
\hline $\begin{array}{l}878 \\
877\end{array}$ & $\begin{array}{l}195.0 \\
163.0\end{array}$ & 841 & 186.0 \\
\hline 876 & 194.5 & 839 & 186.0 \\
\hline 875 & 73.2 & 838 & 72.6 \\
\hline 874 & 73.4 & 837 & 73.0 \\
\hline 873 & 92.1 & 836 & 93.0 \\
\hline 872 & 73.6 & 835 & 72.8 \\
\hline 871 & 248.4 & 834 & 248.8 \\
\hline 870 & 246.1 & 833 & 245.9 \\
\hline $\begin{array}{l}869 \\
868\end{array}$ & 206.0 & 832 & 206.1 \\
\hline $\begin{array}{l}868 \\
867\end{array}$ & $\begin{array}{l}208.1 \\
162.1\end{array}$ & $\begin{array}{l}831 \\
830\end{array}$ & $\begin{array}{l}206.7 \\
759.3\end{array}$ \\
\hline 866 & 163.3 & 829 & 163.0 \\
\hline 865 & 163.0 & 828 & 161.5 \\
\hline 864 & 72.0 & 827 & 72.3 \\
\hline 863 & 72.1 & 826 & 72.4 \\
\hline 862 & 87.1 & 825 & 88.6 \\
\hline 861 & 72.2 & 824 & 72.0 \\
\hline
\end{tabular}


TABLE $\quad B-12$

ISOLATED DRYWELL TEST - THERMOCOUPLE DATA

DATE : $\quad 6 / 15 / 79$

OPERATING HOURS: DRYWELL NO. 5: 3702
TIME : $\quad 4: 00$ p.m.

DRYWELL NO. 3: 3389

\section{THERMOCOUPLE READINGS}

DRYWELL NO. 5

\begin{tabular}{cr} 
T/C No. & Temp $\left(^{\circ} \mathrm{F}\right)$ \\
\hline 891 & 203.1 \\
890 & 212.4 \\
889 & 164.5 \\
888 & 161.0 \\
887 & 167.4 \\
886 & 80.3 \\
885 & 80.8 \\
884 & 95.6 \\
883 & 81.5 \\
882 & 232.5 \\
881 & 233.8 \\
880 & 247.4 \\
879 & 242.8 \\
878 & 197.5 \\
877 & 164.8 \\
876 & 197.1 \\
875 & 75.2 \\
874 & 75.5 \\
873 & 93.9 \\
8732 & 75.9 \\
871 & 250.1 \\
870 & 248.0 \\
869 & 207.4 \\
868 & 209.6 \\
867 & 164.0 \\
866 & 165.2 \\
865 & 164.9 \\
864 & 73.1 \\
863 & 73.1 \\
862 & 88.2 \\
861 & 73.3
\end{tabular}

DRYWELL NO. 3

\begin{tabular}{cr} 
T/C No. & Temp ( $\left.{ }^{\circ} \mathrm{F}\right)$ \\
\hline & \\
854 & 200.9 \\
853 & 209.8 \\
852 & 156.4 \\
851 & 153.9 \\
850 & 156.6 \\
849 & 78.5 \\
848 & 78.0 \\
847 & 94.1 \\
846 & 78.4 \\
845 & 223.0 \\
844 & 229.0 \\
843 & 240.4 \\
842 & 242.6 \\
841 & 189.2 \\
840 & 189.7 \\
839 & 189.0 \\
838 & 75.0 \\
837 & 75.2 \\
836 & 95.1 \\
835 & 75.2 \\
834 & 250.6 \\
833 & 247.8 \\
832 & 207.7 \\
831 & 208.2 \\
830 & 161.4 \\
829 & 165.0 \\
828 & 163.4 \\
827 & 73.3 \\
826 & 73.5 \\
825 & 89.5 \\
824 & 73.2 \\
& \\
\hline &
\end{tabular}

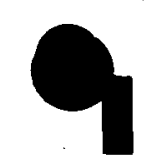


TABLE B-13

ISOLATED DRYWELL TEST - THERMOCOUPLE DATA

DATE : $\quad 7 / 1 / 79$

OPERATING HOURS: DRYWELL NO. 5: 4086
TIME: 4:00 p.m.

DRYWELL NO. 3: 3773

\section{THERMOCOUPLE READINGS}

\begin{tabular}{|c|c|c|c|}
\hline \multicolumn{2}{|c|}{ DRYWELL NO. 5} & \multicolumn{2}{|c|}{ DRYWELL NO. 3} \\
\hline I/C No. & $\operatorname{Temp}\left({ }^{\circ} \mathrm{F}\right)$ & I/C No. & Temp $\left({ }^{\circ} \mathrm{F}\right)$ \\
\hline 891 & 203.1 & 854 & $202.3^{\circ}$ \\
\hline 890 & 274.2 & 853 & 271.1 \\
\hline 889 & 166.1 & 852 & 158.8 \\
\hline 888 & 162.6 & 851 & 155.8 \\
\hline 887 & 169.6 & 850 & 158.6 \\
\hline 886 & 83.0 & 849. & 81.3 \\
\hline 885 & 83.3 & 848 & 80.9 \\
\hline 884 & 98.0 & 847 & 96.6 \\
\hline 883 & 84.0 & 846 & 80.4 \\
\hline 882 & 233.7 & 845 & 224.5 \\
\hline 881 & 235.1 & 844 & 230.5 \\
\hline 880 & 249.3 & 843 & 242.0 \\
\hline 879 & 244.0 & 842 & 244.2 \\
\hline 878 & 199.4 & 841 & 191.5 \\
\hline 877 & 166.5 & 840 & 192.5 \\
\hline 876 & 199.1 & 839 & 191.3 \\
\hline 875 & 77.4 & 838 & 77.6 \\
\hline 874. & 77.8 & 837 & 77.5 \\
\hline 873 & 95.7 & 836 & 97.2 \\
\hline 872 & 78.2 & 835 & 77.7 \\
\hline 871 & 251.3 & 834 & 252.2 \\
\hline 870 & 249.3 & 833 & 249.1 \\
\hline 869 & 208.3 & 832 & 208.8 \\
\hline 868 & 210.6 & 831 & 209.2 \\
\hline $\begin{array}{l}867 \\
866\end{array}$ & 165.6 & $\begin{array}{l}830 \\
829\end{array}$ & 163.4 \\
\hline 865 & 166.4 & 828 & 165.2 \\
\hline 864 & 74.3 & 827 & 74.6 \\
\hline 863 & 74.1 & 826 & 74.7 \\
\hline 862 & 89.2 & 825 & 90.5 \\
\hline 861 & 74.4 & 824 & 74.6 \\
\hline
\end{tabular}


TABLE $B-74$

ISOLATED DRYWELL TEST - THERMOCOUPLE DATA

DATE : $\quad 7 / 15 / 79$

OPERATING HOURS: DRYWELL NO. 5: 4422
TIME: 4:00 p.m.

DRYWELL NO. 3: 4109

\section{THERMOCOUPLE READINGS}

DRYWELL NO. 5

\begin{tabular}{cr} 
T/C No. & Temp $\left(^{\circ} \mathrm{F}\right)$ \\
\hline 891 & 204.3 \\
890 & 215.3 \\
889 & 167.8 \\
888 & 164.4 \\
887 & 171.4 \\
886 & 85.2 \\
885 & 85.3 \\
884 & 99.9 \\
883 & 86.1 \\
882 & 234.8 \\
881 & 235.8 \\
880 & 250.0 \\
879 & 245.1 \\
878 & 200.9 \\
877 & 168.0 \\
876 & 200.8 \\
875 & 79.3 \\
874 & 79.6 \\
873 & 97.2 \\
872 & 80.1 \\
871 & 252.1 \\
870 & 250.1 \\
869 & 209.1 \\
868 & 211.3 \\
867 & 167.1 \\
866 & 168.3 \\
865 & 168.0 \\
864 & 75.5 \\
863 & 75.3 \\
862 & 90.2 \\
861 & 75.6
\end{tabular}

DRYWELL NO. 3

I/C No. Temp ( $\left.{ }^{\circ} \mathrm{F}\right)$

854

853

852

851

850

849

848

847

846

845

844

843

842

841

840

839

838

837

836

835

834

833

832

831

830

829

828

827

826

825

824
203.7

212.3

160.4

157.6

160.4

83.8

83.3

96.7

83.7

226.0

231.6

243: 0

215.5

193.2

194.4

193.0

$79: 5$

79.4

98.7

79.6

252.8

250.0

209.4

209.9

164.8

168.1

166.8

75.7

76.0

91.6

75.8

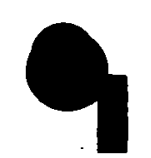


TABLE B-15

ISOLATED DRYWELL TEST - THERMOCOUPLE DATA

DATE : $\quad 8 / 1 / 79$

OPERATING HOURS: DRYWELL NO. 5: 4380
TIME: 4:00 p.m.

DRYWELL NO. 3: 4517

THERMOCOUPLE READINGS

\begin{tabular}{|c|c|c|c|}
\hline \multicolumn{2}{|c|}{ DRYWELL NU. 5} & \multicolumn{2}{|c|}{ DRYWELL NO. 3} \\
\hline I/C No. & $\operatorname{Temp}\left({ }^{\circ} \mathrm{F}\right)$ & I/C No. & Temp $\left({ }^{\circ} \mathrm{F}\right)$ \\
\hline 891 & 204.9 & 854 & 205.1 \\
\hline 890 & 216.1 & 853 & 213.4 \\
\hline 889 & 169.1 & 852 & 162.1 \\
\hline 888 & 165.9 & 851 & 159.4 \\
\hline 887 & 173.5 & 850 & 162.1 \\
\hline 886 & 88.2 & 849 & 86.8 \\
\hline 885 & 88.3 & 848 & 86.2 \\
\hline 884 & 102.6 & 847 & 101.3 \\
\hline 883 & 89.1 & 846 & 86.7 \\
\hline 882 & 235.5 & 845 & 226.8 \\
\hline 881 & 236.8 & 844 & 232.8 \\
\hline 880 & 250.9 & 843 & 244.2 \\
\hline 879 & 245.8 & 842 & 246.2 \\
\hline 878 & 202.4 & 841 & 195.0 \\
\hline 877 & 169.8 & 840 & 196.3 \\
\hline 876 & 202.3 & 839 & 194.8 \\
\hline 875 & 81.5 & 838 & 81.8 \\
\hline 874 & 81.7 & 837 & 81.7 \\
\hline 873 & 99.0 & 836 & 100.6 \\
\hline 872 & 82.3 & 835 & 81.9 \\
\hline 871 & 252.8 & 834 & 253.6 \\
\hline 870 & 250.8 & 833 & 250.7 \\
\hline 869 & 210.3 & 832 & 210.2 \\
\hline $\begin{array}{l}868 \\
867\end{array}$ & 212.5 & 831 & 210.8 \\
\hline 866 & $\begin{array}{l}169.7 \\
170.2\end{array}$ & $\begin{array}{l}830 \\
829\end{array}$ & $\begin{array}{l}166.1 \\
169.6\end{array}$ \\
\hline 865 & 169.9 & 828 & 168.3 \\
\hline 864 & 77.1 & 827 & 77.3 \\
\hline 863 & 77.0 & 826 & 77.5 \\
\hline 862 & 91.6 & 825 & 92.8 \\
\hline 861 & 77.2 & 824 & 77.3 \\
\hline
\end{tabular}


TABLE B-16

ISOLATED DRYWELL TEST - THERMOCOUPLE DATA

DATE : $\quad 8 / 15 / 79$

OPERATING HOURS: ORYWELL NO. 5: 5166
TIME: 4:00 p.m.

DRYWELL NO. 3: 4853

\section{THERMOCOUPLE READINGS}

DRYWELL NO. 5

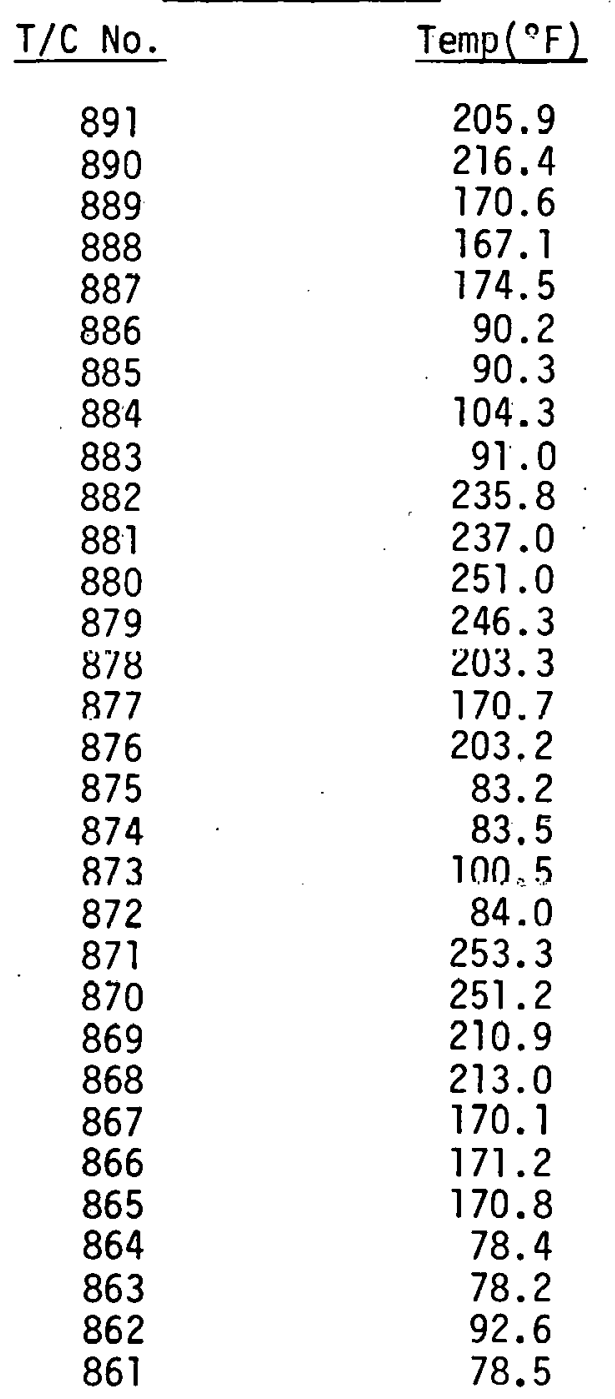

DRYWELL NO. 3.

\begin{tabular}{cr} 
T/C No. & Temp $\left({ }^{\circ} \mathrm{F}\right)$ \\
\hline 854 & 204.6 \\
853 & 213.9 \\
852 & 162.9 \\
851 & 159.9 \\
850 & 162.9 \\
849 & 88.7 \\
848 & 88.2 \\
847 & 103.0 \\
846 & 88.6 \\
845 & 227.5 \\
844 & 233.2 \\
843 & 244.9 \\
842 & 247.0 \\
841 & 196.2 \\
840 & 197.7 \\
839 & 196.2 \\
838 & 83.6 \\
837 & 83.4 \\
836 & 102.0 \\
835 & 83.7 \\
834 & 254.2 \\
833 & 251.4 \\
832 & 210.8 \\
831 & 211.3 \\
830 & 167.1 \\
829 & 170.4 \\
828 & 170.3 \\
827 & 78.6 \\
826 & 78.7 \\
825 & 93.8 \\
824 & 78.6 \\
&
\end{tabular}

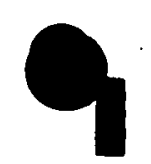


TABLE $\quad B-17$

ISOLATED DRYWELL TEST - THERMOCOUPLE DATA

DATE : $9 / 1 / 79$

OPERATING HOURS: DRYWELL NO. 5: 5574 DRYWELL NO. 3: 5261
TIME: 4:00 p.m.

THERMOCOUPLE READINGS

DRYWELL NO. 5

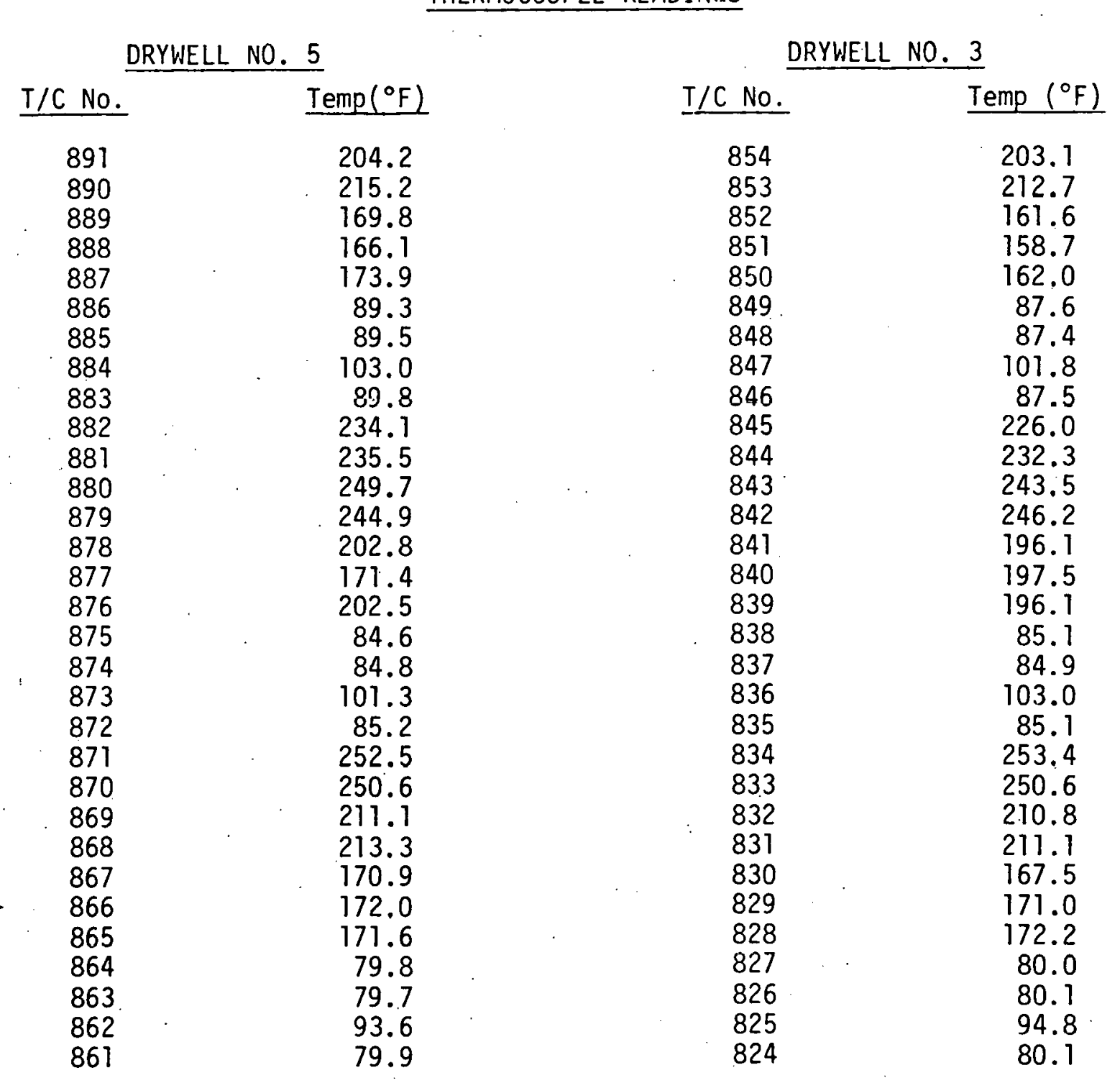




$$
\text { TABLE B-18 }
$$

ISOLATED DRYWELL TEST - THERMOCOUPLE DATA

DATE : $\quad 9 / 15 / 79$

OPERATING HOURS: DRYWELL NO. 5: 5910 DRYWELL NO. 3: 5597
TIME: 4:00 p.m.

\section{THERMOCOUPLE READINGS}

DRYWELL NO. 5

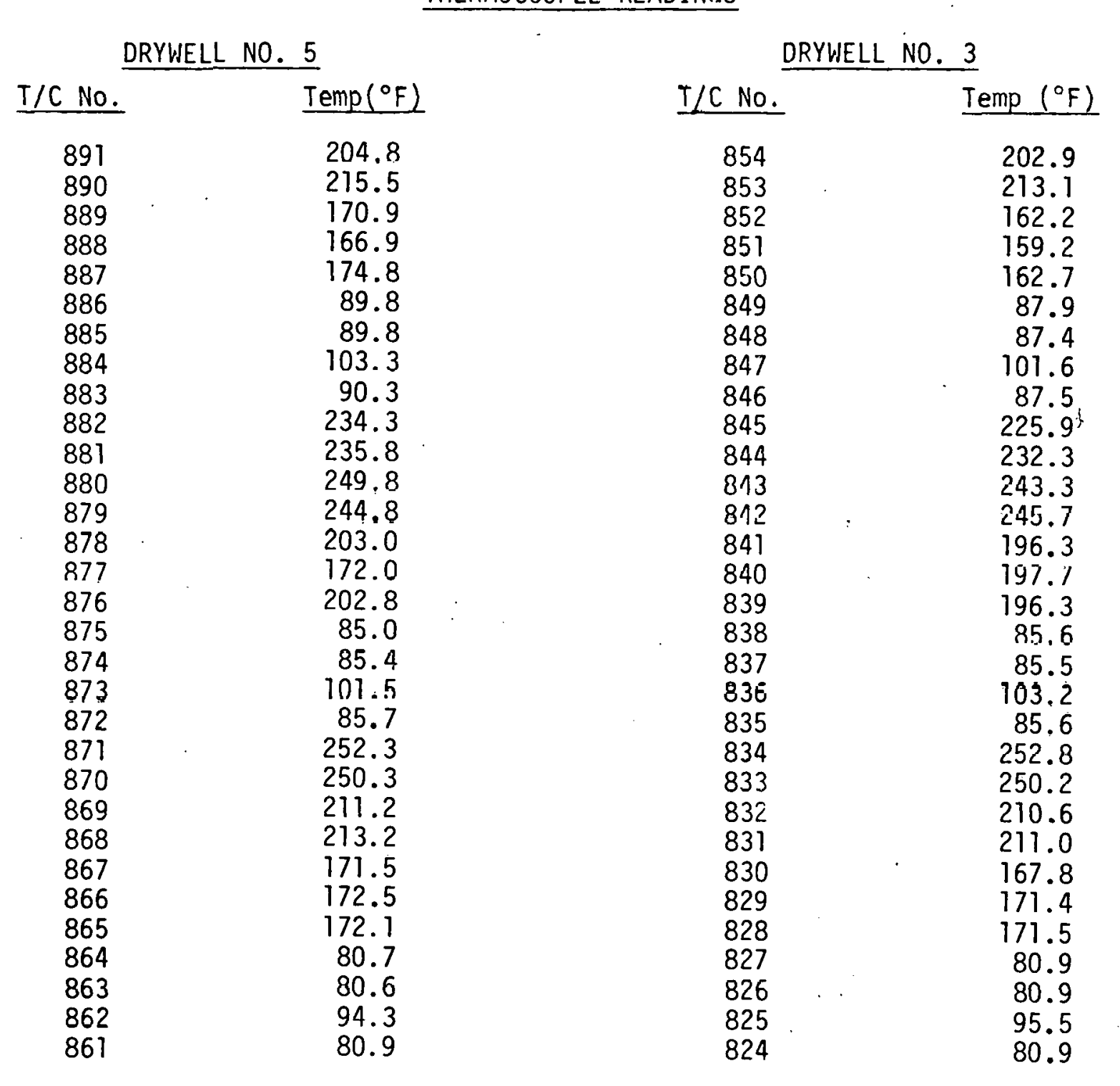

\section{9}


TABLE B-19

ISOLATED DRYWELL TEST - THERMOCOUPLE DATA

DATE: $\quad 10 / 1 / 79$

OPERATING HOURS: DRYWELL NO. 5: 6294
TIME : $\quad 4: 00$ p.m.

DRYWELL NO. 3: $\quad 5981$

\section{THERMOCOUPLE READINGS}

DRYWELL NO. 5

\begin{tabular}{cr} 
T/C No. & Temp $\left({ }^{\circ} \mathrm{F}\right)$ \\
\hline 891 & 203.3 \\
890 & 214.2 \\
889 & 170.5 \\
888 & 165.9 \\
887 & 174.5 \\
886 & 90.0 \\
885 & 90.4 \\
884 & 103.3 \\
883 & 90.7 \\
882 & 233.6 \\
881 & 234.5 \\
880 & 248.7 \\
879 & 243.7 \\
878 & 202.3 \\
877 & 172.0 \\
876 & 202.0 \\
875 & 85.8 \\
874 & 85.8 \\
873 & 101.9 \\
872 & 86.2 \\
871 & 251.6 \\
870 & 249.4 \\
869 & 210.9 \\
868 & 212.8 \\
867 & 171.5 \\
866 & 172.4 \\
865 & 172.2 \\
864 & 81.3 \\
863 & 81.2 \\
862 & 94.5 \\
861 & 81.5
\end{tabular}

DRYWELL NO. 3

\begin{tabular}{cr} 
T/C No. & Temp $\left({ }^{\circ} \mathrm{F}\right)$ \\
\hline & 201.1 \\
854 & 212.3 \\
853 & 161.1 \\
852 & 158.2 \\
851 & 162.2 \\
850 & 87.7 \\
849 & 87.4 \\
848 & 101.4 \\
847 & 87.4 \\
846 & 224.8 \\
845 & 231.2 \\
844 & 242.3 \\
843 & 244.7 \\
842 & 195.9 \\
841 & 197.1 \\
840 & 196.4 \\
839 & 86.3 \\
838 & 86.2 \\
837 & 103.3 \\
836 & 86.3 \\
835 & 252.2 \\
834 & 249.8 \\
833 & 210.4 \\
832 & 210.7 \\
831 & 167.6 \\
830 & 171.4 \\
829 & 170.7 \\
828 & 81.7 \\
827 & 81.6 \\
826 & 95.9 \\
825 & 81.4 \\
824 &
\end{tabular}


TABLE B-20

\section{ISOLATED DRYWELL TEST - THERMOCOUPLE DATA}

DATE : $10 / 15 / 79$

OPERATING HOURS: DRYWELL NO. 5: 6630
TIME : $\quad 4: 00$ p.m,

DRYWELL NO. 3: 6317

\section{THERMOCOUPLE READINGS}

DRYWELL NO. 5

I/C No.

891

890

889

888

887

886

885

884

883

882

881

880

879

878

877

876

875

874

873

872

871

870

869

868

867

866

865

864

863

862

861
$\operatorname{Temp}\left({ }^{\circ} \mathrm{F}\right)$

203.1

213.6

169.7

164.7

173.5

88.7

89.2

101.9

89.4

231.2

233.2

246.9

242.6

201.6

172.3

201.3

86.2

86.3

102.1

86.5

250.7

248.6

210.8

212.6

171.6

172.7

172.4

82.1

82.0

95.2

82.3
DRYWELL NO. 3

I/C No. . Temp $\left({ }^{\circ} \mathrm{F}\right)$

854

853

852

851

850

849

848

847

846

845

844

843

842

841

840

839

838

837

836

835

834

833

832

831

830

829

828

827

826

825

824
200.3

211.1

160.5

157.6

161.6

86.5

86,5

100.2

86.5

223.7

230.1

241.0

243.9

$\lceil 95.5$

196.5

195.7

86.2

86.3

103., 1

86.4

251.0

248.6

209.7

210.0

167.2

171.5

170.6

82.5

82.3

96.4

82.2

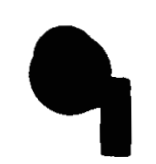


TABLE B-21

ISOLATED DRYWELL TEST - THERMOCOUPLE DATA

DATE : $\quad 11 / 1 / 79$

OPERATING HOURS:- DRYWELL NO: 5: 7038
TIME : 4:00 p.m.

DRYWELL NO. 3: 6725

\section{THERMOCOUPLE READINGS}

DRYWELL NO. 5

\begin{tabular}{cr} 
T/C No. & Temp $\left({ }^{\circ} \mathrm{F}\right)$ \\
\cline { 2 - 2 } 891 & 200.1 \\
890 & 210.3 \\
889 & 166.3 \\
888 & 161.2 \\
887 & 169.9 \\
886 & 84.7 \\
885 & 85.5 \\
884 & 97.7 \\
883 & 85.4 \\
882 & 227.3 \\
881 & 229.6 \\
880 & 243.6 \\
879 & 239.5 \\
878 & 199.1 \\
877 & 171.7 \\
876 & 198.8 \\
875 & 85.3 \\
874 & 85.4 \\
873 & 100.9 \\
872 & 85.7 \\
871 & 248.7 \\
870 & 246.6 \\
869 & 209.9 \\
868 & 211.6 \\
867 & 170.9 \\
866 & 171.9 \\
865 & 171.6 \\
864 & 81.9 \\
863 & 81.8 \\
862 & 94.8 \\
861 & 82.1 \\
&
\end{tabular}

DRYWELL NO. 3

T/C No. Temp ( $\left.{ }^{\circ} \mathrm{F}\right)$

854

853

852

851

850

849 .

848

847

846

845

844

843

842 .

841

840

839

838

837

836

835

834

833

832

831

830

829

828

827

826

825

824
195.8

208.5

156.6

153.7

158.9

82.6

83.1

96.3

82.7

220.1

227.1

238.1

241.5

193.2

194.5

193.4

85.0

85.1

101.6

85.2

248.5

246.4

208.6

208.8

166.2

170.7

173.9

82.3

82.1

96.0

82.2 
TABLE $\quad B-22$

ISOLATED DRYWELL TEST - THERMOCOUPLE DATA

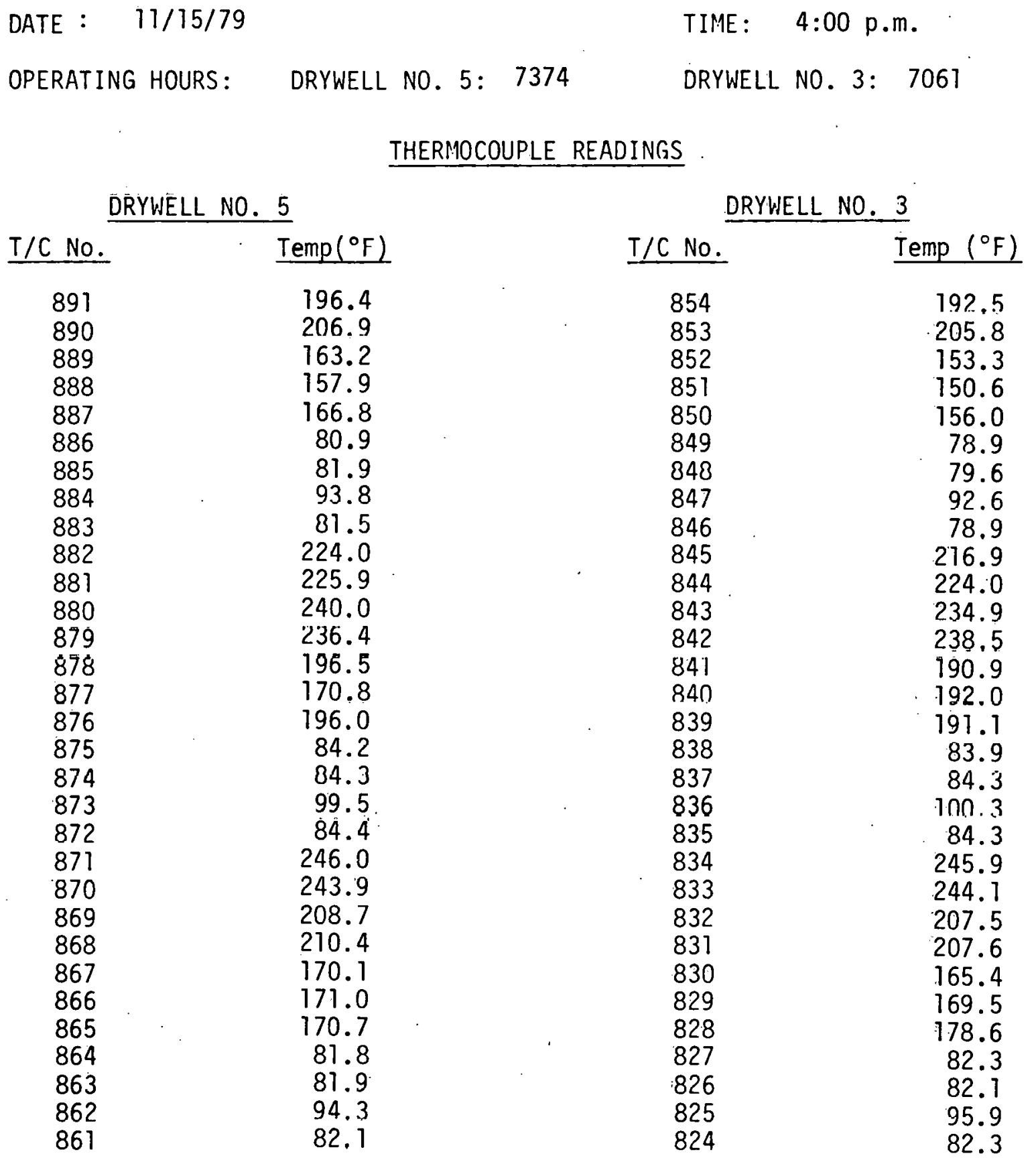

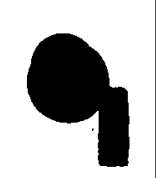


TABLE $\quad B-23$

ISOLATED DRYWELL TEST - THERMOCOUPLE DATA

DATE: $\quad 12 / 1 / 79$

TIME: $4: 00$ p.m.

OPERATING HOURS: DRYWELL NO. 5: 7758 DRYWELL NO. 3: 7445

THERMOCOUPLE READINGS

URYWELL NO. 5

\section{T/C No.}

891

890

889

888

887

886

885

884

883

882

881

880

879

878

877

876

875

874

873

872

871

870

869

868

867

866

865

864

863

862

861

\section{Temp $\left({ }^{\circ} \mathrm{F}\right)$}

193.0

203.0

159.9

154.6

163.2

76.9

78.0

89.7

77.4

220.0

222.2

236.2

232.7

193.3

169.3

192.7

82.5

82.7

97.5

82.8

243.1

247.1

207.1

208.8

168.8

169.9

169.2

81.9

81.7

94.1

82.1
DRYWELL NO. 3

T/C NO.

854

853

852

851

850

849

848

847

846

845

844

843

842

841

840

839

838

837

836

835

834

833

832

831

830

829

828

827

826

825

824
Temp $\left({ }^{\circ} \mathrm{F}\right)$

189.3

202.2

150.0

147.1

152.4

74.6

75.7

88.3

74.7

212.9

220.4

231.3

234.7

187.8

189.0

188.0

82.4

82.6

98.5

82.6

242.9

241.0

205.9

205.8

164.1

168.0

176.2

81.9

82.0

95.2

82.0 
TABLE B-24

ISOLATED DRYWELL TEST - THERMOCOUPLE DATA

DATE : $\quad 12 / 15 / 79$

OPERATING HOURS: DRYWELL NO. 5: 8094
TIME: $\quad 4: 00$ p.m.

DRYWELL NO. 3: 7781

\section{THERMOCOUPLE READINGS}

\begin{tabular}{|c|c|c|c|}
\hline \multicolumn{2}{|c|}{ DRYWELL NO. 5} & \multicolumn{2}{|c|}{ DRYWELL NO. 3} \\
\hline T/C No. & $\operatorname{Temp}\left({ }^{\circ} \mathrm{F}\right)$ & T/C No. & Temp $\left({ }^{\circ} \mathrm{F}\right)$ \\
\hline 891 & 191.1 & 854 & 186.8 \\
\hline 890 & 201.0 & 853 & 200.4 \\
\hline 889 & 158.0 & 852 & 147.6 \\
\hline 888 & 152.7 & 851 & 144.9 \\
\hline 887 & 161.2 & 850 & 150.6 \\
\hline 886 & 74.3 & 849 & 71.9 \\
\hline 885 & 75.4 & 848 & 73.0 \\
\hline 884 & 87.3 & 847 & 85.7 \\
\hline 883 & 7.4 .9 & 846 & 72.1 \\
\hline 882 & 217.6 & 845 & 210.3 \\
\hline 881 & 219.8 & $844^{\circ}$ & 278.3 \\
\hline 880 & 234.0 & 843 & 228.7 \\
\hline $8 / 9$ & 229.8 & 842 & 232.8 \\
\hline 878 & 190.8 & 841 & 185.6 \\
\hline 877 & 168.0 & 840 & 186.9 \\
\hline 876 & 190.2 & 839 & $185: 9$ \\
\hline 875 & 80.6 & 838 & 80.5 \\
\hline $\begin{array}{l}874 \\
873\end{array}$ & 80.9 & 837 & 80.8 \\
\hline $\begin{array}{l}873 \\
872\end{array}$ & $\begin{array}{l}95.5 \\
80.9\end{array}$ & $\begin{array}{l}836 \\
835\end{array}$ & 96.5 \\
\hline 871 & 240.8 & $\begin{array}{l}835 \\
834\end{array}$ & 240.7 \\
\hline 870 & 238.8 & 833 & 238.8 \\
\hline 869 & 205.2 & 832 & 204.4 \\
\hline 868 & 207.0 & 831 & 204.2 \\
\hline 867 & 167.1 & 830 & 162.9 \\
\hline 866 & 168.3 & 829 & 166.5 \\
\hline 865 & 167.6 & 828 & 17.3 .7 \\
\hline 864 & 80.9 & 827 & 81.2 \\
\hline 863 & $\begin{array}{l}80.8 \\
90.9\end{array}$ & 826 & 81.4 \\
\hline 861 & $\begin{array}{l}92.9 \\
81.2\end{array}$ & $\begin{array}{l}825 \\
824\end{array}$ & $\begin{array}{l}94.3 \\
81.4\end{array}$ \\
\hline
\end{tabular}

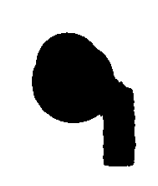




\section{TABLE B-25 \\ ISOLATED DRYWELL TEST - THERMOCOUPLE DATA}

DATE: $\quad 1 / 1 / 80$

OPERATING HOURS: DRYWELL NO. 5: 8502
TIME: 4:00 p.m.

DRYWELL NO. 3: 8189

\section{THERMOCOUPLE READINGS}

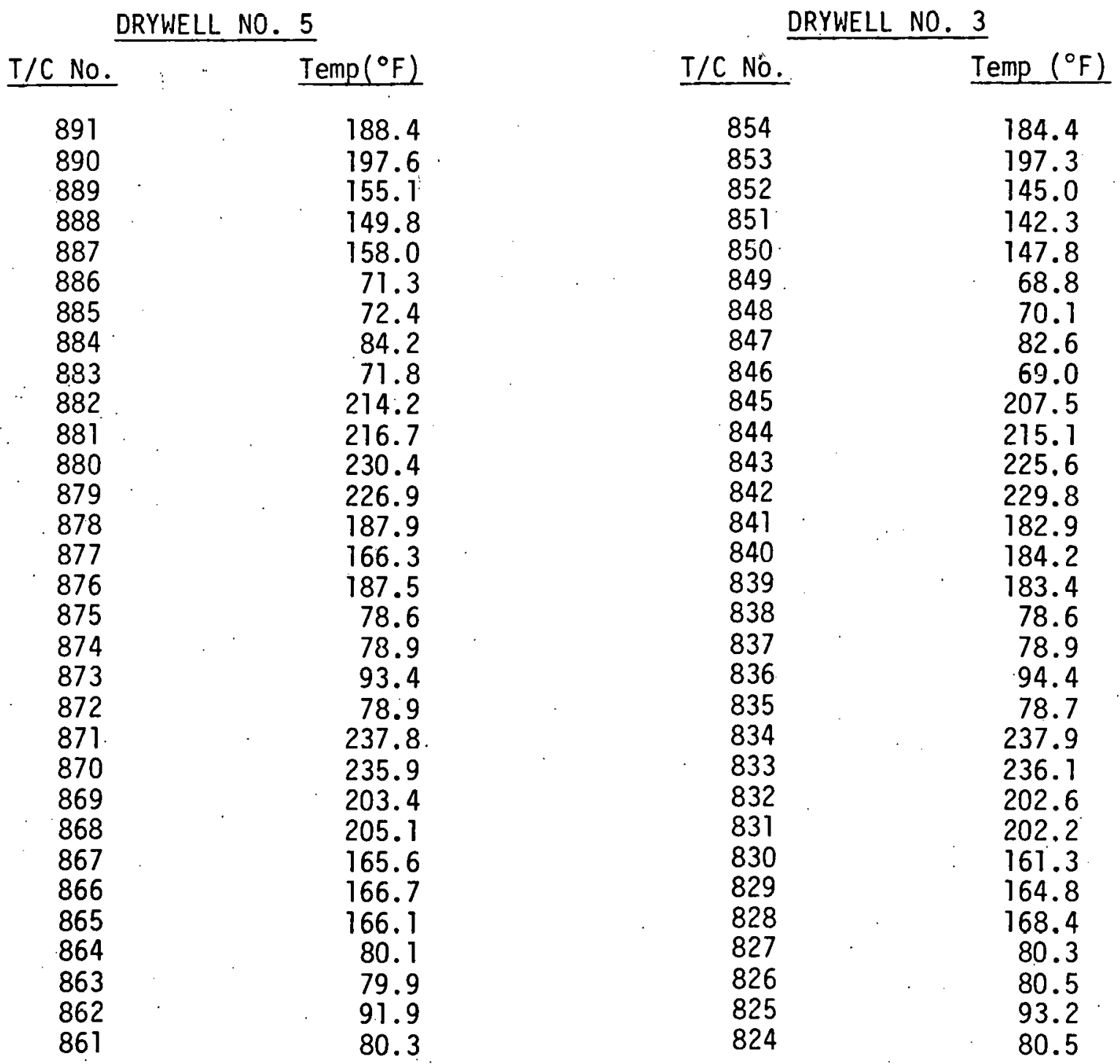


TABLE B-26

ISOLATED DRYWELL TEST - THERMOCOUPLE DATA

DATE : $\quad 1 / 15 / 80$

OPERATING HOURS: DRYWELL NO. 5: 8838
TIME : 4:00 p.m.

DRYWELL NO. 3: 8525

\section{THERMOCOUPLE READINGS}

\begin{tabular}{|c|c|c|c|}
\hline \multicolumn{2}{|c|}{ DRYWELL N0. 5} & \multicolumn{2}{|c|}{ DRYWELL NO. 3} \\
\hline T/C No. & $\operatorname{Temp}\left({ }^{\circ} \mathrm{F}\right)$ & I/C No. & Temp $\left({ }^{\circ} \mathrm{F}\right)$ \\
\hline 891 & 185.4 & 854 & 183.2 \\
\hline 890 & 195.6 & 853 & 195.4 \\
\hline 889 & 152.1 & 852 & 143.3 \\
\hline 888 & 147.7 & 851 & 141.0 \\
\hline 887 & 156.1 & 850 & 145.8 \\
\hline 886 & 69.2 & 849 & 66.7 \\
\hline 885 & 70.3 & 848 & 67.9 \\
\hline 884 & 82.0 & 847 & 80.5 \\
\hline 883 & 69.6 & 846 & 66.9 \\
\hline 882 & 272.4 & 845 & 205.9 \\
\hline 881 & 214.1 & 844 & 213.7 \\
\hline 880 & 228.3 & 843 & 223.7 \\
\hline 879 & 224.9 & 842 & 228.0 \\
\hline 878 & 186.0 & 841 & 181.2 \\
\hline 877 & 164.9 & 840 & 182.4 \\
\hline 876 & 185.4 & 839 & 181.8 \\
\hline 875 & 77.0 & 838 & 76.8 \\
\hline 874 & 77.3 & 837 & 77.3 \\
\hline 873 & 91.7 & 836 & 92.6 \\
\hline 872 & 77.3 & 835 & 77.1 \\
\hline 871 & 235.7 & 834. & 235.8 \\
\hline $\begin{array}{l}870 \\
869\end{array}$ & $\begin{array}{r}233.9 \\
201\end{array}$ & $\begin{array}{l}833 \\
823\end{array}$ & 234.1 \\
\hline $\begin{array}{l}809 \\
868\end{array}$ & 203.4 & $\begin{array}{l}832 \\
831\end{array}$ & 200.8 \\
\hline 867 & 164.9 & 830 & 159.9 \\
\hline 866 & 165.3 & 829 & 163.5 \\
\hline 865 & 164.7 & 828 & 175.0 \\
\hline $\begin{array}{l}864 \\
863\end{array}$ & 79.1 & 827 & $\begin{array}{r}79.5 \\
.70\end{array}$ \\
\hline $86 ?$ & 90.8 & 825 & 92.1 \\
\hline 861 & 79.3 & 824 & 79.7 \\
\hline
\end{tabular}


TABLE $\quad B-27$

ISOLATED DRYWELL TEST - THERMOCOUPLE DATA

DATE: $\quad 2 / 1 / 80$

OPERATING HOURS: ORYWELL NO. 5: 9246
TIME: 4:00 p.m.

DRYWELL NO. 3: 8933

\section{THERMOCOUPLE READINGS}

DRYWELL NO. 5

T/C No.

891

890

889

888

887

886

885

884

883

882

881

880

879

878

877

876

875

874

873

872

871

870

869

868

867

866

865

864

863

862

861
$\operatorname{Temp}\left({ }^{\circ} \mathrm{F}\right)$

182.7

193.2

149.6

145.3

753.7

67.5

68.2

80.3

67.9

209.4

211.3

225.3

221.8

183.3

163.2

182.9

75.1

75.5

89.7

75.5

232.9

237.3

199.7

201.3

163.0

163.6

162.9

78.0

77.9

89.7

78.1
DRYWELL NO. 3

I/C No.

854

853

852

851

850

849

848

847

846

845

844

843

842

841

840

839

838

837

836

835

834

833

832

831

830

829

828

827

826

825

824
Temp ( $\left.{ }^{\circ} \mathrm{F}\right)$

180.3

193.0

141.3

138.9

143.7

65.1

66.1

78.6

65.2

203.0

210.8

221.0

225.1

178.9

180.2

179.5

75.1

75.4

90.8

75.2

232.9

231.3

198.8

198.5

158.0

161.7

164.3

78.1

78.5

91.0

78.5 
TABLE B-28

ISOLATED DRYWELL TEST - THERMOCOUPLE DATA

DATE : $\quad 2 / 15 / 80$

TIME: $\quad 4: 00 \mathrm{p.m}$.

OPERATING HOURS: DRYWELL NO. 5: 9582 DRYWELL NO. 3: 9269

\section{THERMOCOUPLE READINGS}

DRYWELL NO. 5

\begin{tabular}{cr} 
T/C No. & Temp $\left(^{\circ} \mathrm{F}\right)$ \\
\hline 891 & 182.0 \\
890 & 192.1 \\
889 & 148.2 \\
888 & 144.3 \\
887 & 152.1 \\
886 & 67.0 \\
885 & 67.5 \\
884 & 79.7 \\
883 & 67.3 \\
882 & 208.0 \\
881 & 210.2 \\
880 & 224.0 \\
879 & 220.4 \\
878 & 182.0 \\
877 & 162.0 \\
876 & 181.5 \\
875 & 73.9 \\
874 & 74.3 \\
873 & 88.5 \\
872 & 74.3 \\
871 & 231.5 \\
870 & 229.8 \\
869 & 198.5 \\
868 & 200.1 \\
867 & 160.9 \\
866 & 162.5 \\
865 & 161.8 \\
864 & 77.2 \\
863 & 77.0 \\
862 & 88.7 \\
861 & 77.3
\end{tabular}

DRYWELL NO. 3

\begin{tabular}{cr} 
T/C No. & Temp $\left(^{\circ} \mathrm{F}\right)$ \\
\cline { 2 - 2 } 854 & 179.4 \\
853 & 192.1 \\
852 & 140.4 \\
851 & 138.0 \\
850 & 142.8 \\
849 & 64.6 \\
848 & 65.5 \\
847 & 78.0 \\
846 & 64.8 \\
845 & 201.7 \\
844 & 209.5 \\
843 & 219.7 \\
812 & 223.8 \\
841 & 177.8 \\
840 & 179.1 \\
839 & 178.1 \\
838 & 73.7 \\
837 & 74.0 \\
836 & 89.4 \\
835 & 73.8 \\
834 & 231.5 \\
833 & 229.8 \\
832 & 197.4 \\
831 & 197.1 \\
830 & 156.9 \\
829 & 160.5 \\
828 & 77.3 \\
827 & 77.7 \\
826 & 90.7 \\
825 & 77.7 \\
824 &
\end{tabular}




\section{TABLE $\quad B-29$}

\section{ISOLATED DRYWELL TEST - THERMOCOUPLE DATA}

DATE: $\quad 3 / 1 / 80$

OPERATING HOURS: DRYWELL NO. 5: 9942
TIME: 4:00 p.m.

DRYWELL NO. 3: 9629

\section{THERMOCOUPLE READINGS}

DRYWELL NO. 5

\begin{tabular}{cr} 
T/C No. & Temp $\left(^{\circ} \mathrm{F}\right)$ \\
\cline { 2 - 2 } 891 & 180.6 \\
890 & 190.5 \\
889 & 146.9 \\
888 & 142.9 \\
887 & 151.2 \\
886 & 66.5 \\
885 & 66.9 \\
884 & 79.1 \\
883 & 66.8 \\
882 & 206.4 \\
881 & 208.2 \\
880 & 222.1 \\
879 & 218.5 \\
878 & 179.8 \\
877 & 160.8 \\
876 & 179.6 \\
875 & 73.1 \\
874 & 73.4 \\
873 & 87.8 \\
872 & 73.5 \\
871 & 229.4 \\
870 & 227.8 \\
869 & 197.0 \\
868 & 198.5 \\
867 & 156.3 \\
866 & 161.2 \\
865 & 160.7 \\
864 & 76.6 \\
863 & 76.4 \\
862 & 88.1 \\
861 & 76.6
\end{tabular}

DRYWELL NO. 3

\begin{tabular}{cr} 
T/C No. & Temp $\left({ }^{\circ} \mathrm{F}\right)$ \\
\hline 854 & 179.6 \\
853 & 190.1 \\
852 & 140.1 \\
851 & 137.7 \\
850 & 141.0 \\
849. & 64.1 \\
848 & 64.8 \\
847 & 77.3 \\
846 & 64.2 \\
845 & 201.4 \\
844 & 207.9 \\
843 & 218.8 \\
842 & 222.5 \\
841 & 176.8 \\
840 & 178.0 \\
839 & 177.2 \\
838 & 72.8 \\
837 & 73.2 \\
836 & 88.4 \\
835 & 73.0 \\
834 & 230.1 \\
833 & 228.3 \\
832 & 195.8 \\
831 & 195.7 \\
830 & 155.7 \\
829 & 159.5 \\
828 & \\
827 & 76.6 \\
826 & 77.0 \\
825 & 89.4 \\
824 & 77.0
\end{tabular}


TABLE B-30

ISOLATED DRYWELL TEST - THERMOCOUPLE DATA

DATE: $\quad 3 / 15 / 80$

TIME: $4: 00$ p.m.

OPERATING HOURS: DRYWELL NO. 5: 10,278 DRYWELL NO. 3: 9,965

THERMOCOUPLE READINGS

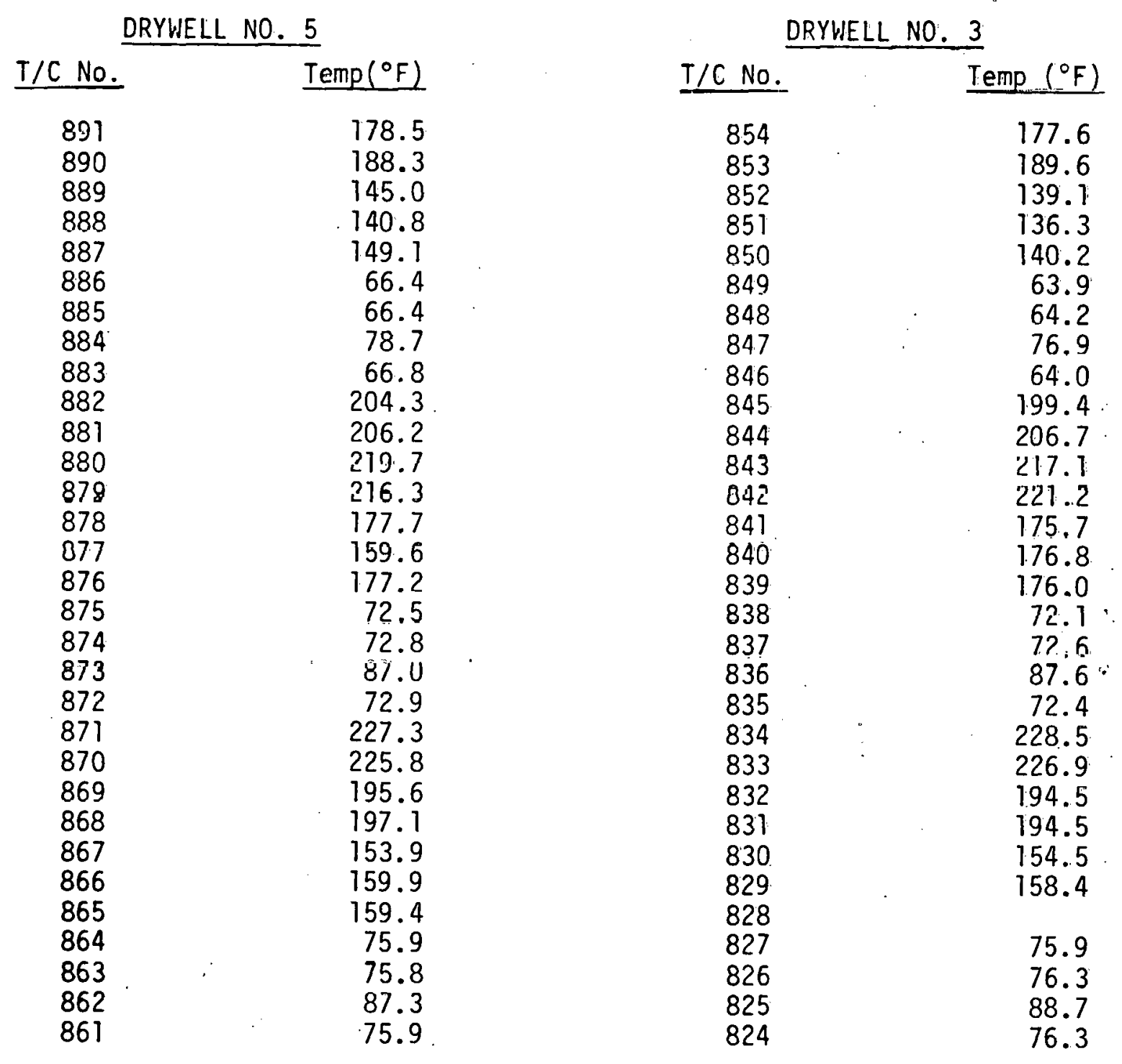


TABLE $\quad B-31$

ISOLATED DRYWELL TEST - THERMOCOUPLE DATA

DATE : $\quad 4 / 1 / 80$

OPERATING HOURS: DRYWELL NO. 5: 10,686
TIME: 4:00 p.m.

DRYWELL NO. 3: 10,373

\section{THERMOCOUPLE READINGS}

DRYWELL NO. 5

\begin{tabular}{cr} 
T/C No. & Temp $\left.{ }^{\circ} \mathrm{F}\right)$ \\
\hline 891 & 178.5 \\
890 & 188.3 \\
889 & 145.6 \\
888 & 141.4 \\
887 & 149.6 \\
886 & 66.8 \\
885 & 66.9 \\
884 & 78.9 \\
883 & 67.1 \\
882 & 204.4 \\
881 & 206.0 \\
880 & 219.7 \\
879 & 215.9 \\
878 & 177.6 \\
877 & 158.5 \\
876 & 177.3 \\
875 & 71.8 \\
874 & 72.0 \\
873 & 86.1 \\
872 & 72.2 \\
871 & 226.6 \\
870 & 225.1 \\
869 & 194.6 \\
868 & 196.2 \\
867 & 153.3 \\
866 & 159.2 \\
865 & 158.6 \\
864 & 75.2 \\
863 & 75.1 \\
862 & 86.6 \\
861 & 75.3
\end{tabular}

DRYWELL NO. 3

\begin{tabular}{cr} 
T/C No. & Temp $\left({ }^{\circ} \mathrm{F}\right)$ \\
\hline 854 & 176.3 \\
853 & 187.7 \\
852 & 137.7 \\
851 & 134.8 \\
850 & 138.1 \\
849 & 63.9 \\
848 & 64.3 \\
847 & 76.6 \\
846 & 64.1 \\
845 & 198.0 \\
844 & 205.0 \\
843 & 215.5 \\
842 & 219.1 \\
841 & 174.4 \\
840 & 175.6 \\
839 & 174.5 \\
838 & 71.5 \\
837 & 71.6 \\
836 & 86.8 \\
835 & 71.6 \\
834 & 226.9 \\
833 & 225.1 \\
832 & 193.3 \\
831 & 193.1 \\
830 & 153.5 \\
829 & 157.1 \\
828 & 75.1 \\
827 & 75.5 \\
826 & 87.7 \\
825 & 75.5 \\
824 &
\end{tabular}


TABLE B-32

ISOLATED DRYWELL TEST - THERMOCOUPLE DATA

DATE : $\quad 4 / 15 / 80$

OPERATING HOURS: DRYWELL NO. 5: 11,022. DRYWELL NO. 3: 10,709
TIME: 4:00 p.m.

\section{THERMOCOUPLE READINGS}

DRYWELL NO. 5

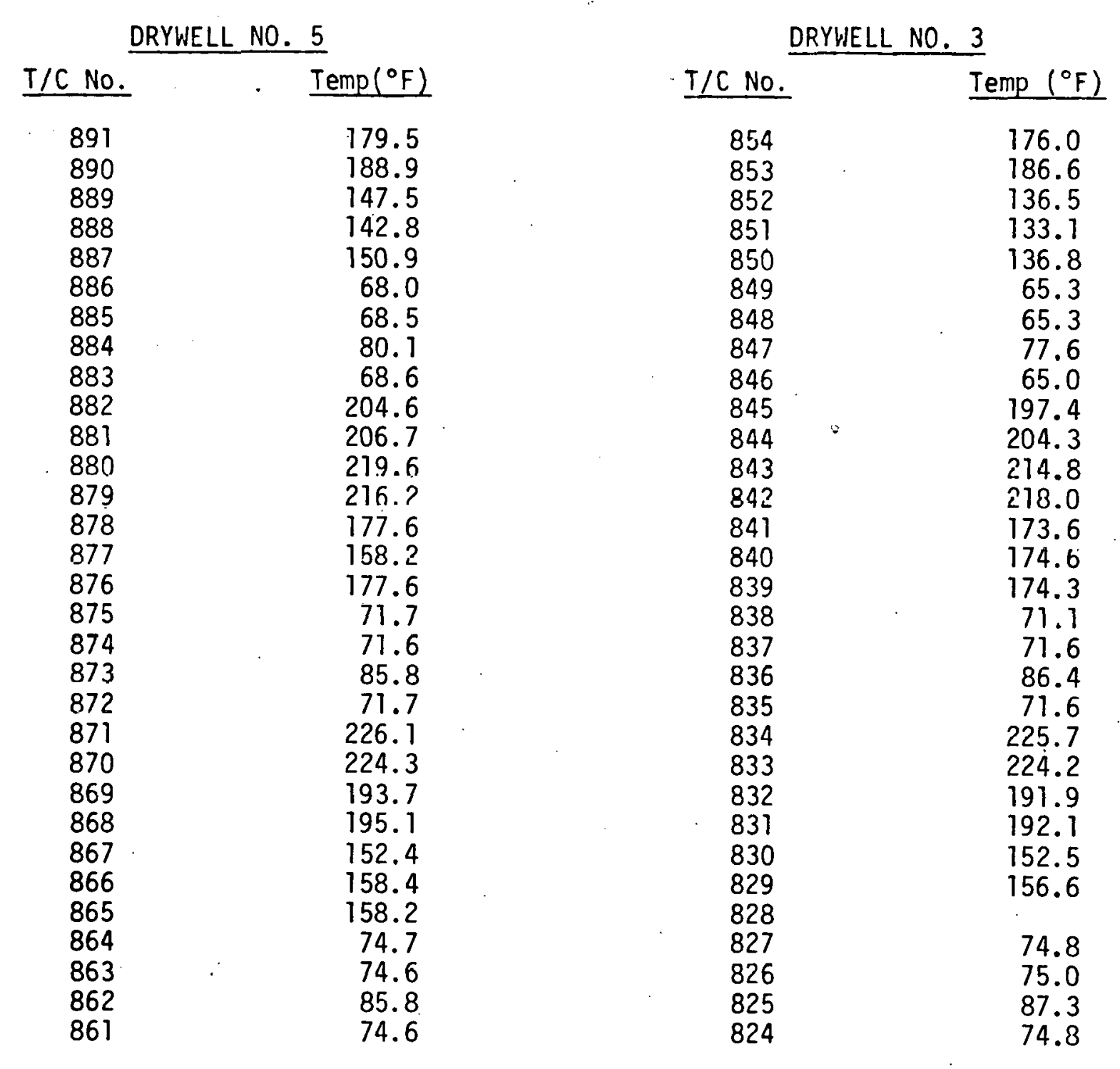

\section{THERMCOUPLE READINGS}




\section{TABLE B-33}

\section{ISOLATED DRYWELL TEST - THERMOCOUPLE DATA}

DATE : $\quad 5 / 1 / 80$

TIME: 4:00 p.m.

OPERATING HOURS: DRYWELL NO: 5: 11,406 DRYWELL NO. 3: 11,093

THERMOCOUPLE READINGS

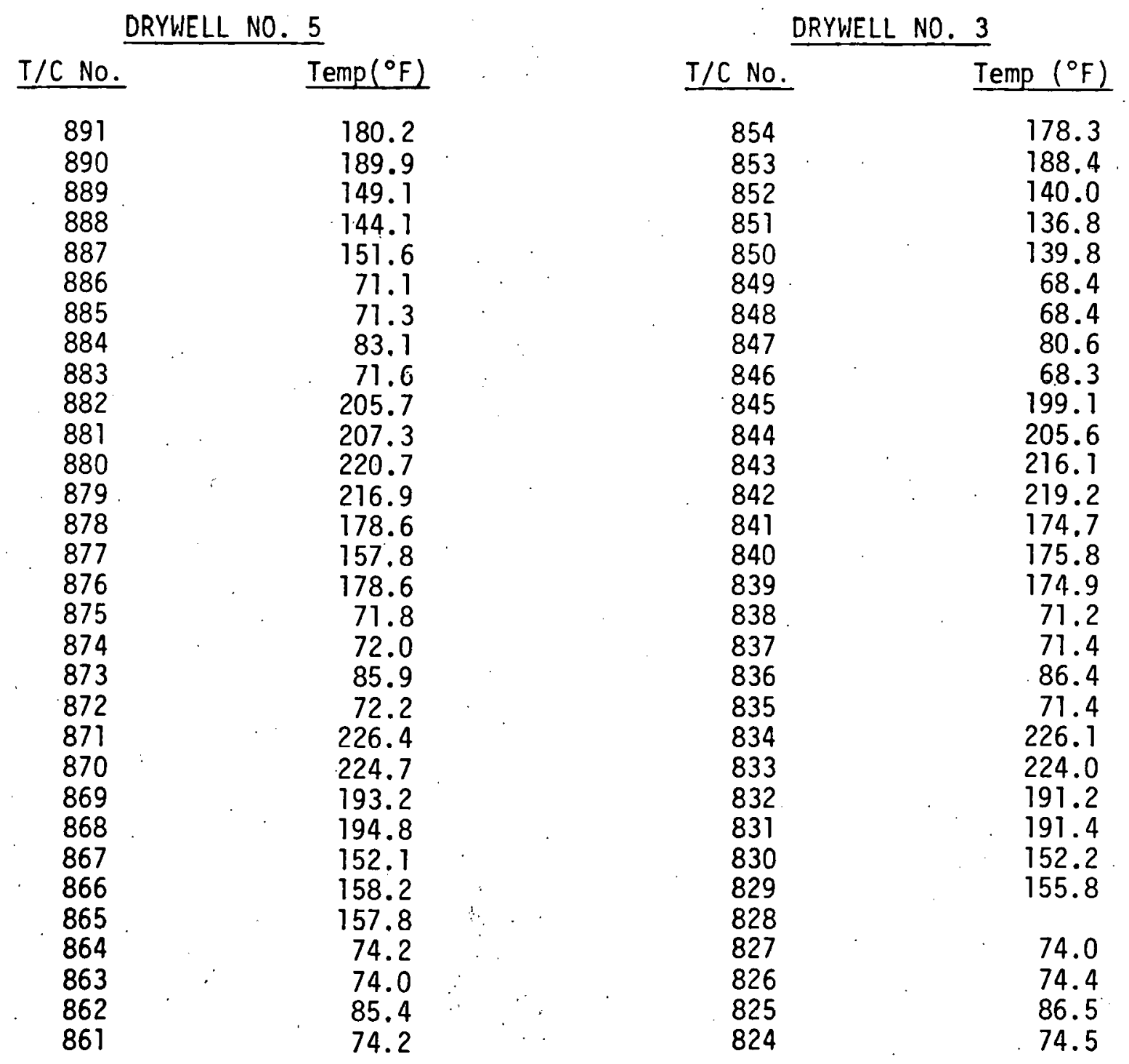


TABLE B-34.

ISOLATED DRYWELL TEST - THERMOCOUPLE DATA

DATE : $5 / 14 / 80$

OPERATING HOURS: DRYWELL NO. 5: 11,718 DRYWELL NO. 3: 11,405
TIME: 4:00 p.m.

\section{THERMOCOUPLE READINGS}

DRYWELL NO. 5

\section{T/C No.}

891

890

889

888

887

886

885

884

883

882

881

880

879

878

877

876

875

874

873

872

871

870

869

868

867

866

865

864

863

862

861
$\operatorname{Temp}\left({ }^{\circ} \mathrm{F}\right)$

179.1

188.4

148.0

143.5

150.9

72.8

73.0

84.5

73.2

204.3

206.0

218.9

214.8

177.3

156.2

177.2

72.1

72.3

86.0

72.6

224.1

222.3

191.1

192.7

151.0

156.7

156.2

73.7

73.5

84.9

73.7

THERMOCOUPLE READINGS

DRYWELL NO. 3

T/C No. Temp ( $\left.{ }^{\circ} \mathrm{F}\right)$

854

853

852

851

850

849

848

847

846

845

844

843

812

841

840

839

838

837

836

835

834

833

832

831

830

829

828

827

826

825

824
177.7

186.8

139.6

136.4

139.3

70.1

70.0

82.1

70.0

198.0

203.6

214.2

217.2

173.5

174.5

173.7

71.6

71.7

86.5

71.7

224.0

221.9

189.2

189.3

150.7

154.3

73.5

73.8

85.8

73.8

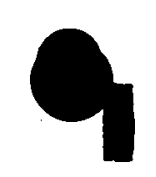


TABLE B-35

ISOLATED DRYWELL TEST - THERMOCOUPLE DATA

DATE : $\quad 5 / 28 / 80$

TIME: $4: 00 \mathrm{p} . \mathrm{m}$.

OPERATING HOURS: DRYWELL NO. 5: 12,054. DRYWELL NO. 3: 11,741

THERMOCOUPLE READINGS

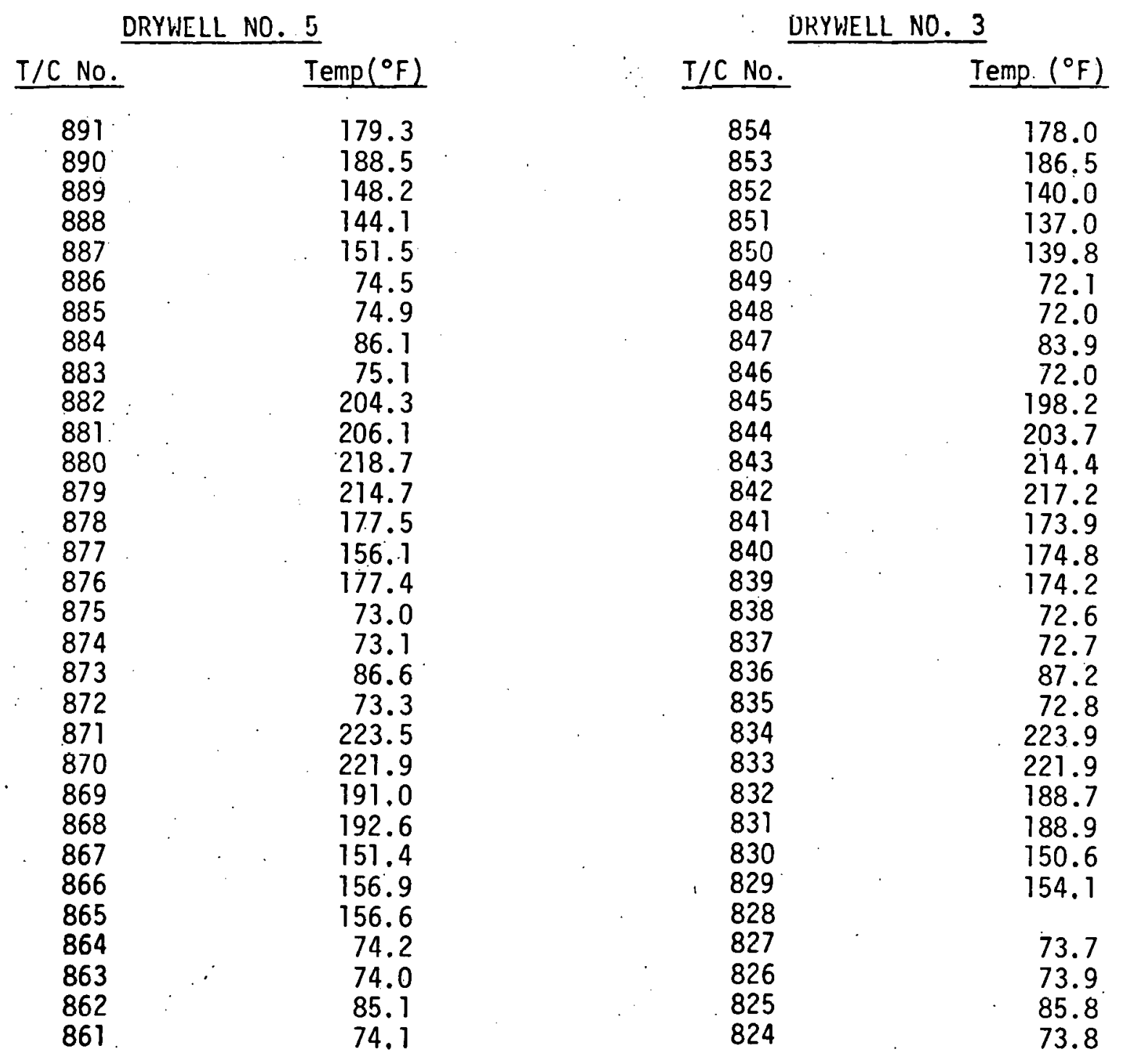


TABLE $\quad B-36$

ISOLATED DRYWELL TEST - THERMOCOUPLE DATA

DATE : $\quad 6 / 11 / 80$

OPERATING HOURS: DRYWELL NO. 5: 12,390 DRYWELL NO. 3: 12,077

\section{THERMOCOUPLE READINGS}

DRYWELL NO. 5

T/C No.

891

890

889

888

887

886

885

884

883

882

881

880

879

878

877

876

875

874

873

872

871

870

869

868

867

866

865

864

863

862

861
$\underline{\operatorname{Temp}}\left({ }^{\circ} \mathrm{F}\right)$

179.6

188.4

149.2

144.8

152.2

75.8

76.3

87.4

76.6

205.0

206.4

219.1

215.0

177.9

156.1

177.7

73.9

13.9

87.3

74.1

223.4

221.6

190.3

191.9

151.5

156.4

156.2

74.0

73.8

84.9

74.0
DRYWELL NO. 3

T/C No. Temp ( $\left.{ }^{\circ} \mathrm{F}\right)$

178.2

187.5

140.4

137.4

140.5

73.6

73.3

85.3

73.4

198.4

204.0

214.6

217.1

174.1

175.0

174.7

73.7

74.0

88.1

74.0

223.8

221.8

188.5

188.9

150.6

154.2

74.0

74.1

86.1

74.0 
TABLE $\quad B-37$

ISOLATED DRYWELL TEST - THERMOCOUPLE DATA

DATE : $\quad 6 / 25 / 80$

OPERATING HOURS: DRYWELL NO. 5: 12,726 DRYWELL NO: $3: 12,413$
TIME: 4:00 p.m.

\section{THERMOCOUPLE READINGS}

DRYWELL NO. 5

I/C No.

891

890

889

888

887

886

885

884

883

882

881

880

879

878

877

876

875

874

873

872

871

870

869

868

867

866

865

864

863

862

861
Temp $\left({ }^{\circ} \mathrm{F}\right)$

182.3

190.9

152.2

147.9

155.2

79.0

79.4

90.5

80.0

207.7

209.2

221.5

217.3

179.9

157.0

179.9

75.1

75.1

88.5

75.4

225.1

223.2

191.2

192.8

153.6

157.3

157.2

74.7

74.6

85.5

74.7
DRYWELL NO. 3

T/C No. Temp ( $\left.{ }^{\circ} \mathrm{F}\right)$

854

853

852

851

850

849

848

847

840

845

844

843

842

841

840

839

838

837

836

835

834

833

832

831

830

829

828

827

826

825

824
181.9

189.7

144.3

141.2

143.4

76.9

76.4

88.6

76.7

201.6

206.1

217.0

219.1

176.2

177.1

176.7

75.0

75.3

89.5

75.4

225.5

223.3

189.2

189.5

151.3

154.9

74.6

74.7

86.6

74.5 
TABLE B-38

ISOLATED DRYWELL TEST - THERMOCOUPLE DATA

DATE : $7 / 16 / 80$

TIME : $\quad 4: 00$ p.m.

OPERATING HOURS: DRYWELL NO. 5: 13,230: DRYWELL NO. $3: 12,917$

\section{THERMOCOUPLE READINGS}

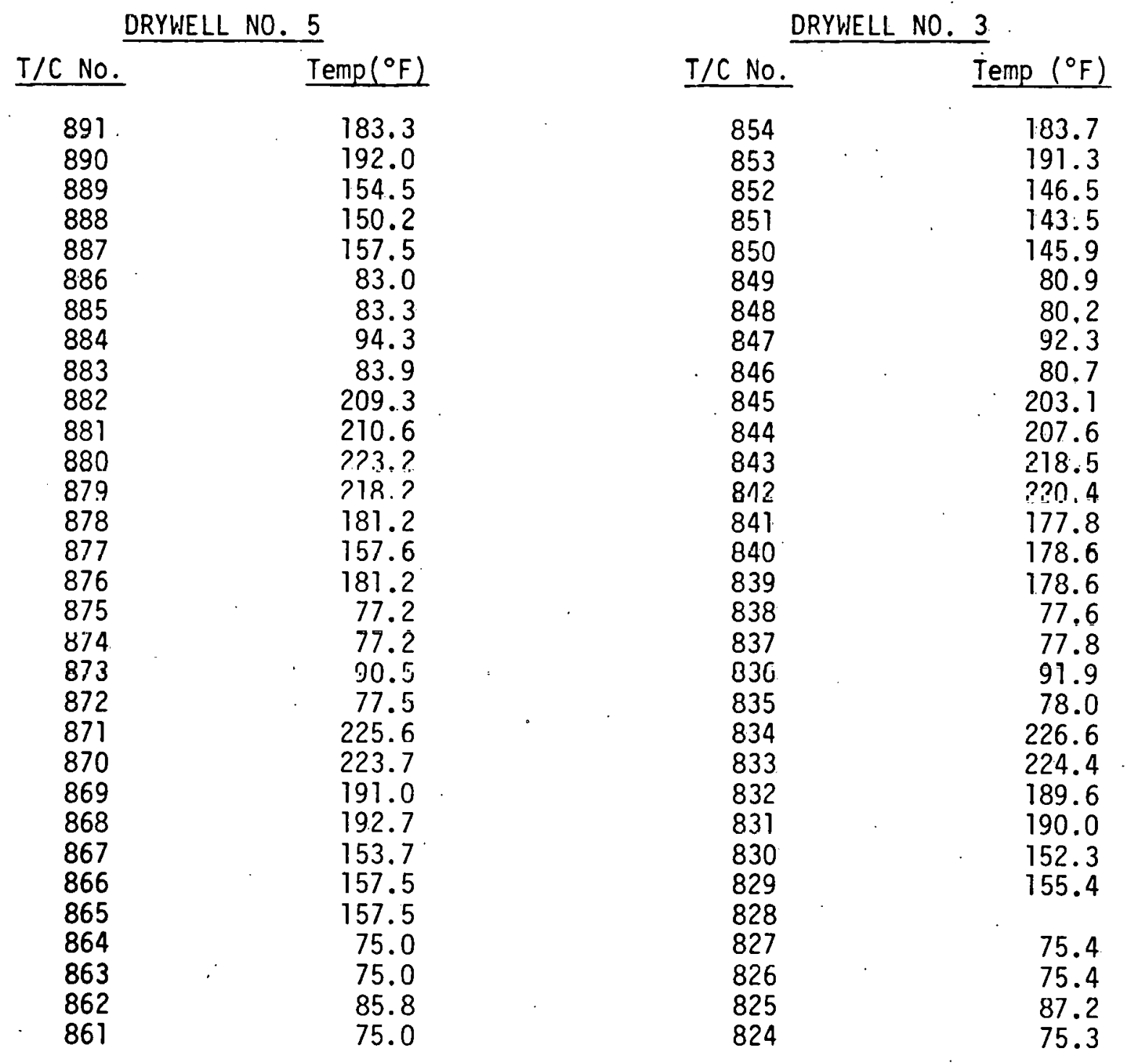

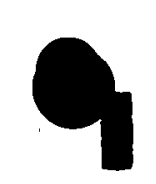


TABLE $\quad B-39$

ISOLATED DRYWELL TEST - THERMOCOUPLE DATA

DATE : $7 / 30 / 80$

OPERATING HOURS: DRYWELL NO. 5: 13,566 DRYWELL NO. 3: 13,253

\section{THERMOCOUPLE READINGS}

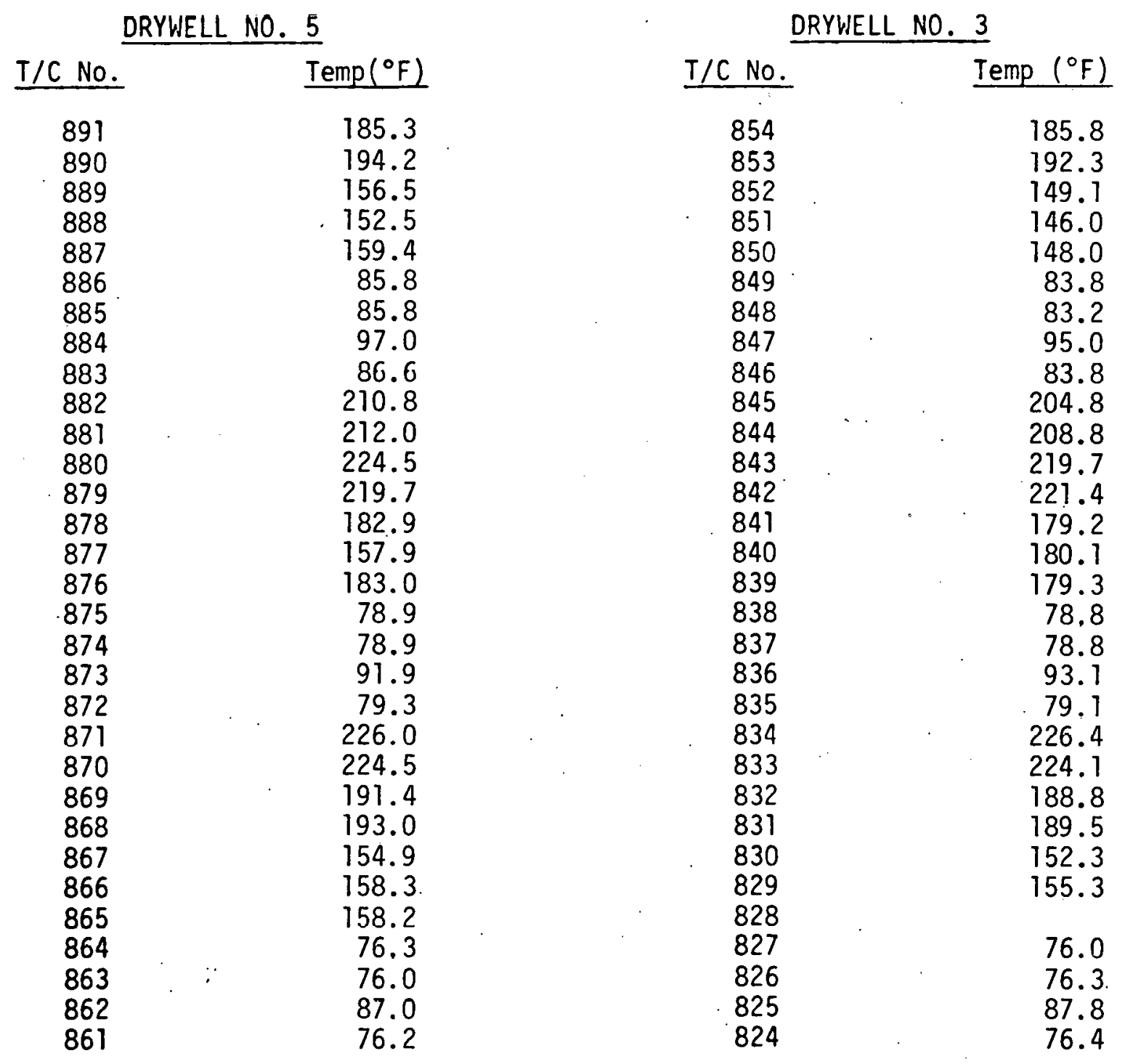


APPENDIX C

TEST DATA ILLUSTRATIONS

This appendix provides supplementary test data illustrations. 


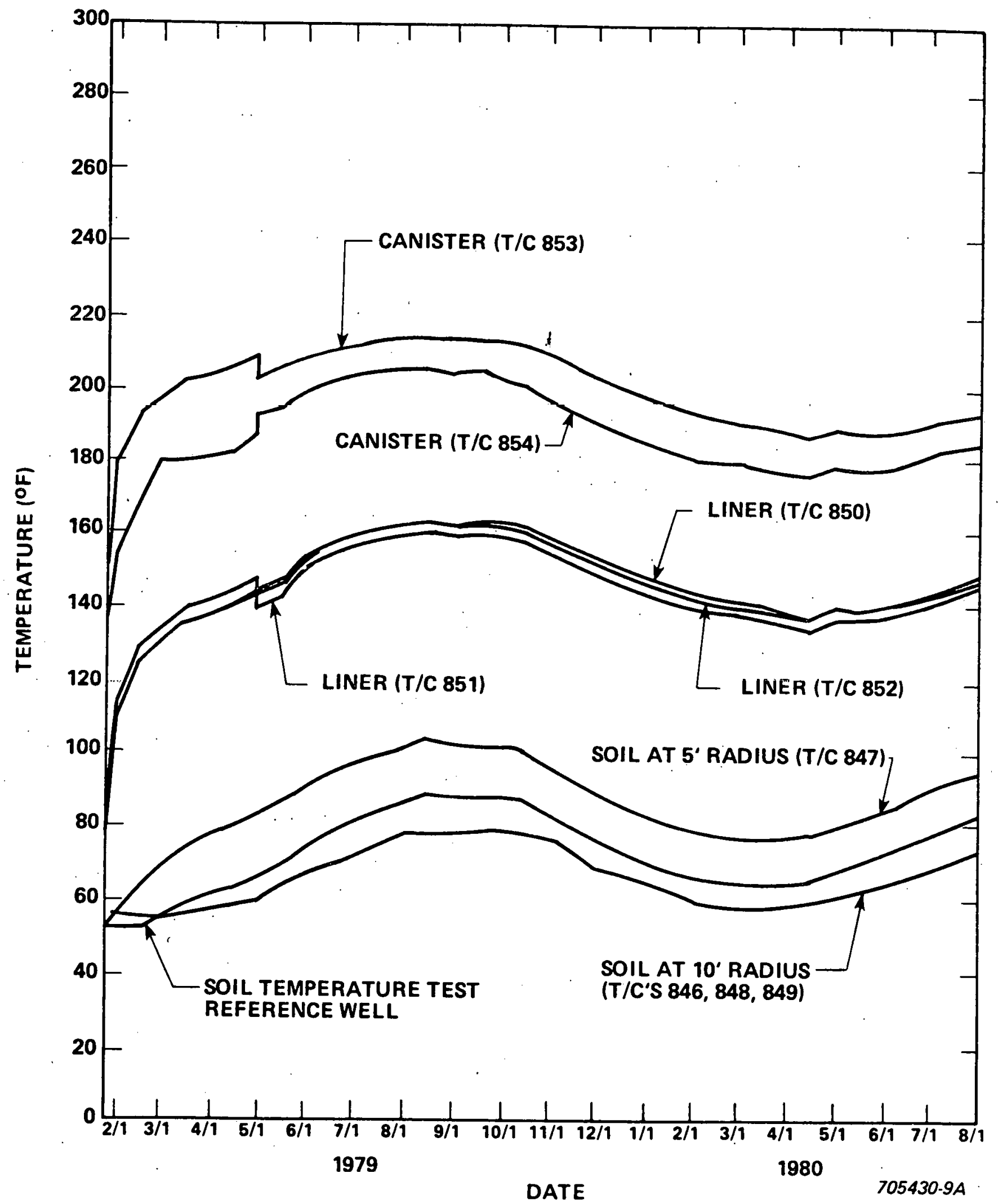

Figure C-1. Drywe11 3 Canister, Liner, and Soil Temperature Distributions at About 85 Inches Below Ground Leve1 


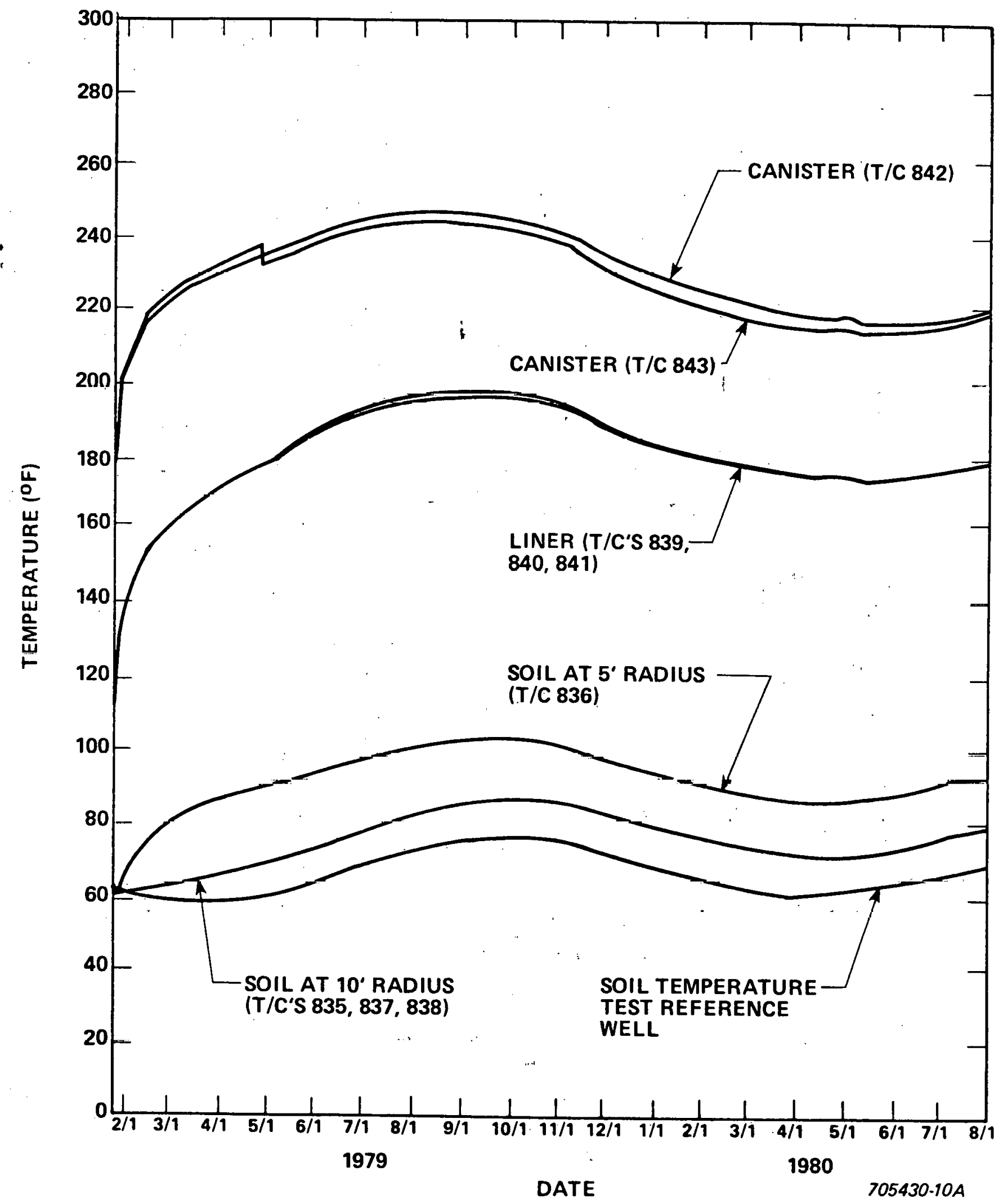

Figure C-2. Drywe 113 Canister, Liner, and Soil Temperature Distributions at About 145 Inches Below Ground Leve 1 


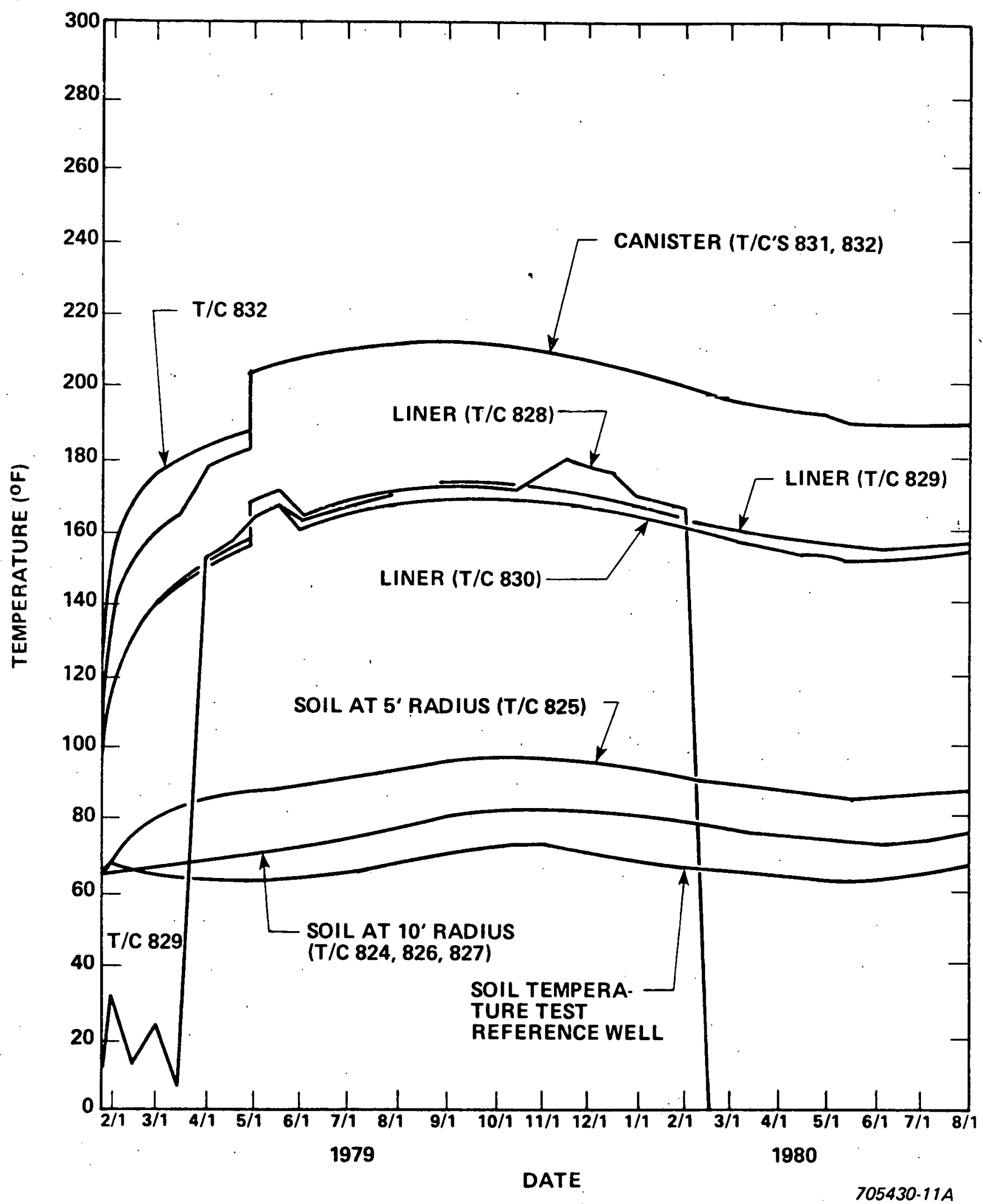

Figure C-3. Drywell 3 Canister, Liner, and Soil. Temperature Distributions at About 205 Inches Below Ground Leve] 


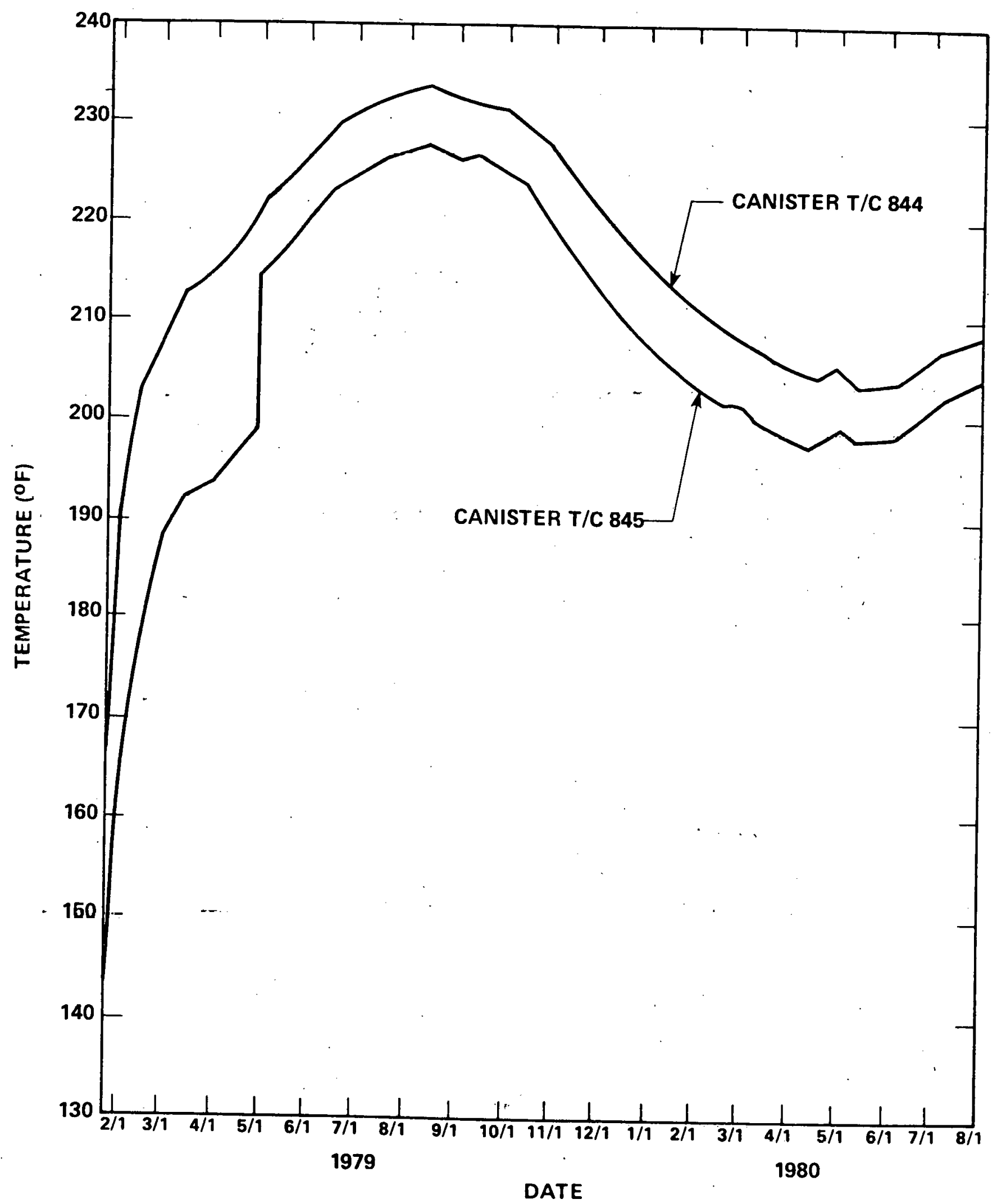

$705430 \cdot 12 A$

Figure C-4. Drywell 3 Canister Temperature Distribution at 116 Inches Below Ground Leve 1 


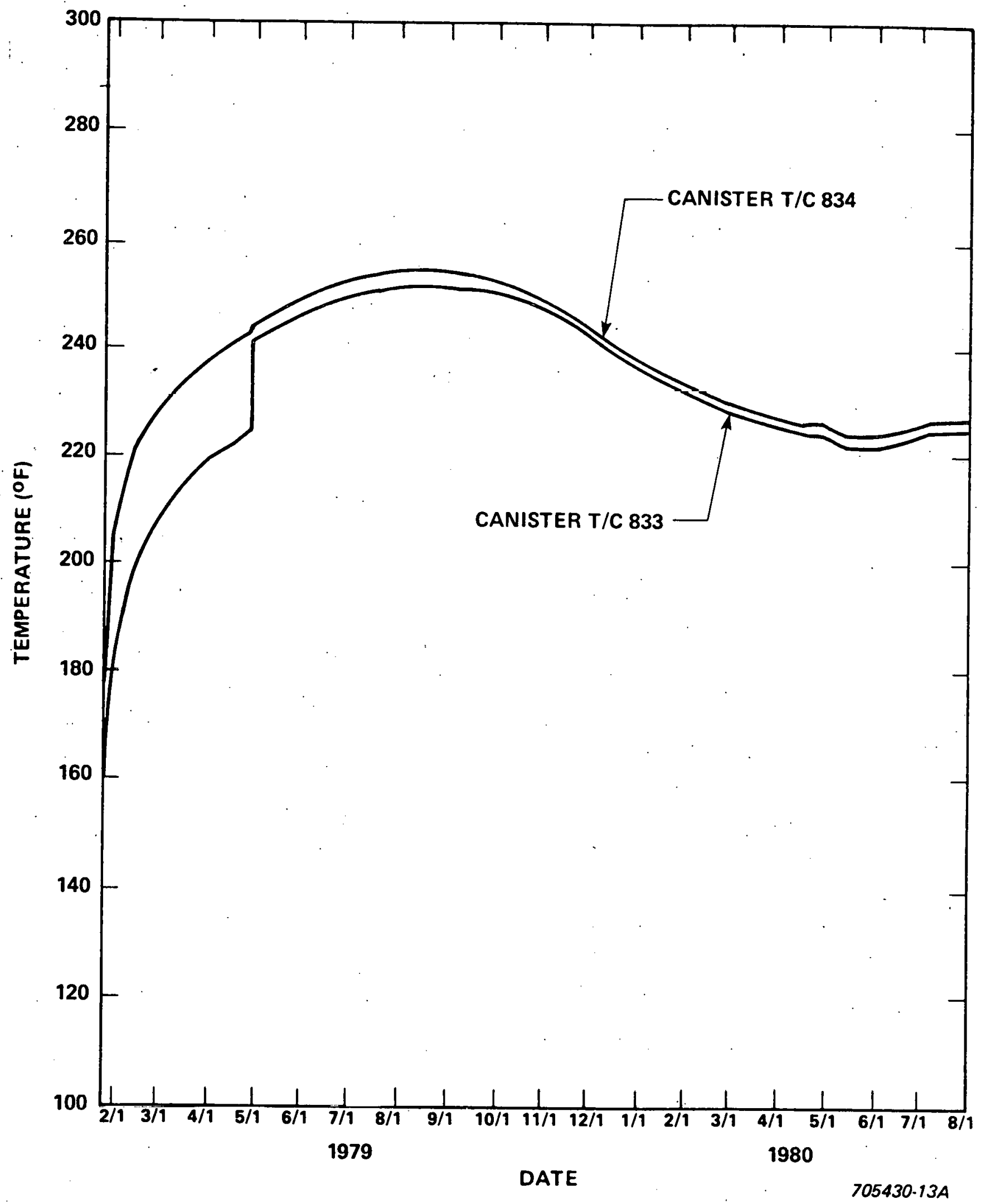

Figure C-5. Drywell 3 Canister Temperature Distribution at 176 Inches Below Ground Level 


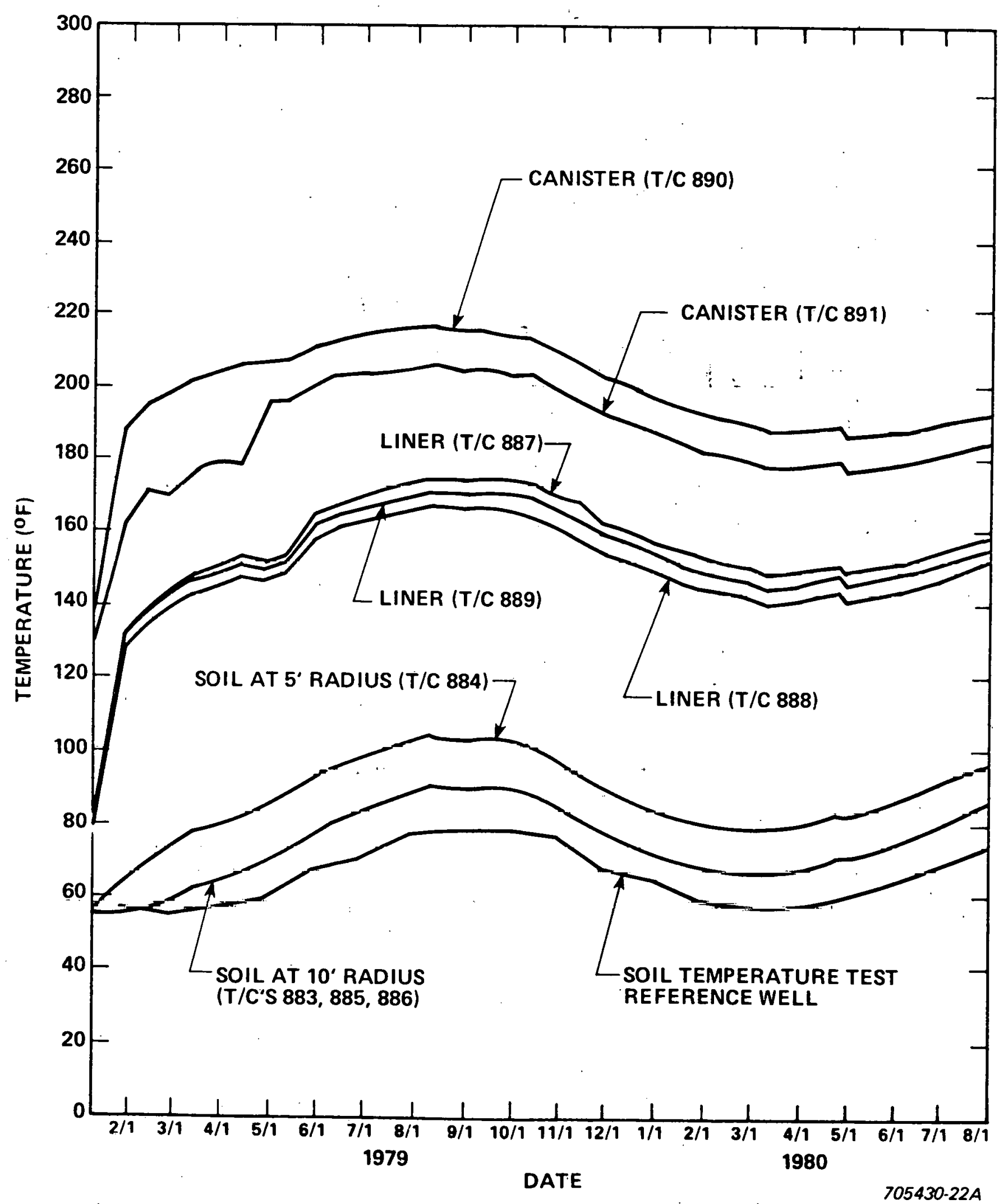

Figure C-6. Drywe11 5 Canister, Liner, and Soil Temperature Distributions at About 85 Inches Below Ground Level 


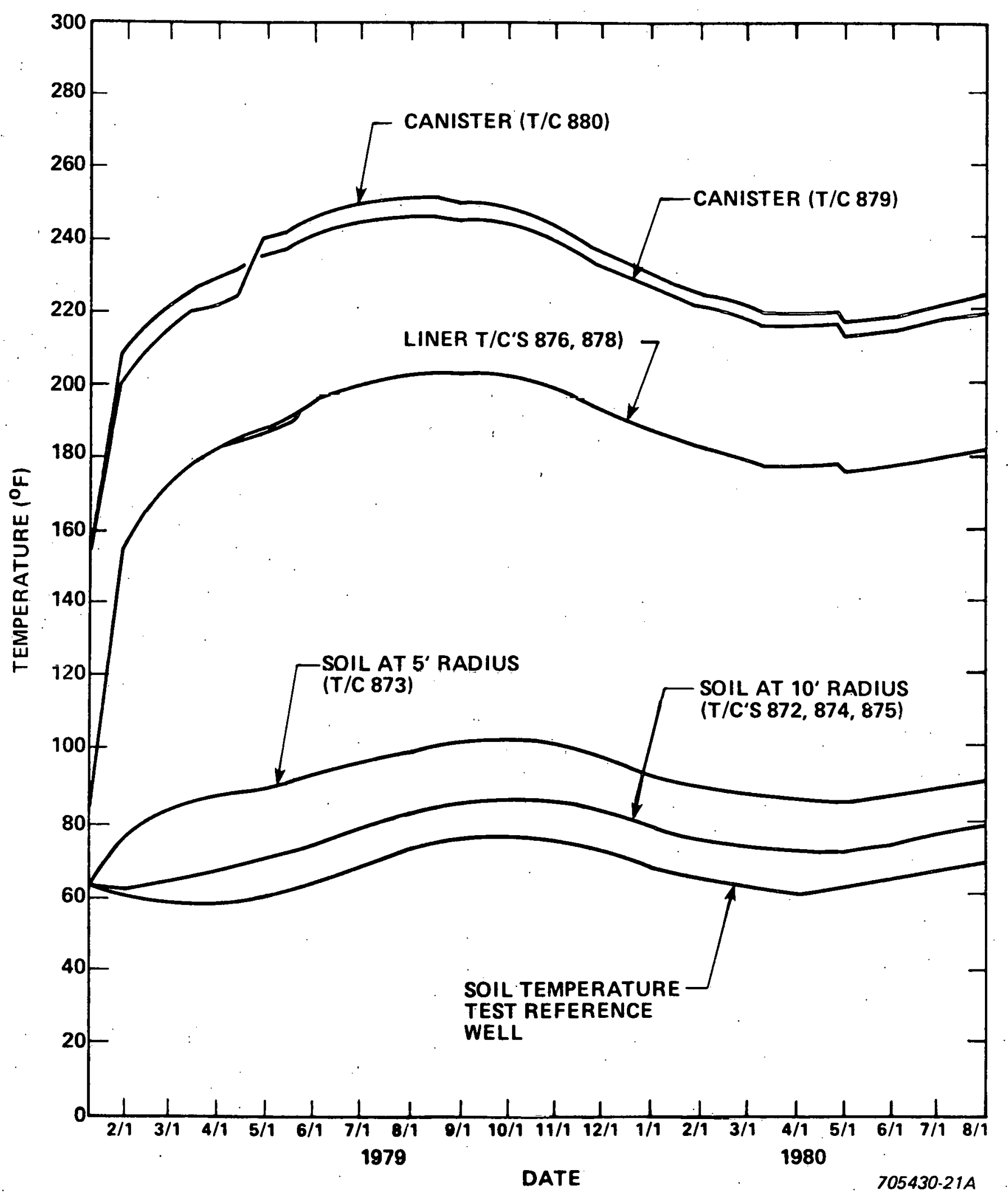

Figure C-7. Drywell 5 Canister, Liner, and Soil Temperature Distribution at About 145 Inches Below Ground Level 


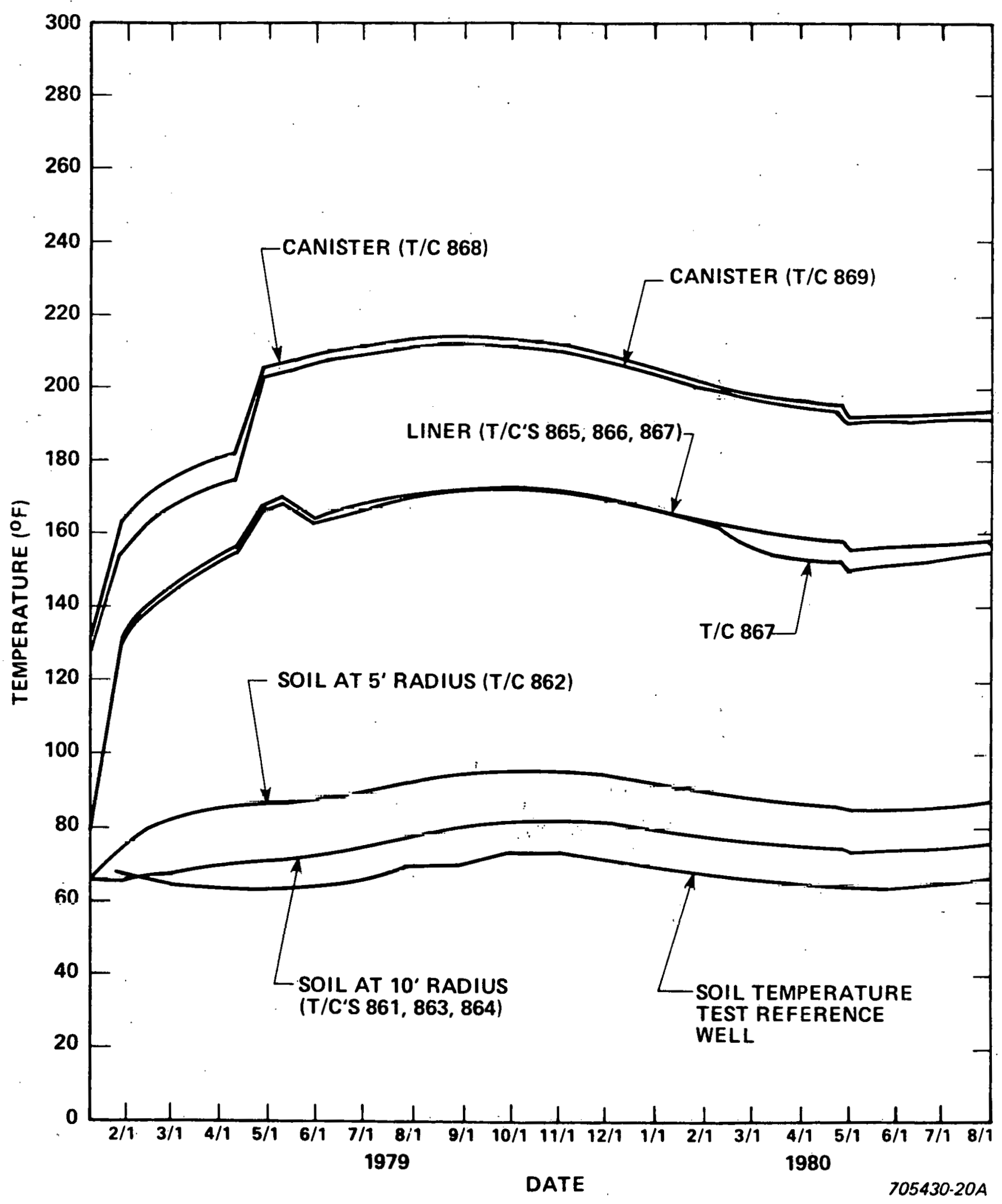

Figure C-8. Drywell 5 Canịster, Liner, and Soil Temperature Distributions at About 205 Inches Below Ground Level 


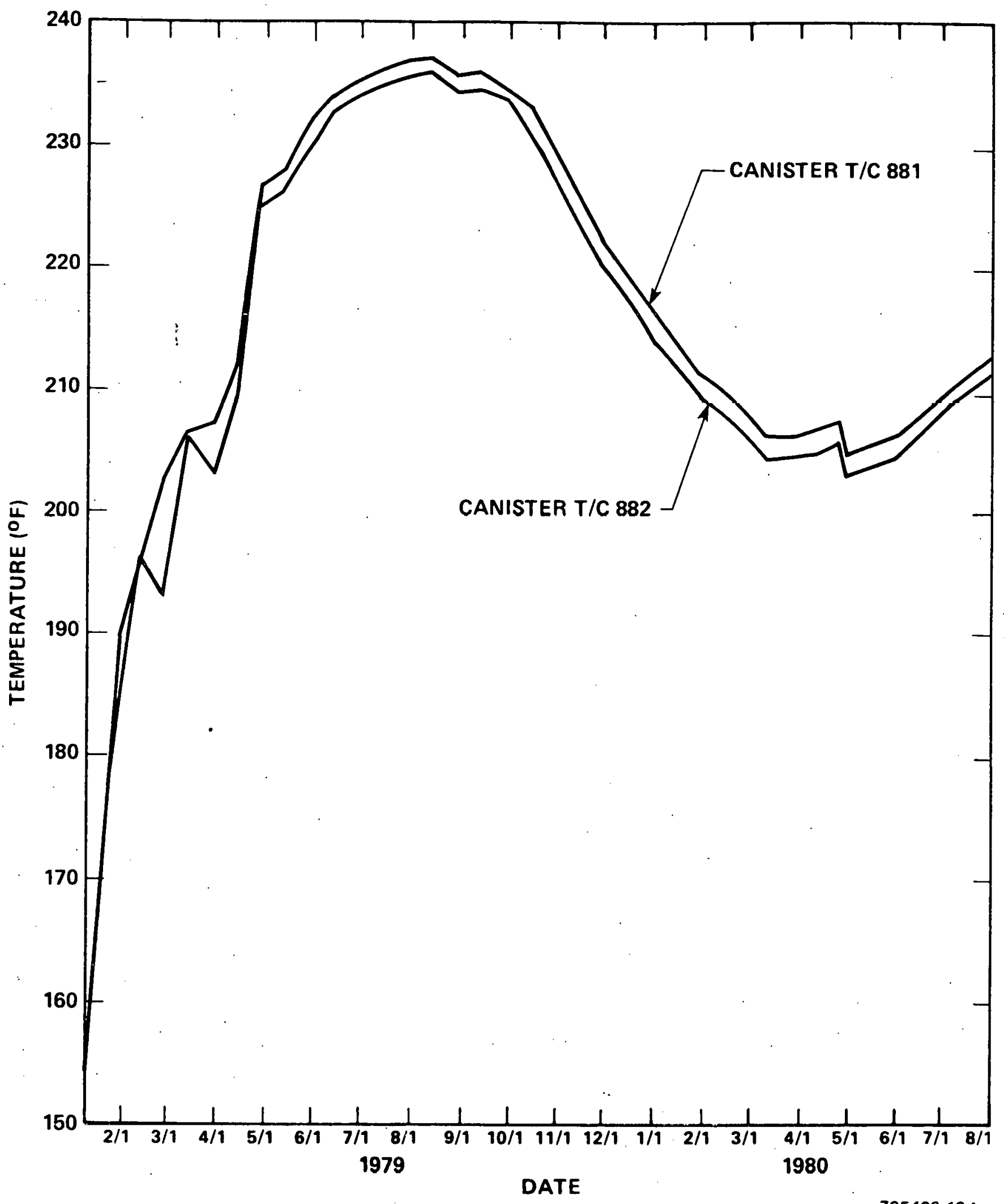

705430-19A

Figure C-9. Drywe11 5 Canister Temperature Distribution at 116 Inches Below Ground Leve1 


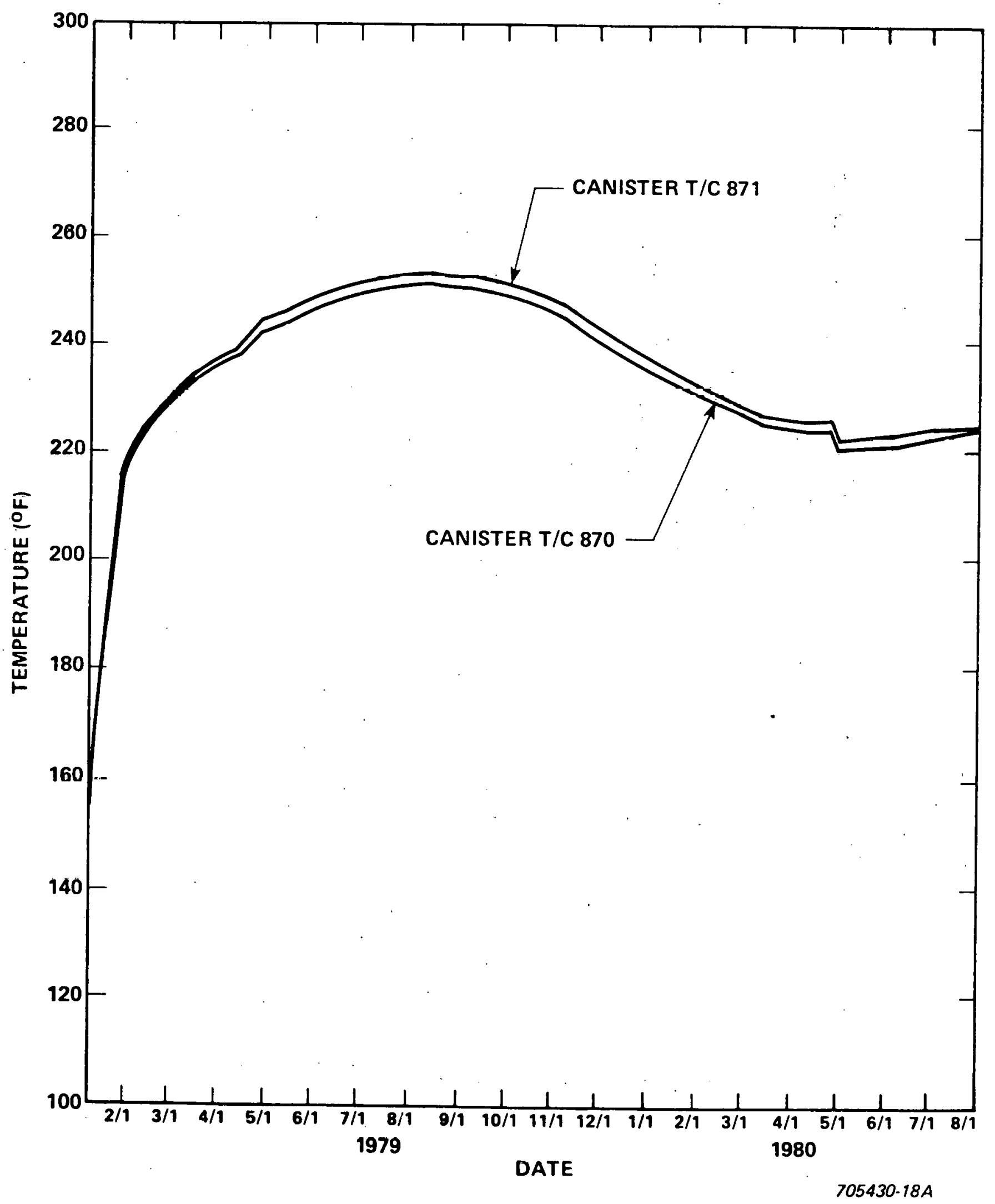

Figure C-10: Drywe11 5 Canister Temperature Distribution at 176 Inches Below Ground Level 


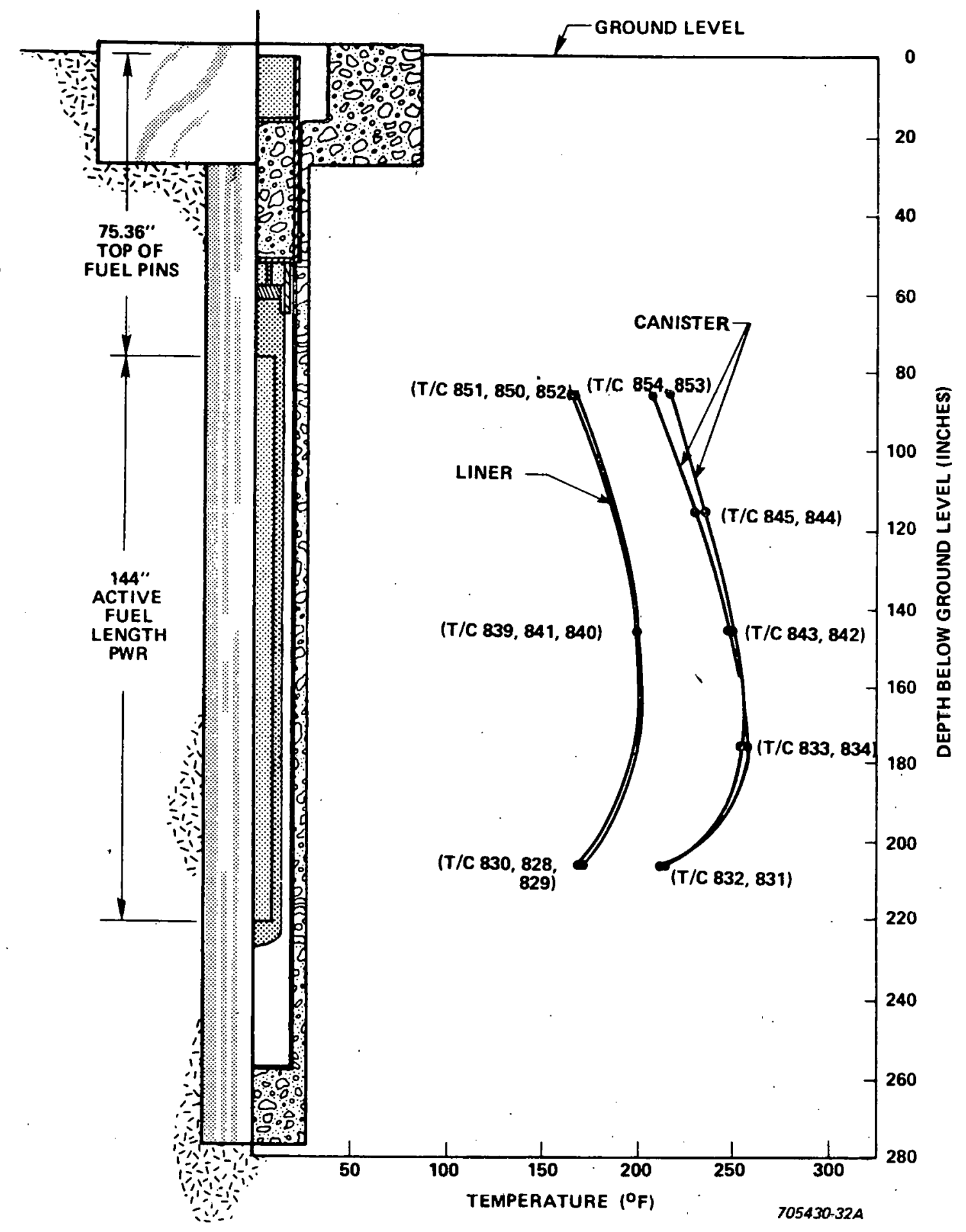

Figure C-11. Drywell 3 Axial Canister and Liner Temperature Profiles, August 15, 1979 


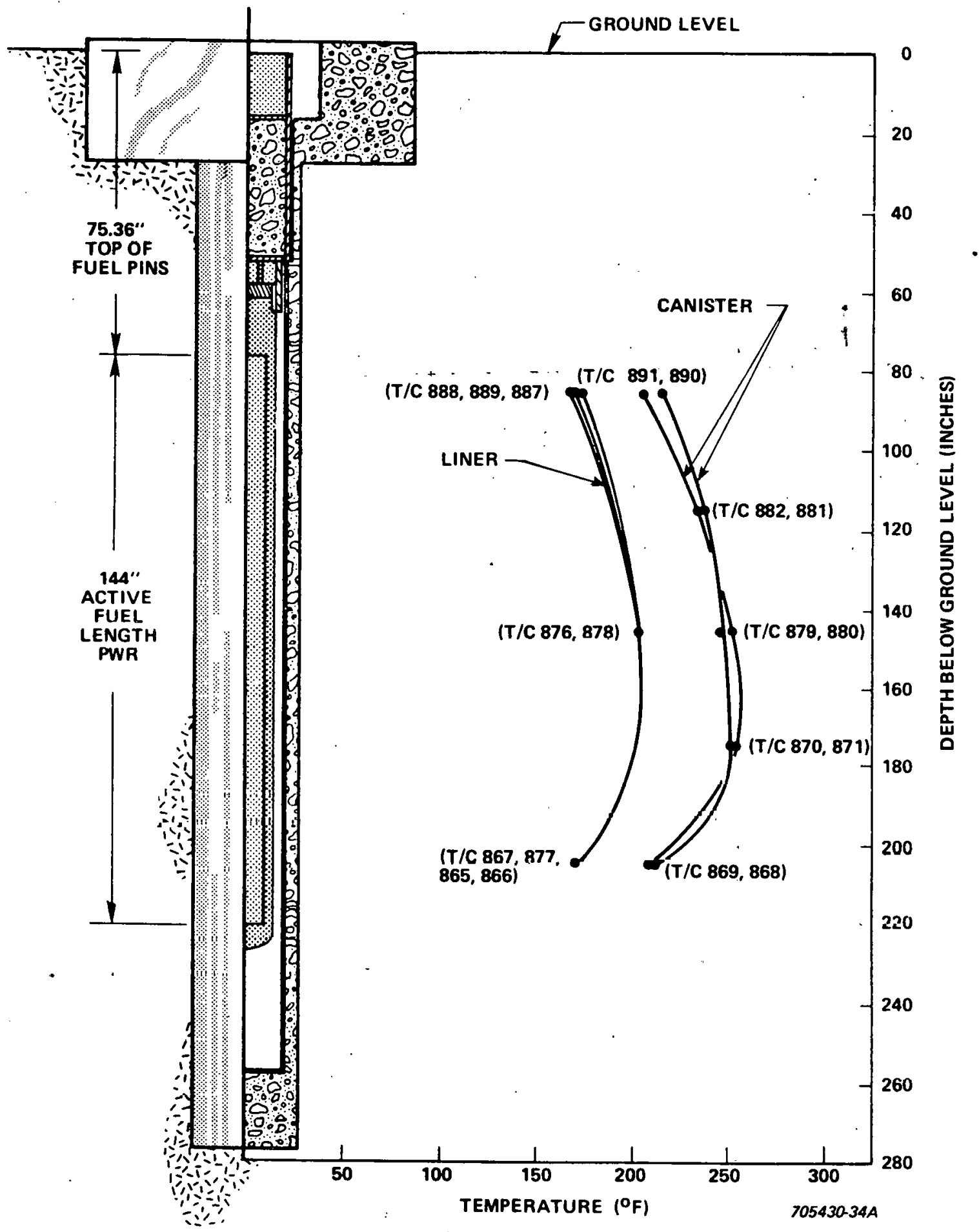

Figure C-12. Drywell 5 Axial Canister and Liner Temperature Profiles, August 15, 1979 


\section{APPENDIX D}

\section{TAP-A INPUT AND OUTPUT}

This Appendix contains a copy of typical computer printout of the TAP-A input data and output data. Model predicted temperatures are provided in the output printouts for Drywell 5 on the first day of each, month from February, 1979 to Augusl, 1980. The nodes are ident ified and their locations are shown in Figures 28 and 29. For an explanation of the input data and its format, see Reference 6 . 
TAP-A INPUT DATA

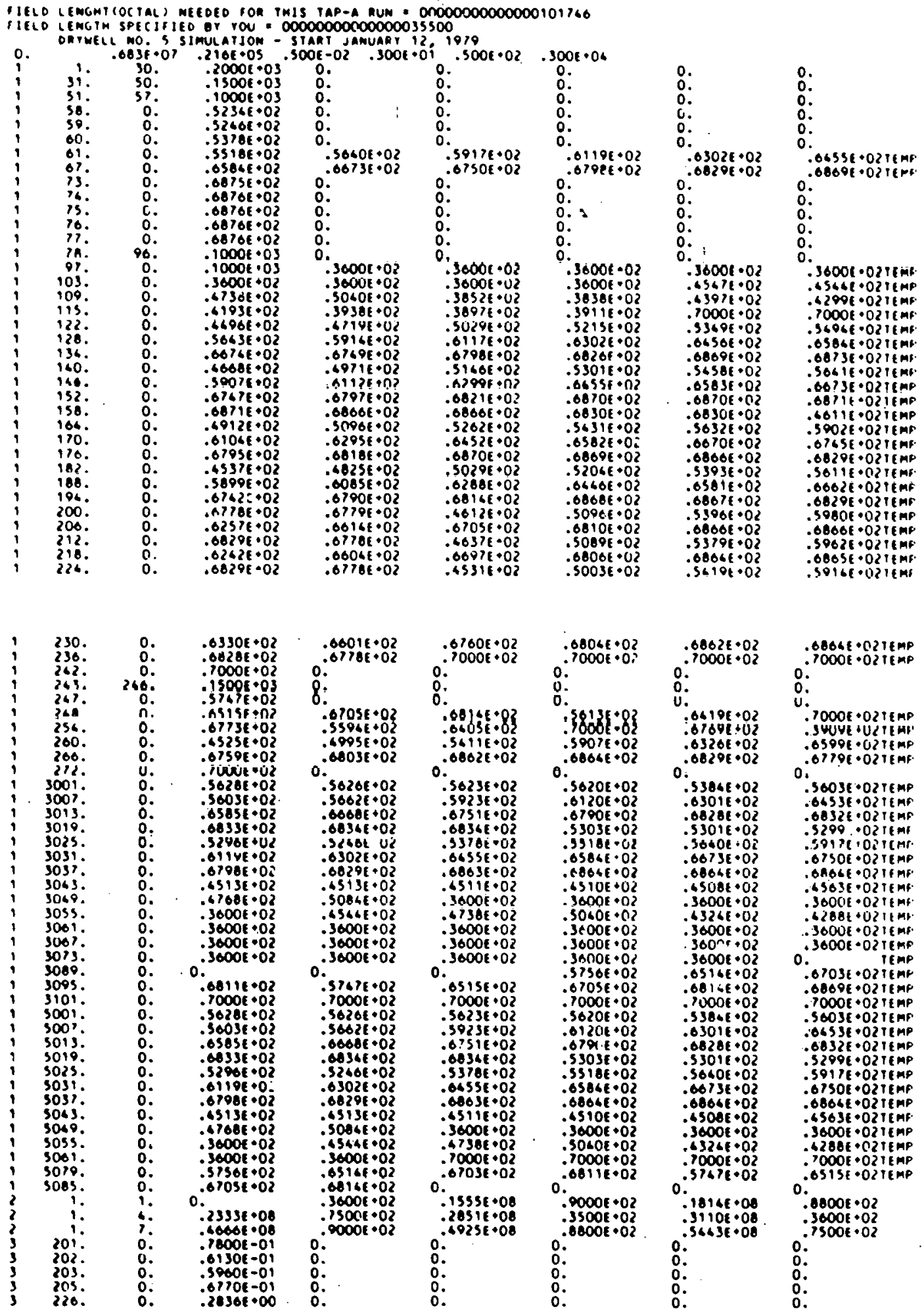


TAP-A INPUT DATA (Cont'd)
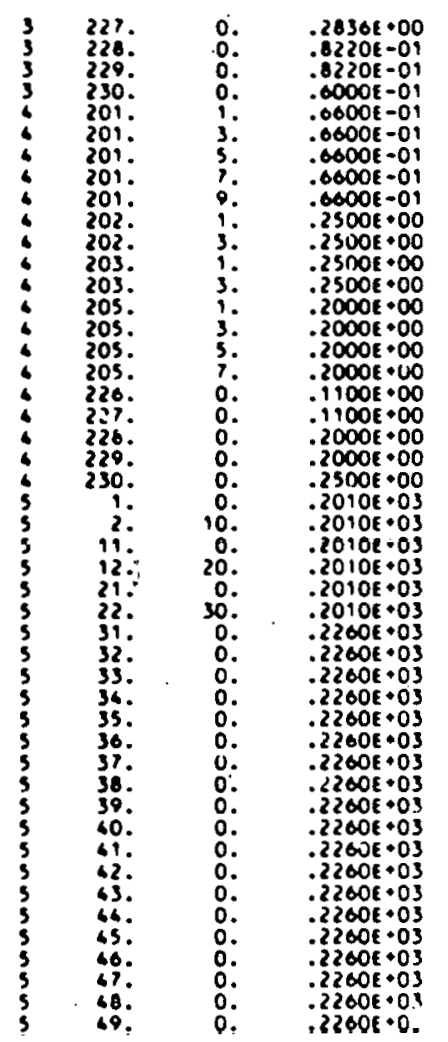

:.: $\quad$ :

$.10201-05$

$.23600-05$

. S082t-0s

$.00206-05$

$.8064 \mathrm{E}-05$

$.20201-04$

$.10626-06$

$.15386-04$

$.15386-04$

$.82001-05$

$.23156-03$

$.53266-03$

$.263110-06$

$.20206-06$

$.31625+01$

$.31626 \cdot 01$

$.31620+01$

$.31626 \cdot 01$

-3162E+01

-3142E+01

$.31626+01$

$.16296+03$

$.31426+01$

-3162E+0

.31626.01

$31626+01$
$31+26+01$

.3142601

$.3162 E \cdot 01$

.31626001

$.31426+01$

- 3142 E०01

-3162E०01

$.3162 E \cdot 01$

$.3142 E \cdot 01$

::

$.10001 \cdot 03$

$50006 \cdot 03$

.9000 - 03

$.1300 E \cdot 06$

$.60001 \cdot 02$

$.20006 \cdot 03$

$20001 \cdot 03$

$6000 \mathrm{E} 02$

$20006 \cdot 03$

$.6000 t \cdot 03$

0 .

0.

0 .

$.40000+01$

.60001 .01

- 1zivitus

$.12001+02$

$.20001 \cdot 02$

$.20008+02$

$.1200 \mathrm{E}+02$

$.2000 \mathrm{E}+02$

$.10006 \cdot 01$

-1000e 01

.51006 .01

.51096 .01
.51096 .01

$.5109+01$

. S109E001

.51098 .01

. $5109 E+01$

- S100E+01

$.5109 \mathrm{f} \cdot 01$

$.1300 \mathrm{0} 02$

$.2000 E^{\circ} 02$

$\begin{array}{ll}0 . & 0 \\ 0 . & 0 \\ 0.0 & 0\end{array}$

o.

$.66006-01$
$.06008-01$

$.0600 E-01$
$.0600 E-v 1$

0.

$.25006 \cdot 00$

$.25008 \cdot 00$

.25006 .00

$.2000 \mathrm{E} \cdot 00$

$.20006 \cdot 00$

$.20006 \cdot 00$

$\therefore$.

0 .

0.

$0.7300 E \cdot 09$

$1000 \mathrm{0} \cdot 02$

- is suvt tu

$.10006 \cdot 02$

$.1300 t \cdot 01$

.35006 .01

.3500 - 01

$.3500 \mathrm{t} \cdot 01$

-1000E 01

.1000E-01

$.71006 \cdot 09$

$.3200 E \cdot 01$

$.100 \mathrm{OE} \cdot 02$

$.1600 \mathrm{E} \cdot 02$

13200.02

$.1000 \mathrm{0} .02$

020060

.1600 • 02

.5200E. 01

.63001.01

$.37506 \cdot 00$

:3ysne •nก

$0.10208-05$

$.3009 E-05$
$.6390 E-05$

0.

- $20208-0$

$.20206-06$

$.20206-06$

.10626-06

$13126-06$
$1165 e-06$

$.92306-05$

0.
$0:$
$0:$
$0:$
0.
0.
0.
0.

.

o.

c.
0.
0.

0 .

o.

o.

o.

o.

o.

noos

nOoE

MOOC

MODE

$.3162 E \cdot 01$

$.4000 E \cdot 01$

$.37508+00$

$13618+02$
$: 13618 \cdot 02$

.0000 .01

$.60006 \cdot 01$
.12006 .02

$.2000 \times 02$

$.1300 \mathrm{0} \cdot 02$

.51000 .02

$.40006+02$

.0009 . 01

.66092 .01

.8009 *01

$.60091 \cdot 01$

.0009 .01

$.6009 \mathrm{E} \cdot 01$

.6009e

.600901

.0609 0

$.6009 \mathrm{e}$

.6009 .

$.6009 \mathrm{E} 01$

.6009 .

$.1300 \mathrm{0} 02$

$.2000 k+02$

.12000 .02

$.40006+01$

$.4000+01$

.4000 . 01

.40006 .9

$.12,0 \mathrm{t} \cdot \mathrm{Cl}$

$1200 \mathrm{E}$

.

$.2000 t \cdot 02$

$.20006+02$

$.13006 \cdot 02$

$.13006 \cdot 02$

$.13006 \cdot 02$

$.51000+02$

.51006 .02

- slo0e.0?

$\$ 12006.02$

$.2000 \mathrm{E} \cdot 02$

$.5900 \mathrm{P}+0$

1000 e.

1000 E. 01

1000e

.1000E. C

$.5000 \mathrm{~B} 00$

$5900 \mathrm{E} \cdot 0$

- 1070E.

$.52000^{\circ}$

.1000 .02

.1000 .0

$16001 \cdot 02$

.13206 .02

.92001 .01

18000.02

S200k

3675E:0

$18000^{\circ}$

$\because 8000.02$

$\because 800102$

$18001 \cdot 02$

$-18001.02$

$\$ 16001.02$

$.1300 \mathrm{f} \cdot 02$

- Sircer +0

-13008.02

.9000 . 01

16001.02
.9001 .02

$-1300 \mathrm{0}+02$

$\$ 0006 \cdot 0$

$\checkmark 6006 \cdot 02$

-

.5000 E 02

1 $1300 \mathrm{0} .02$

-

$\because 0006$

10006.61
.10000 .01

$.10006 \cdot 01$

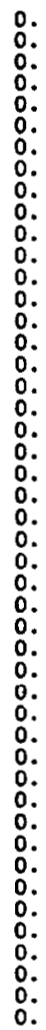

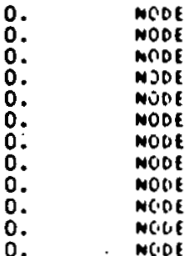

NOLE

NOOE

MODE

MODE

NOUE

MODE

noloe

nous

motie

mote

nool

ned

node

ncue

Nolle

. 31625001

$.13006 \cdot 02$ 
TAP-A INPUT DATA (Cont'd)

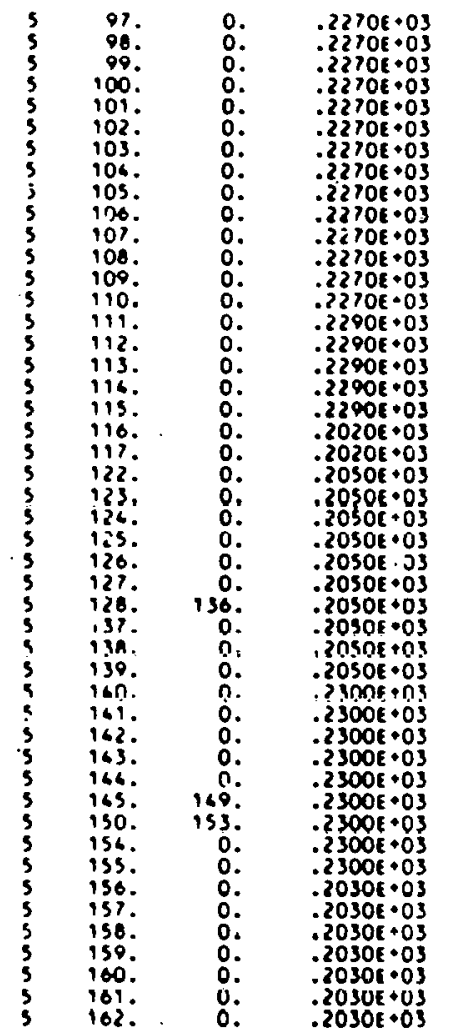

\begin{tabular}{|c|c|}
\hline 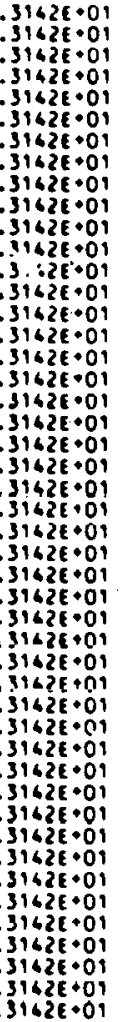 & 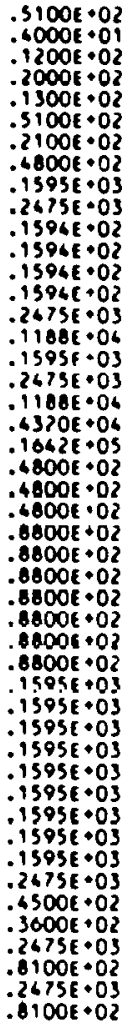 \\
\hline
\end{tabular}
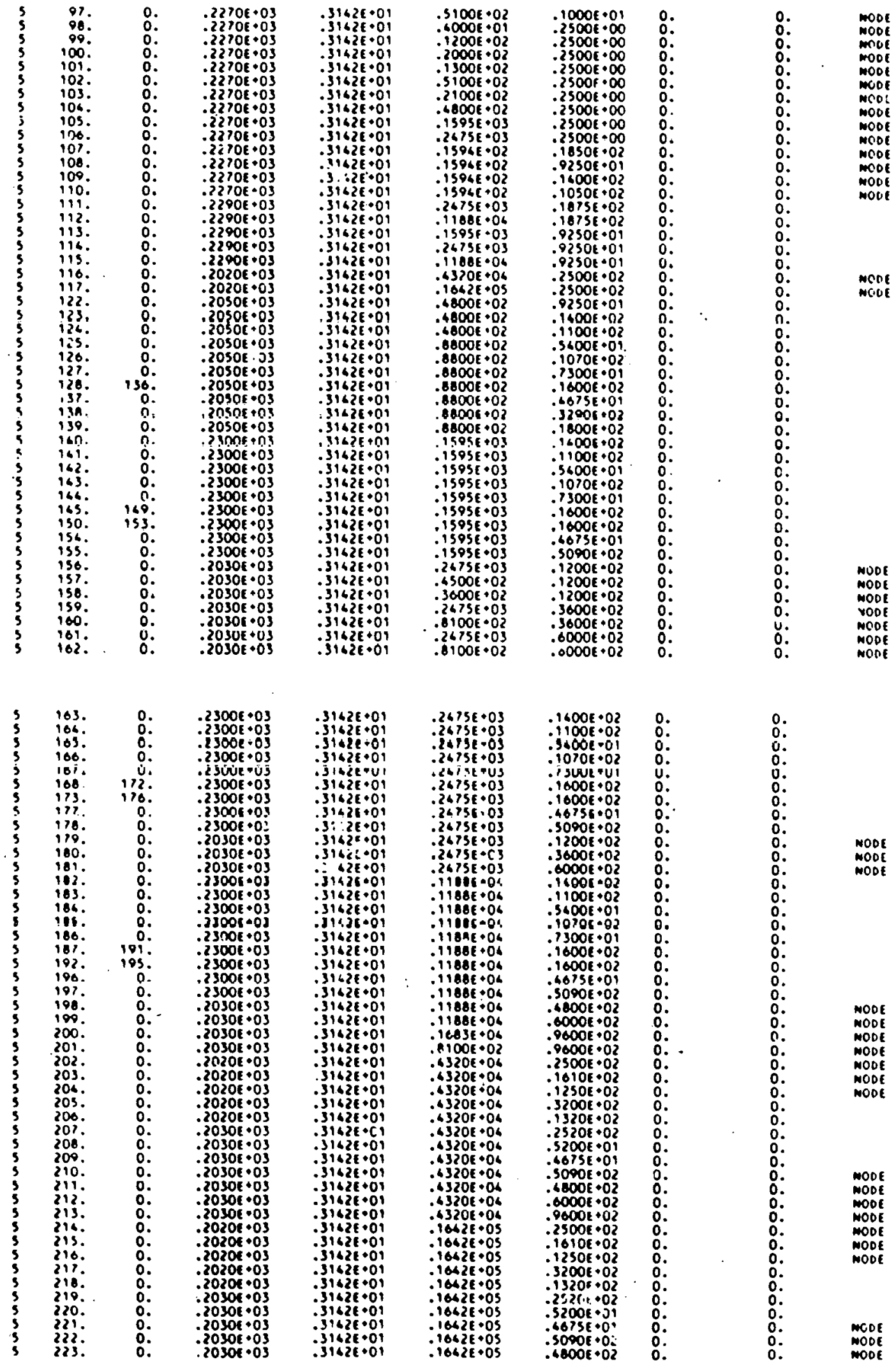

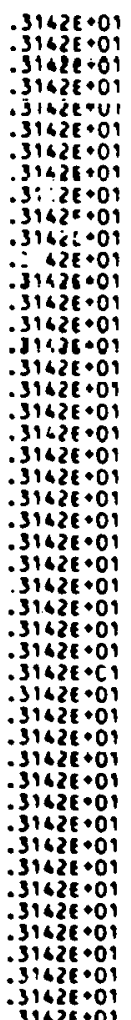
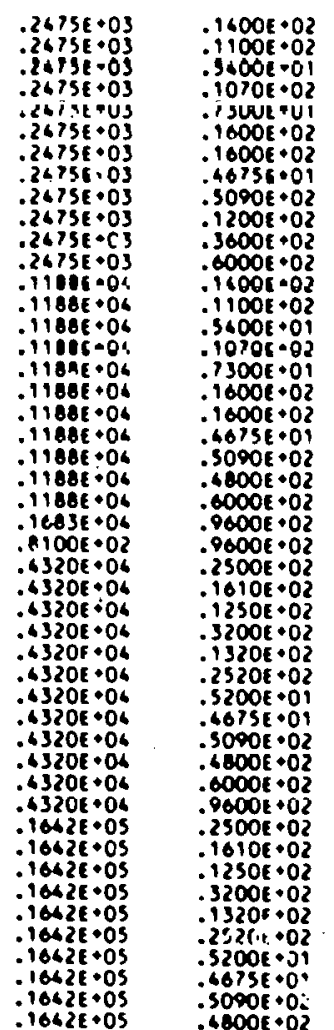

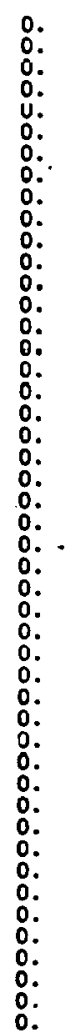

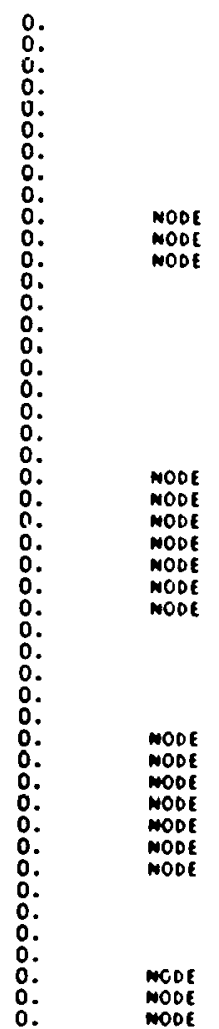


TAP-A INPUT DATA (Cont'd)
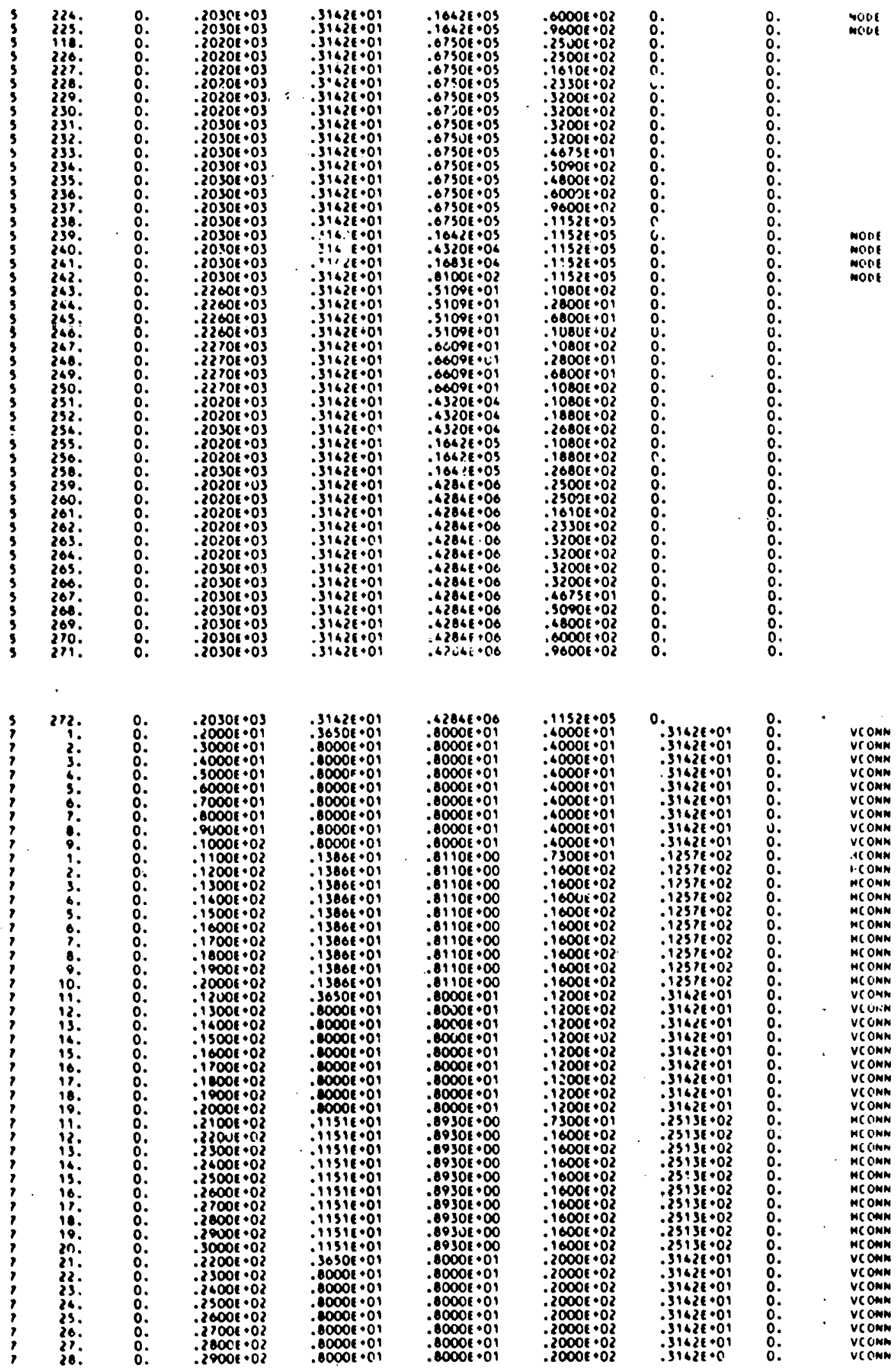

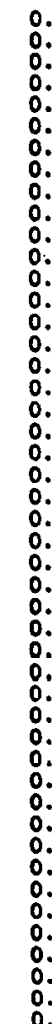

.20301 .03

$.31628 \cdot 0$

.62846 .00 .0000 . $80001+01$
$.80001+01$ .80000 .01 $8000 \mathrm{~B} \cdot 0$ -8000E .0000 . 01 .8000 . 01 $.81101 \cdot 00$ .8110 .00 . $61108 \cdot 00$ .8110 +00 $.81106 \cdot 00$ $.8110 e+00$ .8110 .00 .8110 . 00 . .8008 . .0000 +0 .0000 e 01 .80001 .01 .80001 .01 .8000 + +01 .80301 .00 .80301 .00 :eyor •00 . $.89301 \cdot 00$ $.09301 \cdot 00$ . e0sue •00 $.89301+00$ .0000 • 01 .8000 + 01 .8000 • 01 .0000 r 01 $.80001 \cdot 01$ .000i .8000 . 01 .80001 .01

$.11522 \cdot 05$ 4000 E.09 $.40000 \cdot 01$ 4000 • 01 $\$ 000$ r. 01 40001.01 $.0008 \cdot 01$ 年 1300e (5001.0 1000 e. 02

1000e.02

(1)

1000 . 02

16006

1000 e 02

1000e

$.1000 \mathrm{H} \cdot 02$

$12006 \cdot 02$

$1200 \mathrm{e} \cdot 02$

-1200e.02

1200e.02

$13001 \cdot 02$

1200e.02

1300e.02

12008.02

-1700

$1000 \mathrm{E} \cdot 02$

$10001 \cdot 02$

1600e.02

(1)

1000 .02

1000

1000

1000

(1)

(000)

.20008 .02

2000r.0a

$.20008 \cdot 02$

.20000 .02

$.20001 \cdot 02$
0.

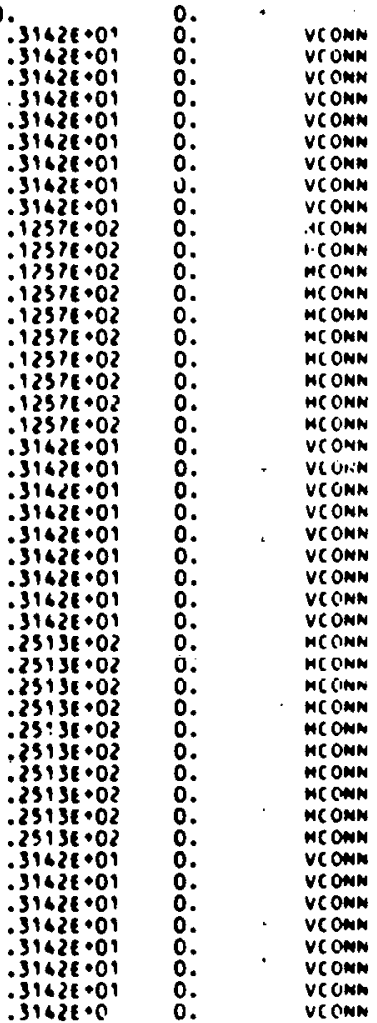


TAP-A INPUT DATA (Cont'd)

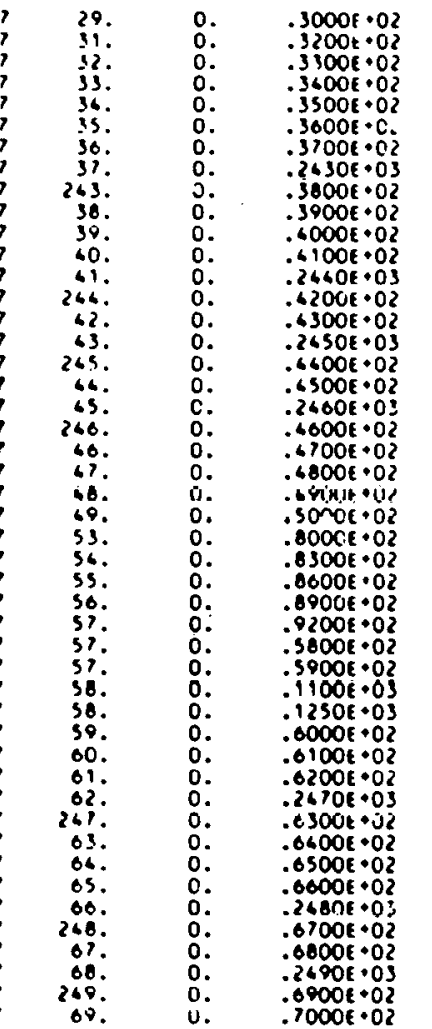

\begin{tabular}{|c|c|}
\hline 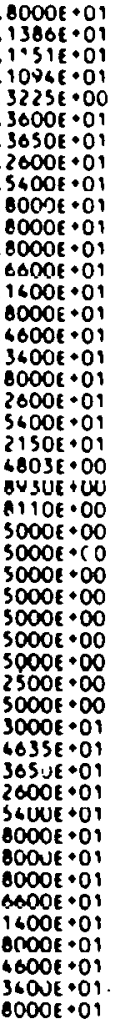 & 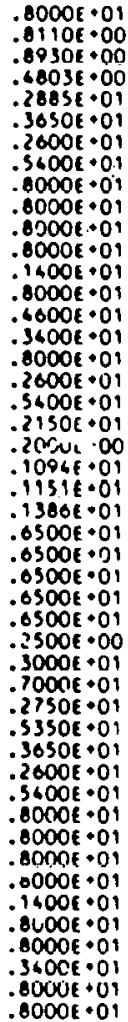 \\
\hline
\end{tabular}

$.20006 \cdot 02$ $.35006 \cdot 01$ $.35008 \cdot 01$ .66006 .02 $.36006 \cdot 02$ .51006.01 .51096.01 .5109t+0! .51006 .01 .S1086.01 .51006.01 .51006 .01 $.51096 \cdot 01$ .5109E.01 S S1006 01 .5109t-01 .5109E.01

.31092 .01

.51096.01

.5109E+01

-3,505.00

.37500 .00

.31626 .01

.3162Eण

.31621 .09

$.39625 \cdot 01$

$.3632 \cdot 01$

-31628.01

-31421.01

.31621 .01

.31621 .01

-3162E.01

$.31621 \cdot 01$

.31621009

$-31622 \cdot 01$
.31622 .01

$.31622+01$

$.314 .5+01$

-3162t+U1

$.31626+01$

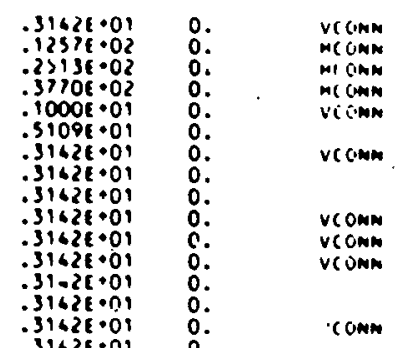

उ16260

.316260

316280

.31626 .01

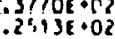

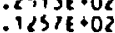

$.4000 \cdot 5$

$.12006 \cdot 02$

.1301E.02

$13016 \cdot 02$

$5100 E \cdot 02$
$19006 \cdot 02$

$008 \cdot 0$

15968.02

4608.02

.

.

(1)

$.00098 \cdot 01$

000801

$0809 E \cdot 01$

.

0009e.

.6609 . 01

.600\% 01

$.6009 \mathrm{.01}$

$6008 \mathrm{E} \cdot 01$

$.00 n 96+{ }^{4}$
$.5600 \mathrm{0}+0$

$.26006 \cdot 09$

$.25006 \cdot 03$

.110060

$\% 3000: 0$

$.15102 \cdot 03$

$\because 350$ - 03

$\because 500 \mathrm{E}+0$

$.1580 \mathrm{E}+03$

$.93006 \cdot 02$

:

$.9600 \mathrm{CO} \cdot 02$

. Ainnif tn

$.05: 06 \cdot 02$
$.85006 \cdot 02$

$.85006 \cdot 02$
$.80 C 0 \mathrm{0}+02$

.9000 . 0

.80001 .02

.89001 .02

$.9100 \mathrm{r} 0 \mathrm{O}$

$.92001 \cdot 02$

.98001 .02

$.10001 \cdot 03$

.10101 .03

.10201 .03

-1130t.03

$-11108.03$

-10001.03

$11000 \cdot 05$

$-11608.03$

-11sor.03

$\therefore 0306 \cdot 03$

.10200 .05

$.20201+r 3$

.21606 .03

.12601 .03

$\because 12600.03$
.23600 .01

lowse iol

POO0E • 0 I

$.8000 \mathrm{E} \cdot 01$

$90 m \mathrm{~m}$ ? 1

$\$ 000 \mathrm{E}+01$

$.0000 \cdot 01$

$.25006+01$

$.25006 \cdot 01$

$.25006 \cdot 01$

$.2500 E \cdot 01$

$.23006 \cdot 01$

$.23006 \cdot 01$

7000 - 01

.2500E +01

$.25006 \cdot 01$

$23000^{\circ} 01$

2500 • 01

$700 \mathrm{NE} \cdot \mathrm{CI}$

.5000 E 00

$.50006 \cdot 00$

. 3000 - 00

$\$ 500 \mathrm{r} \cdot 00$
$\$ 000 \mathrm{P}$

$.1250 \mathrm{+}+0$

$-1250 \varepsilon+\infty 0$

$.1250 E \cdot 00$

$.4623 E+01$

- rooce+01

.0373E.01

$.1625 \mathrm{E} \cdot 01$

$.025 \mathrm{0} \cdot 01$

$.60256 \cdot 04$

$.12506 \cdot 02$
$.12506 \cdot 0$ ?

$.60256+0$ r

.70006 +01

$.70001 \cdot 01$

$\begin{array}{r}.35006 .01 \\ \hline\end{array}$
$.2360 l .0$

$.1663 \mathrm{E}+02$

.0000 * J

$.6000 \mathrm{E} \cdot 0$

AnMMF +nI

.6000E 01

$.6000 \mathrm{t} \cdot 01$

$.7000 \varepsilon+01$

As00e +o

$.5000 E^{\circ} 00$

7ONOE 09

$55000 \% 01$

$.5000 \mathrm{E}+00$

$.6500 E \cdot 01$

SO00E $\cdot 00$

$.7000 \mathrm{C} \cdot 01$

.65001 .01

s000 00

6.001 .0

-12501.00

$1350 \cdot 00$
-1.306 .00

1; $>0$.

$1250 \mathrm{E} \cdot 00$

- $30001 \cdot 01$

-3000 0

.40256 .01

-5250e-0

- $4625 E .01$

iocre.

. 7070 - 0

$.1008 \cdot 0$

$.12508 \cdot 02$

$-12506+52$

$.7000+01$
$.55000+01$

-

$.5500 t^{\circ} 0$
$.3162 E \cdot 0$

-3142e.0

$31626+0$
$-310<2.0$

.316260

$.31622+01$

31626.01

$.31621 \cdot 3$

.31628001

J142r.01

$.31622+0$

$.3162 E \cdot 01$

$31622+n$

$31626 \cdot 01$

$.31626+01$

$.3162 \mathrm{0}+01$

- $3162 E+01$

$.31622 \cdot 01$

316250

-3162 $6 \cdot 01$

- $31626+01$

$3162 E+01$
$.3162 E+01$

$3162 E \cdot 0$

$.31622+01$

.3162E.01

$.31626+0$

.31626 .01

$.31622 \cdot 09$

$31+2 E+01$
$3162 E \cdot 01$

.31626 .01

$-31622.09$

.31621 .0

31621.0

$.31621 \cdot 0$

$31+2 E+01$

$.3162 k \cdot 01$
$.3162 E \cdot 01$
$.0609 E+01$ - $0009 \mathrm{r}$ .6800 E 01

$.3200 E+c 2$

$.1300 \mathrm{E}+02$

.20006 .02

$\therefore 12006 \cdot 02$

.4000E-01

$.40006+01$

$.6000 E \cdot 09$

- $6000 \mathrm{C} 01$

$.12006 \cdot 02$

$.12006 \cdot 02$

$1200 \mathrm{coz}$

-20J0E-02

. 2000 .02

$.2000 \mathrm{E} \cdot 02$

.13006 .02

$-13006.02$

.$\$ 1006.02$

$\$ \$ 100 \mathrm{H} 02$

$.51001 \cdot 02$

.$\$ 000 \mathrm{E} \cdot 01$

.12001 .02

$.2005 t \cdot 02$

.13 OUE.02

$.51002 \cdot 02$

.48001 .02

$.2673 \mathrm{0} \cdot 03$

.15968 .02

.15046 .02

.15946002

.11865 .04

$.1505 \mathrm{E}^{-03}$

$.2673 E \cdot 03$

.1188E 04

$.43206+06$

$.12906 \cdot 05$

- 6800 - 02

- $4800 \mathrm{E}+02$

$.68006+02$
$.6800 \cdot 02$
$.4000+02$

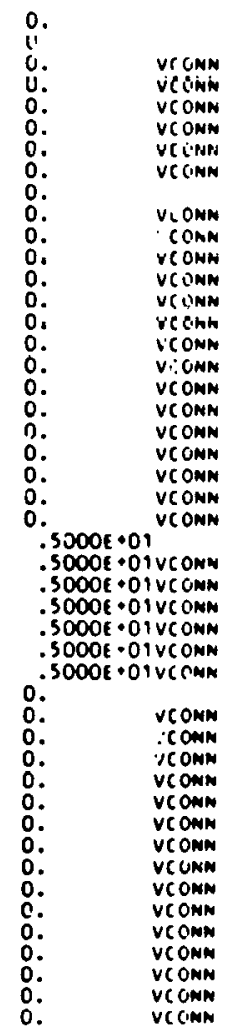


TAP-A INPUT DATA (Cont'd)

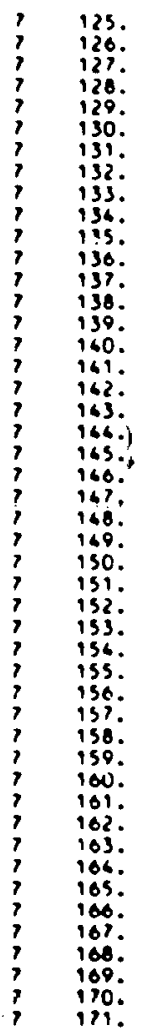
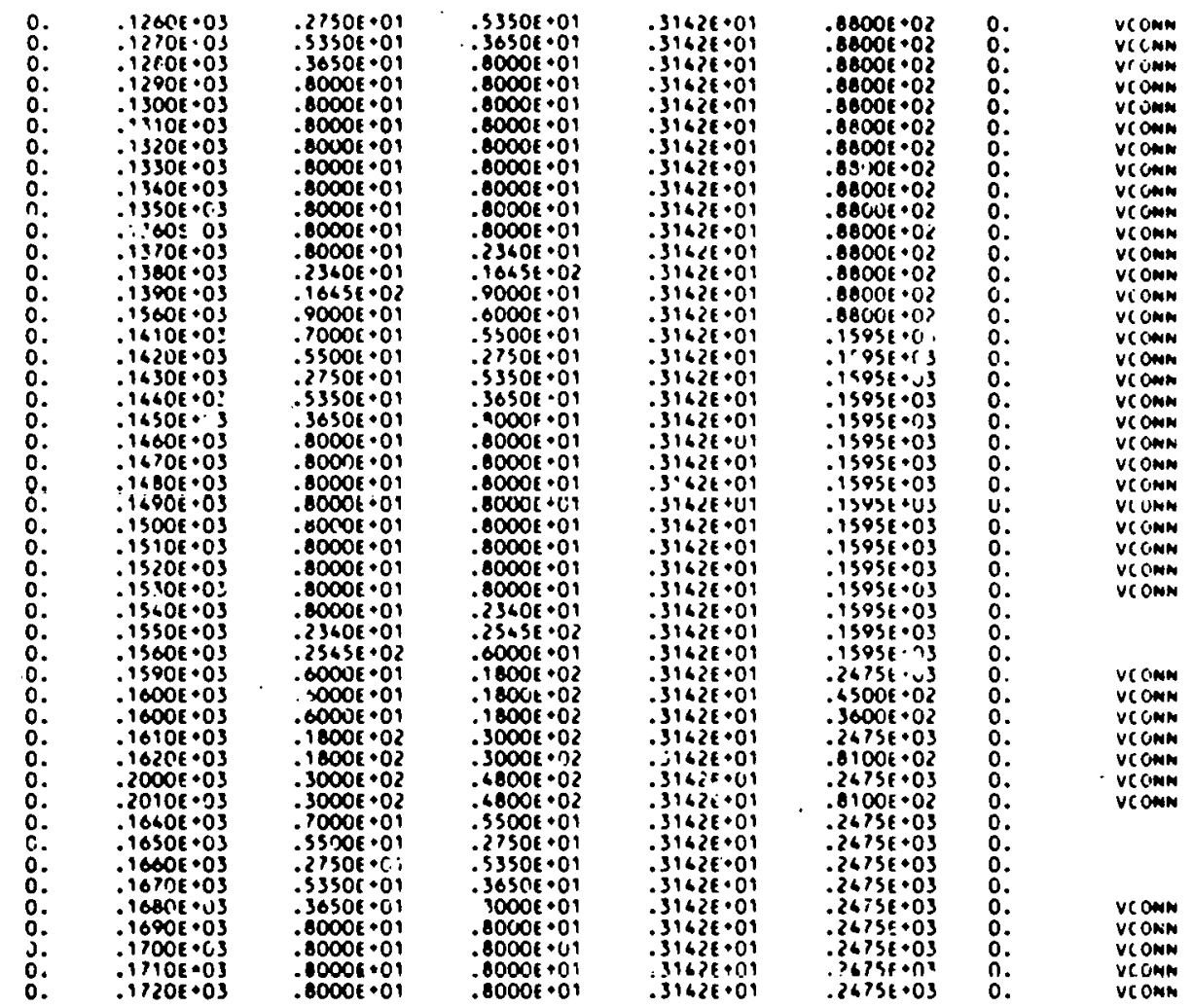

.316280 31621 $-3162501$ 316? :31622:01 31621.01 -31626.09 उ162 316ivol $.31625 \cdot 09$ 31028.01 :\$1628.01 :31628.09 $31,421 \cdot 09$ 31628.01 :31628.0 $31628 \cdot 01$ :31628.01 31628.09 31625.01 :31628.01 :31628.01 .$\$ 1421 \cdot 0$ 316z: $31622 \cdot 0$ :3162t.01 .31621 .01 :31622:09 31021001 31621.01 $3122 \cdot 0$ 31362100 31221.01 $31621 \cdot 01$
$316<01$
.24758 .03 .26755105
.26756003 .26596 .03 .26756.03 .24351.03 .2635 . 03 .2455E.003 $.26751 \cdot 05$ -1188t.06 i11881.04 - 11ner. Os 11886.04 $-11801.04$ $\rightarrow 11801.04$ 911801.06 $.11801 \cdot 04$ .11806 .04 11881.04 11901.04 -1188t.04 $11981 \cdot 04$
$-11001 \cdot 04$ $.11901 \cdot 04$ 11801.04 $\because 11001.04$ .10631 .04 .01001 .02 .63201 .04 .43201 .04 .4320e.06 -43208.04 .43208 .04 .4320e.06 .4320e.04 .63201 .04 .43201 .06 $.43201 \cdot 04$ $\because 3206.06$ .43201 .06

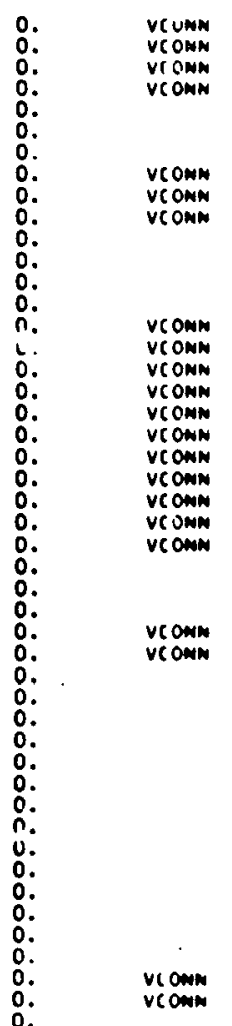


TAP-A INPUT DATA (Cont'd)

\begin{tabular}{|c|c|c|}
\hline 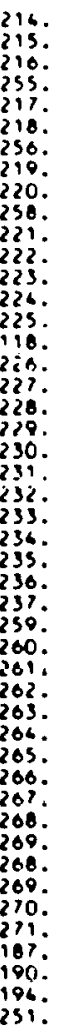 & $\begin{array}{l}0 . \\
c: \\
0: \\
0: \\
0: \\
0: \\
0: \\
0: \\
0: \\
0: \\
0: \\
0: \\
0: \\
0: \\
0: \\
0: \\
0: \\
0: \\
0: \\
0: \\
0: \\
0: \\
0: \\
0: \\
0: \\
0: \\
0: \\
0: \\
0: \\
0: \\
0: \\
0: \\
0: \\
0: \\
0:\end{array}$ & 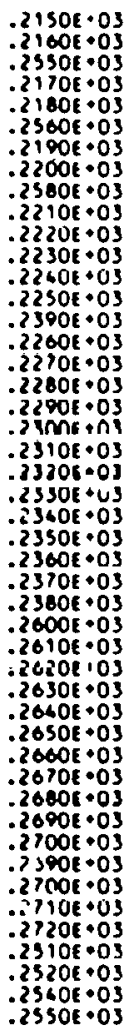 \\
\hline
\end{tabular}
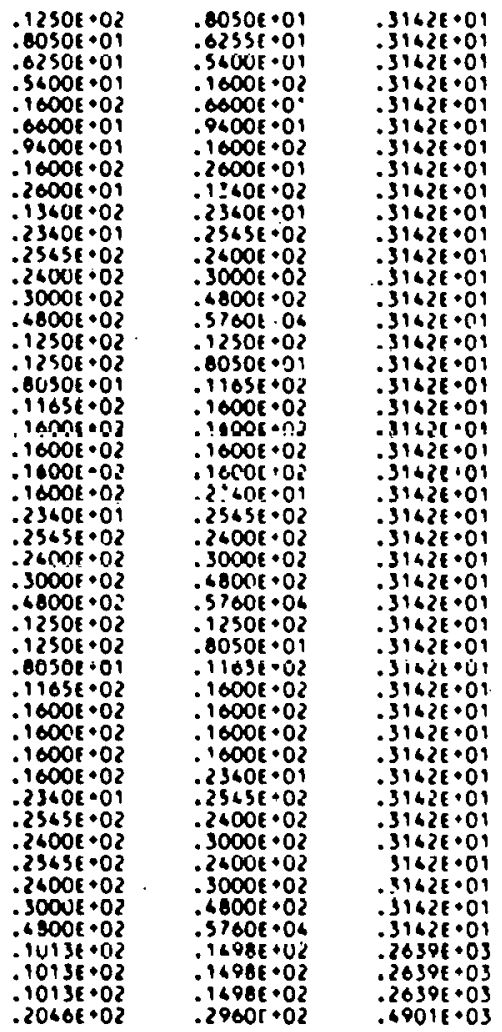

$.20666+0$

\begin{tabular}{|c|c|c|c|}
\hline 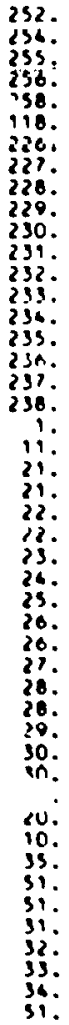 & $\begin{array}{l}0 . \\
0 . \\
8: \\
0: \\
0: \\
0: \\
0: \\
0: \\
00 \\
0: \\
0: \\
0: \\
0: \\
0: \\
0: \\
0: \\
0: \\
0: \\
0: \\
0: \\
0: \\
0: \\
0: \\
0: \\
0: \\
0: \\
0: \\
0: \\
0: \\
0: \\
0: \\
0: \\
0: \\
0: \\
0: \\
0 .\end{array}$ & 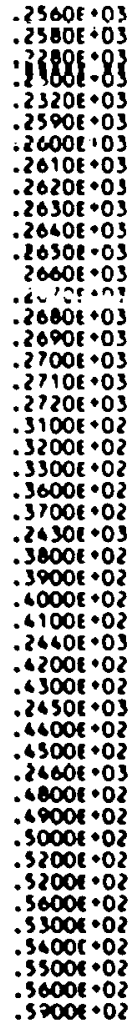 & 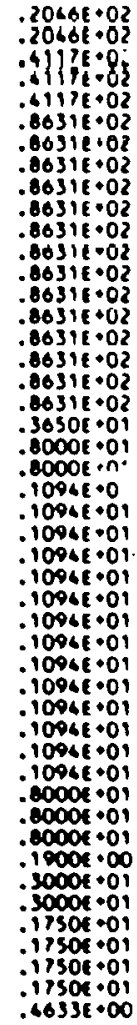 \\
\hline
\end{tabular}

$-39005.03$ $.0087 \mathrm{n}+0 \mathrm{z}$ $.0062 t=02$ .15021 .0 -19021.03 .15026 .03 $-1592100$ $.1592 E+03$ - Isqre -us :1S92E.03 .13926 - OJ $-1592 \mathrm{E}+03$ .15021 .03 $.13922+03$ -1750e.01 $.17506+01$ -irsoe+01 $.18496 \cdot 00$ .10698 .00 .18496 .00 .18698 .00 .18698 .00 $.18496 \cdot 00$ .18698 .00 $\therefore 1698 \cdot 00$ $.18698 \cdot 00$ .18698 .00 .18498 .00

$.18498 \cdot 00$

$.18498 \cdot 00$

$.18751+00$

$.18751 \cdot 00$

$.43611+00$ .53500 .01 $.50001 \cdot 00$ $.50001 \cdot 00$ .50001.00 $\$ 0001 \cdot 00$ $\$ 500 \mathrm{E} \cdot 00$ .36111 .00

\begin{tabular}{|c|c|}
\hline 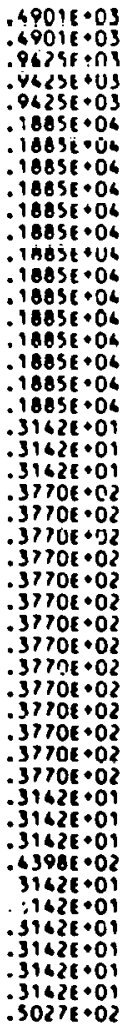 & 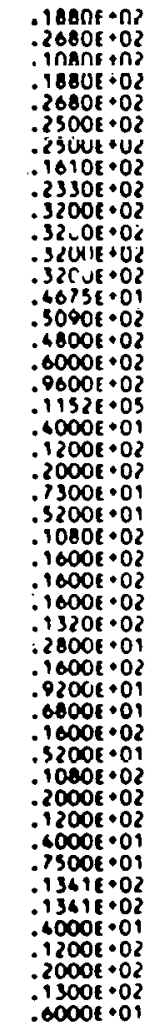 \\
\hline
\end{tabular}

$.16621 \cdot 05$ $.10421 \cdot 09$ $.16+21.05$ $.10+21.05$ .10421 .05 $.1642 t \cdot 05$ $.16421 \cdot 05$ $.16621 \cdot 05$ $.10621 \cdot 05$ .16421 .05 .10421 .05 .10621 .05 $-10421005$ . 10621.05 .6750e.05 .07301 .05 .orsor.0s $8 \% 50$ los .6 isnt.0s - ofsor-os - orsor.os . orsor.os $.07501 \cdot 05$ - 67sor.os .07501 .05 .42861 .00 .62341 .00 - 628 tive .62841 .06 .62861 .04 .62865 .06 .62868 .00 - A28at+0o - $62846 \cdot 06$ . $.6 .386 \cdot 06$ $.62866 \cdot 0 A$ 6286600 -10808. .10008 .02 $.1080 \%+02$ 
TAP-A INPUT DATA (Cont'd)

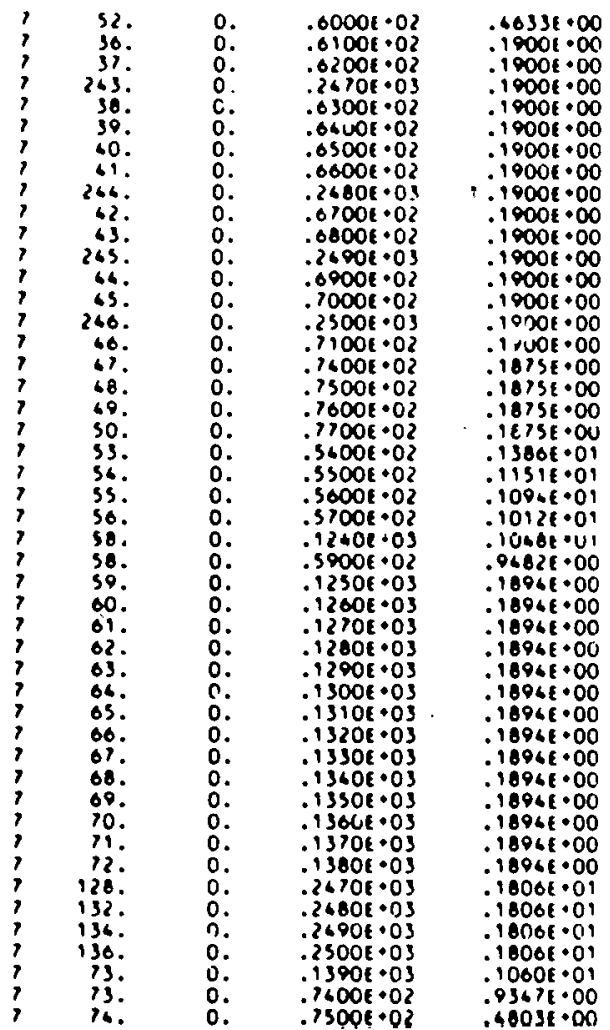

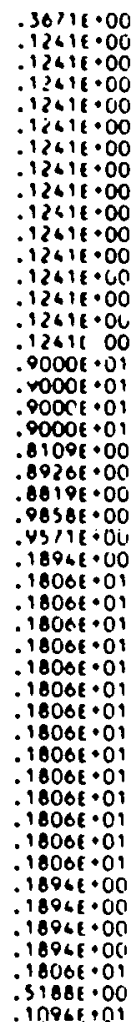

.89268 .00

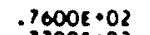

$.71001 \cdot 02$

$.7600 E+02$

$.77006 \cdot 02$

.81006 .02

$.82006 \cdot 02$

$.8400 \mathrm{0}+02$

$.8500 \mathrm{\theta}+02$

.80006 .02

$.8800 E \cdot 02$

$.8900 \mathrm{O}+02$
$.9000 \mathrm{0} \cdot 02$

.91006 .02

$.92006 \cdot 02$

$.10806 \cdot 03$

$.10906 \cdot 03$

.94006 .02

$.05006 \cdot 02$

.90006 .02

.97001 .02
.99001 .02

$.99001 \cdot 02$

$.10006 \cdot 03$

$.10101+03$

.10201 .03

$.10306 \cdot 03$

$.10401 \cdot 03$

$.10506 \cdot 03$

$.10601 \cdot 03$

.12201 .03

$.1230 t \cdot 03$

$.12601 \cdot 03$

$.11208 \cdot 03$

.11008 .03

$.11406 \cdot 03$

$\because 11508 \cdot 03$

$.11001 \cdot 03$

.11700 .03

.1400 .03

isioe.03

-16208.03

.16301 .03

.1460 .03
.16306 .03
.81096 .00

.89261 .00

$13806 \cdot 0$

$-13806 \cdot 01$

-13806.01

-11sic.0

i1sie.0

.10961 .09

$1096(101$

.10126 .01

$10121 \cdot 0$

$-10121 \cdot 01$

11096.01

$11091 \cdot 01$

$13800 \cdot 01$

$\because 1311+01$

$10001 \cdot 01$

$.13861+0$

-11516.01

$10948 \cdot 01$

$1068 c \cdot 01$

sime.0o

$10616 \cdot 01$

.27038 .01

$.36136 \cdot 00$

$.36158+00$

.31336.01

$.10136 \cdot 02$

. $31036 \cdot 01$

.10136 .02

$.20468 \cdot 02$

.10618 .01

10616.01

$.2172 \mathrm{0} \cdot 01$

. $31726 \cdot 01$

.21736.09
$.11511 \cdot 01$

$-13876+01$

:1387e.01

$.8109 E+00$

$.6109 \varepsilon+00$

$.81096 \cdot 00$

$.89206+00$

$.89261 \cdot 00$

$.8619 E \cdot 00$

$.8819 E+00$

$.8819 \mathrm{0} \cdot 00$

$.9 B 58 E+00$

$.98586 \cdot 00$

$.98586 \cdot 00$

$.3603 \mathrm{E}+00$

$.36036 \cdot 00$

$.8109 t .00$
$.8926 t .00$

$.89261 \cdot 00$

$.92691 \cdot 00$

$.83066 \cdot 00$

$.89268 \cdot 00$

$.9268 \cdot 00$

$.03061 \cdot 00$

$48796 \cdot 10$

.23396 .01

.27226 .0

.95711 .00

.95111 .00

.16631 .01

16986.02

.27226 .01

.16901 .02

.29001 .02

.23391 .01

.23398 .0

$.23396 \cdot 0$

.23306 .01

$.23398 \cdot 01$

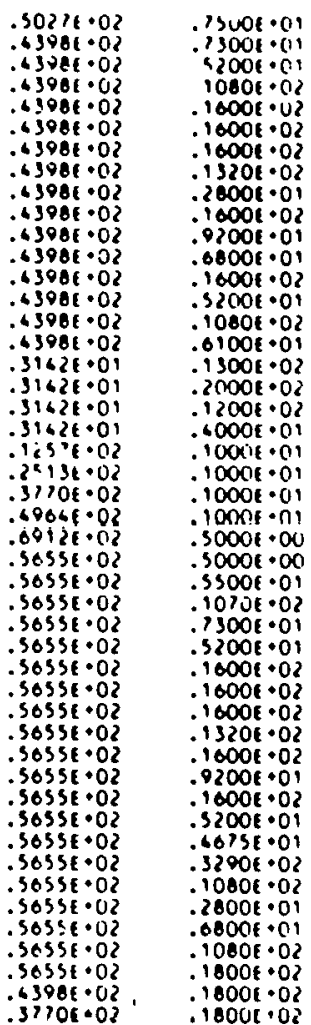

$.200 x+1601120 \mathrm{mon}$

sonklf + (11)

jocke - ortione

\$0001 0 Oll cima

3000e . $011 \mathrm{lmm}$

3000 - 31 l comm

300ue - 011 rima

- 3000t. Or lina

- soder or cinm

soor tr romn

ir coe +oi c cma

- Jinue - ol coma

- scoper orcona

cocor or cuma

conoe - oircoma

- toocit - citcoma

0 .

ac Cown

ac conn

h ONA

accinh

aconn

nc ONM

HC ONN

ncoms

nCONM
$.25136 \cdot 02$

$.25136 \cdot 02$

12376.02

12571.02

.12576.02

.25136 .02

25131.02

37101.02

37101.02

$31101 \cdot 02$

.49061 .02

.49061 .02

$.02836 \cdot 02$

$.02831 \cdot 02$

.02821 .02

12578.02

.23131 .02

.4904602

.12578 .02

.25136 .02

$.0006 \mathrm{0} .02$

$.62836+02$

$.0912 k \cdot 02$

.81006 .02

$.11396 \cdot 03$

$.09126 \cdot 02$

$.0012 \mathrm{E} \cdot 02$

$.09126 \cdot 02$

$.1308 \mathrm{*} \cdot 03$

$.26396 \cdot 03$

$\because 11396 \cdot 03$

$.26306 \cdot 03$

$.69018+03$

$.0108 \mathrm{0} \cdot 02$

$.81686+02$

$.81686 \cdot 02$
$.81686 \cdot 02$

.81086 .02

$.81686 \cdot 02$
$.8168 t \cdot 02$
$.18001 \cdot 02$

$18001+02$

$.18000+02$

$.50006 \cdot 01$

$-14006 \cdot 02$

$-1300 \mathrm{0} \cdot 02$

S000E 01

14006.02

30006.01

$14006 \cdot 0$

$13006 \cdot 02$

$.50000 \cdot 0$

14006.02

$.1300 \mathrm{\cdot} 02$

$.50005+01$

$-16006 \cdot 02$

.13000 . 02

$10006 \cdot 0$

- 10006.01

$.10006 \cdot 01$

$.25006 \cdot 00$

$.25000^{\circ} .00$

.25000 .00

$.25001 \cdot 00$

$.2500 \mathrm{H} \cdot 00$

25001.00

$.25001 \cdot 00$

.92501 .01

.16001 .02

.18751 .02

.15551 .02

.92501 .01

.92501 .0

.25001 .02

$\because 6000.02$

$\because 11008 \cdot 02$

$.55008 \cdot 01$

$.1070 \mathrm{0}+02$

$.73006 \cdot 01$
$.16006 \cdot 02$

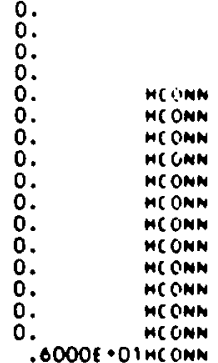
.6000e-0ín $.00008+01$

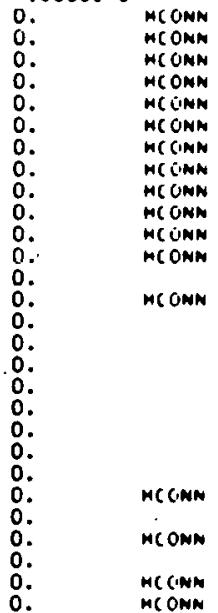


TAP-A INPUT DATA (Cont'd)

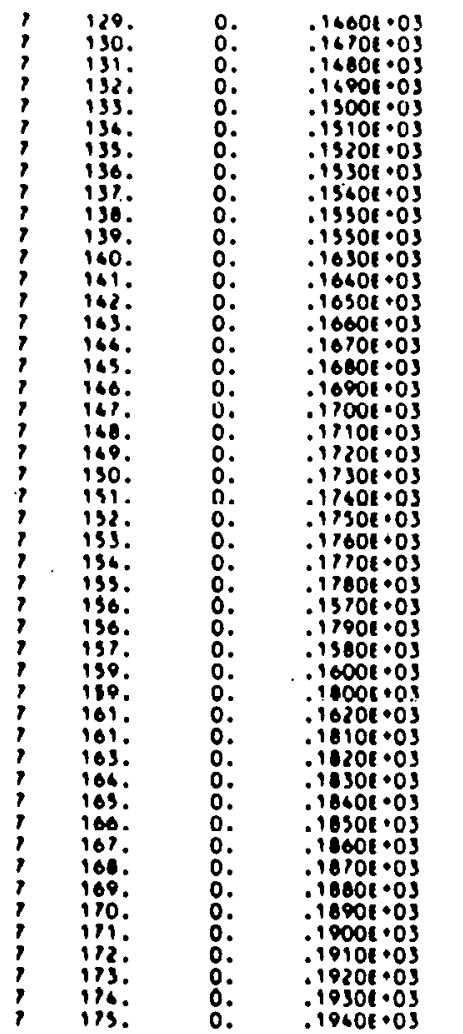

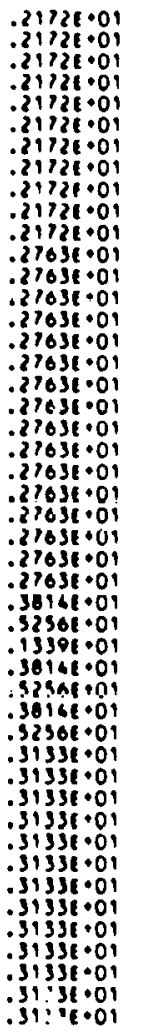

\begin{tabular}{|c|c|}
\hline 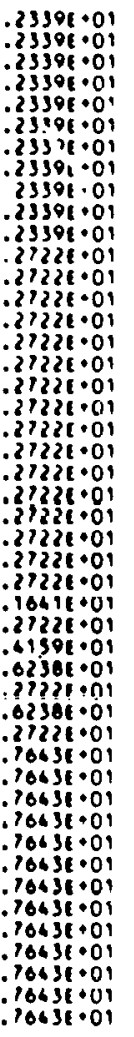 & 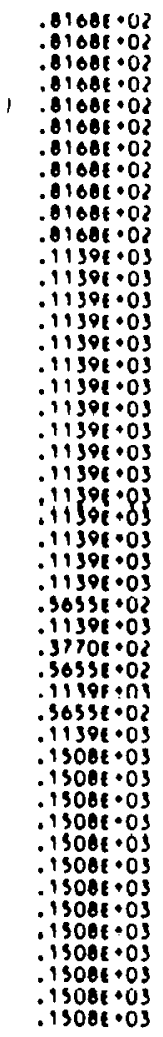 \\
\hline
\end{tabular}

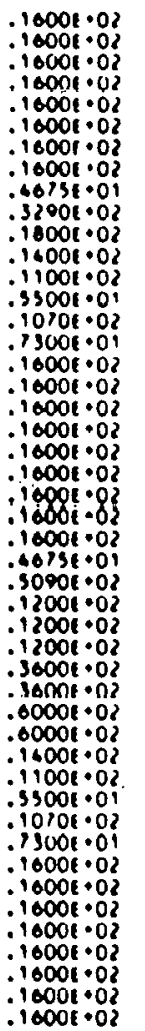

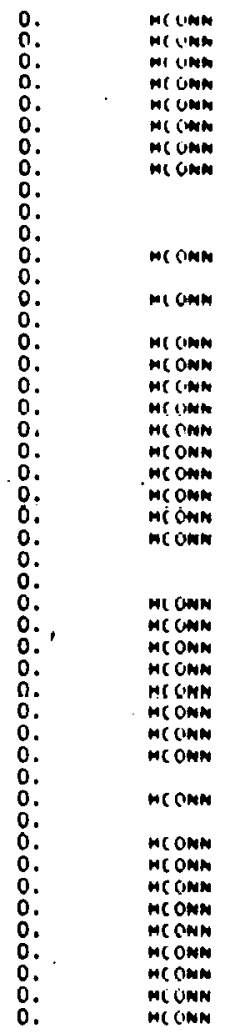

.19506 .03 .19006 .03

$: 19801.03$

i19uotus

10001.03

.20201 .0

.20200 .03

.20301 .03

.20400 .03

.20401 .03

.80301103

.20301 .03

.20601 .03

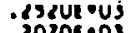

.20701 .03

.20001 .03

istot.03

.20001 .03

.21001 .05

.21100 .03

.21701 .03

$.20101 \cdot 03$

.21001 .03

.21501 .03

$.21101 \cdot 03$

$-21 \mathrm{col} \cdot 03$

.21001 .03

$.22001 \cdot 03$

$.22109 \cdot 05$

$.22301 \cdot 03$

$.22301 \cdot 03$

- licot-os

$.22001 \cdot 03$

.22109 .03

.22\%01:03

$.23001 \cdot 03$

.31100+03

.23208 .03
.31336 .01

jij]e.

-jiss:

.31338 .01

$.10111-02$

-10136.02

.10131 .02

$: 10135.02$

4093302

.10131 .02

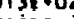

ivise.ve

.10196 .02

.10138 .02

$: 10138.02$

$: 10138 \cdot 02$

$.1013 e+02$

.10131 .02

-16131.02

.20608 .02

.20660 .02

.20406 .02

.20468 .02

.20606 .02

.30401 .02

.20061 .02

.20601 .02

80661.02

$.20466+.02$

c1118.0?

- $1111 \mathrm{cos}$

-111!1!0?

.611).02

ㄴ11!ro?

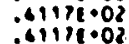

Tous 0

.10031 .0

rousivu

.16631 .09

.16908 .02

- 14901002

$\$ 16981.02$

.160810 a

(16981.'L?

16001.02

.16981 .0 ?

- intoivel

iliget.o?

16981.02

.149010 ?

:16901.02

16901.02

.16901 .02

.16981 .02

.02300102

.29001 .02

.20001 .02

.29001 .02

28001.02

.29001 .0

$.20001+02$

.20001 .02

29001.02

29001.02
.29001 .02

.00021 .02

$.0042 \cdot 02$

$.0028+02$

$.0012+02$

.00421 .02

.00628 .02
.60021 .02
$-15008 \cdot 03$

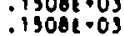

.15080 .03

- 1suge-ug

-

.36jpr.0J

.20390 .03

$.26391 \cdot 03$

$.26398+03$

.2019 -03

.26391 .03

.10316 .03

.26398 .03

.2630103

$.2039 \mathrm{E} \cdot 03$

.26391 .03

.26391 .03

$.70391 \cdot 03$

.2039103

.56556 .02

.401E.03

:4018.03

.4011 .03

-401E.03

:4011.03

.4011.03

.4011.05

49011.03

¿4011.03

.94231.03

.96251 .03

.96251 .05

-96251.03

.06251 .03

.96251 .03
.96251 .03

$.1000 i \cdot 02$

.60756 .01

12001.02

10001.0?

$.16001 \cdot 02$

j5001.0

10701.02

.13001.01

$\$ 2001 \cdot 01$

$-1000110$

13201.02

-1001 : 0

16001.02

$\$ 2001 \cdot 01$

.10001 .02

.66751 .01

$30001 \cdot 02$

48001.02

$.96001 \cdot 02$

.96001 .02

$23001 \cdot 02$

.12301 .02

32001.02

$.13208 \cdot 02$

$.32008 \cdot 01$

.4015 .01

$30 \% 01.02$

-4000 .02

$.0002+02$

$.29001 \cdot 02$

.16108.02

$.13500 \cdot 02$

13201.02

.32001 .02

$.32006 \cdot 09$
.60756 .09

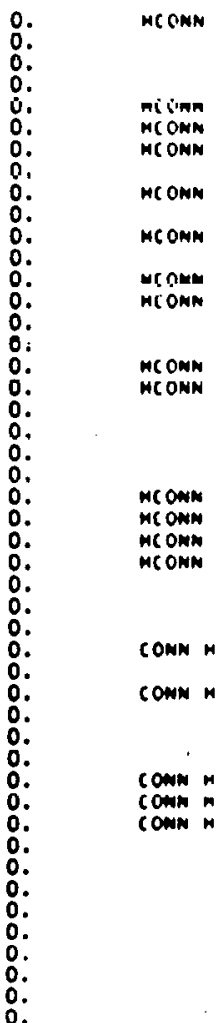


TAP-A INPUT DATA (Cont'd)
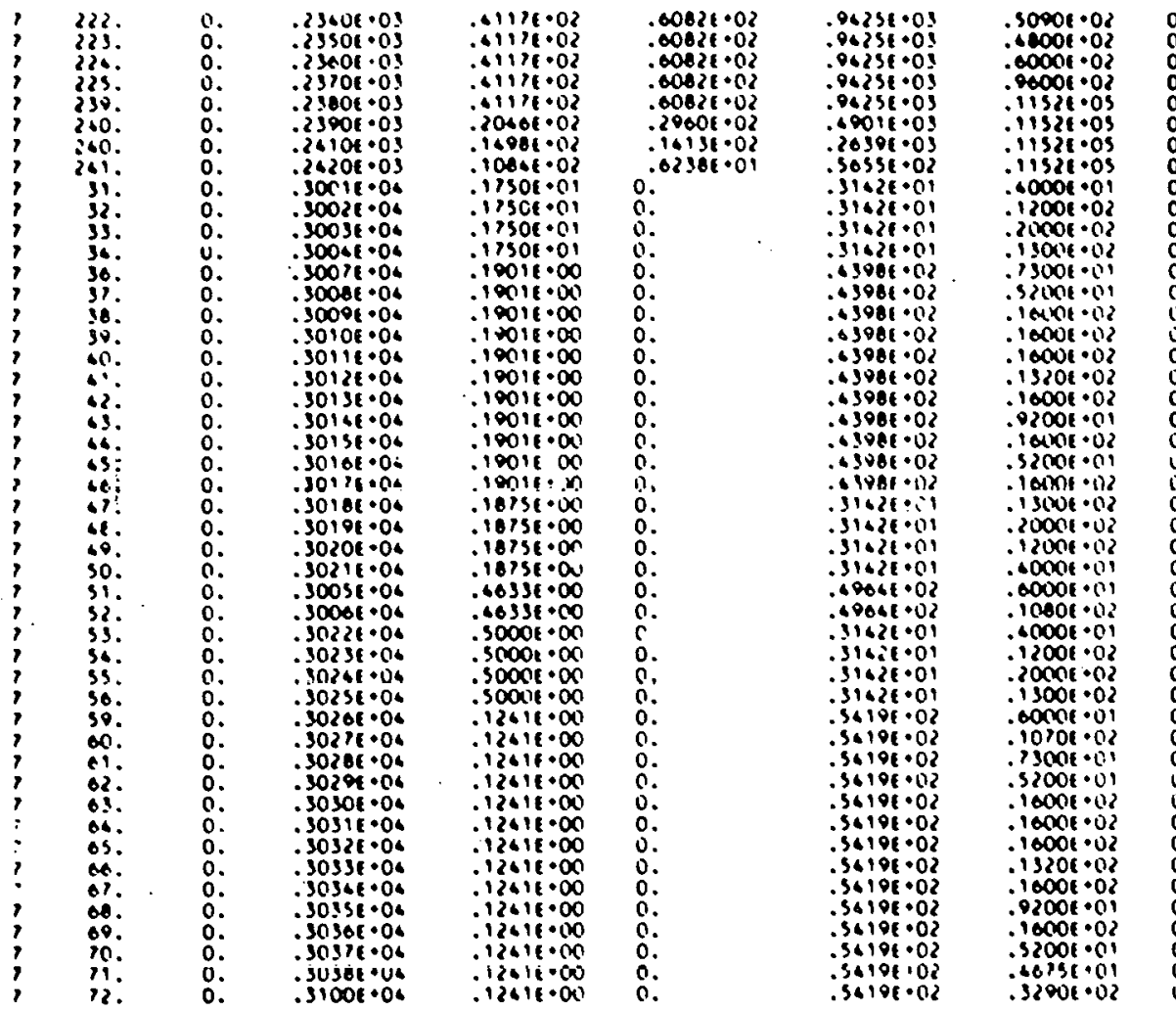

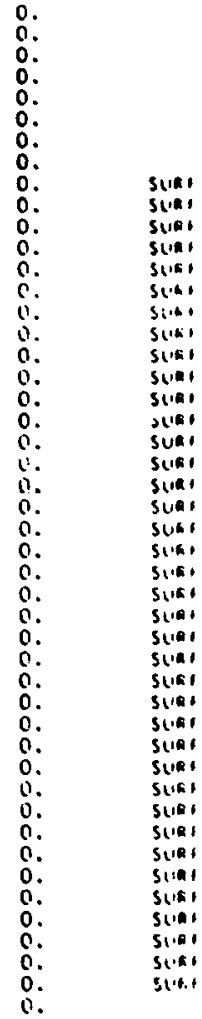

\begin{tabular}{|c|c|c|}
\hline 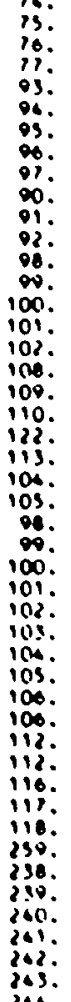 & $\begin{array}{l}0: \\
0: \\
0: \\
0: \\
0: \\
0: \\
0: \\
0: \\
0: \\
0: \\
0: \\
0: \\
0: \\
0: \\
0: \\
0: \\
0: \\
0: \\
0: \\
0: \\
0: \\
0: \\
0: \\
0: \\
0: \\
0: \\
0: \\
0: \\
0: \\
0: \\
0: \\
0: \\
0: \\
0: \\
0:\end{array}$ & 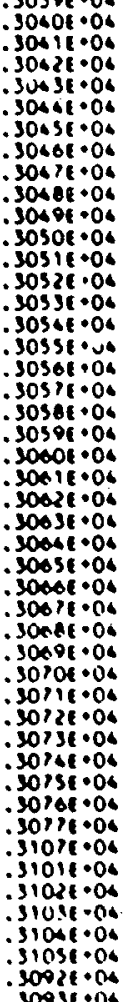 \\
\hline
\end{tabular}

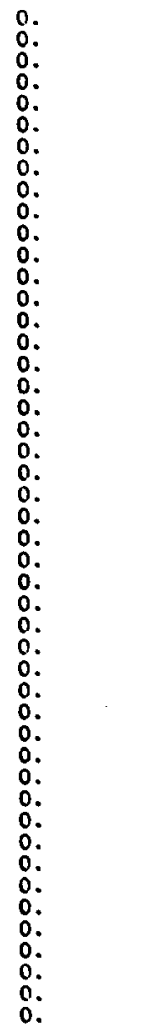

.31021 .01

.31621.09

उ16210

- Binze 01

-31626.01

-316ze-01

$.31628 \cdot 09$

.02836 .02

.02836 .02

3)625.01

-31625.01

islaze 0.

.eccos -0?

64606.02

.0460.02

.3147e.01

$-31626.01$

-31626.01

3167601

31626.01

$316 z e+01$
31628001

:\$16ze-0

.31626 .01

- 1508 . 03

31621.01
20301.00

31682.00

$31628 \cdot 0$

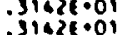

.31628001

-31628.01

.316?e-01

$.31686 \cdot 01$
.4900 .02

$\because 49986 \cdot 02$

$.15001 \cdot 02$

$.20001 \cdot 02$

$.40001 \cdot 01$

.40008

.12001 .02

.20008 .02

.31001 .02

.00000 .01

$14001 \cdot 02$
$113008 \cdot 02$

- iover.01

120001.02
20001.02

$13001 \cdot 02$ .51001 .02

14001.02

iosol.02

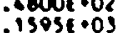

.4001 .0

.15051 .09

.$\$ 0000.02$

.20001 .02

$-31001.02$

.21001 .02

$40001 \cdot 02$
13951.05

-26r5t.03

25000

- 11ser

- $13200 \cdot 0$

1

. o7sot.0s

$.42041 \cdot 0$

. orsor.os

10421.0

- 3201.3

16031.04

.10001 .02

.28001 .02

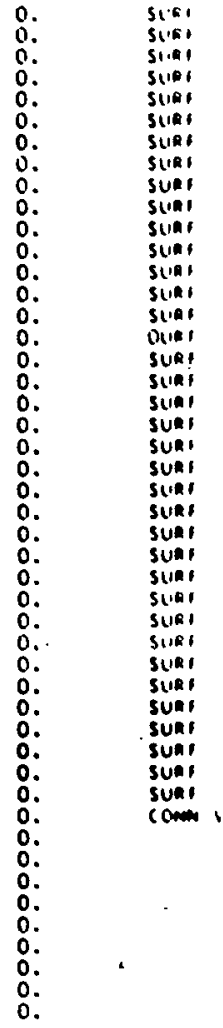


TAP-A INPUT DATA (Cont'd)
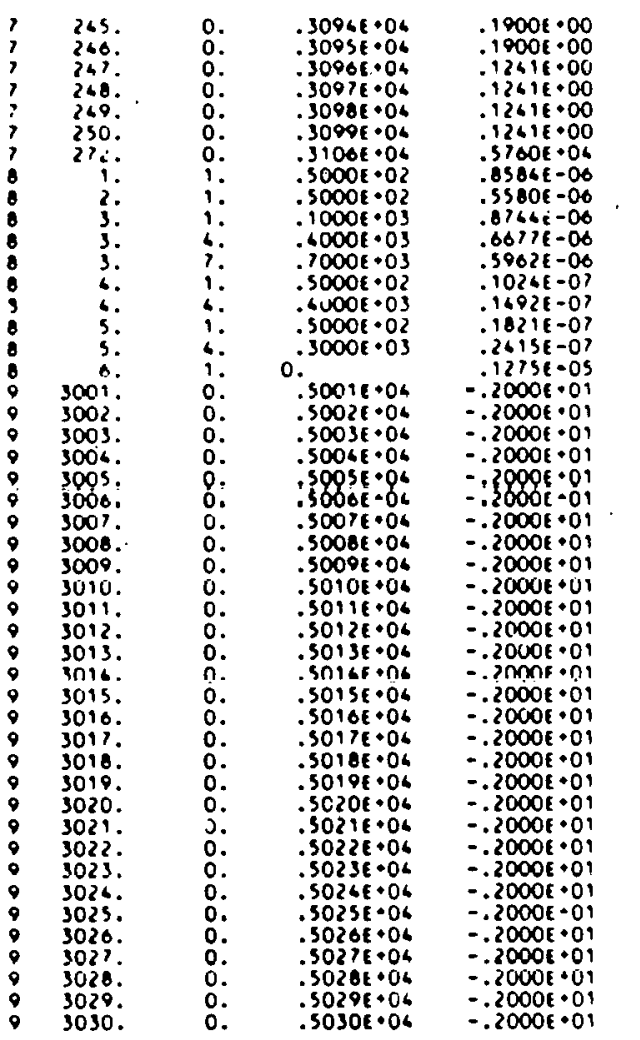

0.
$\vdots$
0
0.
0.

0.

$0.0000 \cdot 03$ . 0000 e
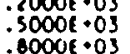

.8000 .

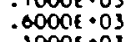

$.1821 \mathrm{E-0}$ ?

$.1215 e-0 s$

$-.20006+01$

$-.20006 \cdot 01$

$-.2000 \mathrm{E} \cdot 01$
$-.2000 \mathrm{E}+01$

$-30006+01$

-.2000 * 01

$-.20001 \cdot 01$

$-.20006 \cdot 01$

$-.2000 E+01$
$-.2000 E+01$

$-.2000 \mathrm{E}+01$

$-.2000 \mathrm{0} \cdot 01$

-

$-.20001 .01$

$-.20006 .01$

$-.2000 \mathrm{E} \cdot 01$

$-.20001 .01$

$=.20001 .01$

$-.20001 .01$

$-.20006 \cdot 01$

$-.20006 \cdot 01$

$-.2000 \mathrm{E} \cdot 01$
$-.2000 \mathrm{~F}$

-2000 . 01

$\because 8000 \mathrm{E}+09$

$-.20006 .01$

$\begin{array}{ll}0.00006 .03 & 0 . \\ 0 . & 0.27006-05 \\ 0 . & 0 .\end{array}$

0 .

0 .

0.

o.

o.

0.

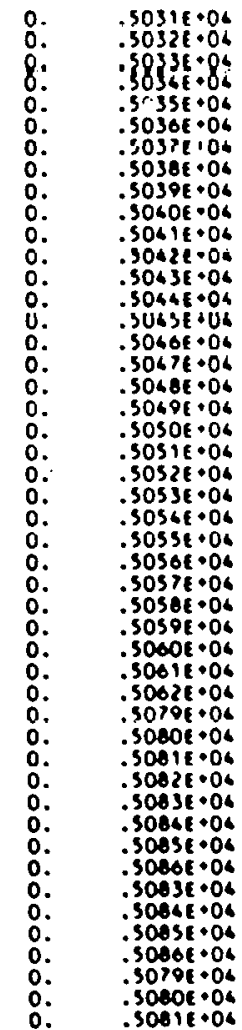

$=20006 \cdot 01$

3031.

$-.38005 \cdot 81$
$-.20005 \cdot 81$

$-2000 \mathrm{E}+01$

$-2000 \mathrm{r} \cdot 01$

$-20001.09$

$-2000 \mathrm{E} \cdot 01$

$\because 2000101$

-20001.01 .

$-2000 \mathrm{E} \cdot 01$

$-.20001 .01$

$-20001.01$

- 20000 e vo

$-20001 \cdot 01$

$-20001.01$

$-20001 \cdot 01$

.20001 .01

$-20001 \cdot 01$

$-.20001 \cdot 01$

$-20001 \cdot 01$

$-20001.09$.

$-2000 \mathrm{-} \cdot 01$

$-.20001 \cdot 0$

$-20001 \cdot 01$

$-.2000 \mathrm{r} \cdot 0$

$-.20006 \cdot 01$

$-.20006 \cdot 01$

$-.2000 \mathrm{E} \cdot 0$

$-.2000 \mathrm{E} \cdot 0$

$-2000 \mathrm{E} \cdot 0$

$-20005 \cdot 01$

$-.20006 \cdot 01$

$-.2000 \mathrm{t}+01$

$\because 2000 \mathrm{E}+0 \mathrm{r}$

$-2000 \mathrm{E} \cdot 01$

$-.20006 \cdot 01$

$\because 20006 \cdot 0$

$\because 1000 \mathrm{e} \cdot 0$

$\because 10006 \cdot 01$

$\because 10008 \cdot 0$

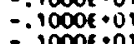

$\because 10006 \cdot 01$

0.
$0:$
$8:$
$0:$
$0:$
$0:$
$0:$
$0:$
$0:$
$0:$
$0:$
$0:$
$0:$
$0:$
$0:$
$0:$
$0:$
$0:$
$0:$
$0:$
$0:$
$0:$
$0:$
$0:$
$0:$
$0:$
$0:$
$0:$
$0:$
$0:$
$0:$
$0:$
$0:$
$0:$
$0:$
$0:$
$0:$
0.

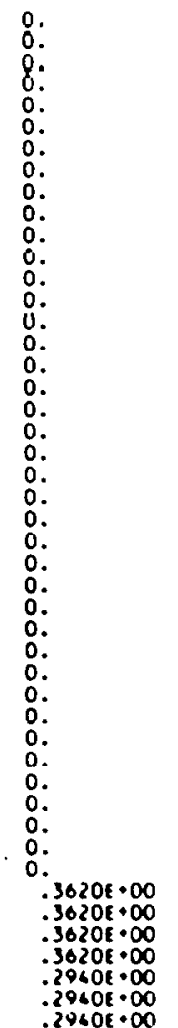

$8:$
$0:$
$0:$
$0:$
$0:$
$0:$
$0:$
$0:$
$0:$
$0:$
$0:$
$0:$
$0:$
$0:$
$0:$
$0:$
$0:$
$0:$
$0:$
$0:$
$0:$
$0:$
$0:$
$0:$
$0:$
$0:$
$0:$
$0:$
$0:$
$0:$
$0:$
$0:$
$0:$
$0:$
$0:$

$.08006 \cdot 01$

$.00806 .02 \quad 0$.

$.28001 \cdot 01$

$.08006 \cdot 01$

$.10806 \cdot 02$
$.02868 \cdot 00$

0 .

$.05061-00$

$.96218-06$
$.7969-00$

$.63586-00$

$.38826-00$

$.30008 \cdot 03$

$.00006 \cdot 03$

0.

$20006 \cdot 03$

$.20006 \cdot 01$

$20206-01$
$.21710-61$

o.

o.

0.

o.

0.

:.

:.

:

:.

0.
0.
0.

:.

o:

0.

o:

0.

0.

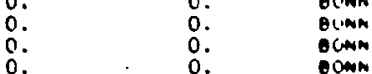

$\begin{array}{lll}0 . & 0.0 & 0 \\ 0 & 0 & 0\end{array}$

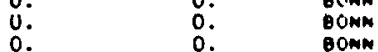

$\begin{array}{lll}0 . & 0.000 \\ 0 & 0.0 & 0\end{array}$

0. $\quad 0 . \quad \operatorname{\theta in}$

o. 0.0 .000

o. $\quad$ o.

o. $\quad 0.00$

: $\quad 0 . \quad \operatorname{limn}$

$0 . \quad 0 . \quad$ ocoun

:. $\quad$ :. gown

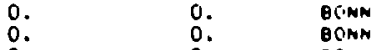

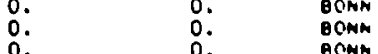

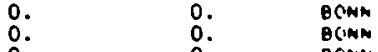

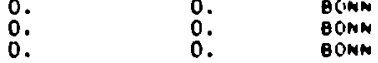

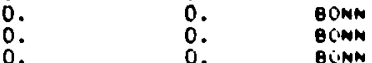


TAP-A INPUT DATA (Cont.'d)
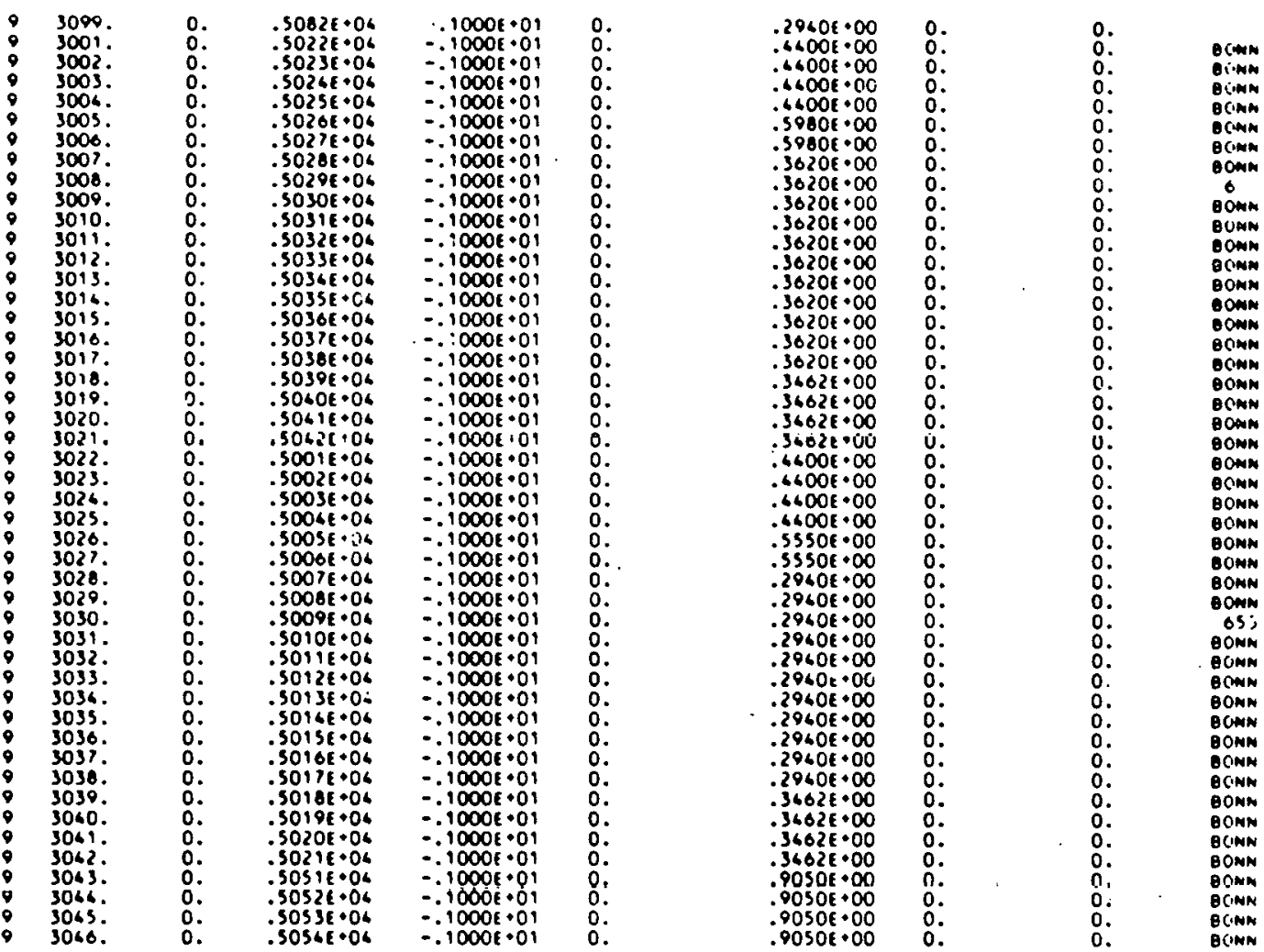

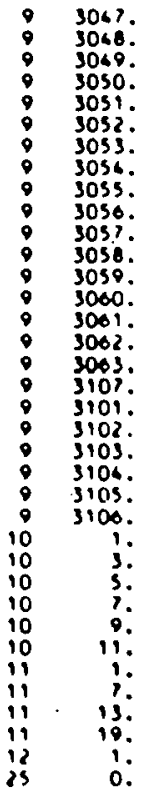
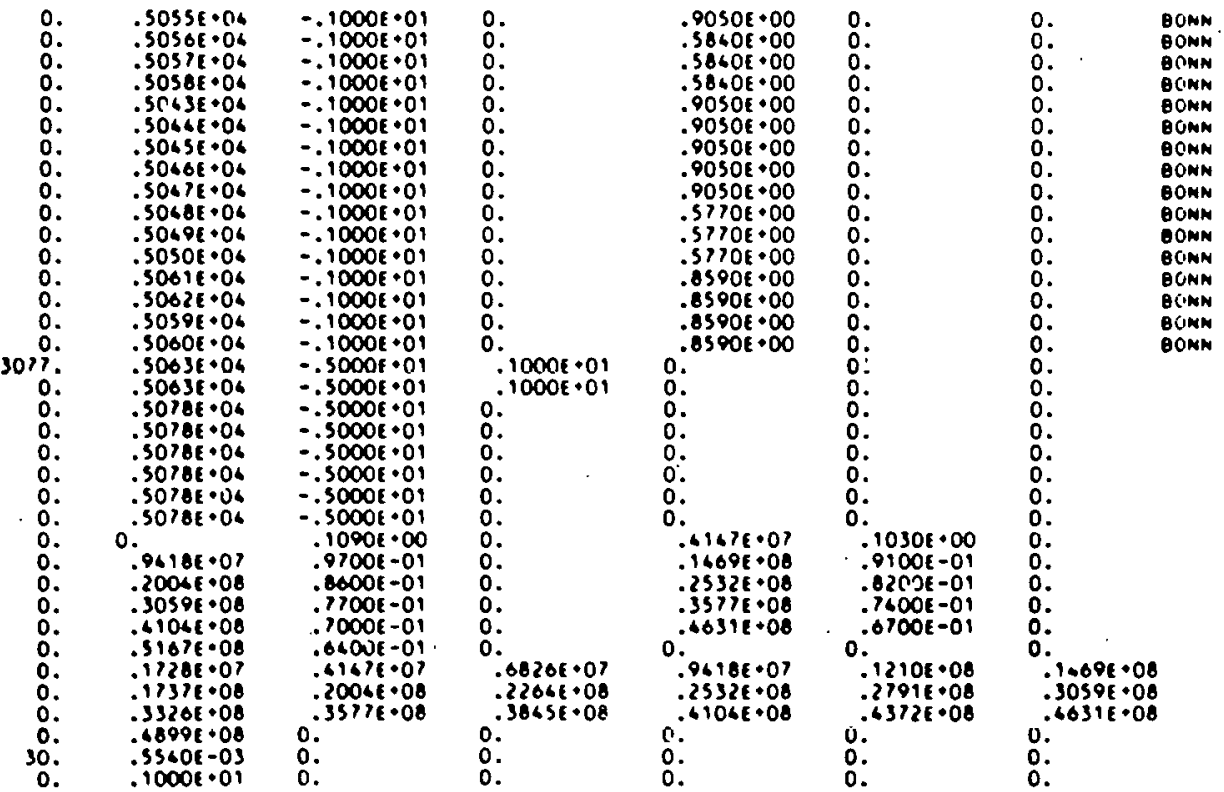
TAP-A OUTPUT

TAP--TRANSIENT AMALYSIS PROGRAM

Darefle mo. S SImulation - Stakt jamuary 12,1970

SPECIFICATIONS

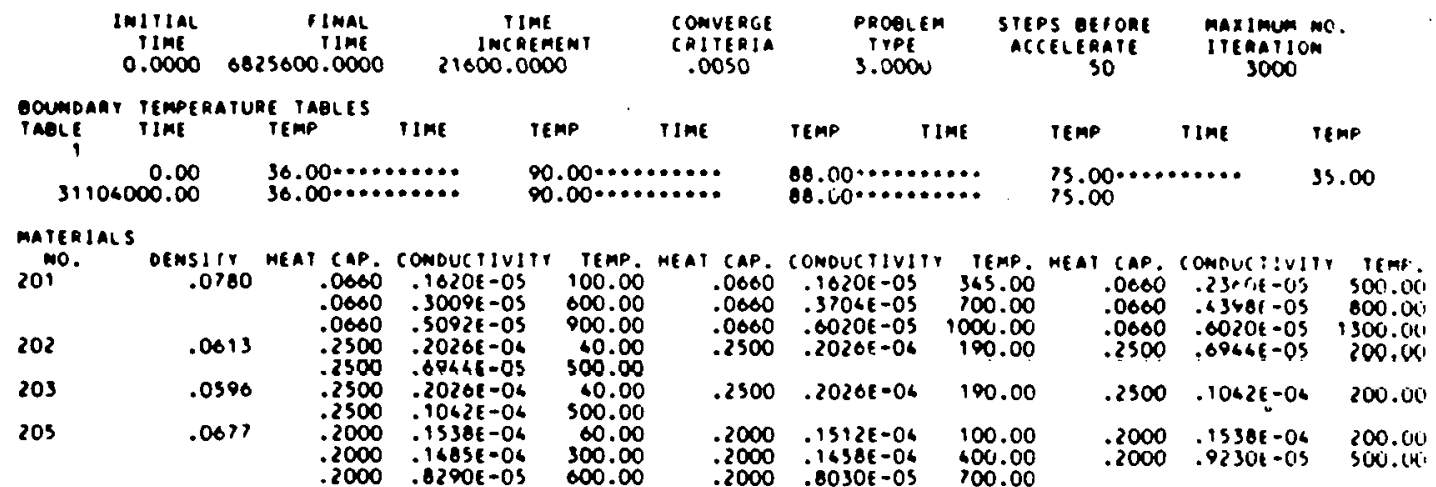

\begin{tabular}{|c|c|c|c|c|}
\hline $\begin{array}{l}226 \\
227 \\
228 \\
229 \\
230\end{array}$ & $\begin{array}{l}.2830 \\
.2830 \\
.0822 \\
.0822 \\
.0600\end{array}$ & $\begin{array}{l}.2000 \\
.1100 \\
.1100 \\
.2000 \\
.2000 \\
.2500\end{array}$ & $\begin{array}{l}.82900 \\
.23150 \\
.33260 \\
.24310 \\
.26310 \\
.20260\end{array}$ & $\begin{array}{l}E=05 \\
E-03 \\
E=03 \\
E-04 \\
E-04 \\
E-06\end{array}$ \\
\hline & $\begin{array}{l}\text { T GENE } \\
0 \text { WNE } \\
1090 \\
1030 \\
0970 \\
0910 \\
0800 \\
0820 \\
0710 \\
0160 \\
0100 \\
0870\end{array}$ & $\begin{array}{l}\text { IOM mu } \\
\text { Tasi } \\
0.0 \\
0.0 \\
0.0 \\
0.0 \\
0.0 \\
0.0 \\
0.0 \\
0.0 \\
0.0 \\
0.0\end{array}$ & $\begin{array}{l}\text { IPLIER } \\
0 \\
000 \\
000 \\
000 \\
000 \\
000 \\
000 \\
000 \\
000 \\
000 \\
00\end{array}$ & $\begin{array}{c}\text { TAQLES } \\
\text { TinE } \\
0.0000 \\
6167200.0000 \\
9417000.0000 \\
16688000.0000 \\
20066800.0000 \\
25395200.0000 \\
30585600.0000 \\
35769000.0000 \\
\$ 1040000.0000 \\
\$ 6310400.0000\end{array}$ \\
\hline
\end{tabular}

$.0640 \quad 0.0000 \quad 51667200.0000$

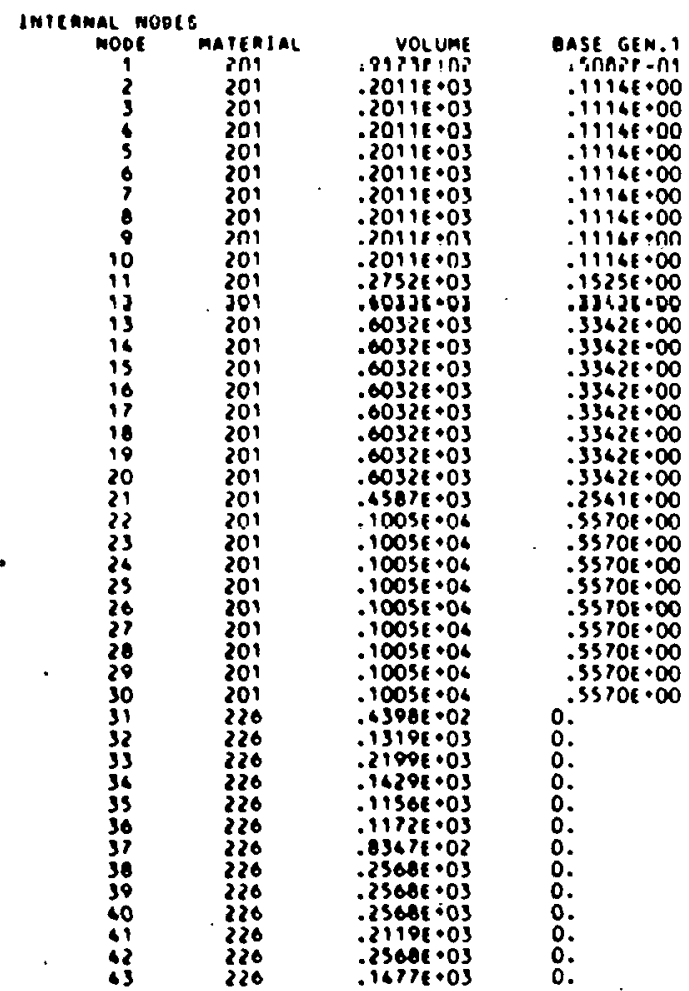

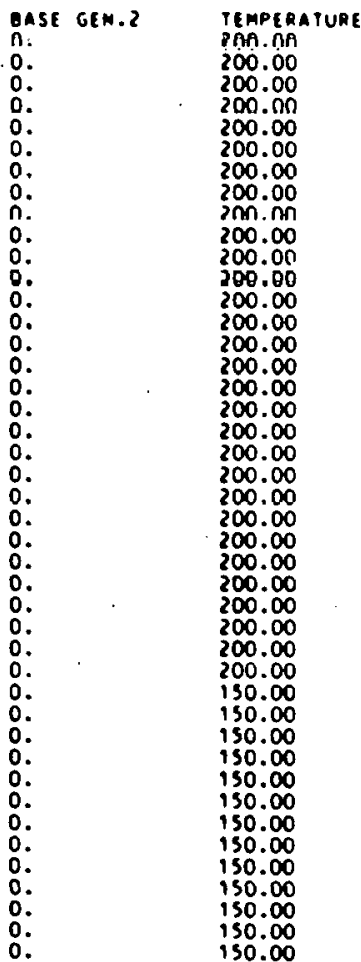




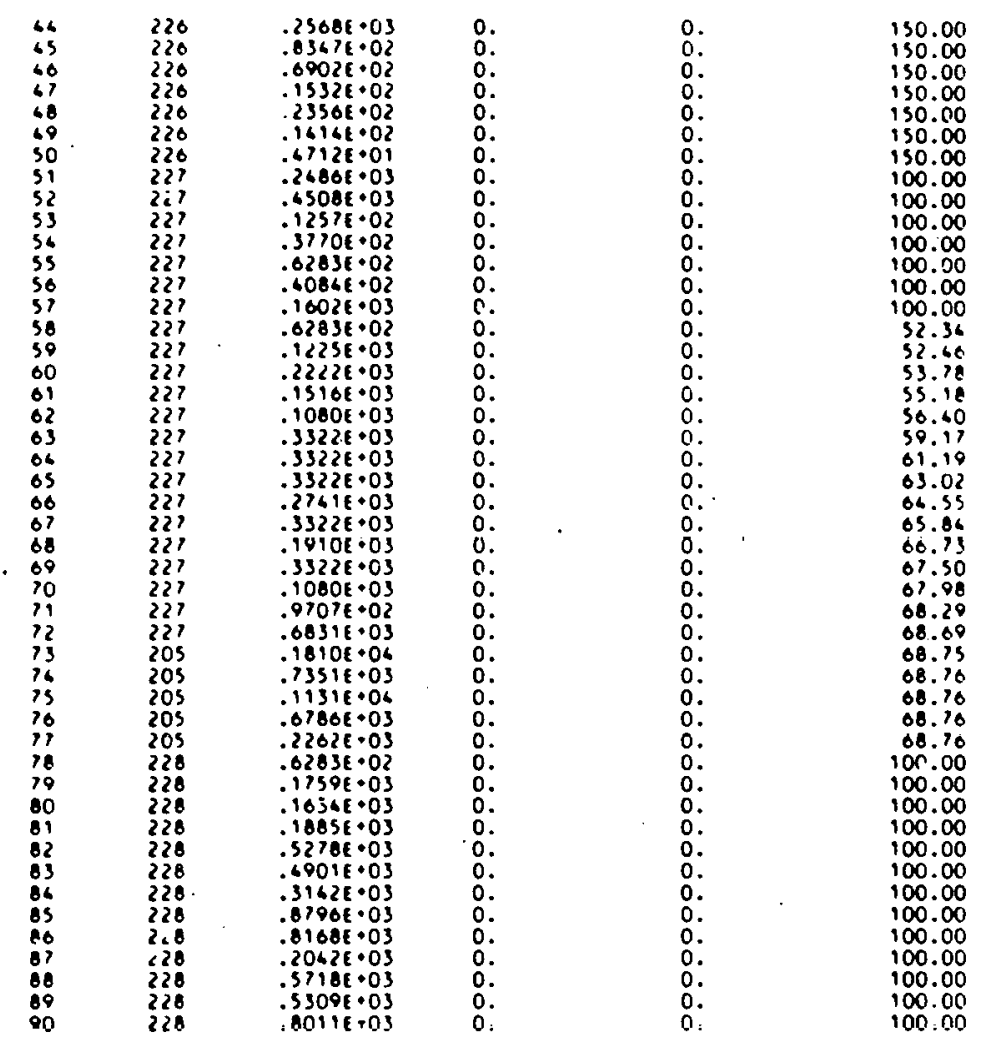

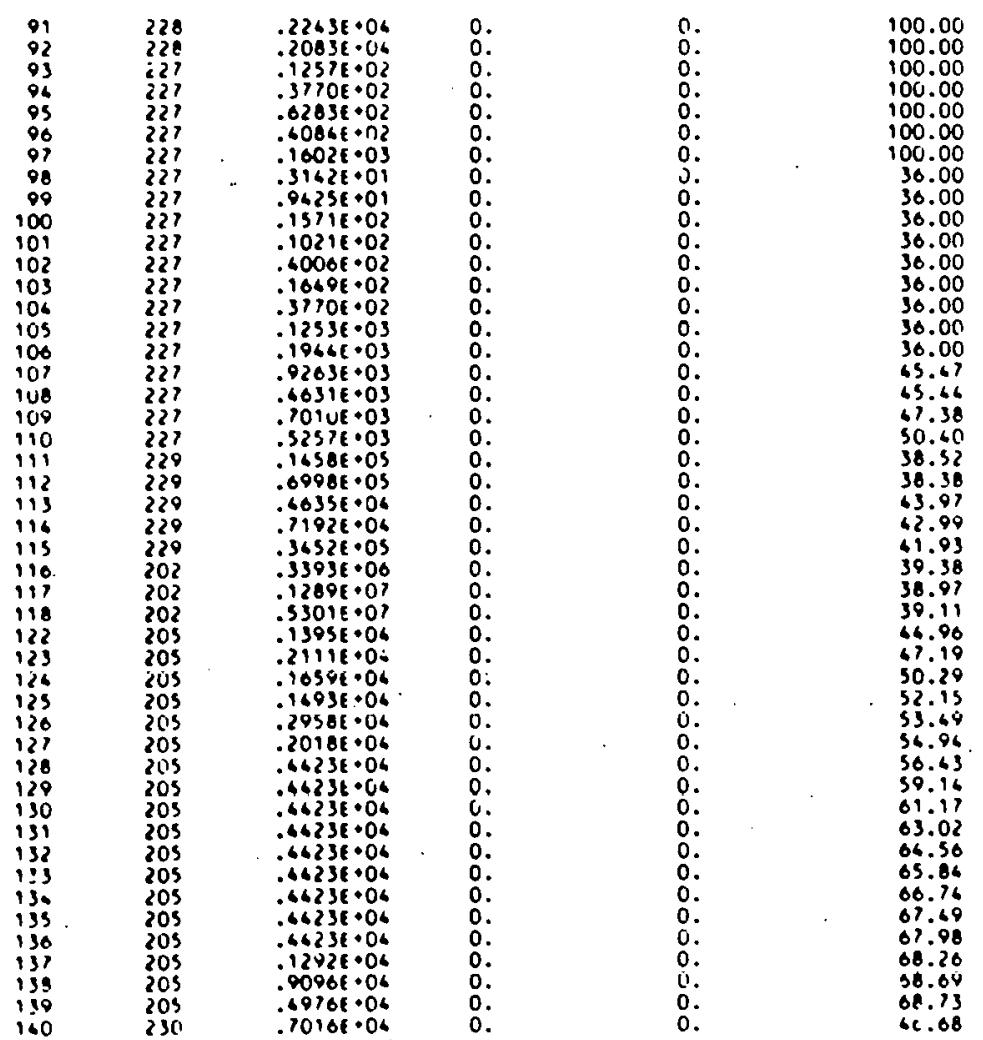


TAP-A OUTPUT (Cont'd)

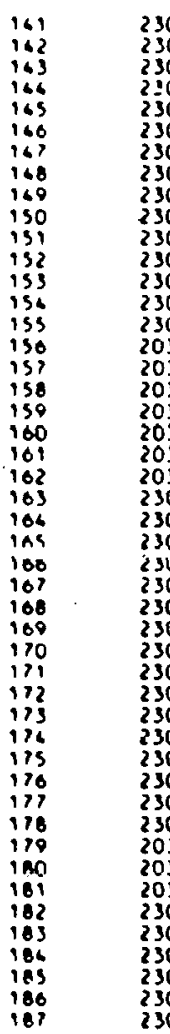

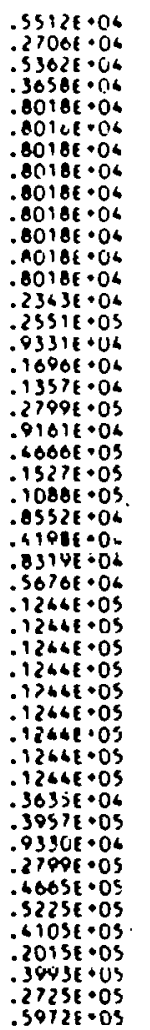

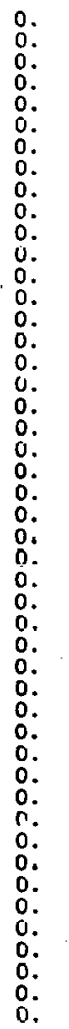

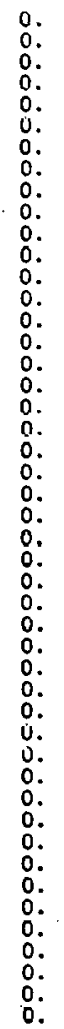

69.1

$3 . .6$

33.09

38.6

01.12

82.99

os.es

80.13

37.6?

88.21

80.70

B..71

86.71

80.60

88.30

80.30

6.11
60.12

sii. in

32.02

36.31

30.02

61.04

62.05

o. 52

05.82

66.10

So. 11

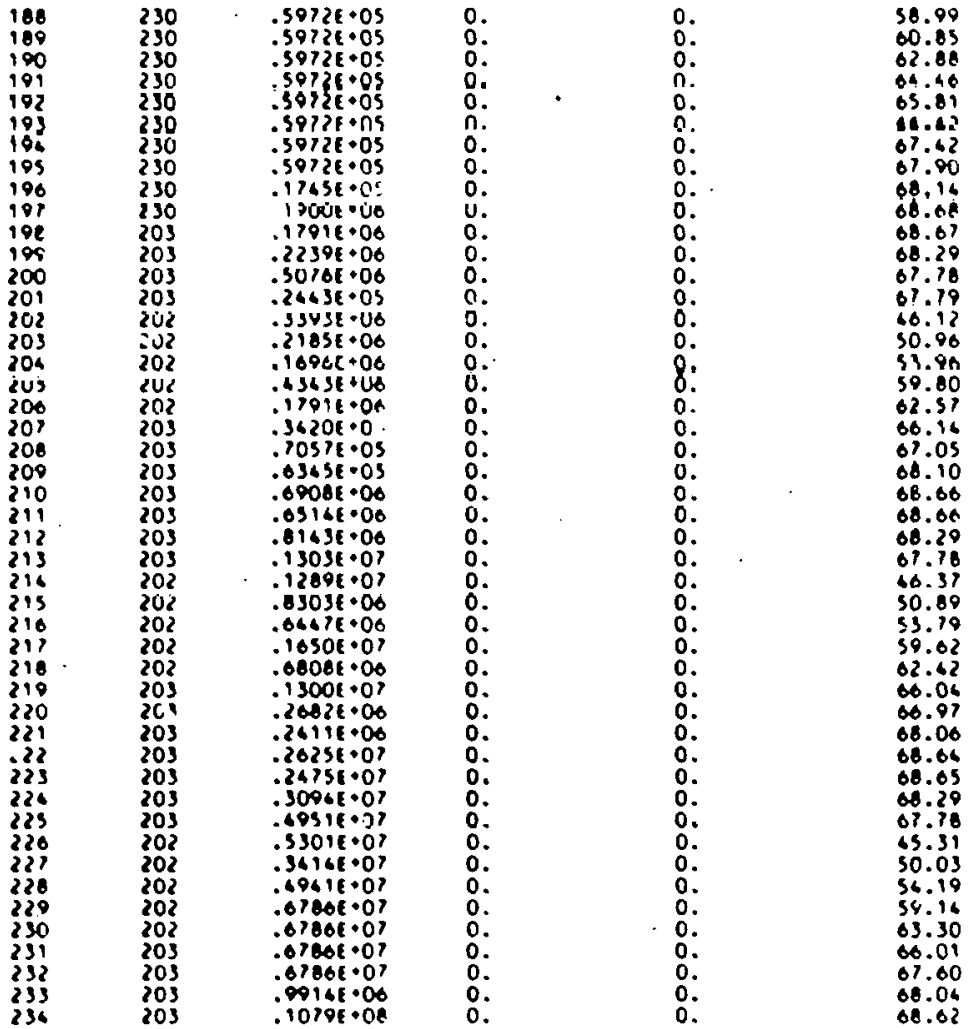

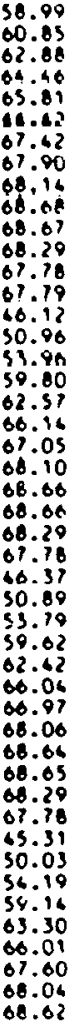

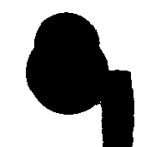




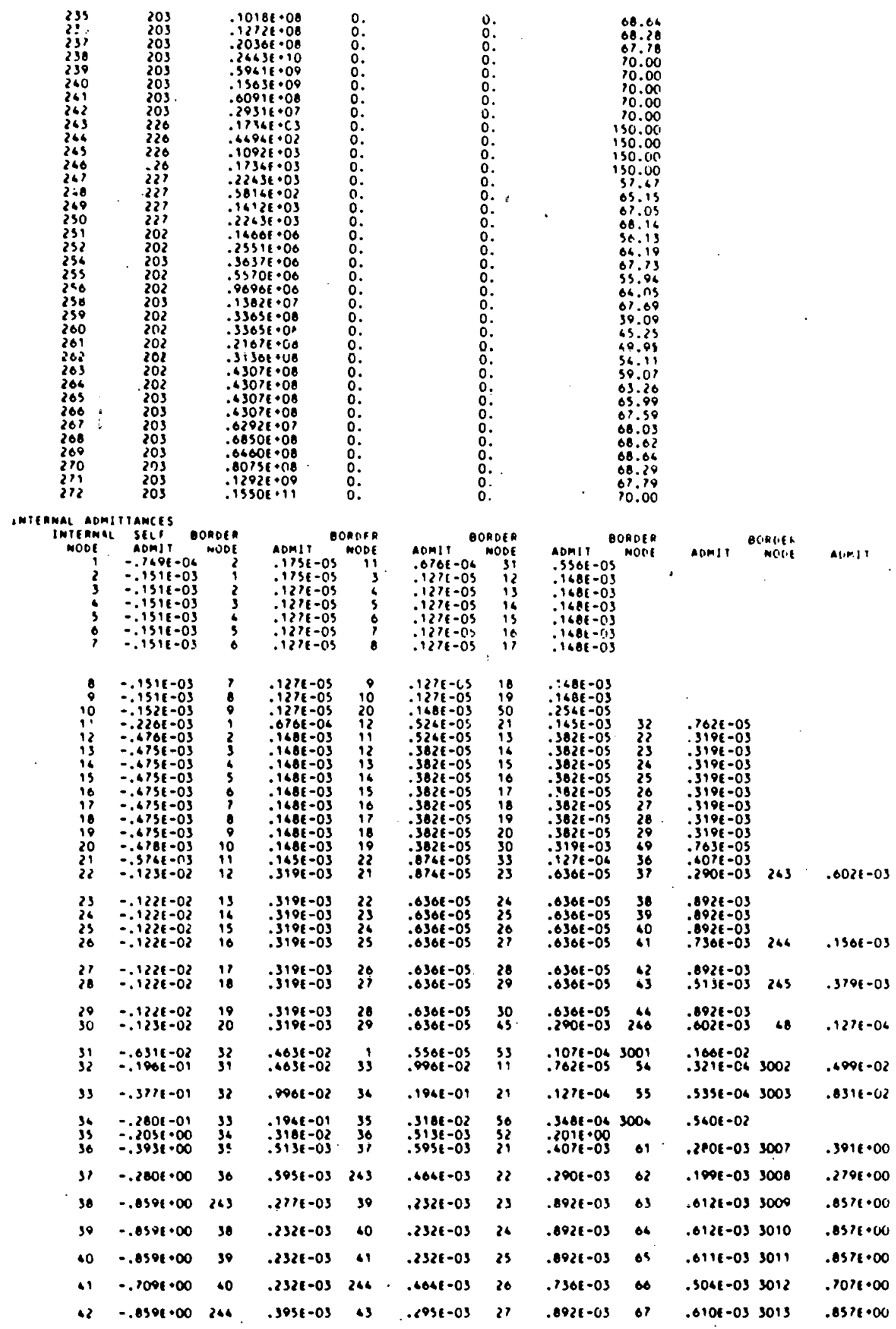


TAP-A OUTPUT (Cont'd)

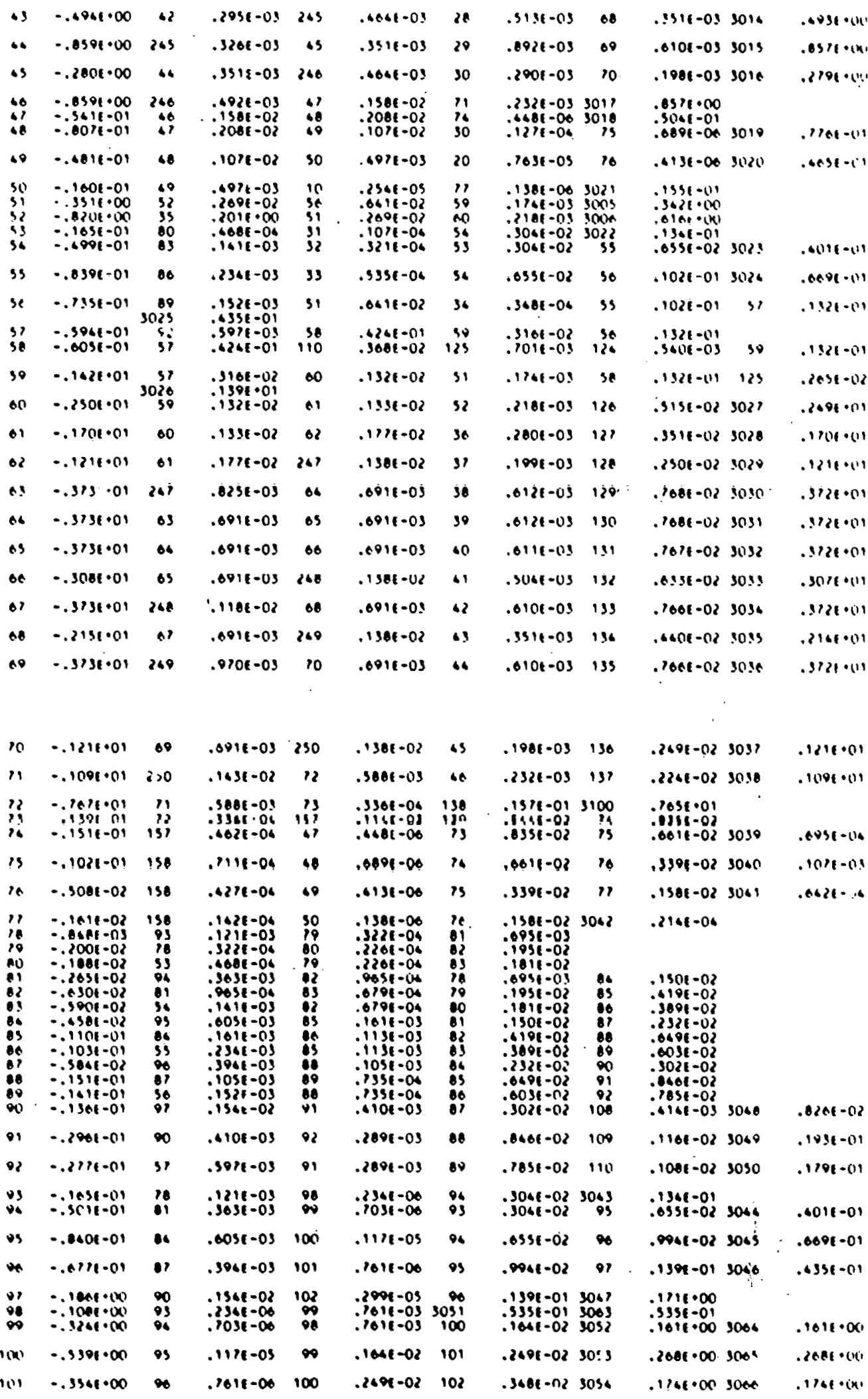




\begin{tabular}{|c|c|c|c|c|c|c|c|c|c|c|c|}
\hline 102 & -.1316 .01 & 97 & $.209 k-0 s$ & 101 & $.3486-02$ & 103 & $.5246-U 2$ & soss & $.0826+008$ & 3067 & $.6820^{\circ} 04$ \\
\hline $\begin{array}{l}103 \\
106\end{array}$ & $\begin{array}{l}-.2878+00 \\
-.1298 \cdot 01\end{array}$ & $\begin{array}{l}102 \\
122\end{array}$ & $\begin{array}{l}.526 t-02 \\
.270 t-05\end{array}$ & $\begin{array}{l}106 \\
103\end{array}$ & $\begin{array}{l}.9126-03 \\
.9126-03\end{array}$ & $\begin{array}{l}3068 \\
105\end{array}$ & $\begin{array}{l}.2816 \cdot 00 \\
.3226-02\end{array}$ & 3061 & $.6626 \cdot 00$ & 3000 & $.0626 \cdot 00$ \\
\hline 105 & -.6276 .01 & 113 & $.800 t-05$ & 106 & $.322 E-02$ & 106 & $.2766-02$ & 3062 & $.2136 \cdot 01$ & 3010 & $.2136 \cdot 01$ \\
\hline $\begin{array}{l}108 \\
101 \\
108\end{array}$ & $\begin{array}{l}-.3321+01 \\
-.1921-02 \\
-.8765+00\end{array}$ & $\begin{array}{l}111 \\
108 \\
101\end{array}$ & $\begin{array}{l}.204 E-02 \\
.192 E-02 \\
.102 E-02\end{array}$ & $\begin{array}{l}105 \\
109\end{array}$ & $\begin{array}{l}.2706-02 \\
.2296-02\end{array}$ & $\begin{array}{r}3071 \\
90\end{array}$ & $\begin{array}{l}.3316+09 \\
.616 E-03\end{array}$ & $\begin{array}{r}3072 \\
122\end{array}$ & $\begin{array}{l}.0618-02 \\
.102 E-01\end{array}$ & 3056 & $.8016 \cdot 00$ \\
\hline 100 & $-.1326 \cdot 01$ & 108 & $.229 \varepsilon-02$ & 110 & $.218 \varepsilon-02$ & 91 & $.116 E-02$ & 123 & .15se-01 & 305 & $1306 \cdot 01$ \\
\hline 110 & $-.100 E \bullet 01$ & 58 & $.3608-02$ & 100 & $.218 E-02$ & 92 & $.108 E-02$ & 126 & $.1566-01$ & 3058 & $.9786 \cdot 00$ \\
\hline $\begin{array}{l}111 \\
112\end{array}$ & $\begin{array}{l}-.9776-02 \\
-.2801-01\end{array}$ & $\begin{array}{l}100 \\
115\end{array}$ & $\begin{array}{l}.206 E-02 \\
.648 E-02\end{array}$ & $\begin{array}{l}116 \\
119\end{array}$ & $\begin{array}{l}.135 E-02 \\
.638 E-02\end{array}$ & $\begin{array}{l}112 \\
116\end{array}$ & $\begin{array}{l}.0386-02 \\
.3506-02\end{array}$ & 3013 & $.0086-02$ & 3074 & $.1001-02$ \\
\hline 193 & $-.129 E-01$ & ios & $.890 \mathrm{E}-05$ & 140 & $.9356-03$ & 116 & $.467 E-02$ & 122 & $.6626-02$ & 3060 & $.2031-0 i$ \\
\hline $\begin{array}{l}114 \\
115 \\
116\end{array}$ & $\begin{array}{l}=.1006-01 \\
=.1876-01 \\
=.6375-01\end{array}$ & $\begin{array}{l}111 \\
112 \\
202\end{array}$ & $\begin{array}{l}.135 E-02 \\
.648 E-02 \\
.110 E-01\end{array}$ & $\begin{array}{l}163 \\
182 \\
112\end{array}$ & $\begin{array}{l}.1656-02 \\
.007 E-02 \\
.350 E-02\end{array}$ & $\begin{array}{l}113 \\
116 \\
115\end{array}$ & $\begin{array}{l}.667 E-02 \\
.315 E-02 \\
.2116-02\end{array}$ & $\begin{array}{l}115 \\
116 \\
117\end{array}$ & $\begin{array}{l}.3156-02 \\
.2116-02 \\
.4906-02\end{array}$ & 3075 & $.2201-01$ \\
\hline $\begin{array}{l}117 \\
118 \\
122\end{array}$ & $\begin{array}{l}=.1265 \cdot 00 \\
=.526 E \cdot 00 \\
-.156 E-U 1\end{array}$ & $\begin{array}{l}296 \\
226 \\
106\end{array}$ & $\begin{array}{l}.3306-01 \\
.1726+00 \\
.21 \text { UE-US }\end{array}$ & $\begin{array}{l}110 \\
250 \\
123\end{array}$ & $\begin{array}{l}.690 E-02 \\
.380 E-02 \\
. \text { LUIE-US }\end{array}$ & $\begin{array}{l}118 \\
117 \\
100\end{array}$ & $\begin{array}{l}.668 E-02 \\
.668 E-02 \\
.1 U 2 E-U 1\end{array}$ & $\begin{array}{l}3076 \\
3077 \\
113\end{array}$ & $\begin{array}{l}.8368-01 \\
.3646 \cdot 00 \\
.4626-02\end{array}$ & 3054 & $.505 t-03$ \\
\hline $\begin{array}{l}123 \\
124\end{array}$ & $\begin{array}{l}-.221 E-01 \\
-.216 E-01\end{array}$ & $\begin{array}{l}122 \\
123\end{array}$ & $\begin{array}{l}.201 E-03 \\
.186 E-03\end{array}$ & $\begin{array}{l}124 \\
125\end{array}$ & $\begin{array}{l}.1806-03 \\
.282:-03\end{array}$ & $\begin{array}{r}100 \\
58\end{array}$ & $\begin{array}{l}.155 E-01 \\
.360 E-03\end{array}$ & $\begin{array}{l}160 \\
110\end{array}$ & $\begin{array}{l}.0201-02 \\
.1546-01\end{array}$ & 161 & $.6916-02$ \\
\hline 125 & $-.5916-02$ & so & $.1016-03$ & 126 & $.2826-03$ & 120 & $.3206-03$ & 39 & $.205 t-02$ & 162 & $.1758-02$ \\
\hline $\begin{array}{l}128 \\
127 \\
128\end{array}$ & $\begin{array}{l}-.9561-02 \\
=.668 t-02 \\
=.1346-01\end{array}$ & $\begin{array}{l}125 \\
126 \\
127\end{array}$ & $\begin{array}{l}.5266-03 \\
.416 E-03 \\
.366 E-03\end{array}$ & $\begin{array}{l}127 \\
128 \\
129\end{array}$ & $\begin{array}{l}.6768-03 \\
.3668-03 \\
.2668-03\end{array}$ & $\begin{array}{l}60 \\
61 \\
62\end{array}$ & $\begin{array}{l}.5156-02 \\
.3516-02 \\
.2506-02\end{array}$ & $\begin{array}{l}143 \\
166 \\
247\end{array}$ & $\begin{array}{l}.3616-02 \\
.2335-02 \\
.5191-02\end{array}$ & 165 & $.5106-02$ \\
\hline $\begin{array}{l}129 \\
130 \\
131 \\
132\end{array}$ & $\begin{array}{l}-1336-01 \\
-.1336-01 \\
-.1336-01 \\
-1335-01\end{array}$ & $\begin{array}{l}128 \\
129 \\
130 \\
131\end{array}$ & $\begin{array}{l}.2668-03 \\
.266 t-03 \\
.2068-03 \\
.2658-03\end{array}$ & $\begin{array}{l}130 \\
131 \\
132 \\
133\end{array}$ & $\begin{array}{l}.2006-03 \\
.2660-03 \\
.205 E-03 \\
.205[-03\end{array}$ & $\begin{array}{l}63 \\
64 \\
65 \\
64\end{array}$ & $\begin{array}{l}.7606-02 \\
.7686-02 \\
.7676-02 \\
.6336-02\end{array}$ & $\begin{array}{l}168 \\
147 \\
168 \\
248\end{array}$ & $\begin{array}{l}.5091-02 \\
.5096-02 \\
.5091-02 \\
.1361-02\end{array}$ & 169 & $.509 E-112$ \\
\hline 133 & $\begin{array}{l}-.1335-01 \\
=1336-01\end{array}$ & $\begin{array}{l}132 \\
133\end{array}$ & $\begin{array}{l}.2656-03 \\
.2656-03\end{array}$ & $\begin{array}{l}136 \\
135\end{array}$ & $\begin{array}{l}.205 E-03 \\
.205 E-03\end{array}$ & $\begin{array}{l}67 \\
66\end{array}$ & $\begin{array}{l}.7668-02 \\
.640 E-02\end{array}$ & $\begin{array}{l}150 \\
260\end{array}$ & $\begin{array}{l}.3006-02 \\
.3268-02\end{array}$ & 151 & $.5086-02$ \\
\hline $\begin{array}{l}135 \\
136\end{array}$ & $\begin{array}{l}-1336-09 \\
-.1346-01\end{array}$ & $\begin{array}{l}136 \\
135\end{array}$ & $\begin{array}{l}.2656-03 \\
.265 E-03\end{array}$ & $\begin{array}{l}130 \\
131\end{array}$ & $\begin{array}{l}.2656-03 \\
.6108-03\end{array}$ & $\begin{array}{l}69 \\
70\end{array}$ & $\begin{array}{l}.7668-02 \\
.2696-02\end{array}$ & $\begin{array}{l}152 \\
250\end{array}$ & $\begin{array}{l}.508 E-02 \\
.517 \in-02\end{array}$ & 153 & $.508 t-02$ \\
\hline
\end{tabular}

\begin{tabular}{|c|c|c|c|c|c|c|c|c|c|c|c|}
\hline 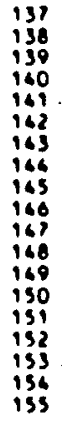 & 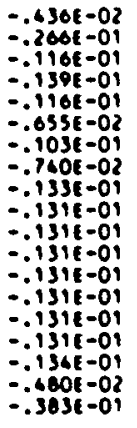 & $\begin{array}{l}136 \\
137 \\
138 \\
113 \\
160 \\
161 \\
162 \\
163 \\
164 \\
165 \\
160 \\
167 \\
168 \\
169 \\
150 \\
151 \\
152 \\
153 \\
154\end{array}$ & 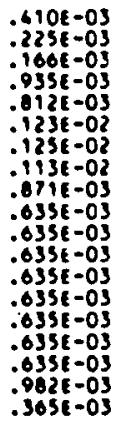 & $\begin{array}{l}138 \\
139 \\
156 \\
169 \\
162 \\
163 \\
166 \\
165 \\
166 \\
167 \\
168 \\
169 \\
150 \\
159 \\
152 \\
153 \\
156 \\
155 \\
156\end{array}$ & $\begin{array}{l}.225 E-03 \\
.160 E-03 \\
.313 E-03 \\
.812 E-03 \\
.123 E-02 \\
.125 E-02 \\
.113 E-02 \\
.871 E-03 \\
.035 E-03 \\
.035 E-03 \\
.635 E-03 \\
.635 E-03 \\
.635 E-03 \\
.035 E-03 \\
.035 E-03 \\
.035 E-03 \\
.082 E-03 \\
.363 E-03 \\
.323 E-03\end{array}$ & $\begin{array}{l}71 \\
12 \\
73 \\
123 \\
126 \\
125 \\
126 \\
127 \\
128 \\
128 \\
130 \\
131 \\
132 \\
133 \\
136 \\
135 \\
136 \\
137 \\
138\end{array}$ & 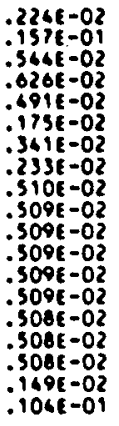 & $\begin{array}{l}156 \\
195 \\
195 \\
163 \\
166 \\
165 \\
166 \\
167 \\
168 \\
169 \\
170 \\
171 \\
172 \\
173 \\
176 \\
175 \\
176 \\
177 \\
130\end{array}$ & $\begin{array}{l}.1696-02 \\
.1066-01 \\
.5726-02 \\
.5806-02 \\
.6631-02 \\
.2311-02 \\
.4506-02 \\
.3016-02 \\
.6736-02 \\
.6731-02 \\
.6731-02 \\
.6731-02 \\
.6731-02 \\
.6731-02 \\
.6731-02 \\
.6731-02 \\
.0731-02 \\
.1971-02 \\
.5721-02\end{array}$ & 178 & $.2166-01$ \\
\hline 136 & $-.7206-02$ & 139 & $.3136-03$ & 195 & $.3236-03$ & 150 & $.056 t-03$ & 151 & $.252 !-02$ & 110 & $.347 E-02$ \\
\hline 151 & $-.467 t=02$ & 73 & $.1166-03$ & 16 & $.4626-04$ & 100 & $.119\{-0\}$ & 156 & $.2521-02$ & 158 & $.167 t-02$ \\
\hline 150 & $-.189 t-02$ & 15 & $.1116-04$ & 16 & $.4276-04$ & 17 & $.1626-06$ & 160 & $.056 E-04$ & 157 & $.1678-02$ \\
\hline $\begin{array}{l}150 \\
160 \\
101 \\
162 \\
163 \\
106 \\
103 \\
106 \\
101 \\
100 \\
109 \\
1110 \\
111 \\
113 \\
113 \\
115 \\
118 \\
117 \\
118\end{array}$ & 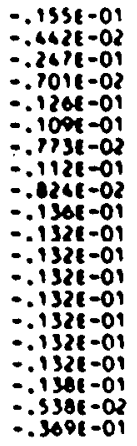 & $\begin{array}{l}150 \\
157 \\
150 \\
100 \\
116 \\
103 \\
106 \\
165 \\
106 \\
167 \\
160 \\
180 \\
170 \\
111 \\
172 \\
173 \\
178 \\
175 \\
176 \\
171\end{array}$ & 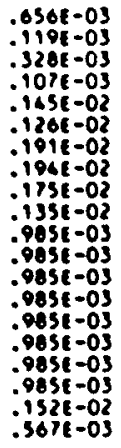 & $\begin{array}{l}161 \\
158 \\
200 \\
201 \\
164 \\
165 \\
160 \\
161 \\
160 \\
169 \\
170 \\
171 \\
172 \\
173 \\
176 \\
175 \\
176 \\
177 \\
178 \\
179\end{array}$ & 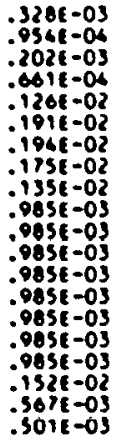 & $\begin{array}{l}160 \\
162 \\
162 \\
161 \\
160 \\
161 \\
162 \\
163 \\
164 \\
165 \\
166 \\
161 \\
168 \\
169 \\
150 \\
151 \\
152 \\
153 \\
154 \\
153\end{array}$ & 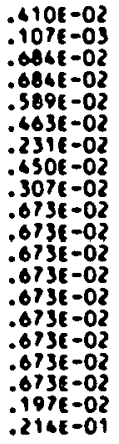 & $\begin{array}{l}180 \\
159 \\
181 \\
182 \\
183 \\
184 \\
185 \\
180 \\
187 \\
188 \\
189 \\
190 \\
191 \\
192 \\
193 \\
194 \\
195 \\
196 \\
197\end{array}$ & 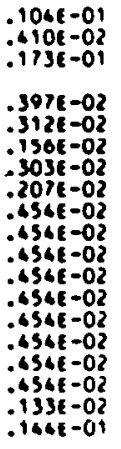 & & 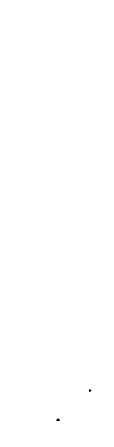 \\
\hline
\end{tabular}


TAP-A OUTPUT (Cont'd)

\begin{tabular}{|c|c|c|c|c|c|c|c|c|c|c|c|}
\hline $\begin{array}{l}170 \\
180 \\
181 \\
182 \\
183 \\
184 \\
185 \\
180 \\
181\end{array}$ & $\begin{array}{l}-.0036-02 \\
-.2161-01 \\
-.3696-01 \\
-.2006-01 \\
-.2076-01 \\
-.2128-01 \\
-.2308-01 \\
-.1856-01 \\
-.1926-01\end{array}$ & $\begin{array}{l}178 \\
178 \\
180 \\
115 \\
182 \\
183 \\
186 \\
185 \\
186\end{array}$ & $\begin{array}{l}.5016-03 \\
.0506-03 \\
.3286-03 \\
.097 E-02 \\
.6058-02 \\
.9171-02 \\
.9368-02 \\
.8408-02 \\
.6496-02\end{array}$ & $\begin{array}{l}180 \\
181 \\
200 \\
183 \\
186 \\
185 \\
186 \\
187 \\
188\end{array}$ & $\begin{array}{l}.650 E-03 \\
.3286-03 \\
.202 E-03 \\
.005 E-02 \\
.917 E-02 \\
.936 E-02 \\
.840 E-02 \\
.0696-02 \\
.673 E-02\end{array}$ & $\begin{array}{l}156 \\
159 \\
161 \\
163 \\
166 \\
165 \\
160 \\
167 \\
251\end{array}$ & $\begin{array}{l}.367 E-02 \\
.1046-01 \\
.1738-01 \\
.3976-02 \\
.3126-02 \\
.1568-02 \\
.3038-02 \\
.207 E-02 \\
.2306-02\end{array}$ & $\begin{array}{l}198 \\
198 \\
109 \\
202 \\
202 \\
203 \\
203 \\
206 \\
100\end{array}$ & $\begin{array}{l}.3608-02 \\
.1021-01 \\
.1708-01 \\
.2901-02 \\
.2348-02 \\
.1118-02 \\
.2281-02 \\
.1351-02 \\
.4561-02\end{array}$ & 206 & $.1116-02$ \\
\hline $\begin{array}{l}180 \\
180 \\
190\end{array}$ & $\begin{array}{r}-1176-01 \\
-\because 176-01 \\
--1746-01\end{array}$ & $\begin{array}{l}187 \\
188 \\
188\end{array}$ & $\begin{array}{l}.6736-02 \\
.673 E-02 \\
.6735-02\end{array}$ & $\begin{array}{l}189 \\
180 \\
191\end{array}$ & $\begin{array}{l}.6736-02 \\
.6736-02 \\
.6736-02\end{array}$ & $\begin{array}{l}180 \\
170 \\
252\end{array}$ & $\begin{array}{l}.4568-02 \\
.4568-02 \\
.59 .08-0.3\end{array}$ & $\begin{array}{l}205 \\
205 \\
131\end{array}$ & $\begin{array}{l}.3618-02 \\
.3618-02 \\
.6561-02\end{array}$ & 206 & $.2816-02$ \\
\hline $\begin{array}{l}191 \\
192 \\
193 \\
196\end{array}$ & $\begin{array}{l}-11760-01 \\
-1760-01 \\
-1760-01 \\
-1176-01\end{array}$ & $\begin{array}{l}190 \\
191 \\
102 \\
193\end{array}$ & $\begin{array}{l}.6736-02 \\
.6735-02 \\
.6736-02 \\
.6736-02\end{array}$ & $\begin{array}{l}192 \\
193 \\
194 \\
195\end{array}$ & $\begin{array}{l}.4736-02 \\
.4736-02 \\
.4736-02 \\
.4736-02\end{array}$ & $\begin{array}{l}172 \\
173 \\
176 \\
236\end{array}$ & $\begin{array}{l}.456 E-02 \\
.4586-02 \\
.4568-02 \\
.2306-02\end{array}$ & $\begin{array}{l}252 \\
207 \\
201 \\
175\end{array}$ & $\begin{array}{l}.36918-02 \\
.3691-02 \\
.36918-02 \\
.4568-02\end{array}$ & 208 & $.1116-02$ \\
\hline $\begin{array}{l}195 \\
196 \\
197 \\
198\end{array}$ & $\begin{array}{l}-.200 E-01 \\
-.1246-01 \\
=.2938-01 \\
-.2085-01\end{array}$ & $\begin{array}{l}196 \\
195 \\
196 \\
191\end{array}$ & $\begin{array}{l}.6736-02 \\
.7316-02 \\
.2726-02 \\
.15315-02\end{array}$ & $\begin{array}{l}196 \\
197 \\
198 \\
106\end{array}$ & $\begin{array}{l}.7316-02 \\
.2726-02 \\
.1536-02 \\
1160 E-02\end{array}$ & $\begin{array}{l}916 \\
177 \\
178 \\
110\end{array}$ & $\begin{array}{l}.456 E-02 \\
.133 E-02 \\
.166 E-01 \\
.360 E-02\end{array}$ & $\begin{array}{l}256 \\
209 \\
210 \\
180\end{array}$ & $\begin{array}{l}.3611-02 \\
.9056-03 \\
.1086-01 \\
.1026-01\end{array}$ & 211 & $.1026=0$ \\
\hline $\begin{array}{l}109 \\
200\end{array}$ & $\begin{array}{l}=321 E-01 \\
=.253 E-01\end{array}$ & $\begin{array}{l}198 \\
161 \\
201\end{array}$ & $\begin{array}{l}.160[-02 \\
.202 E-03 \\
.046 E-02\end{array}$ & $\begin{array}{l}200 \\
181\end{array}$ & $\begin{array}{l}.969 E-02 \\
.202 E-03\end{array}$ & $\begin{array}{l}181 \\
109\end{array}$ & $\begin{array}{l}1706-01 \\
.069 E-03\end{array}$ & $\begin{array}{l}212 \\
261\end{array}$ & $\begin{array}{l}1281-01 \\
.1866-06\end{array}$ & 213 & $.1701-09$ \\
\hline $\begin{array}{l}201 \\
202\end{array}$ & $\begin{array}{l}=.651 E-02 \\
-.367 \mathrm{E}-01\end{array}$ & $\begin{array}{l}162 \\
116\end{array}$ & $\begin{array}{l}.0616-04 \\
.1106-01\end{array}$ & $\begin{array}{l}262 \\
203\end{array}$ & $\begin{array}{l}.687 E-06 \\
.1346-01\end{array}$ & $\begin{array}{l}200 \\
182\end{array}$ & $\begin{array}{l}.0646-02 \\
.298 E-02\end{array}$ & 183 & $.2366-02$ & 216 & $.4901-02$ \\
\hline 203 & $-.392 E-01$ & 202 & $.1365-01$ & 206 & $.1926-01$ & 186 & $.117 E-02$ & 185 & $.2208-02$ & 295 & $.3198-02$ \\
\hline 204 & $-.480 E-09$ & 203 & $.192 E-01$ & 251 & $.2365-01$ & 186 & $.155 E-02$ & 187 & $.1116-02$ & 216 & $.2686-02$ \\
\hline 205 & $-.382 f-01$ & 231 & $.1286-01$ & 206 & $.122 E-01$ & 188 & $.361 E-02$ & 189 & $.3698-02$ & 297 & $.0346-02$ \\
\hline $\begin{array}{l}208 \\
201\end{array}$ & $\begin{array}{l}-.3685-01 \\
-3086-01\end{array}$ & $\begin{array}{l}205 \\
232\end{array}$ & $\begin{array}{l}.1226-01 \\
.1006-01\end{array}$ & $\begin{array}{l}252 \\
208\end{array}$ & $\begin{array}{l}.1726-01 \\
.1486-01\end{array}$ & $\begin{array}{l}190 \\
192\end{array}$ & $\begin{array}{l}.261 E-02 \\
.3416-02\end{array}$ & $\begin{array}{l}218 \\
103\end{array}$ & $\begin{array}{l}.2628-02 \\
.3616-02\end{array}$ & 218 & $.034 E-U 2$ \\
\hline $\begin{array}{l}208 \\
209 \\
210 \\
211 \\
212 \\
213 \\
214 \\
215\end{array}$ & $\begin{array}{l}-.361 E-01 \\
\because 293 E-01 \\
\because 364 E-01 \\
-.304 E-01 \\
-.3336-01 \\
-.402 E-01 \\
-.935 E-01 \\
-1301 \cdot 00\end{array}$ & $\begin{array}{l}207 \\
256 \\
209 \\
210 \\
211 \\
212 \\
117 \\
216\end{array}$ & $\begin{array}{l}.1686-01 \\
1756-01 \\
.989-02 \\
.3568-02 \\
.3096-02 \\
.3526-02 \\
.3302-01 \\
.5006-01\end{array}$ & $\begin{array}{l}256 \\
210 \\
211 \\
212 \\
213 \\
240 \\
215 \\
216\end{array}$ & $\begin{array}{l}.1726-01 \\
.9891-02 \\
.3506-02 \\
.5021-02 \\
.3525-02 \\
.6735-02 \\
.3081-01 \\
.7300-01\end{array}$ & $\begin{array}{l}196 \\
196 \\
197 \\
198 \\
190 \\
200 \\
202 \\
203\end{array}$ & $\begin{array}{l}111 E-02 \\
.095 E-03 \\
.10 \Delta E-01 \\
102 E-01 \\
120 E-01 \\
110 E-01 \\
.490 E-02 \\
.319 E-02\end{array}$ & $\begin{array}{l}220 \\
221 \\
222 \\
223 \\
226 \\
225 \\
220 \\
227\end{array}$ & $\begin{array}{l}.1036-02 \\
.927 E-03 \\
.1016-01 \\
.952 E-02 \\
.1196-01 \\
.1906-01 \\
.608 E-02 \\
.301 E-02\end{array}$ & & \\
\hline $\begin{array}{l}216 \\
217 \\
218 \\
210 \\
220 \\
221 \\
222 \\
223 \\
224 \\
225 \\
220 \\
221 \\
220\end{array}$ & 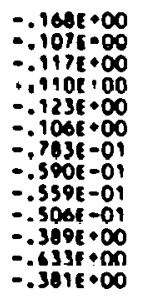 & $\begin{array}{l}215 \\
213 \\
217 \\
256 \\
218 \\
258 \\
231 \\
222 \\
223 \\
226 \\
118 \\
226 \\
227\end{array}$ & 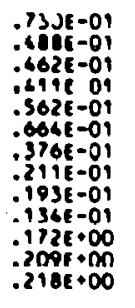 & $\begin{array}{l}255 \\
218 \\
256 \\
220 \\
258 \\
222 \\
223 \\
226 \\
225 \\
239 \\
227 \\
228 \\
229\end{array}$ & 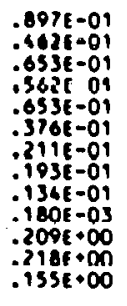 & $\begin{array}{l}206 \\
301 \\
206 \\
207 \\
208 \\
209 \\
210 \\
211 \\
212 \\
213 \\
260 \\
261 \\
255\end{array}$ & $\begin{array}{l}.268 E-02 \\
.0346-02 \\
.262 E-02 \\
.834 E-02 \\
.103 E-02 \\
.927 E-03 \\
.101 E-01 \\
.952 E-02 \\
.110 E-01 \\
.1906-01 \\
.3898-02 \\
.750 E-117 \\
.2021-02\end{array}$ & $\begin{array}{l}228 \\
229 \\
230 \\
239 \\
232 \\
233 \\
224 \\
235 \\
236 \\
237 \\
216 \\
215 \\
262\end{array}$ & 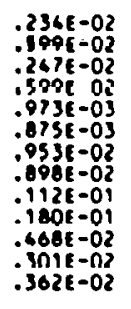 & 216 & $.2366-02$ \\
\hline $\begin{array}{l}229 \\
230\end{array}$ & $=\operatorname{yic}_{-2798}+\infty$ & $\begin{array}{l}226 \\
220\end{array}$ & $\begin{array}{l}.1998+1 M \\
.1346 \cdot 00\end{array}$ & $\begin{array}{l}24 n \\
234\end{array}$ & $\begin{array}{l}116 f+n \\
.1366+\infty\end{array}$ & $\begin{array}{l}251 \\
256\end{array}$ & $\begin{array}{l}.4941-n 2 \\
.332 c-02\end{array}$ & $\begin{array}{l}217 \\
204\end{array}$ & $\begin{array}{l}.9695=n 2 \\
.6986-02\end{array}$ & 218 & $.267 t-02$ \\
\hline $\begin{array}{l}231 \\
232\end{array}$ & $\begin{array}{l}.2798 \cdot 00 \\
.3798 \cdot 00\end{array}$ & $\begin{array}{l}230 \\
231\end{array}$ & $\begin{array}{l}.1346 \cdot 00 \\
.1366 \cdot 00\end{array}$ & $\begin{array}{l}232 \\
233\end{array}$ & $\begin{array}{l}.1368+00 \\
.2368+00\end{array}$ & 265 & $\begin{array}{l}.698 E-02 \\
.5021-02\end{array}$ & $\begin{array}{l}210 \\
206\end{array}$ & $\begin{array}{l}.5996-02 \\
.6986-02\end{array}$ & 220 & $.0736-03$ \\
\hline $\begin{array}{l}233 \\
234 \\
235 \\
230 \\
231 \\
230 \\
230 \\
240 \\
241 \\
262 \\
243\end{array}$ & 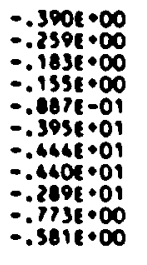 & $\begin{array}{l}232 \\
233 \\
236 \\
235 \\
230 \\
237 \\
225 \\
213 \\
200 \\
201 \\
31\end{array}$ & $\begin{array}{l}.234 E \cdot 00 \\
.153 E \cdot 00 \\
.869 E-01 \\
.795 E-01 \\
.951 E-01 \\
.740 E-03 \\
.180 E-03 \\
.673 E-04 \\
.184 E-04 \\
.867 E-06 \\
.666 E-03\end{array}$ & $\begin{array}{l}236 \\
235 \\
236 \\
237 \\
238 \\
272 \\
238 \\
230 \\
260 \\
261 \\
30\end{array}$ & 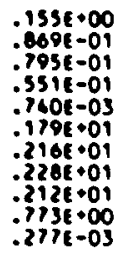 & $\begin{array}{r}267 \\
260 \\
260 \\
270 \\
271 \\
230 \\
260 \\
261 \\
262 \\
3105 \\
22\end{array}$ & $\begin{array}{l}.727 E-03 \\
.702 E-02 \\
.767 E-02 \\
.933 E-02 \\
.140 E-01 \\
.2168+01 \\
.228 E+01 \\
.212 E+01 \\
.773 E+00 \\
.895 E-06 \\
.002 E-03\end{array}$ & $\begin{array}{l}221 \\
222 \\
223 \\
226 \\
225 \\
3109 \\
3102 \\
3103 \\
3106 \\
267\end{array}$ & $\begin{array}{l}.875 E-03 \\
.953 E-02 \\
.698 E-02 \\
.1126-01 \\
.1806-01 \\
.7606-03 \\
.1816-03 \\
.6716-06 \\
.1868-06 \\
.616 E-03\end{array}$ & 3092 & $.3706 \cdot 00$ \\
\hline 244 & $1511 \cdot 00$ & 61 & $.4642-03$ & 42 & $.3955-03$ & 20 & $.1508-03$ & 248 & $.1076-03$ & 3093 & $.150 E \cdot 00$ \\
\hline 245 & $.3001 \cdot 00$ & 43 & $.664 t-03$ & 44 & $.3268-03$ & 28 & $.3106-03$ & 260 & $.259[-03$ & 3096 & $.3046 \cdot 00$ \\
\hline 246 & $-.5818+00$ & 45 & $1646-03$ & 46 & $.4926-03$ & 30 & $.6026-03$ & 250 & $.612 E-03$ & 3005 & $.5796 \cdot 00$ \\
\hline 247 & $.2521 \bullet 01$ & 42 & $.1386-02$ & 6) & $.825 e-03$ & 263 & .4146 & 128 & $.5196-02$ & 3096 & $.251 E \cdot 01$ \\
\hline 40 & $358 \cdot 00$ & $\infty$ & $.1380-02$ & 67 & $.1186-02$ & 264 & $.107 e-03$ & 132 & $.1346-02$ & 007 & $.651 E \cdot 00$ \\
\hline 49 & $1540 \cdot 01$ & 6 & $.13 e c-02$ & 69 & $.970<-03$ & 265 & $.2596-03$ & 134 & $.3266-02$ & 998 & $.1586 \cdot 01$ \\
\hline 0 & $2328 \div 01$ & 10 & $.1308-02$ & $n$ & $.1638-02$ & 266 & $.4126-03$ & 136 & $.517 c-02$ & 3000 & $.2516 \cdot 01$ \\
\hline 231 & $4001-01$ & 204 & $.2361-01$ & 205 & $.1286-01$ & 187 & $230 \varepsilon-02$ & 255 & $.216 E-02$ & & \\
\hline
\end{tabular}


TAP-A OUTPUT (Cont'd)

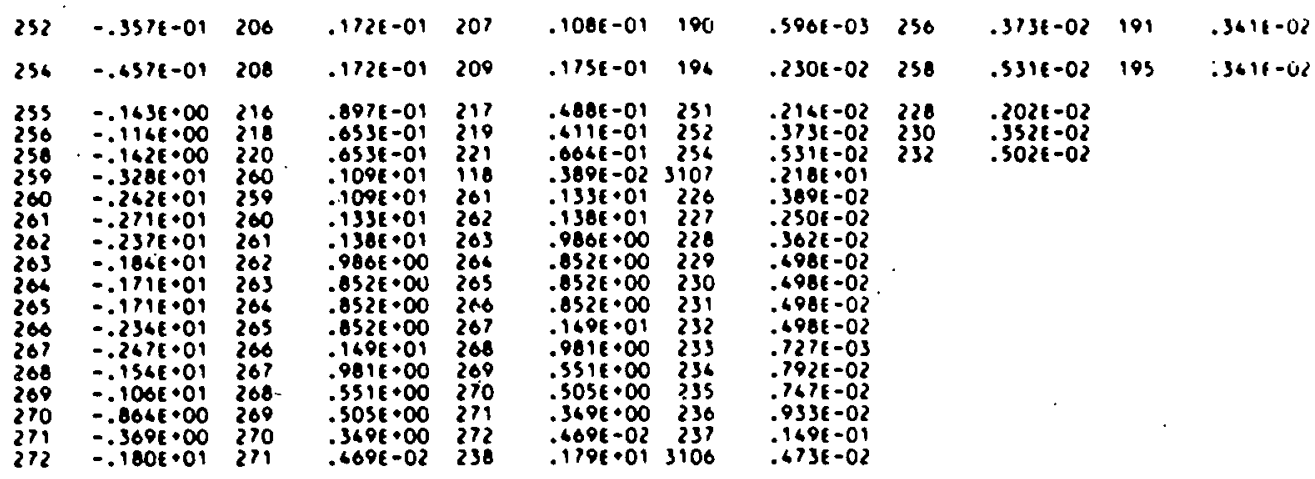

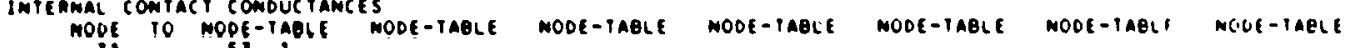

31 TO MOOE-TAOH

\$s $\because$ :

so $3:$

623.

ㅇ․ 3 . 3 .

65 3.

$\begin{array}{lll}\infty & 3 \\ 01 & 3 & 3\end{array}$

of 3 .

in 3.

71

$78:$

70 .

39

39 3.

32 i:

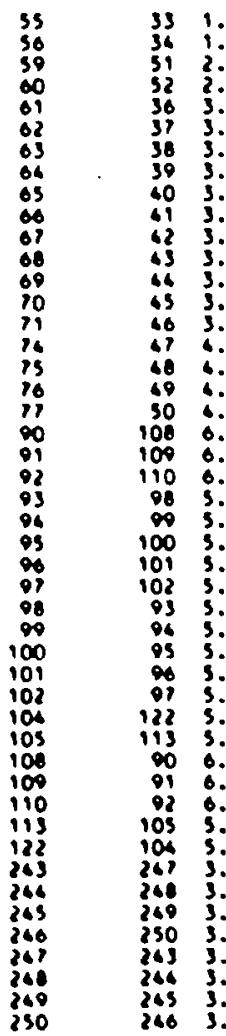




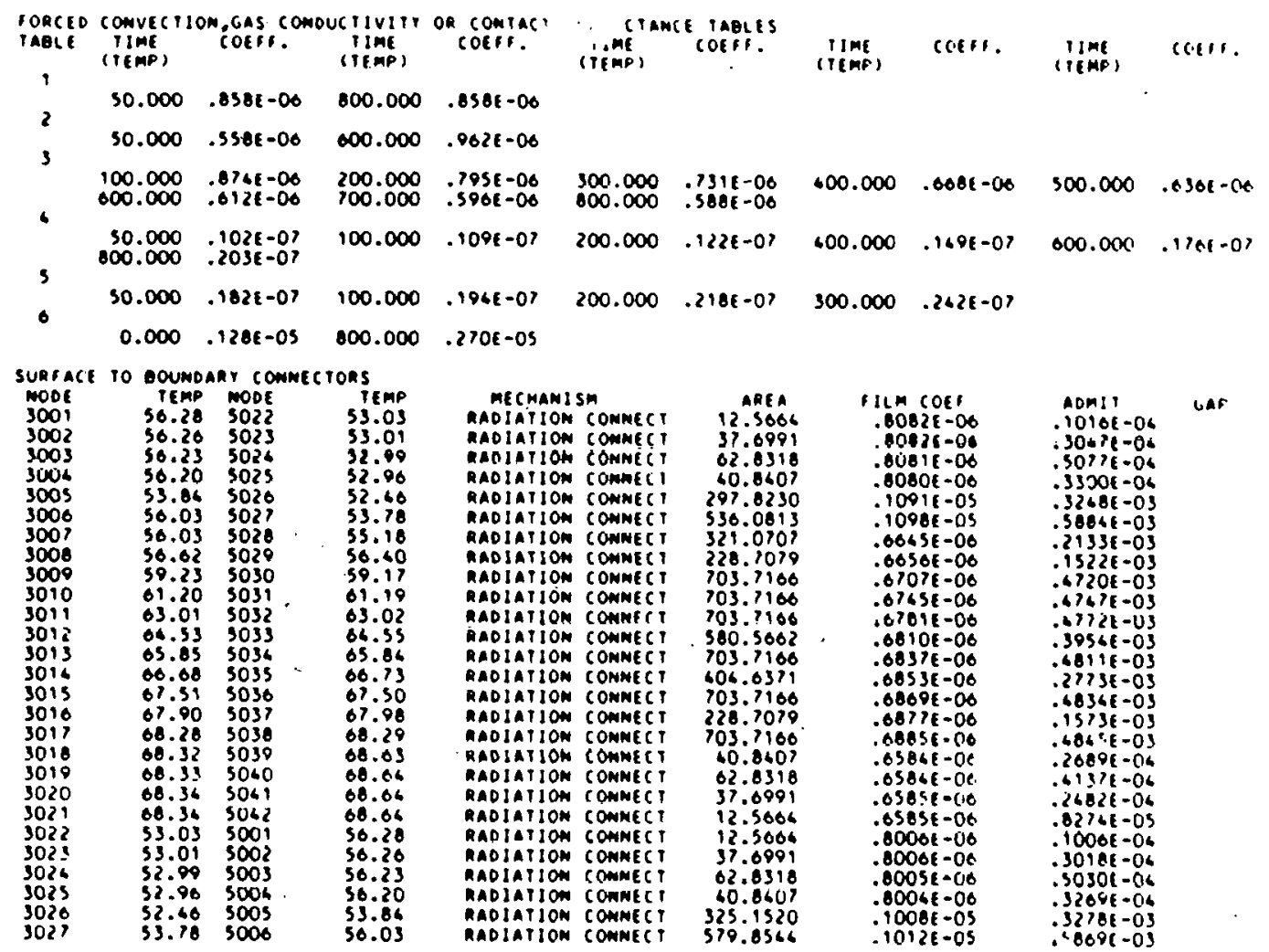

\begin{tabular}{|c|c|c|c|c|c|c|c|c|}
\hline 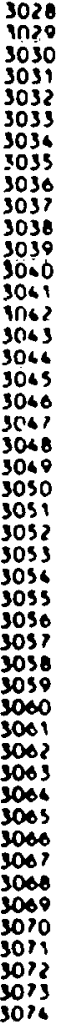 & 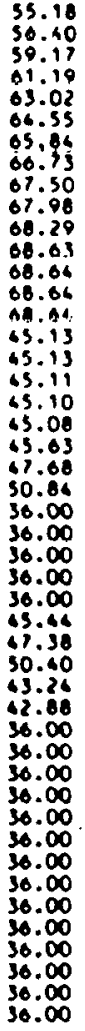 & 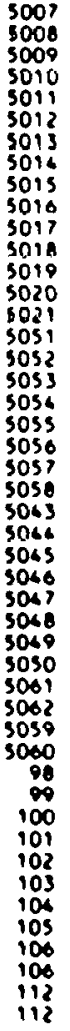 & 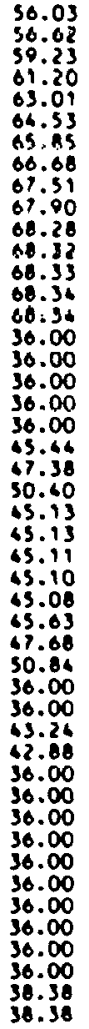 & 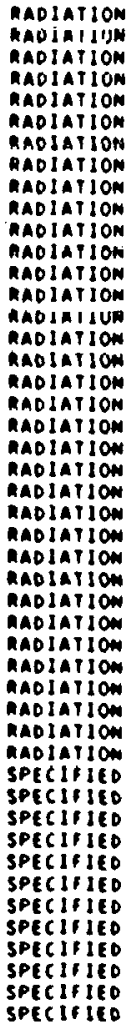 & 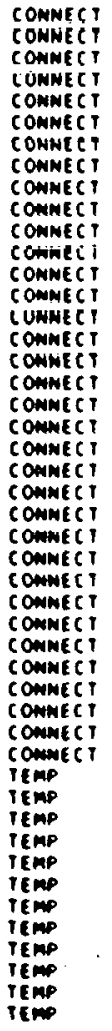 & 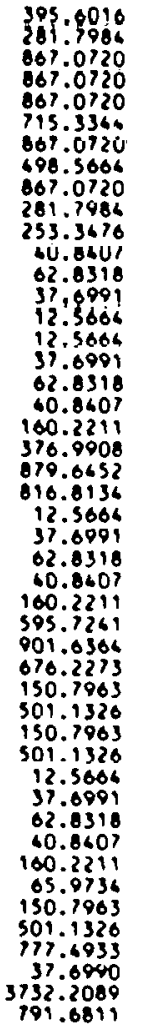 & 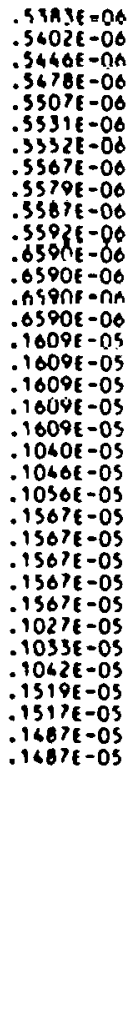 & 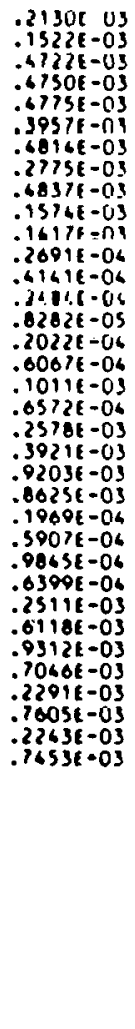 \\
\hline
\end{tabular}


TAP-A OUTPUT (Cont'd)

\begin{tabular}{|c|c|c|c|c|c|c|c|c|}
\hline $\begin{array}{l}3075 \\
3070 \\
3017 \\
3092 \\
3093 \\
3096 \\
3095 \\
3096 \\
3097 \\
3098 \\
3090 \\
3101 \\
3102 \\
3103 \\
3106 \\
3103 \\
3106 \\
3107 \\
3001 \\
3002 \\
3003 \\
3006 \\
3005 \\
3006 \\
3007 \\
3006 \\
3009 \\
3010 \\
3011 \\
3012 \\
3013 \\
3016 \\
3015 \\
3016 \\
3017 \\
3018 \\
3019 \\
3020 \\
3021 \\
3022 \\
3023 \\
3026 \\
3025 \\
3026 \\
3027 \\
3028 \\
3029 \\
\end{array}$ & $\begin{array}{l}36.00 \\
36.00 \\
36.00 \\
57.56 \\
63.16 \\
67.03 \\
68.11 \\
57.67 \\
65.15 \\
67.05 \\
68.16 \\
70.00 \\
70.00 \\
70.00 \\
70.00 \\
30.00 \\
70.00 \\
0.00 \\
56.28 \\
56.26 \\
56.23 \\
56.20 \\
53.86 \\
56.03 \\
36.03 \\
56.02 \\
59.23 \\
61.20 \\
63.01 \\
66.53 \\
65.85 \\
66.68 \\
67.51 \\
67.90 \\
68.28 \\
68.32 \\
60.33 \\
60.34 \\
68.36 \\
53.03 \\
53.01 \\
53.09 \\
52.96 \\
52.66 \\
53.78 \\
55.18 \\
56.40\end{array}$ & $\begin{array}{l}116 \\
117 \\
110 \\
5083 \\
5086 \\
5085 \\
5080 \\
5070 \\
5080 \\
5081 \\
5082 \\
230 \\
239 \\
260 \\
241 \\
242 \\
212 \\
250 \\
5001 \\
5002 \\
5003 \\
5006 \\
5005 \\
5006 \\
5007 \\
5008 \\
5000 \\
5010 \\
5011 \\
5012 \\
5013 \\
5016 \\
5015 \\
5016 \\
5017 \\
5018 \\
5019 \\
5020 \\
5021 \\
5022 \\
5023 \\
5026 \\
5025 \\
5020 \\
5027 \\
5028 \\
5029\end{array}$ & 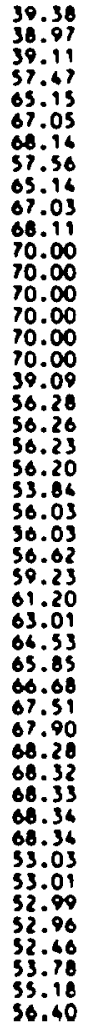 & 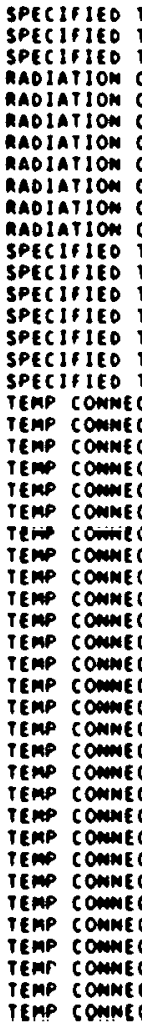 & 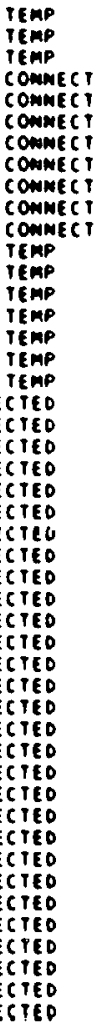 & 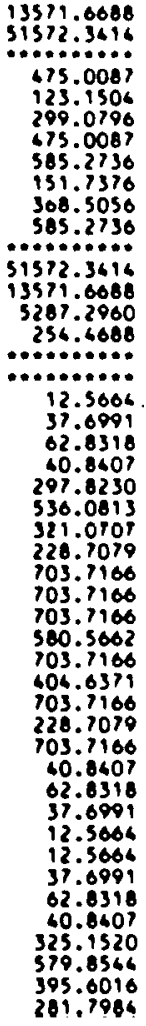 & $\begin{array}{l}.06761-06 \\
.08231-06 \\
.68601-06 \\
.68811-06 \\
.56191-06 \\
.55611-06 \\
.55721-06 \\
.55891-06\end{array}$ & $\begin{array}{l}31706-03 \\
.86026-04 \\
.20526-03 \\
.32696-03 \\
.31726-03 \\
.86086-04 \\
.20536-03 \\
.32711-03 \\
.\end{array}$ \\
\hline
\end{tabular}

\begin{tabular}{|c|c|c|c|c|c|c|}
\hline 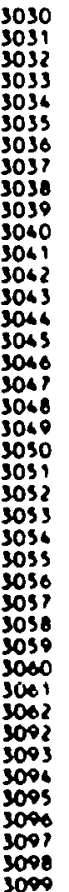 & 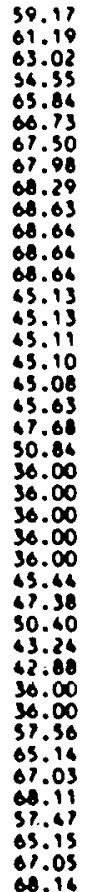 & 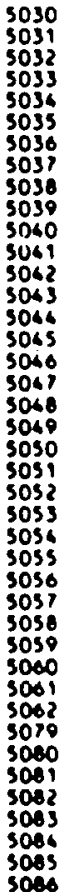 & 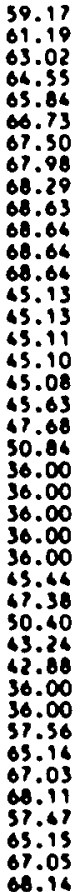 & 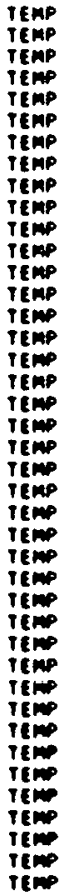 & 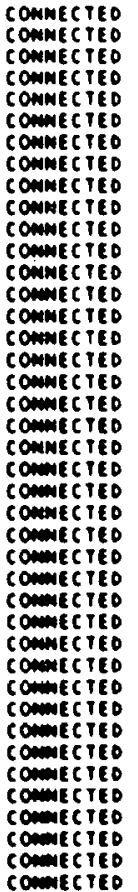 & $\begin{array}{l}867.0720 \\
867.0720 \\
667.0720 \\
715.3364 \\
867.0720 \\
498.3066 \\
667.0720 \\
281.7986 \\
253.3676 \\
40.8407 \\
62.8318 \\
37.6901 \\
12.5664 \\
12.5664 \\
37.6991 \\
62.8318 \\
60.8607 \\
160.2211 \\
376.9908 \\
679.6452 \\
816.8136 \\
12.5064 \\
37.6901 \\
62.8318 \\
60.8407 \\
160.2211 \\
595.7261 \\
901.6366 \\
676.2273 \\
150.7963 \\
501.1326 \\
150.7963 \\
501.1326 \\
675.0067 \\
123.1504 \\
299.0796 \\
675.0067 \\
585.2136 \\
151.7376 \\
360.5056 \\
585.2736\end{array}$ \\
\hline
\end{tabular}

elimioni rimes

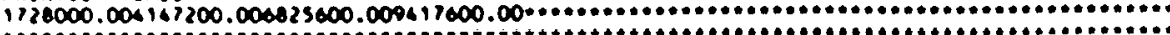

calculte spacad ofturen inteamal mools 221 
TAP-A OUTPUT (Cont'd)

Drywe11 5 Predictions - February 1,1979

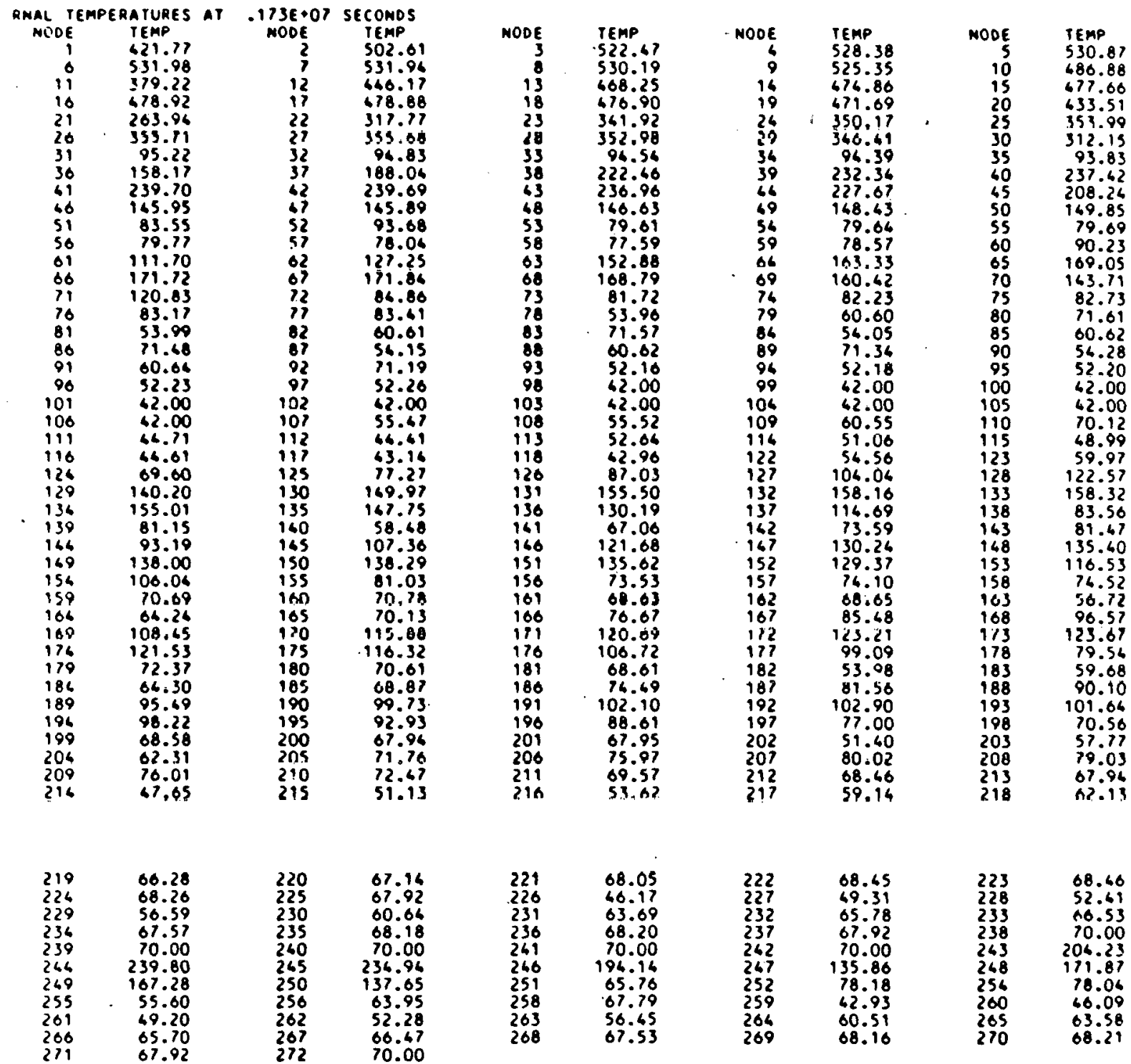


Drywe11 5 Predictions - March 1, 1979

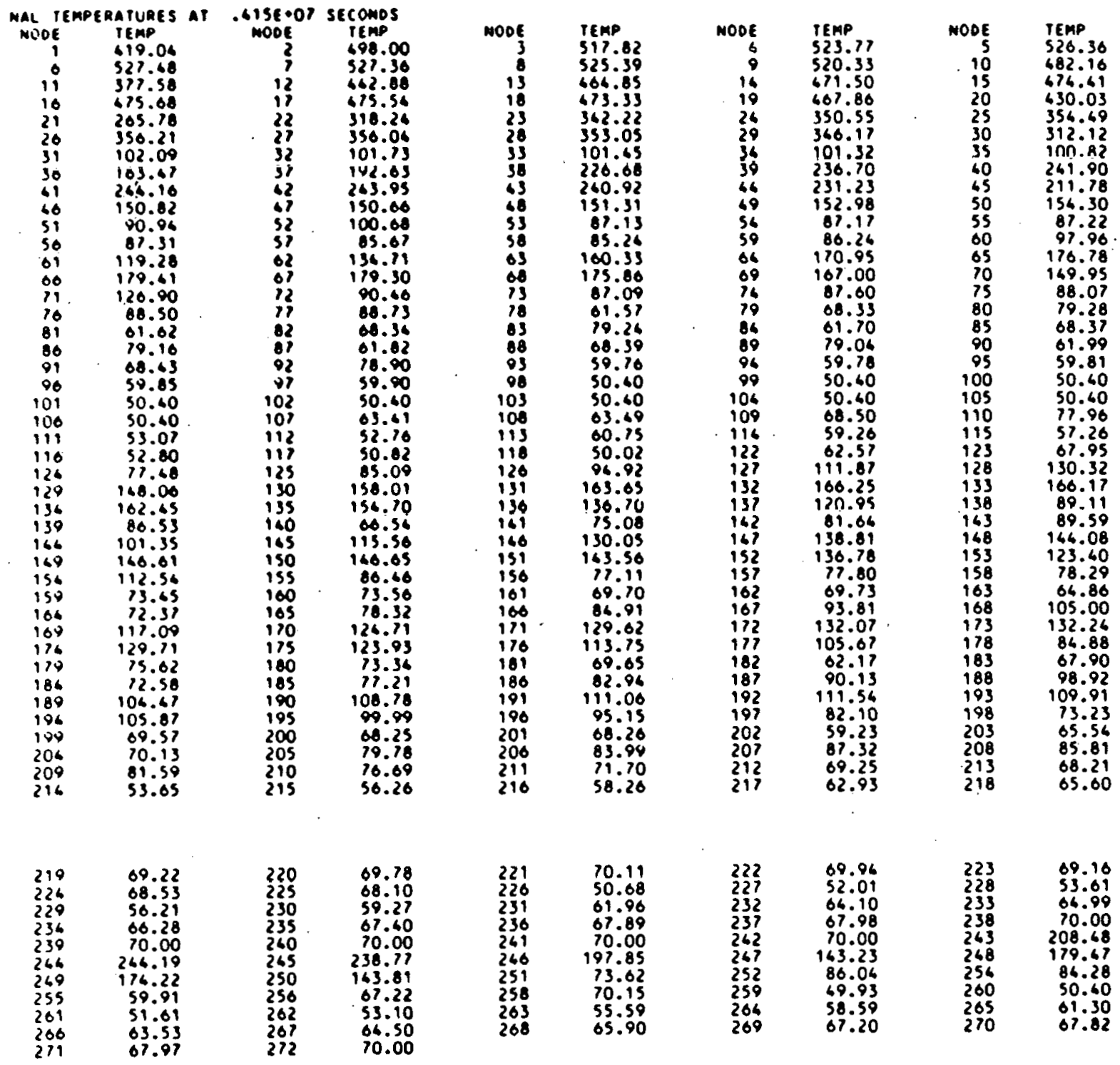


TAP-A OUTPUT (Cont'd)

Drywell 5 Predictions - April 1, 1979

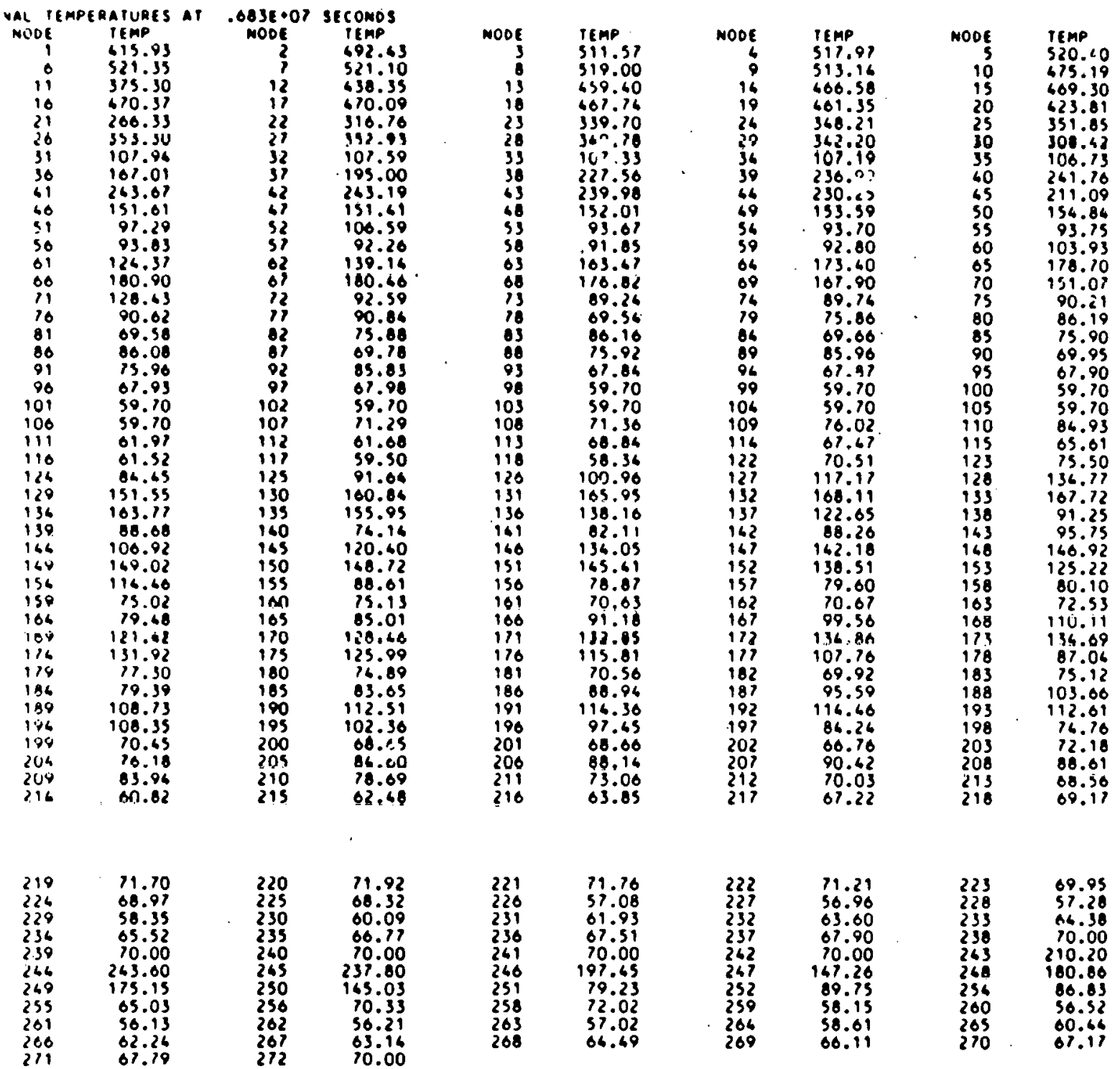


Drywe11 5 Predictions - May 1, 1979

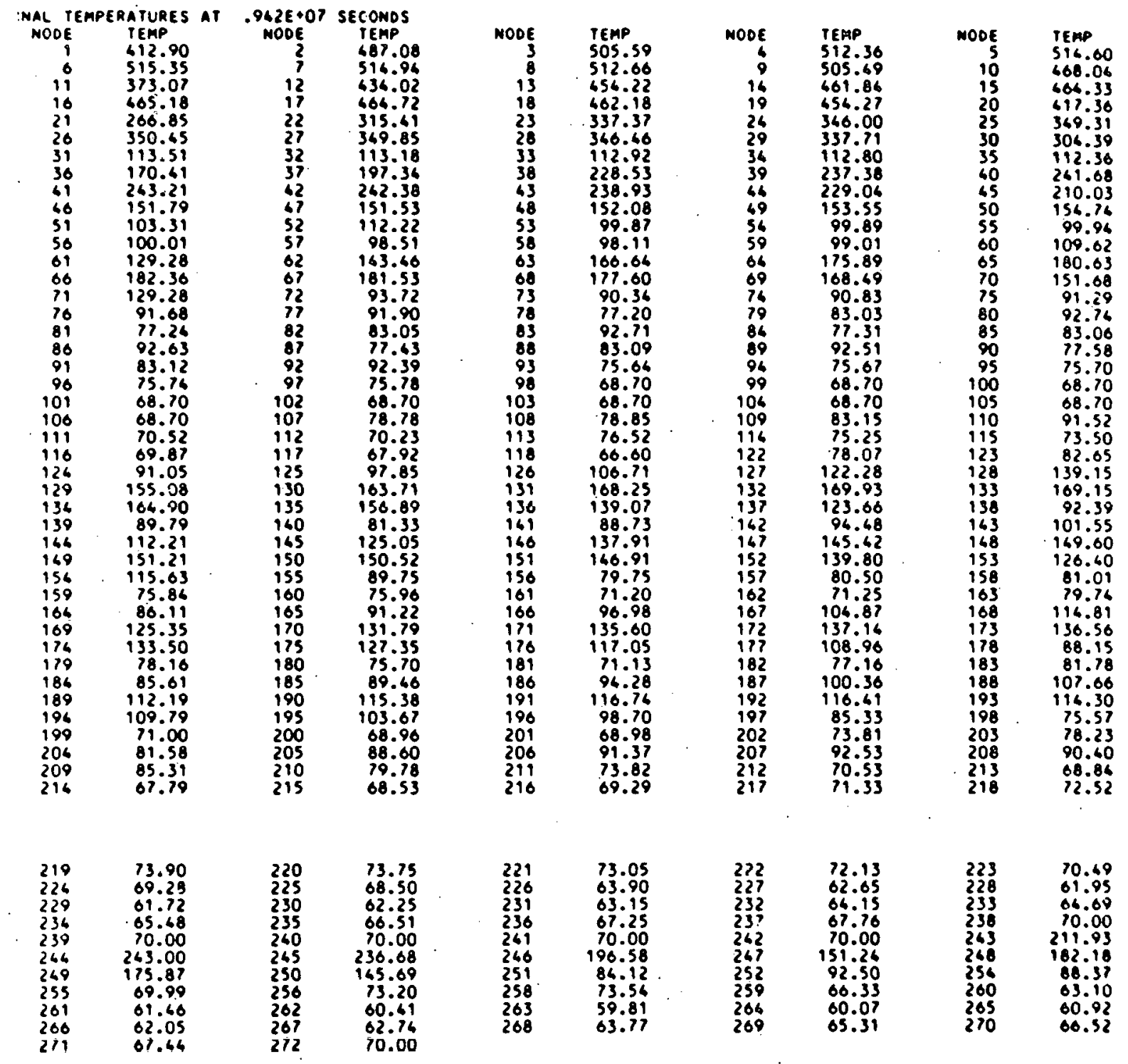


TAP-A OUTPUT (Cont'd)

Drywe11 5 Predictions - June 1, 1979

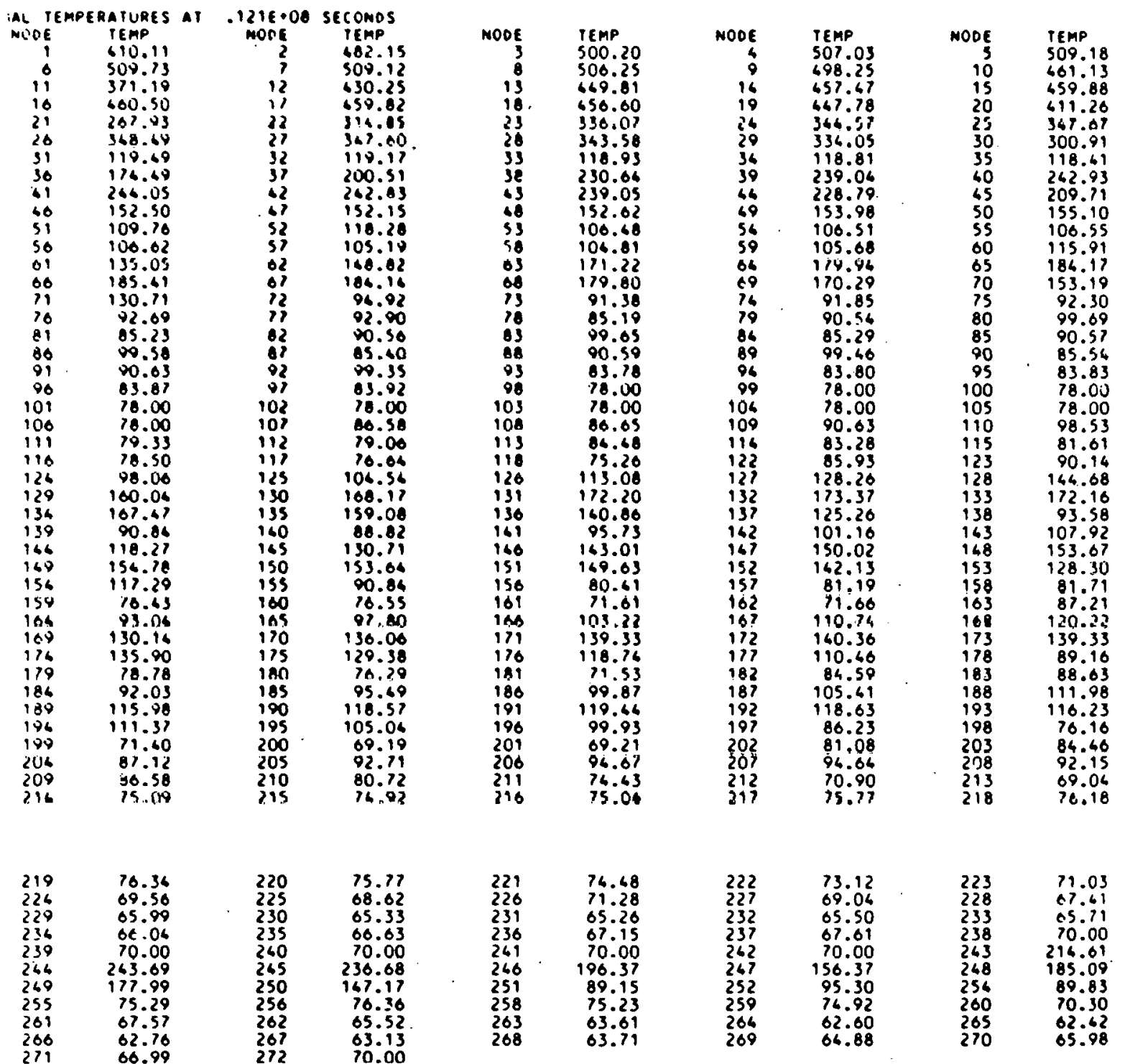


Dryivel1 5 Predictions - July 1, 1979.

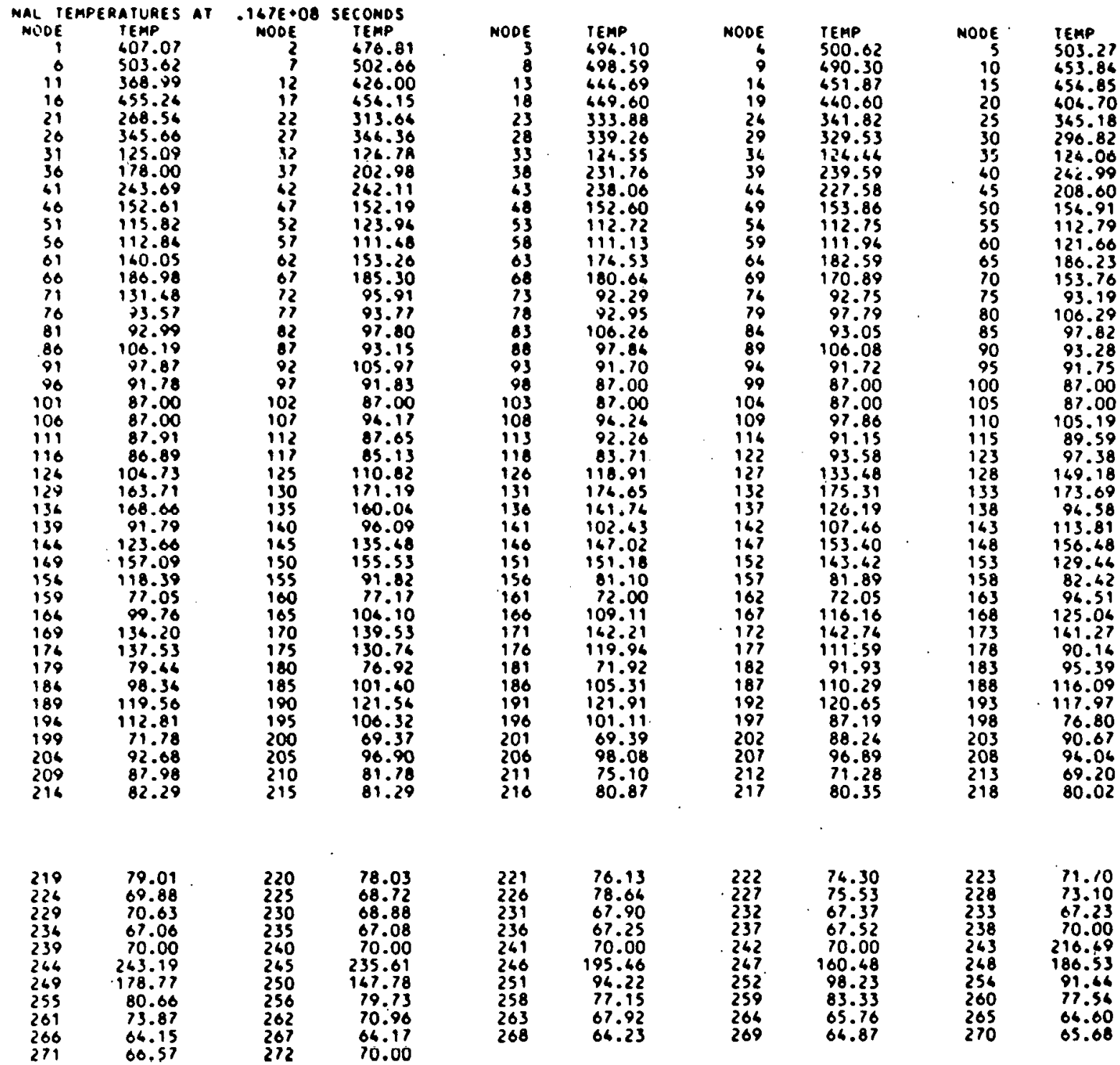


TAP-A OUTPUT (Cont'd)

Drywel1 5 Predictions - August 1, 1979

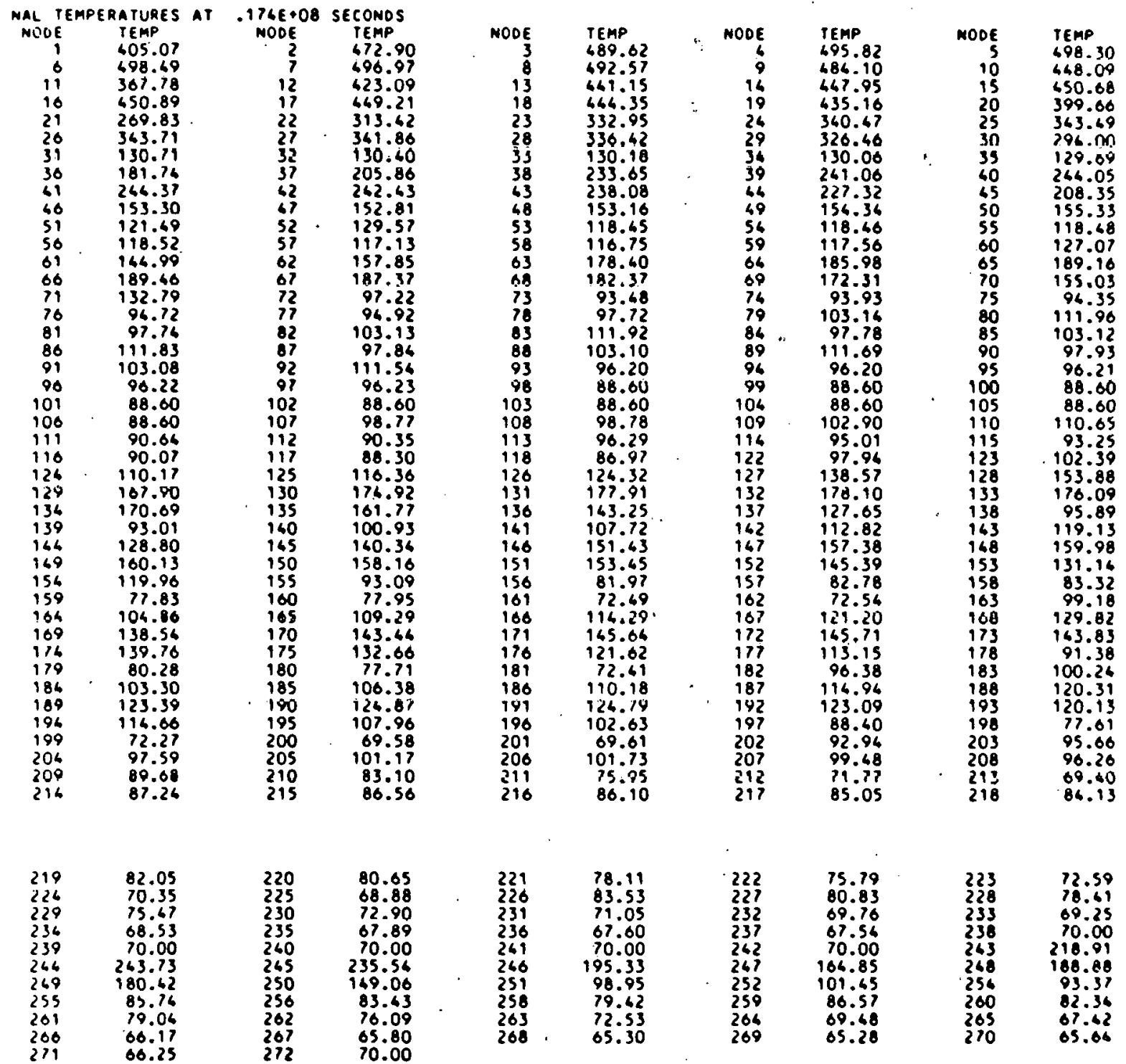

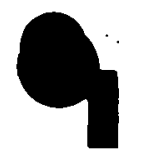


TAP-A OUTPUT (Cont'd)

Drywe11 5 Predictions - September 1, 1979

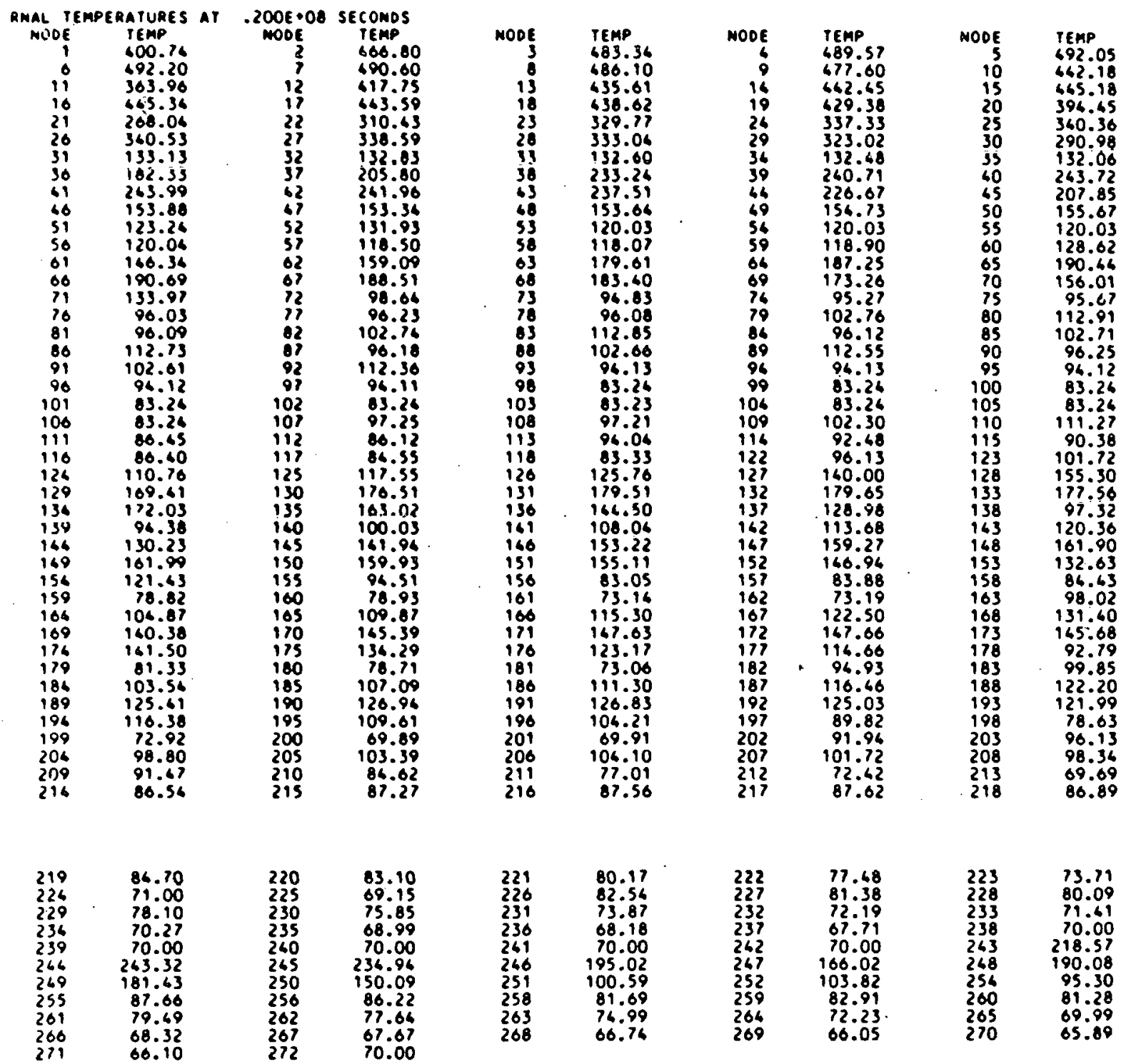


TAP-A OUTPUT (Cont'd)

Drywel1 5 Predictions - October 1, 1979

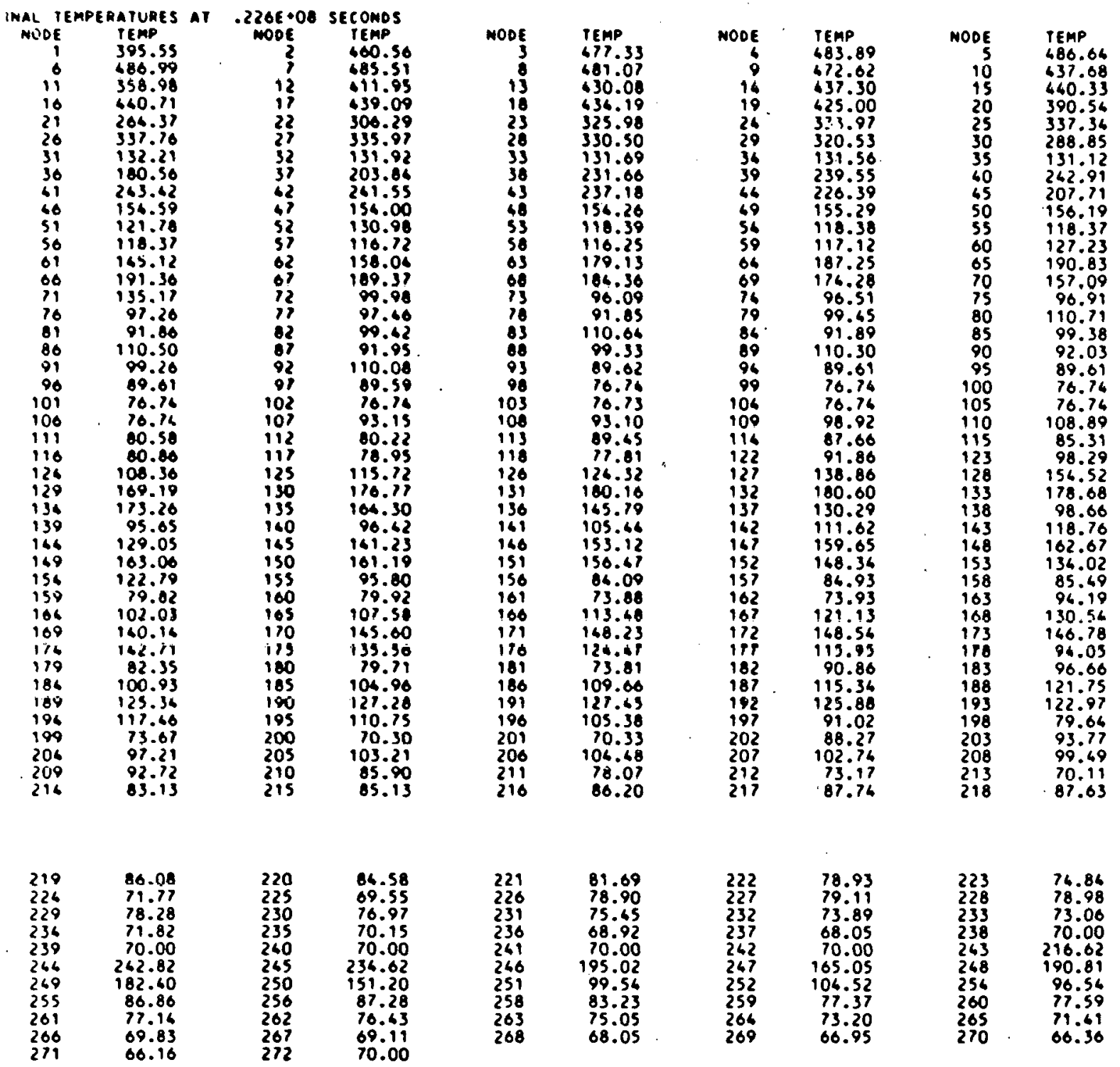


TAP-A OUTPUT (Cont'd)

Drywell 5 Predictions - November 1, 1979

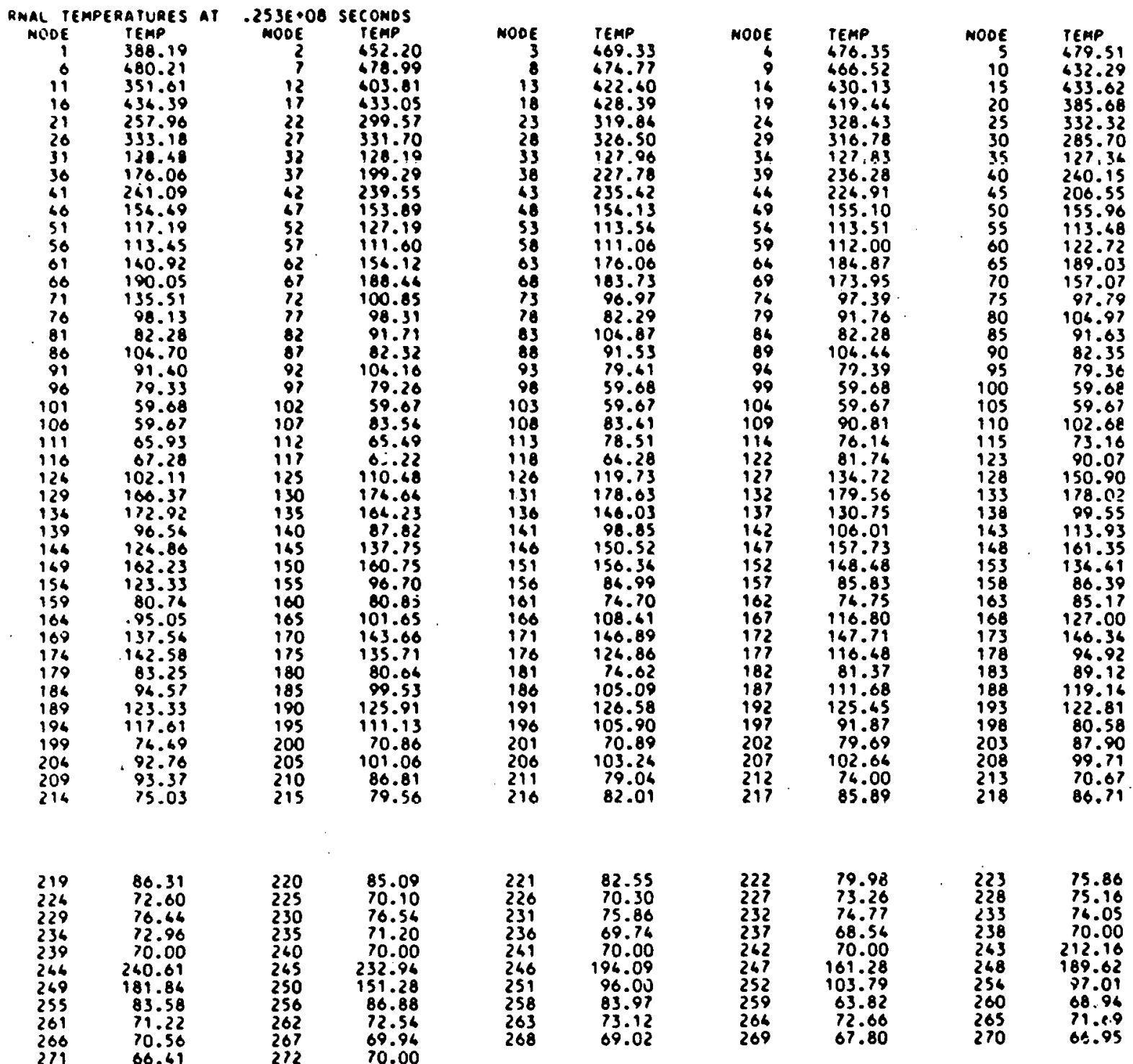


TAP-A OUTPUT (Cont'd)

Drywe11 5 Predictions - December 1, 1979

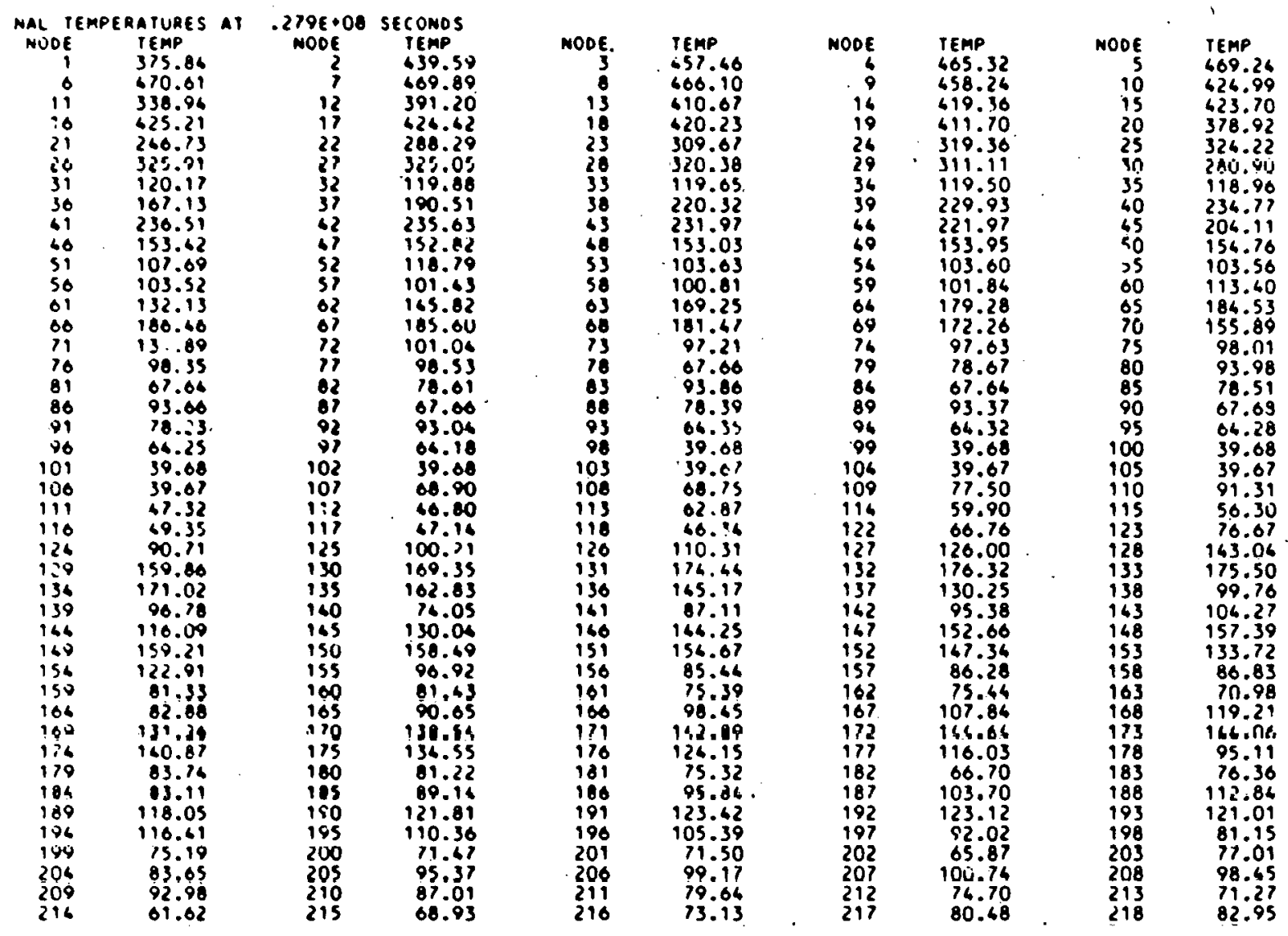

\begin{tabular}{|c|c|c|c|c|c|c|c|c|}
\hline $\begin{array}{l}219 \\
224 \\
229 \\
234 \\
239 \\
244 \\
249 \\
255 \\
261 \\
266\end{array}$ & $\begin{array}{r}84.73 \\
73.32 \\
70.97 \\
73.61 \\
70.00 \\
236.29 \\
179.71 \\
75.98 \\
60.16 \\
70.09\end{array}$ & $\begin{array}{l}220 \\
225 \\
230 \\
235 \\
240 \\
245 \\
250 \\
256 \\
262 \\
267\end{array}$ & $\begin{array}{r}86.13 \\
70.70 \\
73.52 \\
71.92 \\
70.00 \\
229.64 \\
150.26 \\
86.09 \\
64.02 \\
69.80\end{array}$ & $\begin{array}{l}221 \\
226 \\
231 \\
236 \\
261 \\
246 \\
251 \\
258 \\
263 \\
268\end{array}$ & $\begin{array}{r}82.39 \\
56.35 \\
76.67 \\
70.46 \\
70.00 \\
191.96 \\
88.17 \\
83.50 \\
67.57 \\
.69 .33\end{array}$ & $\begin{array}{l}222 \\
227 \\
232 \\
237 \\
262 \\
267 \\
252 \\
259 \\
266 \\
269\end{array}$ & $\begin{array}{r}80.33 \\
62.25 \\
76.60 \\
69.11 \\
70.00 \\
153.26 \\
100.68 \\
45.87 \\
69.56 \\
68.35\end{array}$ & $\begin{array}{r}76.53 \\
66.71 \\
76.03 \\
70.00 \\
203.66 \\
186.08 \\
96.26 \\
56.96 \\
70.20 \\
67.69\end{array}$ \\
\hline
\end{tabular}


TAP-A OUTPUT (Cont'd)

Drywe11 5 Predictions - January 1, 1980

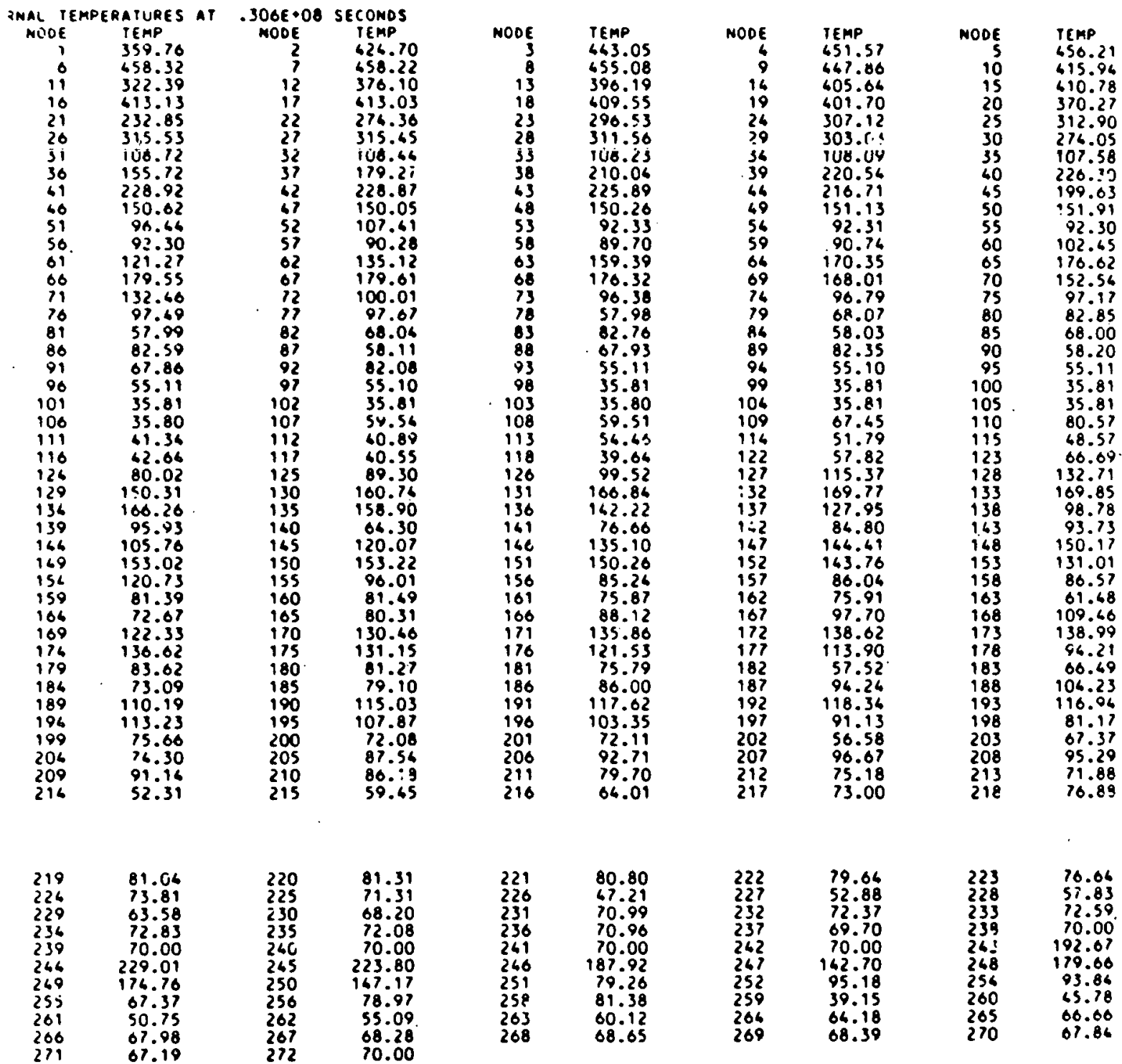




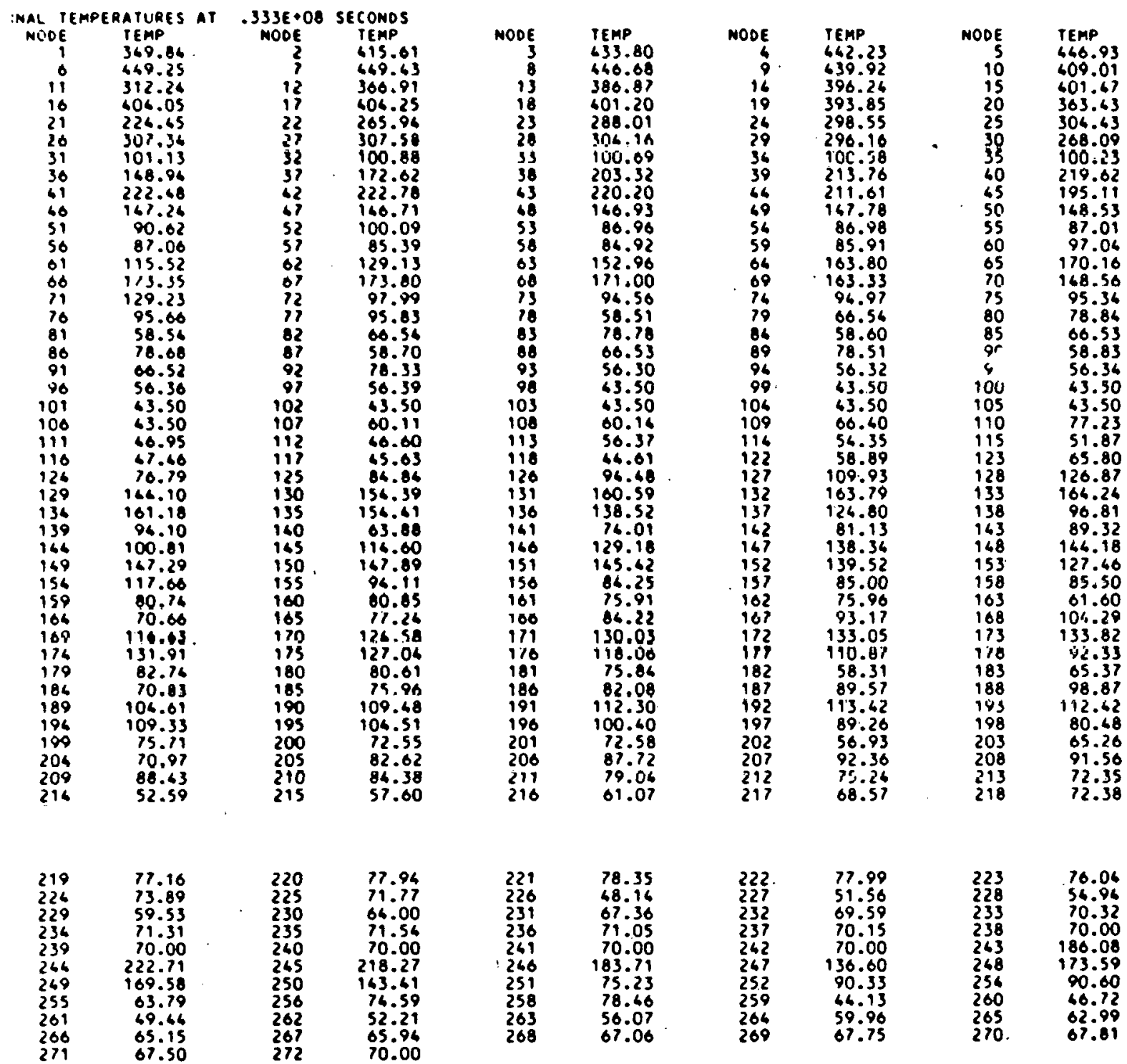


TAP-A OUTPUT (Cont'd)

Drywell 5 Predictions - March 1, 1980

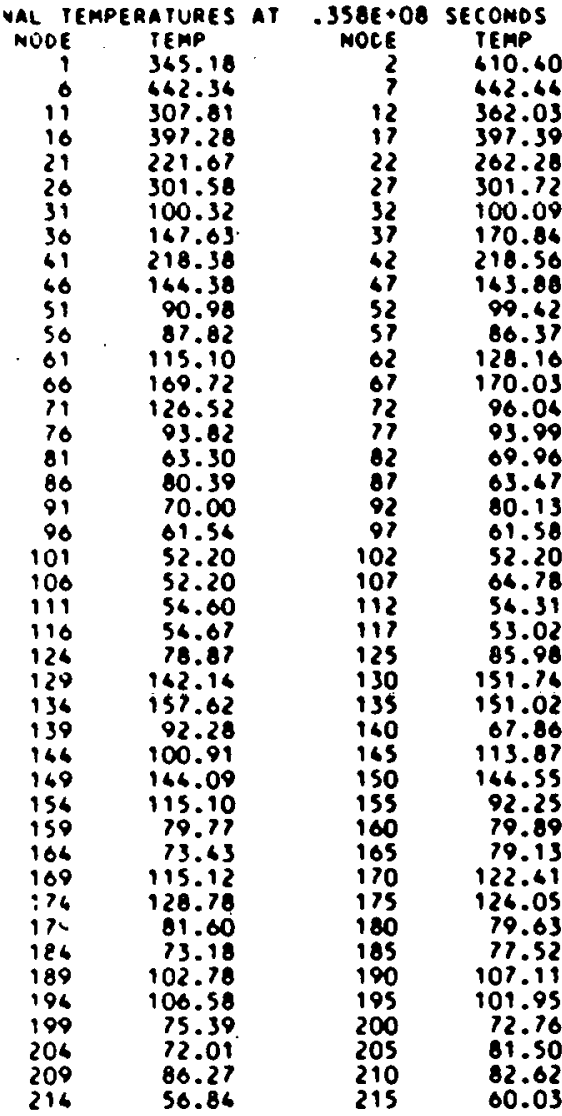
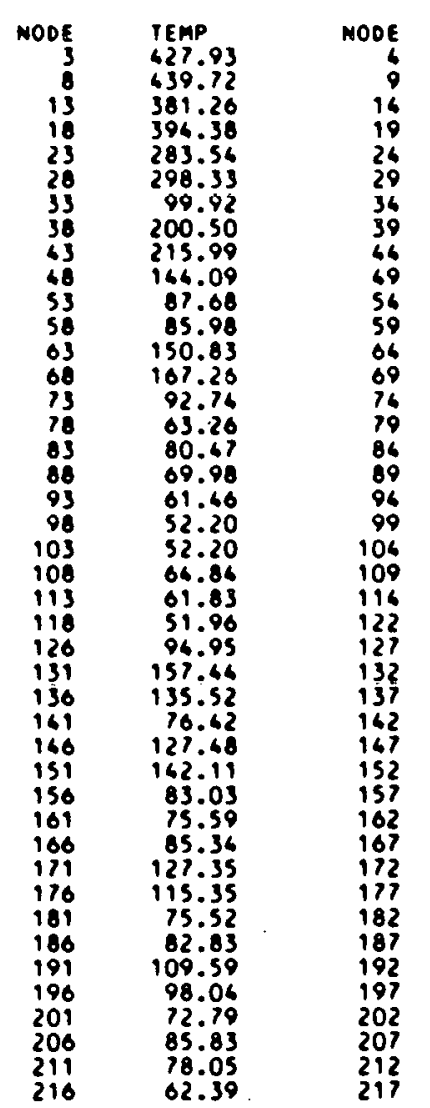

TEMP

435.88
433.13

390.09

387.19

293.48

290.69

99.82

210.35

207.56

146.91

87.70
86.87

86.87
$160 .+7$

160.77
159.17

93.16

09.95

63.36

80.26

61.68

52.20

52.20

60.21

03.86

109.70

160.32

122.16

82.68

135.96

136.37

83.75

75.66

93.53

130.06

108.39

63.01

89.63

87.5

01.21

89.85

74.92

67.82

$\begin{array}{rr}\text { NODE } & \text { TEMP } \\ 5 & 660.26 \\ 10 & 602.89 \\ 15 & 394.96 \\ 20 & 357.46 \\ 25 & 298.96 \\ 30 & 262.98 \\ 35 & 99.56 \\ 40 & 215.78 \\ 45 & 199.39 \\ 50 & 165.65 \\ 55 & 87.75 \\ 60 & 97.31 \\ 65 & 160.83 \\ 70 & 165.37 \\ 75 & 93.51 \\ 80 & 80.51 \\ 85 & 69.97 \\ 90 & 63.60 \\ 95 & 61.51 \\ 100 & 52.20 \\ 105 & 52.20 \\ 110 & 79.26 \\ 115 & 58.17 \\ 123 & 69.69 \\ 128 & 125.87 \\ 133 & 160.65 \\ 138 & 94.88 \\ 143 & 90.14 \\ 168 & 161.30 \\ 153 & 126.63 \\ 158 & 86.23 \\ 163 & 65.90 \\ 168 & 103.78 \\ 173 & 130.67 \\ 178 & 90.48 \\ 183 & 68.66 \\ 188 & 97.06 \\ 193 & 109.55 \\ 198 & 79.68 \\ 203 & 67.50 \\ 208 & 89.119 \\ 213 & 12.56 \\ 218 & 10.86 \\ & \end{array}$

$\begin{array}{lrrr}219 & 76.97 & 220 & 75.77 \\ 226 & 73.59 & 225 & 71.99 \\ 229 & 59.16 & 230 & 62.48 \\ 236 & 09.76 & 235 & 70.05 \\ 239 & 70.00 & 240 & 70.00 \\ 266 & 218.55 & 265 & 216.10 \\ 269 & 165.87 & 250 & 140.36 \\ 255 & 64.32 & 256 & 72.70 \\ 261 & 52.38 & 262 & 53.58 \\ 260 & 63.16 & 267 & 64.09 \\ 279 & 67.60 & 272 & 70.00\end{array}$

221
226
231
236
269
260
251
258
263
208

76.37
52.91
65.36
70.77
70.00
180.19
75.44
76.33
55.73
65.47

222
227
232
237
262
267
252
259
206
269
76.33
67.60
70.36
0.00
135.35
88.07
51.69
58.65
66.80

$\begin{array}{lr}223 & 75.09 \\ 228 & 58.28 \\ 233 & 88.69 \\ 238 & 70.00 \\ 263 & 183.97 \\ 268 & 169.91 \\ 256 & 88.23 \\ 260 & 51.51 \\ 265 & 60.99 \\ 270 & 67.64\end{array}$


TAP-A OUTPUT (Cont'd)

Drywell 5 Predictions - April 1, 1980

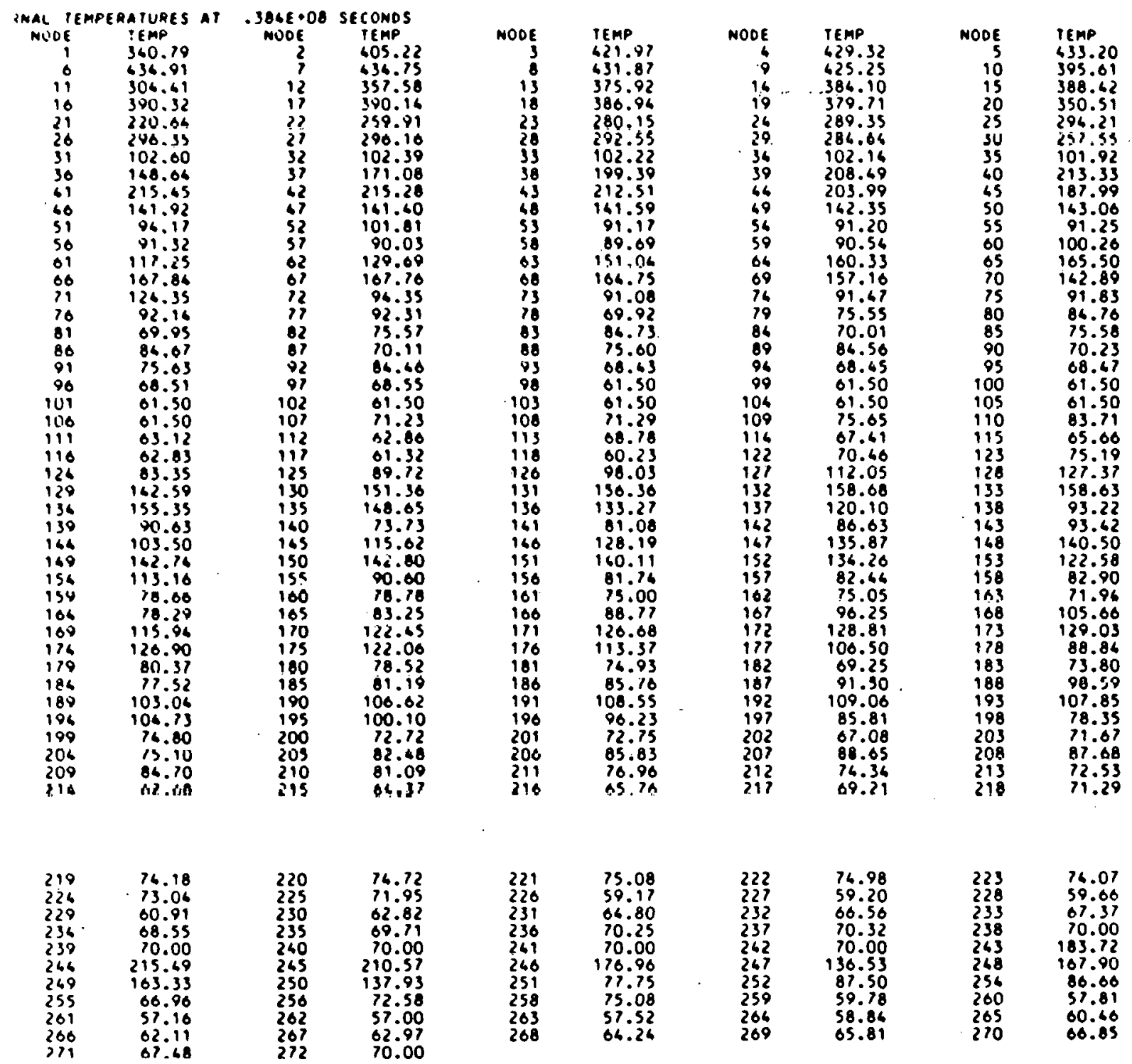


TAP-A OUTPUT (Cont'd)

Drywel1 5 Predictions - May 1, 1980

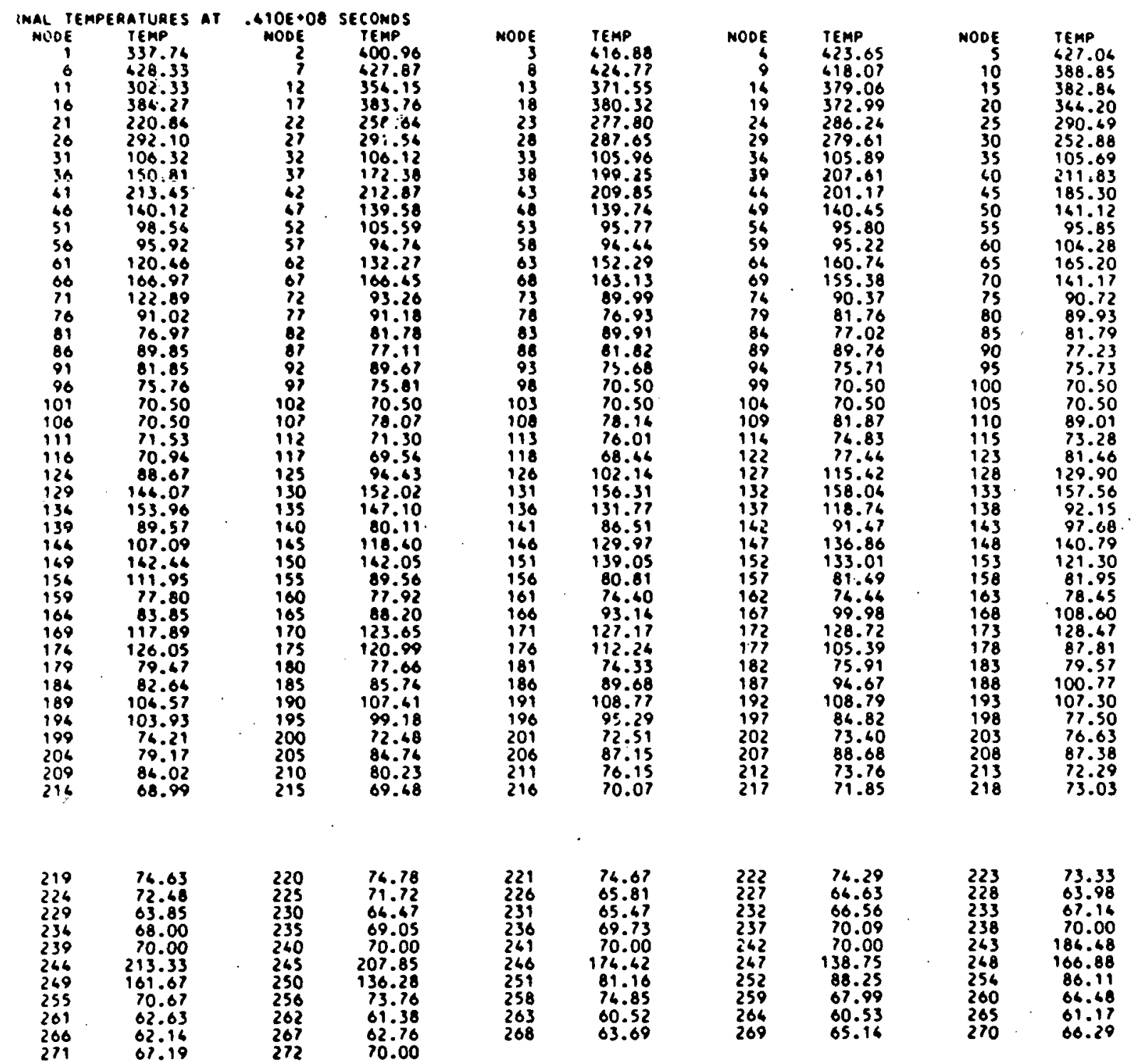


TAP-A OUTPUT (Cont'd)

Drywell 5 Predictions - June 1, 1980

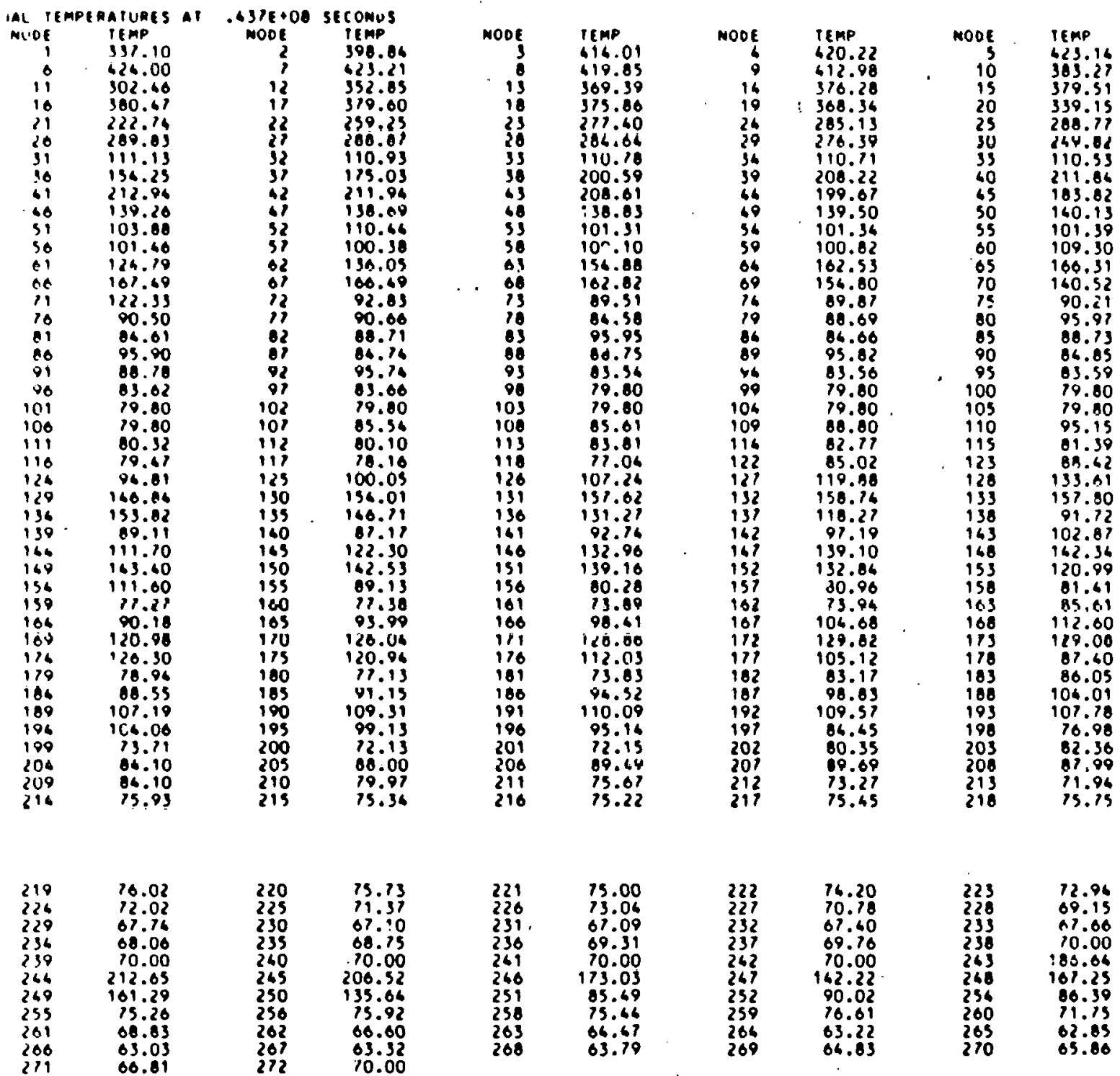


TAP-A OUTPUT (Cont'd)

Drywell 5 Predictions - July 1, 1980

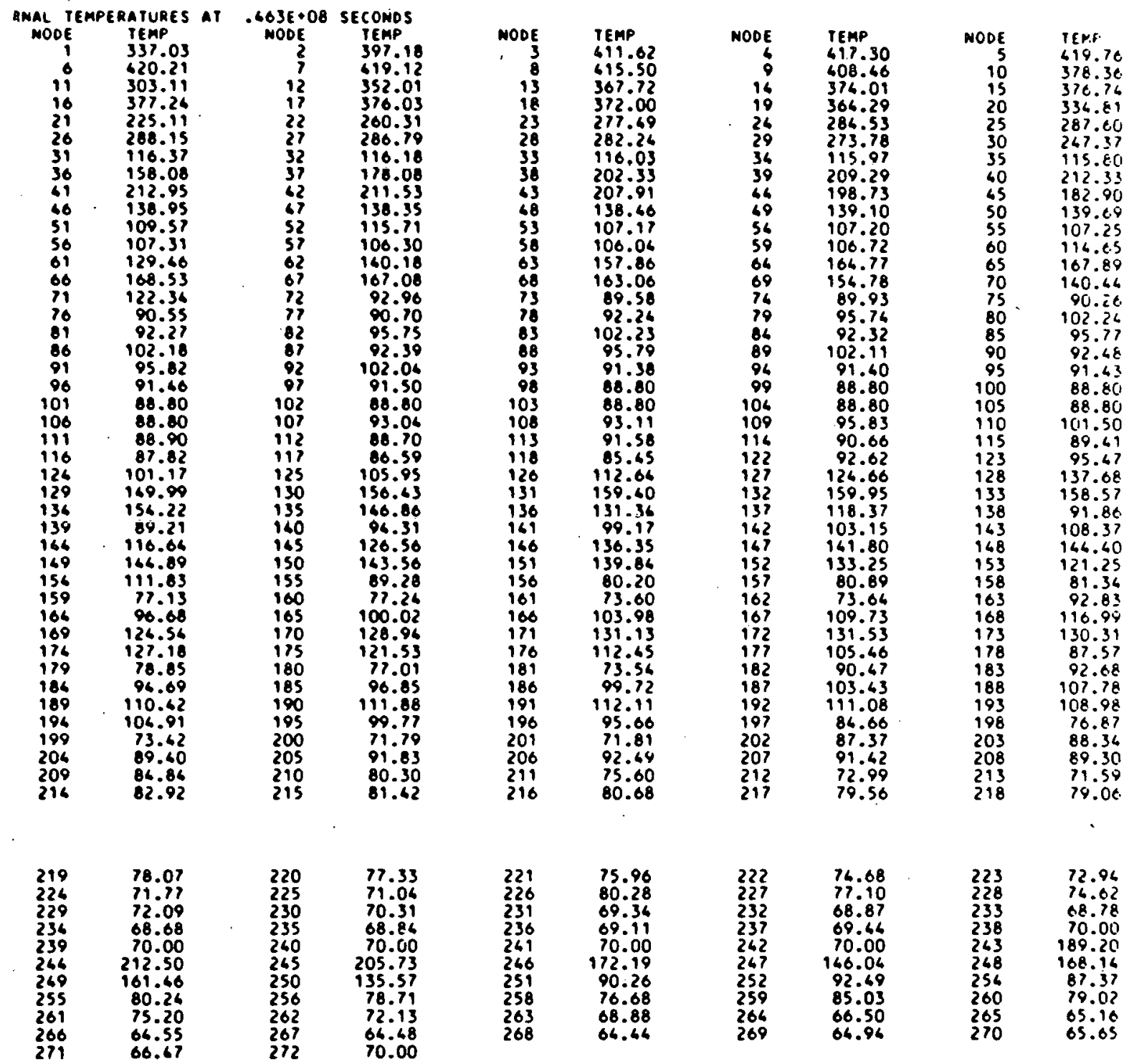


TAP-A OUTPUT (Cont'd)

Drywe11 5 Predictions - August 1, 1980

\begin{tabular}{|c|c|c|c|c|c|c|c|c|c|}
\hline 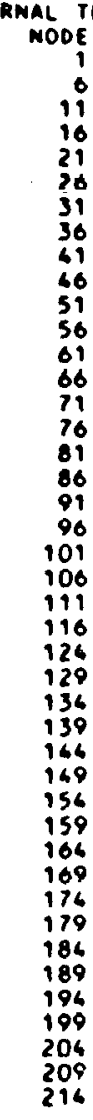 & $\begin{array}{l}\text { RATURES AT } \\
\text { TEMP } \\
330.08 \\
616.70 \\
303.48 \\
374.34 \\
227.16 \\
280.87 \\
121.50 \\
161.60 \\
213.38 \\
139.16 \\
116.69 \\
112.17 \\
133.58 \\
170.06 \\
122.89 \\
91.09 \\
95.49 \\
108.84 \\
99.76 \\
96.28 \\
88.20 \\
88.20 \\
89.63 \\
89.10 \\
103.57 \\
153.16 \\
155.18 \\
89.81 \\
120.86 \\
166.89 \\
112.82 \\
17.37 \\
100.72 \\
128.10 \\
128.84 \\
79.17 \\
98.73 \\
113.85 \\
106.33 \\
73.37 \\
93.58 \\
86.14 \\
86.52\end{array}$ & $\begin{array}{c}.490 E+08 \\
\text { MODE } \\
2 \\
7 \\
12 \\
17 \\
22 \\
27 \\
32 \\
37 \\
62 \\
67 \\
52 \\
57 \\
62 \\
67 \\
72 \\
77 \\
82 \\
87 \\
92 \\
97 \\
102 \\
107 \\
112 \\
117 \\
125 \\
130 \\
135 \\
160 \\
165 \\
150 \\
155 \\
160 \\
185 \\
170 \\
175 \\
180 \\
185 \\
190 \\
195 \\
200 \\
205 \\
210 \\
215\end{array}$ & $\begin{array}{c}\text { SECOMDS } \\
\text { TEMP } \\
395.30 \\
415.32 \\
350.96 \\
372.82 \\
261.16 \\
289.17 \\
121.31 \\
180.85 \\
211.59 \\
138.50 \\
120.80 \\
191.09 \\
163.96 \\
168.21 \\
93.60 \\
91.26 \\
99.81 \\
95.56 \\
106.62 \\
94.29 \\
88.20 \\
96.15 \\
89.38 \\
87.81 \\
110.58 \\
159.10 \\
167.59 \\
97.82 \\
130.46 \\
165.15 \\
89.93 \\
77.47 \\
106.26 \\
132.09 \\
122.70 \\
77.26 \\
101.06 \\
116.83 \\
100.99 \\
71.52 \\
95.70 \\
81.15 \\
85.65\end{array}$ & $\begin{array}{r}\text { NOOE } \\
3 \\
8 \\
13 \\
18 \\
23 \\
28 \\
33 \\
38 \\
43 \\
48 \\
53 \\
58 \\
63 \\
68 \\
13 \\
78 \\
83 \\
88 \\
93 \\
98 \\
103 \\
108 \\
113 \\
118 \\
126 \\
131 \\
136 \\
161 \\
166 \\
151 \\
156 \\
161 \\
160 \\
171 \\
176 \\
181 \\
186 \\
191 \\
196 \\
201 \\
206 \\
211 \\
216 \\
16\end{array}$ & $\begin{array}{l}\text { TEMP } \\
409.18 \\
411.45 \\
366.03 \\
368.51 \\
277.59 \\
280.10 \\
121.10 \\
206.10 \\
207.69 \\
138.59 \\
112.09 \\
110.80 \\
100.86 \\
163.86 \\
90.96 \\
95.68 \\
106.91 \\
99.78 \\
94.27 \\
88.20 \\
88.20 \\
96.15 \\
93.98 \\
96.79 \\
117.10 \\
169.58 \\
131.96 \\
103.40 \\
139.76 \\
161.09 \\
80.56 \\
73.55 \\
108.30 \\
133.79 \\
113.63 \\
73.48 \\
103.91 \\
114.63 \\
96.73 \\
71.54 \\
95.82 \\
75.92 \\
85.05\end{array}$ & $\begin{array}{r}\text { MOOE } \\
6 \\
9 \\
14 \\
19 \\
26 \\
79 \\
36 \\
39 \\
46 \\
69 \\
54 \\
59 \\
86 \\
69 \\
74 \\
79 \\
84 \\
89 \\
94 \\
99 \\
106 \\
109 \\
114 \\
122 \\
127 \\
132 \\
137 \\
142 \\
147 \\
152 \\
157 \\
162 \\
167 \\
172 \\
177 \\
182 \\
187 \\
192 \\
197 \\
202 \\
207 \\
212 \\
217\end{array}$ & $\begin{array}{r}\text { TEMP } \\
614.48 \\
404.24 \\
371.89 \\
360.62 \\
284.13 \\
271.46 \\
121.09 \\
210.57 \\
198.27 \\
139.19 \\
112.10 \\
111.60 \\
167.26 \\
155.33 \\
90.50 \\
99.82 \\
95.51 \\
106.76 \\
96.28 \\
88.20 \\
88.20 \\
99.59 \\
92.83 \\
95.63 \\
128.84 \\
161.65 \\
119.01 \\
107.56 \\
144.75 \\
134.23 \\
89.23 \\
73.59 \\
193.94 \\
133.74 \\
106.36 \\
93.55 \\
107.52 \\
113.15 \\
85.39 \\
90.75 \\
93.71 \\
72.96 \\
83.69\end{array}$ & $\begin{array}{r}\text { NOOE } \\
5 \\
10 \\
15 \\
20 \\
25 \\
30 \\
35 \\
60 \\
65 \\
50 \\
55 \\
60 \\
65 \\
70 \\
75 \\
80 \\
85 \\
90 \\
95 \\
100 \\
105 \\
110 \\
115 \\
123 \\
128 \\
133 \\
138 \\
143 \\
148 \\
153 \\
158 \\
163 \\
168 \\
173 \\
178 \\
183 \\
188 \\
193 \\
198 \\
203 \\
208 \\
213 \\
218\end{array}$ & $\begin{array}{r}1 E M . F \\
41 E .59 \\
313.89 \\
376.22 \\
330.89 \\
286.75 \\
325.401 \\
120.89 \\
293.17 \\
182.64 \\
139.75 \\
112.13 \\
119.23 \\
109.88 \\
160.92 \\
90.82 \\
106.95 \\
99.80 \\
95.61 \\
94.26 \\
88.26 \\
88.26 \\
105.92 \\
91.31 \\
99.18 \\
149.62 \\
159.88 \\
92.59 \\
112.78 \\
160.88 \\
122.08 \\
81.70 \\
96.16 \\
120.98 \\
132.10 \\
88.25 \\
96.65 \\
111.56 \\
110.76 \\
77.15 \\
92.60 \\
91.19 \\
71.33 \\
82.88\end{array}$ \\
\hline & & & & & & & & & \\
\hline $\begin{array}{l}219 \\
226 \\
229 \\
234 \\
239 \\
266 \\
269 \\
255 \\
261 \\
266 \\
271\end{array}$ & $\begin{array}{r}80.67 \\
71.70 \\
76.38 \\
69.81 \\
70.00 \\
212.78 \\
162.20 \\
86.38 \\
79.66 \\
66.65 \\
66.22\end{array}$ & $\begin{array}{l}220 \\
225 \\
230 \\
235 \\
240 \\
265 \\
250 \\
256 \\
262 \\
267 \\
272\end{array}$ & $\begin{array}{r}79.51 \\
70.79 \\
73.99 \\
69.31 \\
70.00 \\
205.63 \\
136.06 \\
81.96 \\
70.68 \\
66.22 \\
70.00\end{array}$ & $\begin{array}{l}221 \\
226 \\
231 \\
236 \\
261 \\
266 \\
251 \\
258 \\
263 \\
268\end{array}$ & $\begin{array}{r}77.47 \\
83.77 \\
72.16 \\
69.16 \\
70.00 \\
171.85 \\
94.60 \\
78.50 \\
73.26 \\
65.62\end{array}$ & $\begin{array}{l}222 \\
227 \\
232 \\
237 \\
262 \\
267 \\
252 \\
259 \\
266 \\
269\end{array}$ & $\begin{array}{r}75.07 \\
81 . .33 \\
70.91 \\
69.21 \\
70.00 \\
169.59 \\
95 . .62 \\
86.38 \\
70.17 \\
65.65\end{array}$ & $\begin{array}{l}223 \\
228 \\
233 \\
238 \\
263 \\
268 \\
256 \\
260 \\
265 \\
270\end{array}$ & $\begin{array}{r}73.39 \\
79.12 \\
71.45 \\
70.00 \\
191.56 \\
109.56 \\
88.96 \\
82.53 \\
88.09 \\
65.70\end{array}$ \\
\hline
\end{tabular}

